\author{
UNIVERSIDADE DE SÃO PAULO \\ ESCOLA DE COMUNICAÇÕES E ARTES \\ PROGRAMA DE PÓS-GRADUAÇÃO EM COMUNICAÇÃO
}

REBEKA FIGUEIREDO DA GUARDA

O self e suas autorrepresentações nas redes sociais digitais: um estudo de perfis profissionais a partir da semiótica 


\title{
O self e suas autorrepresentações nas redes sociais digitais: um estudo de perfis profissionais a partir da semiótica
}

\author{
Versão Original
}

Dissertação apresentada à Escola de Comunicações e Artes da Universidade de São Paulo para a obtenção do título de Mestre em Ciências da Comunicação.

Área de Concentração: Ciências da Comunicação.

Linha de Pesquisa: Comunicação, Redes e Linguagens: Objetos Teóricos e Empíricos.

Orientação: Prof. Dr. Anderson Vinícius Romanini. 
Autorizo a reprodução e divulgação total ou parcial deste trabalho, por qualquer meio convencional ou eletrônico, para fins de estudo e pesquisa, desde que citada a fonte.

Catalogação na Publicação

Serviço de Biblioteca e Documentação

Escola de Comunicações e Artes da Universidade de São Paulo

Dados inseridos pelo(a) autor(a)

Guarda, Rebeka Figueiredo da

O self e suas autorrepresentações nas redes sociais

digitais: um estudo de perfis profissionais a partir da

semiótica / Rebeka Figueiredo da Guarda ; orientador,

Anderson Vinícius Romanini. -- São Paulo, 2020.

175 p.: il.

Dissertação (Mestrado) - Programa de Pós-Graduação em

Ciências da Comunicação - Escola de Comunicações e Artes /

Universidade de São Paulo.

Bibliografia

Versão original

1. Semiótica 2. autorrepresentação 3. redes sociais

digitais 4. cibercultura I. Romanini, Anderson Vinícius II.

Título.

CDD 21.ed. - 302.2 
GUARDA, Rebeka Figueiredo da.

Título: O self e suas autorrepresentações nas redes sociais digitais: um estudo de perfis profissionais a partir da semiótica.

Dissertação apresentada à Escola de Comunicações e Artes da Universidade de São Paulo para obtenção do título de Mestre em Ciências da Comunicação, 2020.

Aprovado em:

Banca examinadora.

Prof. Dr. Anderson Vinícius Romanini, Orientador.

Instituição: Escola de Comunicações e Artes, Universidade de São Paulo

Julgamento:

Assinatura:

Prof(a) Dr.(a):

Instituição:

Julgamento:

Assinatura:

Prof(a) Dr.(a):

Instituição:

Julgamento:

Assinatura: 
À minha avó Aida (in memoriam), por todos os cheiros, sabores, afetos $e$ memórias que constituem o que sou hoje; e ao meu avô Manuel (in memoriam), que me ensinou os primeiros passos da pesquisa com suas enciclopédias. 


\section{Agradecimentos}

Ao meu orientador, professor Vinícius Romanini, pela confiança e por ter me guiado pelos caminhos às vezes complexos da Semiótica; agradeço pela oportunidade de desenvolver esta pesquisa e pelos desafios estimulantes durante a trajetória.

Ao meu companheiro, Rolando Barreto, por estar presente em todas as etapas da pesquisa e por ter me incentivado e apoiado nos momentos mais difíceis; por ouvir as minhas dúvidas e me ajudar a encontrar soluções viáveis. "¡Gracias a mi coach de tesis!"

Aos meus pais, Monica C. Figueiredo e João M. da Guarda, por me ensinarem o que não está nos livros; pelo apoio emocional para que eu chegasse até aqui e pela compreensão de minhas ausências.

Aos meus irmãos, Helen, Fabiano, Polyana, Nicole e João Victor, por todas as alegrias. E às minhas sobrinhas, Beatriz, Isabela, Maria Eduarda, Valentina e Margoth, que me inspiram diariamente a ser uma pessoa melhor.

Aos meus amigos Márcia Ohlson, Renata Lípia e Pedro Caldas, pela parceria e por terem compartilhado comigo a trajetória da pós-graduação, tornando-a mais leve e prazerosa. E aos colegas do Grupo de Estudos SemioData, pela troca de ideias enriquecedoras.

Às amigas Manuella Maia Ribeiro e Raquel Endalécio Martins, que me inspiraram a fazer o mestrado quando isso parecia apenas um sonho; e à minha amiga Jéssica Andrade, pelas conversas, risadas e pelas sessões de cinema memoráveis.

Aos meus colegas de redação pelo apoio, em especial ao amigo Eder Santos, que me ajudou com a arte das imagens deste trabalho.

À professora Cândida Almeida e ao professor Decio Ferreira Forni, pelas valiosas sugestões durante o exame de qualificação deste trabalho.

Aos professores e às professoras da Escola de Comunicações e Artes da USP, por todos os aprendizados, em especial à professora Roseli Fígaro, que esteve presente no início desta caminhada, quando me tornei aluna especial do PPGCOM, em 2017.

Aos funcionários e às funcionárias da ECA-USP, pela atenção e pelo cuidado.

À Universidade de São Paulo, pelo ambiente inspirador para a busca do conhecimento. 
Sobre esta primeira e, em certo sentido, única regra da razão, a de que para aprender você deve desejar aprender e com tal desejo não estar satisfeito com o que você já se inclina a pensar, segue-se um corolário que por si só merece ser inscrito em cada muro da cidade da

Filosofia: não bloquear o caminho da investigação. ${ }^{1}$ (PEIRCE, CP 1:135)

\footnotetext{
1 "Upon this first, and in one sense this sole, rule of reason, that in order to learn you must desire to learn, and in so desiring not be satisfied with what you already incline to think, there follows one corollary which itself deserves to be inscribed upon every wall of the city of philosophy: Do not block the way of inquiry." (PEIRCE, CP 1:135).
} 


\section{Resumo}

GUARDA, Rebeka Figueiredo da. O self e suas autorrepresentações nas redes sociais digitais: um estudo de perfis profissionais a partir da semiótica. $2020.175 \mathrm{f}$. Dissertação (Mestrado em Ciências da Comunicação) - Escola de Comunicações e Artes da Universidade de São Paulo, São Paulo, 2020.

Este trabalho investiga as autorrepresentações no ambiente digital com base na Semiótica de Charles Sanders Peirce, considerando-as como fenômeno comunicacional. Com o objetivo de compreender a emergência da subjetividade em perfis em redes sociais digitais, discutimos as categorias fenomenológicas peirceanas, o conceito de semiose e a centralidade da ação do signo no processo comunicacional. Também discorremos sobre a noção de self como entidade semiótica e agente comunicativo, reconhecendo as autorrepresentações como identidades do sujeito. Recorremos, ainda, a uma articulação teórica que engloba o debate da cibercultura, dos processos participativos, do contexto socioeconômico e dos mecanismos de bancos de dados e seleção algorítmica engendrados no ambiente digital. A partir de ferramentas teórico-metodológicas da Semiótica, realizamos uma análise qualitativa de autorrepresentações construídas em perfis profissionais de coaches de carreira na rede social Instagram. Para isso, detalhamos o funcionamento do Instagram e suas políticas de dados e de uso. Como parte dos resultados, concluímos que a geração e o compartilhamento de significados em perfis em redes sociais emergem de fluxos semióticos de distintas naturezas, que têm origem no entrelaçamento entre ações humanas e elementos não-humanos.

Palavras-chave: Semiótica Peirceana; autorrepresentação; redes sociais digitais; cibercultura; seleção algorítmica; Instagram. 


\begin{abstract}
GUARDA, Rebeka Figueiredo da. The self and its self-representations in digital social networks: a study of professional profiles based on semiotics. 2020. 175 f. Dissertação (Mestrado em Ciências da Comunicação) - Escola de Comunicações e Artes da Universidade de São Paulo, São Paulo, 2020.

This work investigates self-representations in the digital environment based on Charles Sanders Peirce's Semiotics, considering them as a communicational phenomenon. In order to understand the emergence of subjectivity in profiles on digital social networks, we discuss the Peircean phenomenological categories, the concept of semiosis and the centrality of sign-action in the communicational process. We also discuss the notion of self as a semiotic entity and communicative agent, recognizing self-representations as subject identities. We also resort to a theoretical articulation that encompasses the debate on cyberculture, participatory processes, the socioeconomic context and the mechanisms of databases and algorithmic selection engendered in the digital environment. Based on Semiotics theoretical-methodological tools, we performed a qualitative analysis of selfrepresentations built on professional profiles of career coaches on the social network Instagram. For this, we detail the operation of Instagram and its data and usage policies. As part of the results, we conclude that the generation and sharing of meanings in profiles on social networks emerge from semiotic flows of different natures, which originate in the intertwining between human actions and non-human elements.
\end{abstract}

Keywords: Peircean semiotics; self-representation; digital social networks; cyberculture; algorithmic selection; Instagram. 


\begin{abstract}
Abreviaturas
App $=$ aplicativo

$\mathrm{CP}=$ Collected Papers de Charles Sanders Peirce (seguido do número do volume e dos parágrafos).
\end{abstract}

MS e L = Manuscritos de Peirce editados por R. Robin (seguido do número do volume e dos parágrafos). 


\section{Lista de imagens}

Figura 1 - Perfil de Kevin Systrom em 2012 .......................................................... 87

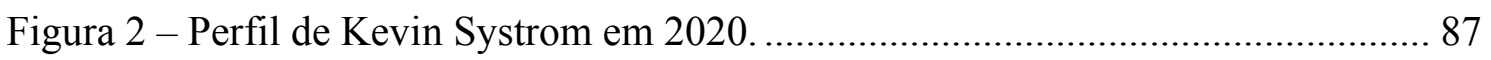

Figura 3 - perfil pessoal da pesquisadora no Instagram......................................... 93

Figura 4 - perfil profissional no Instagram. ........................................................... 95

Figura 5 - categorias do Instagram para perfis profissionais. ...................................... 96

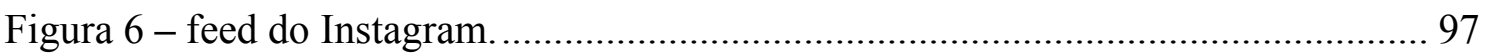

Figura 7 - exemplo de publicação no Story.................................................................. 98

Figura 8 - Outras formas de interação com postagens no feed..................................... 99

Figura 9 - exemplo de publicação paga no feed do Instagram. .................................. 100

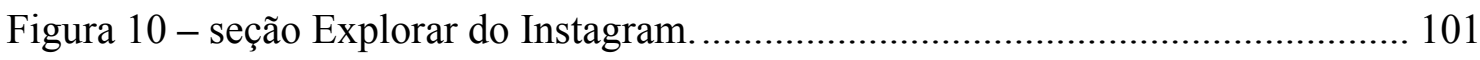

Figura 11 - pesquisa da palavra coach na ferramenta Explorar................................ 102

Figura 12 - primeira e segunda etapas de publicação no feed do Instagram. ............... 103

Figura 13 - terceira etapa de publicação no feed do Instagram. ................................... 104

Figura 14 - exemplo de publicação no Instagram.......................................................... 105

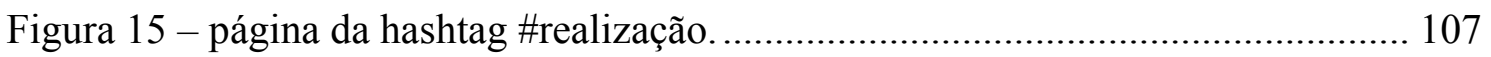

Figura 16 - publicação no feed a partir da hashtag \#realização................................... 107

Figura 17 - interface da ferramenta de busca Airsearch ........................................... 116

Figura 18 - Perfis profissionais de Ana (à esquerda) e de Bia (à direita) ................... 124

Figura 19 - Perfis profissionais de Ciro (à esquerda) e Duda (à direita) ...................... 124

Figura 20 - Perfis profissionais de Edi (à esquerda) e Fabi (à direita) ........................ 125

Figura 21 - árvore de links disponíveis nos perfis de Ana (à esq.) e de Fabi (à dir.)... 128

Figura 22 - fotografias do perfil de Ana no Instagram. ............................................ 130

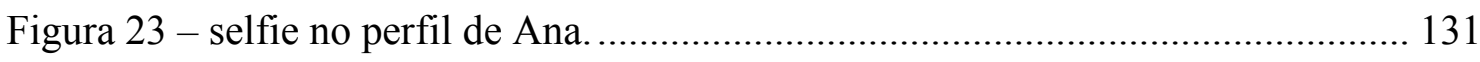

Figura 24 - postagem patrocinada feita pelo perfil de Ana........................................ 132

Figura 25 - anúncio originário de postagem patrocinada no perfil de Ana. ................ 132

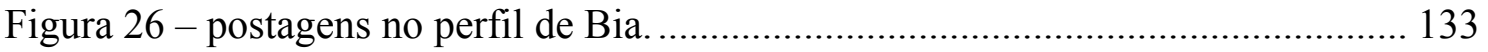

Figura 27 - postagem sobre livro no perfil de Bia, com legenda ao lado. .................... 134

Figura 28 - foto do feed de Ciro........................................................................... 135

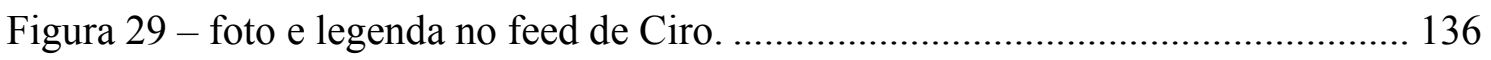

Figura 30 - publicação de Ciro com legenda e menção a outro perfil. ........................ 136

Figura 31 - foto de viagem no feed de Duda, com legenda. .................................... 137

Figura 32 - foto com legenda no feed de Duda..................................................... 138 
Figura 33 - fotografia de livro no feed de Edi. .......................................................... 139

Figura 34 - fotografia de Edi ao lado de duas pessoas............................................... 140

Figura 35 - fotografia de Edi com a companheira. .................................................. 140

Figura 36 - postagem patrocinada do perfil de Edi no feed do Instagram.................. 141

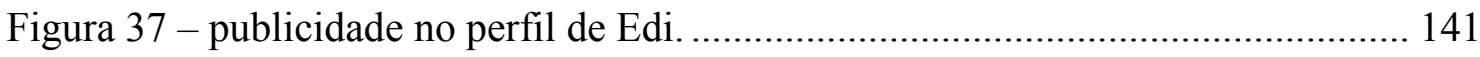

Figura 38 - fotografia de Fabi em viagem internacional......................................... 142

Figura 39 - fotografia de Fabi com livro nas mãos, com legenda............................... 143

Figura 40 - imagem no feed de Fabi..................................................................... 143

Figura 41 - imagens mostram coaches em palestras................................................ 145

Figura 42 - postagens sobre trabalho com notebooks................................................ 146

Figura 43 - publicação em perfil verificado mostra figuras de foguete e alvo. ........... 148

Figura 44 - publicação com legenda que usa emoji "no alvo". .................................. 149

Figura 45 - capa de livro best seller com figura de alvo.......................................... 149

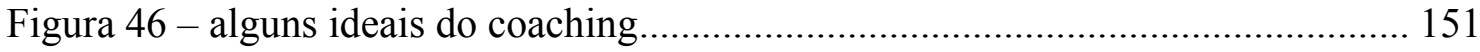

Figura 47 - publicação sobre autorresponsabilidade................................................ 151 


\section{Lista de quadros}

Tabela 1 - algumas informações dos perfis profissionais analisados. 


\section{SUMÁRIO}

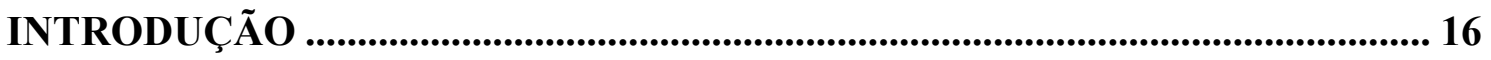

1. UM MAPA PARA O ESTUDO DAS AUTORREPRESENTAÇÕES.................. 25

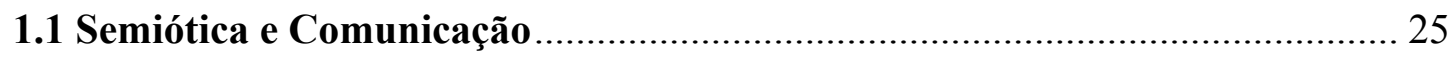

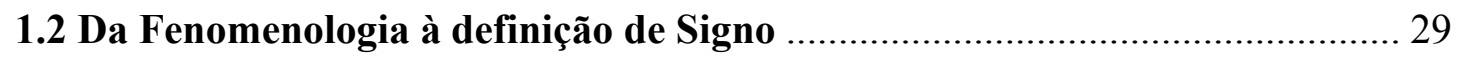

1.3 Semiose como centro do processo comunicacional ....................................... 34

1.4 Os signos e seus aspectos icônicos, indiciais e simbólicos .............................. 42

1.5 A arquitetura filosófica peirceana e suas implicações para a Semiótica ....... 45

1.6 O self é um signo: a subjetividade à luz da Semiótica ................................... 52

2. O SELF NO AMBIENTE DIGITAL: AUTORREPRESENTAÇÕES NO CONTEXTO CONTEMPORÂNEO .......................................................................65

2.1 Digitalização: banco de dados, algoritmos e rede ............................................. 65

2.2 Impactos do sistema econômico nas autorrepresentações ............................. 74

2.3 O self e os processos participativos no digital .................................................... 79

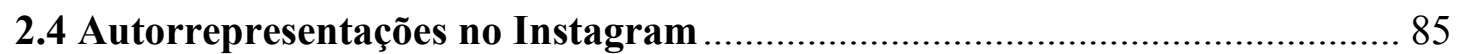

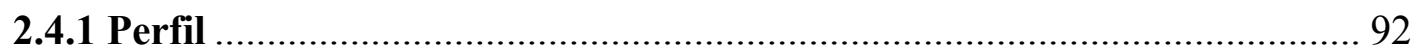

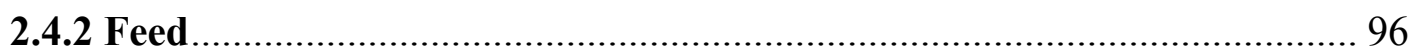

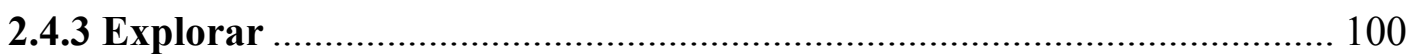

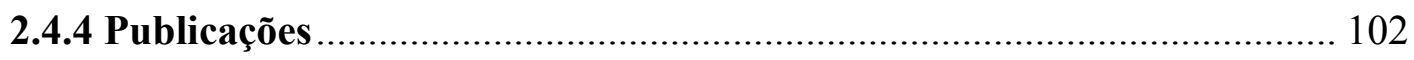

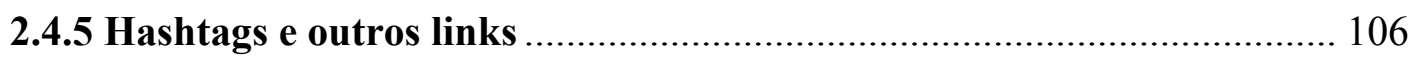

3. UM ESTUDO DAS AUTORREPRESENTAÇÕES DE COACHES DE

CARREIRA NO INSTAGRAM.......................................................................... 109

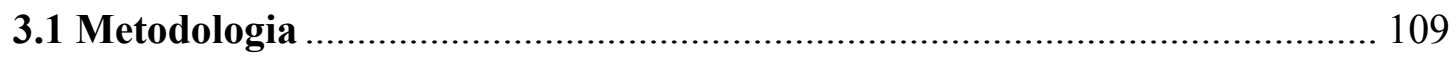

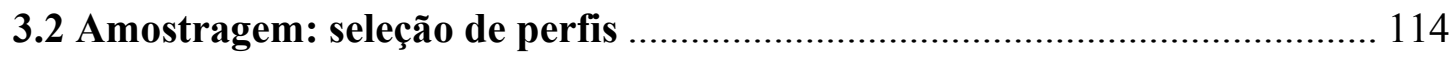

3.3 Coaching e coaches de carreira: experiência colateral ................................. 118

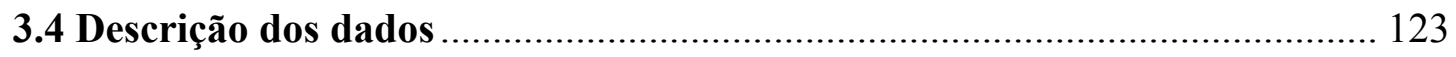

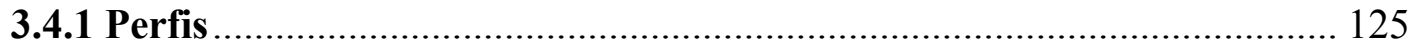

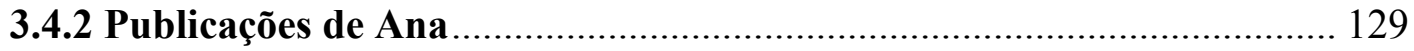

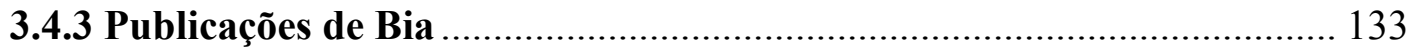

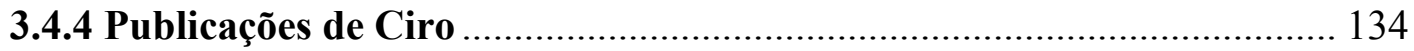

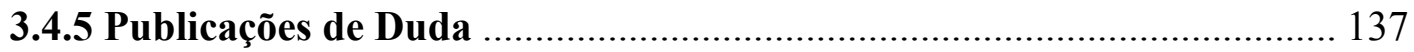

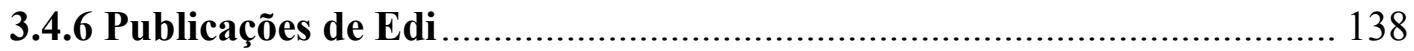

3.4.7 Publicações de Fabi ................................................................................... 142

3.5 Análise semiótica das autorrepresentações em perfis profissionais ............. 144

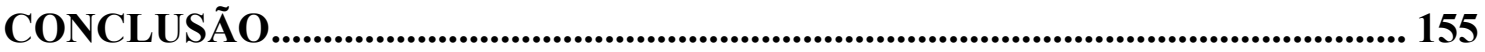


REFERÊNCIAS .

160

APÊNDICE A - Vincent Colapietro e a abordagem semiótica da subjetividade. 168

APÊNDICE B - Tabela geral de perfis de coaches 173 


\section{INTRODUÇÃO}

À medida em que os processos de sociabilidade passam pela digitalização e pela inserção na web, o estudo das representações da subjetividade no ambiente digital tornase crucial para a compreensão da Comunicação na contemporaneidade. ${ }^{2}$ Para se ter uma ideia da importância das interações realizadas virtualmente, destacamos que no fim de 2019 mais de 53\% da população mundial, o equivalente a 4,1 bilhões de pessoas, estava conectada à internet, segundo estimativas da União Internacional de Telecomunicações, agência da Organização das Nações Unidas. ${ }^{3}$ No Brasil, 74\% da população com 10 anos ou mais tem conexão à internet, de acordo com dados de 2019 da pesquisa TIC Domicílios, feita anualmente pelo Centro Regional de Estudos para o Desenvolvimento da Sociedade da Informação. ${ }^{4}$ Ainda segundo esse estudo, as atividades mais comuns durante o uso da internet no país são o envio de mensagens instantâneas (92\%), seguido pelo uso de redes sociais $(76 \%)$ e chamadas por voz ou vídeo $(73 \%)$; o equipamento preferido por $99 \%$ dos usuários para o acesso à internet é o celular.

Hoje, diversas atividades podem ser feitas virtualmente, tais como reservas em hotéis, compras, entrevistas de emprego, aulas, busca por parceiros amorosos, teletrabalho, reuniões e conferências. Sem a presença física, as interações nos espaços virtuais costumam ocorrer por meio de representações dos participantes, que podem variar de acordo com o ambiente e o propósito relacionado a tal representação. Em sites de compras, por exemplo, o cadastro do cliente, com dados como nome e endereço, pode funcionar como representação do usuário naquele ambiente. Já em redes sociais digitais, os sujeitos criam deliberadamente autorrepresentações mais sofisticadas, que podem incluir informações sensíveis, como preferências políticas e religiosas, além de fotos, vídeos e textos. Há ainda as representações que são geradas por sites, muitas vezes sem o conhecimento dos usuários, com base na coleta e no cruzamento de dados de navegação e outras informações fornecidas involuntariamente.

\footnotetext{
${ }^{2}$ Os termos web e internet não são sinônimos. Esclarecemos que a internet é a estrutura ou rede que conecta computadores ao redor do mundo e provê serviços como e-mail e armazenamento de arquivos online ou em nuvem, entre outros. Já o termo web, relacionado à World Wide Web, inventada por Tim Berners-Lee, designa um dos caminhos por meio dos quais é possível acessar a internet. A web funciona a partir de protocolos e depende de navegadores (browsers) para a transferência e a visualização de informações. Mais informações em: < https://www.w3.org/People/Berners-Lee/\#Bio>. Acesso em: 19 jun. 2020.

${ }^{3}$ Fonte: $<$ https://www.itu.int/en/ITU-D/Statistics/Pages/stat/default.aspx> $>$. Acesso em: 19 abr. 2020.

${ }^{4}$ Fonte: $<$ https://cetic.br/pt/noticia/tres-em-cada-quatro-brasileiros-ja-utilizam-a-internet-aponta-pesquisatic-domicilios-2019/>. Acesso em: 19 jun. 2020.
} 
Independentemente das características que as representações da subjetividade possam assumir, entendemos que elas são fundamentais para as trocas comunicacionais que ocorrem no ambiente digital e que se expandem para além do virtual à medida em que os limites entre on-line e off-line se desfazem. Diante da impossibilidade de pesquisar o tema de forma tão ampla, nossa pesquisa concentra-se nas autorrepresentações construídas voluntariamente pelos sujeitos por meio de perfis profissionais na rede social Instagram.

Antes de abordarmos a autorrepresentação do ponto de vista comunicacional, entretanto, cabe pontuar que este não é um fenômeno novo. Há inúmeros estudos em Antropologia e Psicologia que comprovam a natureza autorrepresentativa, narrativa e social do ser humano. Um exemplo é a pesquisa apresentada na obra $A$ Representação do Eu na Vida Cotidiana, na qual Goffman (2002) argumenta, em perspectiva sociológica, que os sujeitos gerenciam a apresentação do eu de acordo com contextos específicos e pactos estabelecidos previamente. Para o referido autor, a representação do eu, enquanto processo interativo, seria moldada de acordo com cada situação do cotidiano e com as expectativas dos envolvidos, como se os sujeitos atuassem em um palco teatral. O estudo de Goffman foi realizado na década de 1950, a partir de pesquisa etnográfica baseada em interações face a face.

Inspirada pelo trabalho de Goffman (2002) e com foco na arquitetura dos ambientes digitais, boyd (2002) analisa o gerenciamento de perfis como identidades online e afirma que o digital promove o que ela chama de "colapso contextual", pois as interações antes efêmeras entre os sujeitos passam a ser armazenadas em dados padronizados, que se tornam perenes e podem ser usados em distintos contextos. ${ }^{5}$ Nessa perspectiva, a autora alerta para a dificuldade que os usuários têm de controlar suas representações digitais e sugere mecanismos de conscientização dos sujeitos e abordagens de design que permitam o gerenciamento dessas representações.

Ao considerarmos as possibilidades de representação e sociabilização propiciadas pelas redes digitais, entendemos que a constituição das autorrepresentações ganha novas camadas de complexidade. É importante pontuar que a forma como nos autorrepresentamos é o resultado abstrativo de uma complexa rede de relações que mantemos com o mundo ao nosso redor. Nesse sentido, as autorrepresentações não estão

\footnotetext{
${ }^{5}$ A pesquisadora danah michele boyd retirou as letras maiúsculas de seu nome e solicita que ele seja escrito sempre em letras minúsculas. Mais informações em: $<$ https://www.danah.org/name.html $>$. Acesso em: 13 abr. 2019.
} 
relacionadas somente às escolhas dos sujeitos que se autorrepresentam, mas a um conjunto de fatores que pode incluir, quando se trata de ambientes digitais, a participação de outros usuários, as interfaces e suas dinâmicas, a codificação dos dados digitalizados, as programações algorítmicas, as políticas da rede e o contexto socioeconômico, entre outros. Além disso, as representações do eu não são estáticas. Assim como as autorrepresentações nas interações face a face são múltiplas e podem se transformar de acordo com o contexto, o movimento e a mudança também são características intrínsecas ao universo digital.

Em sites de redes sociais ${ }^{6}$ como o Facebook, por exemplo, a autorrepresentação de um sujeito pode ser observada com mais clareza nas escolhas feitas em seu perfil, tais como as imagens selecionadas e as descrições que o usuário faz sobre si mesmo, mas ela não se encerra aí. As curtidas, os comentários e o compartilhamento de conteúdos também ajudam a compor essa representação, e há diversos fatores que podem interferir nesse processo. Em outras palavras, as autorrepresentações são construídas a partir do entrelaçamento entre signos de distintas naturezas. Nessa perspectiva, o fenômeno da autorrepresentação não pode ser abordado apenas do ponto de vista do discurso ou da imagem, uma vez que ele se inicia na própria constituição do eu e se desenvolve de forma dinâmica e contínua a partir das experiências do sujeito no mundo.

Diante de tais desafios, propomos nesta dissertação o estudo das autorrepresentações no ambiente digital enquanto processos comunicacionais com base na Semiótica desenvolvida pelo filósofo, lógico e matemático norte-americano Charles Sanders Peirce (1839-1914). De forma resumida, a pergunta que nos propomos a responder com esta pesquisa é: de que modo a Semiótica de Charles S. Peirce pode contribuir para o estudo dos processos de autorrepresentação e de geração e circulação de significados em perfis profissionais criados em redes sociais digitais?

Desse modo, interessa-nos contribuir para o avanço de uma abordagem epistemológica e metodológica capaz de alcançar os distintos aspectos envolvidos na emergência das subjetividades em espaços virtuais.

\footnotetext{
${ }^{6}$ No seminal artigo Social Network Sites: Definition, History, and Scholarship, boyd e Ellison (2007, p.211, tradução nossa) definem os sites de redes sociais (social network sites - SNS) como serviços em que é possível: “(1) construir um perfil público ou semipúblico dentro de um sistema delimitado, (2) articular uma lista de outros usuários com quem eles compartilham uma conexão e (3) visualizar e percorrer sua lista de conexões e aquelas feitas por outras pessoas dentro do sistema." Segundo as autoras, esses sites funcionariam principalmente para colocar em contato pessoas que já fazem parte de uma rede social fora da Internet. Hoje, entretanto, observamos que as conexões nessas redes sociais ocorrem por afinidades de temas e outros propósitos, e não necessariamente por relacionamentos anteriores, em um processo que vem acompanhando os novos usos e funcionalidades desses serviços.
} 
Entendemos que a Semiótica oferece o arcabouço teórico-metodológico adequado ao estudo do fenômeno das autorrepresentações, uma vez que esta é uma teoria geral sobre as formas como representamos e interpretamos a realidade, conforme pontua Santaella (1994). Adicionalmente, assinalamos que esta pesquisa abarca outros pontos importantes da arquitetura filosófica peirceana, tais como a Fenomenologia e a Metafísica, pois entendemos que as inter-relações entre os conceitos desenvolvidos por Peirce ao longo de sua trajetória são essenciais para a compreensão da Semiótica entendida como lógica geral dos processos de significação. Assim, em vez de realizar uma taxonomia dos signos ou tentar encaixar o objeto em categorias rígidas, nosso objetivo é discutir as contribuições da Semiótica no estudo dos processos comunicacionais relacionados à autorrepresentação em ambientes digitais.

Entre os objetivos específicos estão: 1) discutir os conceitos de subjetividade e de autorrepresentação à luz da Semiótica Peirceana; 2) distinguir de que maneira as dinâmicas e o funcionamento de redes sociais digitais impactam as autorrepresentações e representações da subjetividade; 3) identificar os processos semióticos envolvidos na criação e circulação de sentidos no ambiente digital, especialmente aqueles relacionados às autorrepresentações de profissionais em redes sociais; 4) contribuir, a partir dos aportes da arquitetura filosófica peirceana, para o avanço das reflexões epistemológica e metodológica na abordagem do fenômeno das autorrepresentações em ambientes digitais.

O recorte do tema foi feito a partir de perfis profissionais criados no Instagram, rede social lançada em 2010, comprada pelo Facebook em 2012 e que hoje tem mais de um bilhão de usuários ativos em todo o mundo. ${ }^{7} \mathrm{~A}$ opção pela análise de autorrepresentações no Instagram considerou a relevância que as redes sociais digitais conquistaram nos últimos anos, à medida em que deixaram de ser apenas espaços para manter contato com amigos e familiares e incorporaram atividades como venda de produtos e serviços, busca por trabalho e recrutamento de profissionais. ${ }^{8}$

Outrossim, a preferência pelo Instagram em detrimento de outros serviços, como o Facebook ou o LinkedIn, foi baseada na popularidade que a rede tem entre os brasileiros e nas possibilidades de uso dela, que vem sendo adotada na divulgação de produtos e

\footnotetext{
${ }^{7}$ Informações disponíveis em: < https://instagram-press.com/our-story/>. Acesso em: 16 mar 2019.

${ }^{8}$ Nesta dissertação, consideramos o Instagram uma rede social digital e pontuamos que, diferentemente dos primeiros sites de redes sociais, como o Orkut e o Facebook, o Instagram surgiu como aplicativo para smartphone, criado para a linguagem do sistema operacional iOS. Ao longo do texto, referimo-nos ao Instagram como rede social digital, aplicativo, rede social e, em alguns casos, plataforma. Entretanto, prevalece a noção de rede social enquanto espaço digital de trocas comunicacionais entre sujeitos.
} 
serviços de diferentes áreas. Nesse sentido, o Instagram vem lançando ferramentas que facilitam anúncios e a compra e venda de produtos e serviços, além da possibilidade de gerenciar métricas e desempenho do perfil, em um movimento que parece estimular a integração entre a vida pessoal e profissional. ${ }^{9}$

O Brasil tem a segunda maior base de usuários no Instagram, contabilizando pelo menos 57 milhões de usuários ativos mensais, atrás apenas dos Estados Unidos, segundo o levantamento Digital in 2018. ${ }^{10}$ Dado semelhante havia sido divulgado em 2017 pelo diretor de negócios global do Instagram, Vishal Shah, que, em visita ao Brasil, afirmou que a rede contava com mais de 50 milhões de usuários brasileiros ativos mensais, número que já garantia ao país a segunda posição em participação no Instagram. ${ }^{11}$

Já a escolha de perfis profissionais - e não perfis pessoais - foi feita porque acreditamos que as autorrepresentações teriam uma intenção clara, qual seja, criar uma autoimagem profissional positiva dentro do contexto do atual sistema econômico, de modo a gerar efeitos ou ganhos tais como o fortalecimento da própria imagem enquanto marca, um aumento salarial, um novo cargo, a venda de um serviço ou uma vaga de trabalho, entre outros. Ou seja, entendemos que pessoas que criam perfis em redes sociais para destacar suas qualidades profissionais supostamente estariam em busca de algum tipo de vantagem na carreira. Nesse sentido, nossa investigação pode orientar-se pelo contexto em que tais autorrepresentações se inserem e pelos possíveis efeitos gerados por elas.

Dentre inúmeros tipos de atividades profissionais que poderiam ser escolhidas para a observação de autorrepresentações, optamos por selecionar perfis de pessoas que se autodenominavam "coaches de carreira" no momento da coleta de dados, feita em 2019, na medida em que essa atividade permitiria a avaliação de diferentes estratégias usadas na construção de uma autorrepresentação voltada ao destaque de atributos profissionais. Cabe assinalar que a profissão coach (do inglês treinador) não tem regulamentação do governo brasileiro e a formação é feita por meio de cursos livres que podem ter duração e metodologias variadas. Acreditamos que a não-regulamentação pode

\footnotetext{
${ }^{9} \mathrm{O}$ Instagram tem uma página exclusiva para negócios, chamada Instagram Business, na qual compartilha sugestões de boas práticas na rede voltadas para pequenas, médias e grandes empresas. Disponível em: <https://business.instagram.com/>. Acesso em: 20 mai. 2020.

${ }^{10}$ A "2018 Global Digital" ou simplesmente "Digital in 2018" é uma pesquisa realizada pela empresa de gerenciamento de mídias sociais Hootsuite e pela agência de criação de conteúdo We Are Social. O estudo inclui dados de mais de 239 países e territórios sobre hábitos relacionados ao uso de internet e redes sociais. Disponível em: < https://hootsuite.com/pt/pages/digital-in-2018>. Acesso em: 10 fev. 2019. ${ }^{11}$ Disponível em: < https://www1.folha.uol.com.br/mercado/2017/10/1931057-com-50-milhoes-deusuarios-brasil-e-segundo-no-ranking-do-instagram.shtml >. Acesso em: 13 abr. 2019.
} 
levar a um esforço maior na construção da autorrepresentação dessas pessoas, pois elas precisariam encontrar maneiras de validar socialmente sua atividade profissional sem recorrer, por exemplo, a títulos acadêmicos. A escolha também está relacionada ao contato prévio que a pesquisadora teve com profissionais desta área, durante o exercício do Jornalismo. Contudo, mais do que fazer uma análise exaustiva desses perfis, o recorte proposto tem como objetivo permitir a demonstração e a validação das teorias debatidas ao longo da dissertação. Outrossim, ponderamos que esta pesquisa não tem a pretensão de discutir ou fazer valorações sobre a atividade de coaching.

Nosso interesse pelo modo como as pessoas se autorrepresentam em redes sociais digitais foi despertado em 2016. Nessa época, passamos a observar com crescente curiosidade as autoimagens criadas por ex-colegas de trabalho em perfis no LinkedIn, rede social que se autodenomina "a maior rede profissional do mundo". ${ }^{12}$ De modo geral, os perfis criados nessa rede são orientados pela intenção de comunicar as habilidades e os resultados conquistados ao longo da carreira dos usuários. No início, o que mais nos chamava a atenção era que algumas das autorrepresentações pareciam muito distintas da experiência cotidiana. Em outras palavras, era como se houvesse duas pessoas, uma dentro e outra fora do ambiente digital. Essa observação nos levou a alguns questionamentos, tais como: quais são as diferenças e as semelhanças entre o eu dentro e fora da internet? O sujeito autorrepresentado em uma rede social digital é o mesmo daquele sem a mediação do espaço virtual? De que modo as autorrepresentações no ambiente digital impactam as experiências do sujeito, e vice-versa? Essas perguntas também nos ajudaram a investigar o tema e ao longo da dissertação buscaremos respondêlas.

A observação das autorrepresentações feitas em perfis no Instagram, a exploração dos recursos disponíveis na rede a partir do uso cotidiano da mesma e a revisão bibliográfica nos levaram à hipótese de que as tecnologias e o ambiente digital amplificam e fornecem novas camadas de complexidade aos processos de autorrepresentação e criação e compartilhamento de sentidos, uma vez que as autorrepresentações passam a ser atravessadas por mais variáveis, tais como signos de distintas naturezas, a aceleração do tempo, a perenidade de algumas trocas comunicacionais nesses espaços e as dinâmicas orientadas pela rede por meio de interfaces, codificações e algoritmos, entre outras.

\footnotetext{
${ }^{12}$ Disponível em: <https://news.linkedin.com/about-us\#statistics>. Acesso em: 01 jul. 2018.
} 
Dessa forma, admitem-se as seguintes hipóteses secundárias: os sujeitos têm controle limitado sobre suas autorrepresentações no ambiente digital, embora aqueles que conheçam as políticas e o funcionamento da rede possam direcionar suas intenções de forma mais assertiva e conquistar os propósitos previstos com a construção da autoimagem; a autorrepresentação no ambiente digital depende da adaptação constante do usuário às dinâmicas desse espaço e de negociações entre os sujeitos envolvidos nas interações; a tentativa de enquadrar a subjetividade a tipos e às lógicas da rede pode aumentar a tendência à padronização de perfis, levando essas autorrepresentações a se distanciarem das características do sujeito autorrepresentado; a inclusão de dados pessoais em redes sociais e sites com o objetivo de construir perfis profissionais pode levar os sujeitos a experimentar o efeito oposto ao esperado com a autorrepresentação, na medida em que essas qualidades pessoais codificadas em dados passam a pertencer à rede, que pode recombiná-los e inseri-los em outros contextos, gerando significados imprevisíveis.

Nossa pesquisa possui uma abordagem representacional e tem a Semiótica de Peirce (2017) como sua principal base teórica. Para verificar se as questões propostas neste trabalho estavam sendo discutidas em outras produções nacionais, realizamos um levantamento dos termos "autorrepresentação", "representação", "self", "eu", "Semiótica", "redes sociais digitais", "ambientes digitais" e "Instagram" nos principais bancos de teses e dissertações do Brasil. ${ }^{13}$ Entre os resultados para "autorrepresentação" e "Instagram", encontramos a dissertação de Fantoni (2017), que trata dos processos de autorrepresentação no Instagram de jovens de Porto Alegre, com foco na discussão sobre juventude e nas questões de mobilidade suscitadas por aplicativos como o do Instagram. Nesse caso, as autorrepresentações são investigadas a partir do enfoque das práticas ciberculturais juvenis e, portanto, tal dissertação difere de nossa proposta. Lima (2009), por sua vez, discute as autorrepresentações de travestis no Orkut do ponto de vista da visualidade, de modo distinto de nossa pesquisa.

Do ponto de vista do self, encontramos a tese de Garra (2006) sobre o self semiótico e o desenvolvimento da identidade. Embora a autora recorra, como em nosso caso, ao conceito de self em Peirce, sua pesquisa está centrada no campo da Psicologia.

\footnotetext{
${ }^{13}$ Realizamos buscas dos termos citados no Catálogo de Teses e Dissertações da Capes e em bancos de teses e dissertações das principais universidades públicas e privadas do Brasil. Usamos também o buscador Google Acadêmico. Durante a pesquisa, priorizamos os bancos de programas de pós-graduação em Comunicação, embora tenhamos considerado pesquisas de outros campos. A busca dos termos foi feita considerando título, palavras-chave e resumo dos trabalhos.
} 
Do mesmo modo, é importante destacar que nossa dissertação se afasta da abordagem de Bessa (2018), que discute a emergência do fenômeno de influenciadores digitais a partir da análise de ambiente, características e funcionalidades do Instagram. Nossa perspectiva também é diferente da proposta de Karhawi (2018), que realiza a caracterização de um novo perfil profissional no campo da Comunicação à luz dos estudos da Arqueologia da Mídia.

Para atingir os objetivos propostos, dividimos esta dissertação em três capítulos, além da introdução e da conclusão. O primeiro capítulo está dedicado à discussão da Semiótica do ponto de vista comunicacional. Por meio de um percurso pelos principais pontos da arquitetura filosófica peirceana, buscamos destacar as contribuições epistemológicas e metodológicas da Semiótica para a pesquisa em Comunicação, com base principalmente nas contribuições de Santaella e Nöth (2004), Santaella (2000a; 2008) e Romanini (2006; 2016). Debatemos ainda alguns conceitos fundamentais da Semiótica para a compreensão dos processos comunicacionais relacionados às autorrepresentações, tais como categorias fenomenológicas, signo e semiose. Ao longo do texto, discorremos sobre os processos semiósicos com exemplos relacionados ao nosso objeto de estudo.

Ainda no primeiro capítulo, apresentamos a perspectiva semiótica da subjetividade, recorrendo à obra de Peirce a partir dos caminhos traçados por Colapietro (2014). Nesta seção, abordamos o sujeito enquanto signo, mais especificamente como símbolo, e como agente comunicativo (COLAPIETRO, 2014). Outrossim, buscamos diferenciar o eu das autorrepresentações com o apoio das proposições de Wiley (1996) acerca dos conceitos de self semiótico e identidade.

No segundo capítulo, a intenção é desvendar o contexto contemporâneo no qual as autorrepresentações emergem nos ambientes digitais, permeando o debate com alguns conceitos semióticos discutidos no capítulo anterior. Nessa perspectiva, apoiamo-nos principalmente em autores que trazem contribuições para além da Semiótica. A primeira parte do capítulo está dedicada às lógicas do ambiente digital, com a discussão de conceitos como banco de dados (MANOVICH, 2001) e dos impactos dos processos de digitalização nas representações da subjetividade (FLORIDI, 2014). Apresentamos ainda reflexões sobre o funcionamento de algoritmos (GILLESPIE, 2018; ANANNY, 2015) e os processos de "personalização" e "bolha dos filtros" que eles acarretam (PARISER, 2012). Há ainda um pequeno trecho dedicado à discussão do conceito de rede em Musso 
(in PARENTE, 2013), que nos ajuda a evidenciar os movimentos inerentes ao ambiente digital.

Na segunda parte, apresentamos uma reflexão sobre os possíveis impactos que as políticas de uso das redes sociais, os interesses empresariais e o atual sistema econômico e social podem exercer nas autorrepresentações no ambiente digital. Aqui, citamos as políticas de dados e de uso do Instagram (2019a; 2019b), relacionando-as com os aspectos do chamado "capitalismo artista" (LIPOVETZKY; SERROY, 2015). Adicionalmente, apresentamos as reflexões de Sodré (2002) sobre o chamado "bios midiático" e a perspectiva da "sociedade da transparência" de Han (2018), pois acreditamos que elas trazem contribuições importantes para a compreensão do complexo cenário no qual as autorrepresentações se dão, considerando-as como fenômeno comunicacional.

Faz parte deste capítulo, também, uma discussão sobre as trocas comunicacionais a partir do enfoque da cibercultura (LÉVY, 1999) e dos processos participativos em redes sociais digitais (RECUERO, 2012; PISANI; PIOTET, 2010; JENKINS; FORD; GREEN, 2014), uma vez que o self é um agente comunicativo. Após a apresentação das perspectivas teóricas enumeradas acima, discorremos sobre as possibilidades de autorrepresentação no Instagram, explorando os recursos da rede e relacionando-os com a Semiótica.

O terceiro capítulo discorre sobre as opções metodológicas da pesquisa e apresenta a aplicação da abordagem semiótica ao estudo das autorrepresentações relacionadas a perfis profissionais de coaches de carreira no Instagram. Nesta perspectiva, explicamos os procedimentos operados para a coleta de dados, descrevemos o corpus e discutimos os resultados encontrados.

Esclarecemos que optamos por incluir, em notas de rodapé, as versões originais em inglês dos excertos de obras traduzidos por nós para que os leitores tenham acesso direto às mesmas. Adicionamos ainda notas de rodapé para esclarecer algumas expressões e práticas relacionadas ao universo digital.

Por fim, apresentamos no apêndice uma entrevista inédita feita com Vincent Colapietro em abril de 2019, por e-mail, cujo tema foi a obra Peirce e a Abordagem do Self (COLAPIETRO, 2014) e os processos de autorrepresentação em ambientes digitais. 


\section{UM MAPA PARA O ESTUDO DAS AUTORREPRESENTAÇÕES}

O fenômeno da autorrepresentação ganhou destaque com a emergência da chamada cibercultura e a popularização das redes sociais digitais, embora ele seja constitutivo da experiência humana. No ambiente digital, os perfis em redes sociais são um bom exemplo de autorrepresentação na medida em que conjugam fotos, vídeos, textos e outros elementos escolhidos por um determinado sujeito para que funcionem como representação de si mesmo. Por este motivo, eles foram escolhidos como recorte para a discussão dos processos de autorrepresentação nesta pesquisa.

Entretanto, entendemos que a compreensão das autorrepresentações - dentro e fora de ambientes digitais - deve partir de uma investigação da lógica dos processos de criação e circulação de sentidos. Assim, apresentamos neste capítulo as ferramentas teórico-metodológicas da Semiótica Peirceana que podem contribuir para a abordagem de fenômenos comunicacionais contemporâneos relacionados à autorrepresentação.

\subsection{Semiótica e Comunicação}

Entendemos que a autorrepresentação emerge de uma complexa rede de relações que o sujeito mantém com o mundo a seu redor. Assim, a representação da subjetividade por meio de perfis em redes sociais digitais é um processo relacional e comunicacional, que envolve a troca de signos e a construção de narrativas. Nesse sentido, ao observarmos um perfil no Instagram, considerando-o como uma autorrepresentação, podemos nos perguntar: em que contexto esse perfil foi criado? A quais propósitos ele se destina? Quais são os significados criados e compartilhados durante o processo de autorrepresentação? Qual é a influência da rede social e de outros sujeitos na constituição dessa autorrepresentação? Que dinâmicas interferem no ato de se autorrepresentar? De que modo as representações de diferentes subjetividades se relacionam no ambiente digital? Que tipo de consequências essa autorrepresentação pode gerar dentro e fora da rede?

Quando um sujeito cria um perfil em uma rede social, entendemos que ele não está necessariamente buscando retratar a si mesmo em sua totalidade, e, se assim o desejasse, não conseguiria fazê-lo. Mesmo um perfil criado especificamente para destacar qualidades profissionais de uma determinada pessoa não pode representar de modo completo todas as experiências de sua carreira. Em vez disso, poderíamos afirmar que um 
perfil profissional representa certos elementos de um ideal de profissional que se deseja comunicar. Se considerarmos que um perfil digital seja criado de acordo com um determinado propósito, podemos afirmar que ele provavelmente carregará alguns elementos com o potencial de provocar interpretações alinhadas a tal intenção, independentemente do possível intérprete. Ou seja, haveria uma interpretabilidade no perfil circunscrita ao contexto, aos objetivos e aos elementos com os quais ele foi criado. Nessa perspectiva, o perfil funcionaria como um meio capaz de mediar a relação entre o ideal de profissional representado e a potencial interpretação que pode ser feita. Ou seja, por meio do perfil comunicam-se certos atributos relacionados ao objeto da representação.

A partir destas ponderações iniciais, entendemos que o estudo das autorrepresentações no ambiente digital do ponto de vista comunicacional não deve ficar restrito a uma abordagem sobre o emissor, o receptor, o meio, a mensagem ou os efeitos. É necessário investigar as lógicas dos processos de representação para ultrapassar a dicotomia entre sujeito e objeto, emissor e receptor. Nessa perspectiva, a Semiótica desenvolvida pelo filósofo, matemático e lógico norte-americano Charles Sanders Peirce (1839-1914) é o ponto de partida de nossas investigações, na medida em que esta é uma teoria geral sobre as formas como representamos e interpretamos a realidade.

Segundo Santaella (1994, p. 15), a Semiótica é "a ciência que tem por objeto de investigação de todas as linguagens possíveis, ou seja, que tem por objetivo o exame dos modos de constituição de todo e qualquer fenômeno como fenômeno de produção de significação e de sentido”. Essa abordagem lógica permite investigar as inter-relações entre diferentes linguagens, pois o foco não está em uma linguagem ou tecnologia específica, mas no processo de geração de significados.

Embora seja conhecida como uma Teoria dos Signos, a Semiótica Peirceana faz parte de uma arquitetura filosófica mais ampla, que começou a ser construída em meados de 1860 a partir da Fenomenologia e culminou em uma teoria sígnica do conhecimento baseada nos processos mediadores. A ontologia tripartite de Peirce já está presente em seus primeiros artigos publicados entre 1868 e 1871 (ROMANINI, 2016, p. 30), perpassa toda a sua trajetória e é decisiva para a concepção lógica de signo.

Em uma de suas primeiras definições de signo, de 1897, Peirce indica, de modo simplificado, que um signo é aquilo que representa algo, seu Objeto, para alguém, em algum aspecto ou capacidade, criando na mente da pessoa outro signo equivalente ou 
mais desenvolvido, chamado Interpretante (CP 2.228). ${ }^{14}$ Embora esta explicação ainda traga elementos subjetivos, que posteriormente dão lugar a definições mais abstratas, ela já aponta que o signo é um elemento de mediação entre o objeto e o interpretante.

Santaella e Nöth (2004, p. 202, itálico dos autores) alertam para o fato de que, na fase final de sua carreira, Peirce definiu signo como "[...] uma espécie de medium de comunicação entre duas ideias, ou entre um objeto e uma ideia, ou melhor, entre um objeto e uma ideia interpretante que o signo produz ou modifica." Assim, o signo é um meio de comunicação em relação à sua capacidade de mediar, e não em relação à sua dimensão física ou material. Vejamos a definição de Peirce para signo como meio de comunicação, elaborada em 1906:

Um signo é claramente uma espécie de meio de comunicação, e meio de comunicação é uma espécie de meio e um meio é uma espécie de terceiro. [...] Um meio de comunicação é algo, A, que sofrendo a ação de outra coisa, $\mathrm{N}$, por sua vez age sobre algo, I, de maneira que inclui sua determinação por $\mathrm{N}$, de modo que I deve, assim, através de A e apenas através de A, sofrer ação de N. (MS [R] 283). ${ }^{15}$

A noção peirceana de meio de comunicação não diz respeito à tecnologia envolvida nos processos mediadores, mas à complexa função desempenhada por signos que podem assumir diferentes naturezas. A definição de signo como meio indica que o partilhamento de significados só pode correr por mediação, com base na relação triádica indecomponível entre signo, objeto e interpretante. O objeto determina o signo e só pode ser conhecido por meio dele. O signo, por sua vez, determina os efeitos produzidos pelo objeto no processo de significação.

Santaella e Nöth (2004) defendem que, além de ser uma filosofia da ciência e um método geral para a investigação científica, a Semiótica pode ser considerada uma teoria da comunicação. Com base nessa afirmação, os autores pontuam que a ação do signo, denominada por Peirce como semiose, está fundada em um processo comunicacional.

\footnotetext{
${ }^{14}$ Respeitamos aqui o modo de citar a obra de Peirce usado por pesquisadores peirceanos (conhecidos como schollars), baseado nas seguintes convenções: CP identifica os Collected Papers; os números identificam o volume seguido dos parágrafos. O mesmo vale para MS e L, manuscritos editados por R.Robin. A referência completa à obra de Peirce encontra-se nas referências bibliográficas deste trabalho. Além do uso das siglas, usaremos a citação convencional quando nos referirmos à Peirce (2017), edição brasileira que reúne textos traduzidos por José Teixeira Coelho Neto. Para mais informações sobre a obra de Peirce, consultar: <https://peirce.sitehost.iu.edu/robin/rcatalog.htm>. Acesso em: 3 ago. 2020.

15 "A sign is plainly a species of medium of communication, and medium of communication is a species of medium, and a medium is a species of third. [...] A medium of communication is something, A, which being acted upon by something else, $\mathrm{N}$, in its turn acts upon something, $\mathrm{I}$, in a manner involving its determination by $\mathrm{N}$, so that I shall thereby, through A and only through A, be acted upon by N". (MS [R] 283, 1906).
} 
Que a semiótica é também uma teoria da comunicação está implícito, em primeiro lugar, no fato de que não há comunicação sem signos. Em segundo lugar, está implícito no fato de que a semiose é, antes de tudo, um processo de interpretação, pois a ação do signo é a ação de ser interpretado em um outro signo. (SANTAELLA, NÖTH, 2004, p. 160161).

Nessa perspectiva, Romanini (2016, p. 54) argumenta que a Semiótica pode ser compreendida como uma teoria geral da comunicação de natureza transdisciplinar, pois "sendo definida a partir da lógica das relações, sua existência não depende do surgimento de tecnologias ou processos historicamente determinados." Por conseguinte, a Semiótica apresenta-se como uma teoria atemporal, que oferece as bases gerais para o estudo de fenômenos diversos, incluindo os comunicacionais. De acordo com Santaella (2002, p. 6), a Semiótica "[...] funciona como um mapa lógico que traça as linhas dos diferentes aspectos através dos quais uma análise deve ser conduzida, mas não nos traz conhecimento específico da história, teoria e prática de um determinado processo de signos."

Em consonância com os autores citados, a Semiótica foi escolhida como base teórico-metodológica nesta dissertação, na medida em que dispõe de conceitos adequados para a compreensão dos processos de criação e circulação de significados compartilhados socialmente. Outrossim, a Semiótica oferece definições originais sobre a emergência do eu e das representações da subjetividade, pertinentes à discussão contemporânea sobre identidades e autorrepresentações em ambientes digitais. ${ }^{16}$

$\mathrm{O}$ alto nível de generalidade da teoria permite a abordagem de fenômenos comunicacionais sob distintos pontos de vista, bem como sua articulação com aspectos socio-históricos do contexto em que esses processos estão inseridos. Nesse sentido, a investigação empreendida por Charles S. Peirce para desvendar a lógica de funcionamento dos signos oferece à pesquisa em Comunicação fundamentos que possibilitam a discussão da complexidade implícita nas trocas comunicacionais.

Cabe destacar, antes de prosseguirmos, o significado de representação. De acordo com Peirce (2017, p. 61), representar é “estar em lugar de, isto é, estar numa relação com um outro que, para certos propósitos, é considerado por alguma mente como se fosse esse

\footnotetext{
${ }^{16}$ Embora não seja discutido em nossa pesquisa, reconhecemos aqui o importante trabalho de Stuart Hall sobre "identidades culturais". Para mais informações, sugerimos a leitura de A identidade cultural na pósmodernidade (HALL, 2006).
} 
outro." 17 Assim, uma foto ou um conceito, por exemplo, pode representar algo para alguma mente. Da mesma forma, um perfil profissional em uma rede social digital como o Instagram pode cumprir a função de representar algo (como uma determinada ideia) para uma pessoa, de acordo com certos propósitos. Na Semiótica Peirceana, a representação está relacionada ao papel do signo e também à sua relação com o objeto para o intérprete, ou seja, o termo pode ser compreendido como sinônimo de signo ou como relação sígnica. Deste modo, Peirce diferencia os conceitos de representação e signo com o apoio do termo representamen: "quando se deseja distinguir entre aquilo que representa e o ato ou relação de representação, pode-se denominar o primeiro de 'representâmen' e o último de 'representação"” (Ibid., p.61).

\subsection{Da Fenomenologia à definição de Signo}

A Semiótica Peirceana está fundamentada na Fenomenologia. Em meados de 1860, Peirce iniciou seus estudos fenomenológicos com o objetivo de investigar os fenômenos ou o modo de ser da experiência. Ele chamou sua fenomenologia de Faneroscopia, atribuindo-lhe a função de investigar o faneron (fenômeno), ou seja, qualquer coisa que se apresente à mente, independente de sua realidade. (CP 1:284). A intenção do autor era contribuir para a compreensão de como surgem nossas concepções a respeito da realidade e, assim, investigar as origens do conhecimento.

No artigo Sobre Uma Nova Lista de Categorias, publicado em 1867, Peirce realizou uma revisão das categorias de Aristóteles e Kant e propôs pela primeira vez sua ontologia tripartite (ROMANINI, 2006, p. 36). A partir do exame de todos os fenômenos que se apresentam à mente, o filósofo chegou a três categorias formais e universais que estariam presentes em todos eles:

Tento uma análise do que aparece no mundo. Aquilo com que estamos lidando não é metafísica: é lógica, apenas. Portanto, não perguntamos o que realmente existe, apenas o que aparece a cada um de nós em todos os momentos de nossas vidas. Analiso a experiência, que é resultante cognitiva de nossas vidas passadas, e nela encontro três elementos. Denomino-os Categorias. (PEIRCE, 2017, p. 22, itálico do autor).

\footnotetext{
${ }^{17}$ Para Peirce, o conceito de mente não se resume à mente humana, como será discutido nas próximas páginas.
} 
Posteriormente, ele denominou suas categorias como primeiridade, secundidade e terceiridade.

A primeiridade é o universo da originalidade, do acaso, das qualidades, dos sentimentos, da espontaneidade, da possibilidade, da mônada, ou seja, "“[...] aquilo que é sem relação a qualquer outra coisa dentro dele [...]." (PEIRCE, 2017, p. 24, itálico do autor). O autor exemplifica a noção de primeiridade no seguinte trecho:

Sabemos, talvez, porque um meteorito cairia na Terra, se entrasse em seu caminho; mas, qual a razão para os arranjos da natureza estarem feitos de tal modo que este meteorito em particular se achasse no caminho da Terra? Todos estes são fatos que são o que são, simplesmente porque acontecesse que são assim. Na maior parte das vezes, negligenciamos tais fatos; mas há casos, como nas qualidades do sentir, na autoconsciência, etc., nos quais esses lampejos isolados vêm para o primeiro plano. (PEIRCE, 2017, p. 24).

Nesse sentido, a primeiridade é um vir a ser e está relacionada ao fenômeno em seu estágio mais inicial, quando ainda não é possível defini-lo ou relacioná-lo a algo.

A secundidade é o universo da reação, da relação, do aqui e agora, da existência, da força bruta, da causa e efeito, da díada, que "supõe não apenas dois objetos relacionados, mas sim que, além deste estado de coisas, somando-se a este, existe um segundo estado subsequente" (PEIRCE, 2017, p. 23, itálico do autor). Na secundidade, não há racionalização ou interpretação sobre o fenômeno, mas reação de um elemento sobre o outro; é nela que ocorre a "materialização" do fenômeno (ALMEIDA, 2012, p. 11).

Já a terceiridade é o universo da intenção, da continuidade, da inteligência, da regularidade, da lei, do crescimento, do propósito, da representação, da tríada. Ela é mediação ou a "modificação da primeiridade e da secundidade" (PEIRCE, 2000, p. 27). Peirce dá um exemplo que ajuda a esclarecer a questão:

Digo a meu cão que suba e me traga meu livro, o que ele faz. Eis um fato a respeito de três coisas, eu mesmo, o cão e o livro, que não é uma simples soma de fatos relacionados com pares, nem mesmo uma comparação de tais pares. Falo ao cachorro. Menciono o livro. Faço essas coisas juntas. O cão traz o livro. Ele o faz em consequência do que eu fiz. Esta não é toda a história. Eu não apenas falei simultaneamente ao cão e mencionei o livro como também mencionei o livro ao cão; isto é, fiz com que ele pensasse no livro e o trouxesse. Minha relação com o livro foi que pronunciei certos sons que foram compreendidos pelo cão como tendo referência com o livro. O que fiz com o cão, além de exercitar o nervo auditivo, foi, simplesmente, 
induzi-lo a trazer-me o livro. A relação do cão com o livro foi mais manifestadamente dualística; todavia, a significação e a intenção total de seu ato de trazer o livro foi a de obedecer-me. Em toda a ação governada pela razão será encontrada uma triplicidade genuína desse tipo, enquanto que entre pares de partículas ocorrem apenas ações puramente mecânicas. (PEIRCE, 2017, p. 26).

As categorias de Peirce são gerais, dinâmicas e interdependentes, podendo ser identificadas em qualquer tipo de fenômeno, tais como um ruído, uma lembrança, um objeto material, um sentimento, uma palavra, uma conversa ou um filme. (SANTAELLA, 2014). Ou seja, as três categorias fenomenológicas são constitutivas de todo e qualquer fenômeno, embora possa haver a prevalência de uma ou outra categoria.

É na terceiridade que se encontra a noção de signo: "a mediação genuína é o caráter de um Signo" (PEIRCE, 2017, p. 28, itálico do autor). Peirce concebe o signo como uma estrutura triádica, diferentemente da semiologia de Ferdinand de Saussure (1857-1913), baseada na díade significado/significante. Na teoria peirceana, um signo (ou representamen), pode ser definido como

[...] aquilo que, sob certo aspecto ou modo, representa algo para alguém. Dirige-se a alguém, isto é, cria, na mente dessa pessoa, um signo equivalente, ou talvez um signo mais desenvolvido. Ao signo assim criado denomino interpretante do primeiro signo. O signo representa alguma coisa, seu objeto. (PEIRCE, 2017, p. 46).

Apesar da referência às palavras "mente" e "alguém", Santaella (2000a) alerta que elas devem ser tomadas com cautela, uma vez que Peirce as utilizou em algumas ocasiões na tentativa de fazer sua teoria mais compreensível. Entretanto, essas palavras, em vez de apontarem para uma abordagem subjetivista, ajudariam a indicar "[...] a função mediadora do signo entre objeto e interpretante" (SANTAELLA, 2000a, p. 13).

Outra definição apresentada por Peirce destaca o papel mediador dos signos e a importância da lógica das relações na geração de significados:

Um Signo, ou Representâmen, é um Primeiro que se coloca numa relação triádica genuína tal com um Segundo, denominado seu Objeto, que é capaz de determinar um Terceiro, denominado seu Interpretante, que assuma a mesma relação triádica com seu Objeto na qual ele próprio está em relação com o mesmo Objeto. A relação triádica é genuína, isto é, seus três membros estão por ela ligados de um modo tal que não consiste em nenhum complexo de relações diádicas. (PEIRCE, 2017, p. 63, itálico do autor). 
Peirce esclareceu sua abordagem formal e abstrata da estrutura dos processos semióticos ao declarar: "A lógica aqui será definida como semiótica formal. Será dada uma definição de signo que não se refere mais ao pensamento humano do que a definição de uma linha como o lugar que uma partícula ocupa, parte por parte, durante um lapso de tempo "(MS L 75: 363-364). ${ }^{18}$ A definição de signo é lógica, o que fornece à Semiótica um alto nível de generalidade e abstração. Segundo Santaella e Nöth (2004), essas características evidenciam a força da teoria, uma vez que possibilitam a investigação de signos de distintas naturezas, e não apenas de objetos existentes.

Não é a natureza existencial de algo que faz esse algo ser signo, nem ser objeto, nem interpretante, pois qualquer um dos três elementos pode pertencer a qualquer ordem de existência, inclusive a existência de uma ficção ou de uma alucinação. O que os faz funcionar como signo, objeto e interpretante é a relação lógica que se estabelece entre eles, ou seja, o modo como essa tríade se articula. (SANTAELLA; NÖTH, 2004, p. 201).

Podemos esclarecer a lógica triádica entre os elementos do signo com alguns exemplos. Um termômetro, por exemplo, ao marcar a temperatura, pode funcionar como um signo de febre, e a febre, nesse caso, seria o objeto do signo. O termômetro pode indicar febre pois a febre tem uma forma geral, o aumento da temperatura corporal, que pode agir sobre o signo - em outras palavras, o termômetro é capaz de detectar o aumento da temperatura corporal. Assim, podemos afirmar que o objeto determina o signo. $\mathrm{O}$ termômetro, por sua vez, ao marcar a temperatura corporal em um visor, gera um interpretante, que pode ser interpretado por alguém que tenha familiaridade com o termômetro. Nesse sentido, o signo determina o interpretante. Ou seja, a forma do objeto é transmitida do objeto ao interpretante por meio do signo. Assim, por meio do termômetro é possível interpretar que há febre. A febre também poderia funcionar como signo de outro objeto, a SARS-CoV-2, doença causada pelo novo coronavírus. Nesse sentido, a SARS-CoV-2, ao ocupar a posição lógica de objeto, determina a febre, que é o signo, e a febre, ao ocupar a posição lógica de signo, determina o interpretante, que poderia ser interpretado por um médico familiarizado com os sintomas de tal enfermidade

\footnotetext{
18 "Logic will here be defined as formal semiotic. A definition of a sign will be given which no more refers to human thought than does the definition of a line as the place which a particle occupies, part by part, during a lapse of time" (MS L 75. 363-364).
} 
como um de seus indícios. A Sars-CoV-2 também poderia ser objeto de outro signo, como o exame de sangue que identifica a presença do vírus no corpo do paciente.

De acordo com a Semiótica Peirceana, podemos afirmar, de modo ainda simplificado, que qualquer coisa que pode ser representada por um signo assume a posição de objeto, ou seja, não é necessário que o objeto tenha existência material. Por isso, pensamentos, ideias, sonhos, qualidades, elementos ficcionais e virtualidades podem ser objetos. Deste modo, a palavra "fada" funciona como signo capaz de representar um ser imaginário do sexo feminino que teria poderes mágicos. Ao mesmo tempo, qualquer coisa pode assumir a posição lógica de signo e de interpretante. $\mathrm{O}$ aroma de um bolo que está sendo assado em um forno - que a princípio poderia ser classificado como um elemento de primeiridade - pode assumir a posição de signo, indicando que o objeto - o bolo - está pronto para um possível intérprete que esteja acostumado a preparar tal sobremesa ou que tenha certa experiência sobre o aroma característico de um bolo. $\mathrm{O}$ cheiro do bolo poderia gerar como interpretante a ação de apagar o forno; outro interpretante possível seria a salivação gerada pelo desejo de saborear a sobremesa. Isso demonstra a versatilidade da Semiótica e da definição de signo. O que caracteriza um signo é sua função mediadora, embora ele se corporifique em uma forma sensível para cumprir tal função, ainda que seja por meio de um simples aroma.

A origem fenomenológica da Semiótica também possibilita o alargamento das fronteiras da teoria, como pontuam Santaella e Nöth (2004):

Por ter baseado sua semiótica na fenomenologia, ele (Peirce) pode estender a noção de signo tão longe de modo a considerar como signos também os fenômenos que não são inerentemente triádicos, isto é, fenômenos de secundidade e de primeiridade. Desse modo, mesmo uma ação ou reação meramente diádicas podem funcionar como signos tão logo encontrem um intérprete, como, por exemplo, as folhas amarelando nas árvores do hemisfério norte significam que é chegado o outono. (SANTAELLA; NÖTH, 2004, p. 204).

Qualquer coisa tem o potencial de funcionar como signo, bastando, para isso, que encontre um intérprete, ou seja, que seja associado a outra coisa. Nesse sentido, não se pode compreender completamente a noção de signo de forma isolada, mas sempre em relação a outros signos e experiências. Por conseguinte, a análise Semiótica depende da consideração do contexto em que o problema de pesquisa está inserido, ou seja, não basta identificar signos e fazer uma taxonomia usando as nomenclaturas propostas por Peirce, 
uma vez que algo só pode ser considerado signo a partir da perspetiva e dos propósitos da investigação.

\subsection{Semiose como centro do processo comunicacional}

A abordagem do objeto de pesquisa do ponto de vista semiótico requer o desapego ao antigo paradigma funcionalista de Lasswell (1902-1978), que indica que o ato comunicacional deve ser analisado a partir das respostas às perguntas: Quem? Diz o quê? Em que canal? Para quem? Com que efeito? Diferentemente do modelo lasswelliano e seus desdobramentos para a pesquisa em Comunicação, a Semiótica considera a ação do signo como centro do processo comunicacional, como pontua Romanini (2006):

A comunicação, vista pela semiótica, é um processo de partilhamento de significados, de informação, entre a mente emissora e a mente receptora de sorte que, no ato mesmo desse partilhamento, as duas se tornam uma só. É um processo circular e autoalimentado no qual o protagonista não é uma ou outra mente que participa, mas a própria semiose que as conduz no processo de informação. (ROMANINI, 2006, p. 125).

Nessa perspectiva, o conceito de semiose é fundamental para a compreensão da Semiótica, uma vez que ele ajuda a esclarecer que o partilhamento de significados não pode ser compreendido pela investigação fragmentada da mensagem, do meio ou dos efeitos, tampouco pelo estudo de relações diádicas, como aquela entre emissor e receptor. A ação do signo ou semiose diz respeito a cadeias de relações triádicas:

É importante entender o que quero dizer com semiose. Toda ação dinâmica, ou ação de força bruta, física ou psíquica, que ocorre entre dois sujeitos (se eles reagem igualmente um sobre o outro, ou um é agente e o outro paciente, total ou parcialmente) ou de qualquer modo é uma resultante de tais ações entre pares. Mas por "semiose" quero dizer, ao contrário, uma ação, ou influência, que é, ou envolve, uma cooperação de três sujeitos, como um signo, seu objeto e seu interpretante, tal influência tri-relativa não sendo de forma alguma resolvida em ações entre pares. (CP 5:484). ${ }^{19}$

\footnotetext{
19 "It is important to understand what I mean by semiosis. All dynamical action, or action of brute force, physical or psychical, either takes place between two subjects [whether they react equally upon each other, or one is agent and the other patient, entirely or partially] or at any rate is a resultant of such actions between pairs. But by "semiosis" I mean, on the contrary, an action, or influence, which is, or involves, a coöperation of three subjects, such as a sign, its object, and its interpretant, this tri-relative influence not being in any way resolvable into actions between pairs." (CP 5:484).
} 
A semiose está baseada na relação triádica irredutível e indecomponível entre signo, objeto e interpretante e os elementos da tríade só podem ser analisados uns em relação aos outros. Por conseguinte, a ação do signo não pode ser compreendida se a tríade for decomposta em relações mais simples.

Para que o significado de semiose fique mais claro, voltamos à definição de signo. Considerando o signo como um elemento de mediação, podemos afirmar que ele está no lugar do objeto de modo a trazer à tona um interpretante relacionado a esse mesmo objeto, ou seja, o signo coloca em articulação o objeto e o interpretante (ou possível intérprete, se estivermos considerando um fenômeno que envolve pessoas). Como assinalam Santaella e Nöth (2004, p. 202), a comunicação é um aspecto fundamental da semiose, "[...] visto que, em todo processo de comunicação, deve haver uma mediação que permita a passagem, a comunicação, de uma cognição a outra. Essa mediação é exercida pelo signo." Nesse sentido, a Semiótica possibilita que a pesquisa em Comunicação ultrapasse o limite do psicologismo e do sujeito como protagonista do ato comunicacional para assumir a centralidade da semiose, que também pode ser compreendida como comunicação por meio de signos.

Colapietro (2019) esclarece a centralidade da semiose ao destacar que ela está presente em diferentes atividades de signo, incluindo aquelas cuja ação do signo não requer nenhum agente humano, como no exemplo de Peirce do girassol girando ao redor do sol (CP 2.274).

[...] existem casos de atividade de signo em que a ação do signo é unida pela ação de um animal que usa o signo. Por exemplo, o geólogo que está interpretando o significado de um fóssil - (1) a formação de um fóssil é, no sentido de Peirce, uma instância de semiose, sua existência ou significância não depende do ato do intérprete; e (2) o processo de interpretação da significação desse traço geológico, um processo conduzido por um ser consciente. [...] A semiose é primordial, enquanto os agentes que usam signos como os organismos humanos são derivados (eles derivam ou evoluem de processos mais simples). $(\text { COLAPIETRO, 2019) })^{20}$

\footnotetext{
20 "There are however instances of sign-activity in which the agency of the sign is joined by the agency of a sign-using animal (eg, the geologist who is interpreting the significance of a fossil - (1) the formation of a fossil is in Peirce's sense an instance of semiosis, it does not depend for either its being or its significance on the act of the interpreter and (2) the process of interpreting the significance of this geological trace, a process conducted by a conscious [...]. Semiosis is primordial, while sign-using agents such as human organisms are derivative (they derive or evolve out of simpler processes)."

(COLAPIETRO, 2019).
} 
A ação do signo não ocorre de modo isolado. Quando o signo está em ação no mundo, ele está em constante movimento, em uma dinâmica que envolve cadeias de signos e a geração de novos signos. Por isso, é impossível encontrar um signo isolado e estático. Conforme afirma Peirce (2017, p. 29), “em consequência do fato de todo signo determinar um interpretante, que também é um signo, temos signos justapondo-se a signos". Há uma trama ininterrupta de signos que se remetem a outros signos. Esse dinamismo dos signos pode ser compreendido como semiose.

Os três correlatos do signo são de natureza sígnica e o que os diferencia é a posição lógica. Santaella (2000a) chama a atenção para o fato de que o objeto "determina" o signo e este, por sua vez, "determina" o interpretante:

O objeto é algo diverso do signo, diversidade que o signo não pode apagar. Daí haver a determinação do signo pelo objeto e não a mera substituição. O signo não pode substituir o objeto, mas apenas estar no lugar dele e indicá-lo para a ideia que ele produz ou modifica. Isso significa que a ação do signo ou autogeração só se consuma porque ele determina o interpretante (terceiro), que, sendo criado pelo signo, estará mediatamente determinado pelo mesmo objeto que determina o signo. (SANTAELLA, 2000a, p. 25, itálico da autora).

Ou seja, o signo está, desde o princípio, limitado pelo próprio objeto, enquanto este só pode ser conhecido a partir do signo. Assim, a semiose é " [...] o processo pelo qual o objeto se revela [...] através da mediação dos signos” (SANTAELLA, 2008, p. 100). Grosso modo, pode-se afirmar que o objeto ocupa o lugar lógico de emissor da informação, embora ele não deva ser confundido com o sujeito existencial ou psicológico. O objeto é um complexo contextual que pode ser constituído também pelo sujeito, conforme será esclarecido mais adiante.

Além da operação de determinação que o objeto exerce sobre o signo e este sobre o interpretante, Santaella e Nöth (2004) destacam que a posição mediadora do signo também atua no sentido contrário, no chamado "vetor da representação", em uma referência à proposta de Parmentier (1985 apud SANTAELLA; NÖTH, 2004, p. 201). Nessa perspectiva, a semiose opera nos sentidos de determinação e de representação:

O signo faz face simultaneamente em duas direções: ele faz face para $o$ objeto em uma posição passiva de ser determinado, ao mesmo tempo em que está na posição ativa de representar o objeto para o interpretante, fazendo, então, face para o interpretante em uma posição ativa de determinação. (SANTAELLA; NÖTH, 2004, p. 201). 
Para a análise dos processos semióticos, se pensarmos em um fenômeno que envolve sujeitos, como a criação de perfis no Instagram, isso implica que, no sentido da representação, os significados gerados pelo signo - o perfil, em nosso exemplo dependem também das experiências do intérprete, ou seja, os interpretantes gerados pelo signo podem variar de acordo com as particularidades envolvidas no processo semiótico, embora o signo carregue em si alguns elementos relacionados ao objeto, na medida em que é determinado por ele.

Romanini (2016) lembra que a Semiótica Peirceana considera que o universo é composto por signos e só é possível ter acesso à realidade por meio deles. Entretanto,

O signo não cria a significação, mas é a significação que se corporifica em signos particulares, que cumprem a função de meios de transmissão da informação, aumentando a razoabilidade, não nesta ou naquela mente particular, ou em qualquer número finito de mentes particulares, mas na mentalidade que permeia e une todos os que participam do processo de comunicação. (ROMANINI, 2016, p. 28).

Ou seja, os signos, ao transmitirem significados e se relacionarem a outros signos em um processo contínuo, contribuem para ampliar o entendimento do que seria a realidade.

Para Peirce (2017, p.28-29), a ação dos signos é um processo contínuo, dinâmico e sem final definido, em que um signo representa um objeto para um interpretante (que pode ser apenas potencial), produzindo novos signos mais desenvolvidos. Entretanto, o signo não representa o objeto em sua totalidade, mas “[...] pressupõe uma familiaridade com algo a fim de veicular alguma informação ulterior sobre esse algo" (PEIRCE, 2017, p. 47). Ou seja, o objeto é algo diverso do signo e este, por sua vez, possui características próprias, independentemente do objeto. O signo seleciona algumas qualidades do objeto que permitirão que ele determine interpretantes relacionados a esse mesmo objeto.

Além dos três correlatos que compõem o signo - signo (ou representamen), objeto e interpretante -, Peirce faz distinções entre dois aspectos do objeto e três do interpretante (CP 8.343). Assim, há seis aspectos fundamentais envolvidos no processo de semiose: o signo, o objeto dinâmico, o objeto imediato, o interpretante imediato, o interpretante dinâmico e o interpretante final.

De acordo com Peirce (2017, p. 168), o objeto imediato é a parte do objeto que é efetivamente representada no signo e, por esse motivo, faz parte do signo; já o objeto dinâmico é o objeto ao qual o signo se refere ou indica, seja ele real ou ficcional. Como 
observa Santaella (2000a, p. 40), “[...] o signo só pode, de algum modo, estar no lugar do objeto porque há, no próprio signo, algo que, de certa maneira, estabelece sua correspondência com o objeto. Este algo - que liga o signo ao objeto dinâmico - é o objeto imediato [...]."

O interpretante imediato é uma das possibilidades de interpretação do signo e está contida nele, ou seja, é interno ao signo: "o signo tem uma objetividade própria e seu interpretante interno depende daquilo que o signo objetivamente tem potencial para significar" (SANTAELLA, 2008, p. 102). Assim, o interpretante imediato tem uma potência que precisa ser efetivada pelo interpretante dinâmico, e que está relacionada a hábitos socialmente constituídos, como detalharemos a seguir.

O interpretante dinâmico, por sua vez, é o efeito produzido pelo signo e está relacionado à efetivação de algumas potencialidades do signo. Segundo Santaella (2008, p. 102), o interpretante dinâmico "[...] é a posição lógica ocupada pelos intérpretes existentes, singulares, psicológicos, espaço-temporalmente situados”. Assim, o signo pode ter vários interpretantes dinâmicos, em que cada intérprete particular pode fazer interpretações distintas, de acordo com seu repertório, dentro das potencialidades de interpretação contidas no signo.

Já o interpretante final é o resultado interpretativo ao qual todo intérprete estaria destinado a chegar, ou seja, ele "revela no que o signo se transformaria, ao final do processo, se todas as suas potencialidades fossem desenvolvidas" (ROMANINI, 2016, p. 51). O interpretante final seria um limite ideal, que não pode ser atingido completamente. Posteriormente, ao fazer uma aproximação entre a Semiótica e seu Pragmatismo ${ }^{21}$, Peirce refinou a noção de interpretante final, descrevendo-o como o signo capaz de produzir um efeito potencial ou real de mudar hábitos de conduta (BERGMAN, 2010, p. 144). Desse modo, a partir da perspectiva da Comunicação, o interpretante final seria o propósito para o qual estão orientadas as trocas comunicacionais (ROMANINI, 2016).

A partir das discussões acima, voltamos aos seis aspectos fundamentais do signo: signo, objeto imediato, objeto dinâmico, interpretante imediato, interpretante dinâmico e

\footnotetext{
${ }^{21}$ O Pragmatismo de Peirce pode ser definido como um método para a realização de investigações e para a busca da Verdade. As bases de seu Pragmatismo foram desenvolvidas nos artigos The Fixation of Belief (PEIRCE, 1877) e How to Make Our Ideas Clear (PEIRCE, 1878), embora a palavra pragmatismo não esteja presente em nenhum deles. Após 1900, o autor reformulou o Pragmatismo, denominando-o Pragmaticismo, a partir da aproximação entre a Semiótica e a Metafísica. Nesta dissertação, optamos por não aprofundar a discussão sobre a máxima pragmática peirceana (CP 5:402) e seus desdobramentos. Entretanto, recorremos ao artigo O que é Pragmatismo, publicado originalmente na revista The Monist em 1905, para discorrer sobre o self semiótico. Para um aprofundamento sobre o Pragmatismo Peirceano, recomendamos a leitura da obra Sobre Pragmatismo (WALL, 2007).
} 
interpretante final. O exemplo de uma situação cotidiana dado por Peirce em um fragmento datado de 1909, quando o autor já estava na fase final de sua carreira, ajudanos a compreender o funcionamento desses aspectos dentro da pesquisa em Comunicação:

\begin{abstract}
Por exemplo, suponhamos que eu acorde de manhã antes de minha mulher e que, a seguir, ela desperte e pergunte "Como está o dia, hoje?". Isto é um signo cujo Objeto, tal como está expresso, é o tempo naquele momento, mas cujo Objeto Dinâmico é a impressão que eu presumivelmente extrai do ato de espiar por entre as cortinas da janela. E cujo Interpretante, tal como expresso, é a qualidade do tempo, mas cujo Interpretante Dinâmico é a minha resposta à pergunta dela. Mas, além desse, existe um terceiro Interpretante. O Interpretante Imediato é aquilo que a Pergunta expressa, tudo aquilo que ela imediatamente expressa, e que eu enunciei imperfeitamente, acima. O Interpretante Dinâmico é o efeito real que ela tem sobre mim, seu intérprete. Mas a Significação dela, ou o Interpretante Último, ou Final é o objetivo de minha mulher ao fazer a pergunta, qual o efeito que a resposta à pergunta terá sobre seus planos para aquele dia. (PEIRCE, 2017, p. 168).
\end{abstract}

Se tomarmos como exemplo nosso objeto de estudo, qual seja, as autorrepresentações de coaches de carreira feitas em perfis no Instagram, podemos identificar os seguintes aspectos da semiose, do ponto de vista da interface da rede (onde ocorrem as interações entre os usuários): 1) o perfil, construído a partir de elementos escolhidos pelo sujeito que se autorrepresenta e as interações relacionadas a ele, entre outros aspectos que serão discutidos no próximo capítulo, ocuparia o lugar lógico do Signo; 2) o profissional representado, ou o ideal de profissional que se deseja comunicar a partir da representação no perfil, considerando toda a sua complexidade, seria o Objeto Dinâmico; 3) o Objeto Imediato seriam as fotos, os vídeos e os elementos que efetivamente estão no perfil e se relacionam com o objeto dinâmico, ou seja, seria o modo como o objeto é representado; 4) o Interpretante Imediato é o potencial efeito ou consequência que o signo pode produzir caso venha a ser efetivamente interpretado, considerando os hábitos constituídos socialmente. Assim, se um perfil traz uma foto de uma pessoa com um diploma nas mãos, os interpretantes imediatos são os potenciais efeitos que essa imagem pode gerar, podendo ser atualizados em interpretantes dinâmicos como: pessoa que concluiu uma graduação, pessoa que tem conhecimento atestado por uma instituição de ensino sobre um certo tema, dependendo de quem interpreta dinamicamente; 5) as interpretações feitas por intérpretes que se relacionam com o perfil 
são exemplos de Interpretante Dinâmico e poderiam ser identificadas por meio de curtidas e comentários em uma foto, envio de mensagens diretas ao coach, compartilhamento da foto, entre outras possibilidades, como um pensamento relacionado ao profissional representado; 6) já o Interpretante Final estaria relacionado à efetivação dos propósitos que o coach tem ao se autorrepresentar, que poderiam ser a venda de serviços de coach de carreira, o convite para entrevistas em programas de televisão, a ampliação da base de seguidores do perfil, etc. Destacamos, entretanto, que no ambiente digital, a semiose não envolve apenas esses elementos, uma vez que toda informação é digitalizada e, além das interações entre usuários, há ainda as programações de algoritmos, as restrições e possibilidades oferecidas pela interface, e as reconfigurações que surgem a partir do entrelaçamento entre as ações dos sujeitos e os aspectos técnicos e não-humanos desses espaços.

É importante assinalar que o estudo dos interpretantes possibilita a compreensão dos significados que um signo é capaz de gerar. Além da tricotomia que divide o interpretante em imediato, dinâmico e final, Peirce apresentou uma segunda tricotomia do interpretante, com base nas três categorias fenomenológicas, denominando-os emocional, energético e lógico. Conforme esclarece Santaella (2000a, p. 78), o interpretante emocional é o primeiro efeito do signo, sendo o "aspecto qualitativo do efeito produzido pelo signo". O interpretante energético, como o nome indica, está relacionado à liberação de uma energia e "pode ser uma mera reação muscular em relação ao mundo exterior ou corresponder à manipulação e exploração das imagens do nosso mundo interior" (SANTAELLA, 2000a, p. 79). Por fim, o interpretante lógico é o entendimento gerado pelo signo, ou seja, o pensamento ou uma regra geral.

Santaella (2000a) e Romanini (2006, p. 119) pontuam que há divergências entre os estudiosos da obra de Peirce, conhecidos como schollars, sobre essa segunda tricotomia dos interpretantes, pois, para alguns, ela deveria ser aplicada apenas ao interpretante dinâmico; para outros ela deveria ser considerada para os interpretantes imediato, dinâmico e final; e há ainda quem defenda que a divisão emocional, energético e lógico seria apenas uma nova terminologia. Sem nos delongarmos nessa discussão, consideramos, em consonância com os autores supracitados, que cada um dos interpretantes deve ter a subdivisão triádica em emocional, energético e lógico. Pontuamos que não entraremos nesse nível de detalhamento em nossa análise, embora essa tricotomia forneça subsídios para a compreensão dos processos semióticos relacionados à autorrepresentação. 
A semiose também está relacionada ao contexto em que se insere. Nesse sentido, há duas condições para que haja interpretação do signo: o domínio do sistema de signos e um certo conhecimento sobre o objeto que o signo professa representar, ou seja, alguma "experiência colateral":

[...] experiência colateral é algo que está fora do signo, portanto fora do interpretante que o próprio signo determina. Na medida em que o interpretante é uma criatura gerada pelo próprio signo, essa criatura recebe do signo apenas $\mathrm{o}$ aspecto que ele carrega na sua correspondência com o objeto e não todos os outros aspectos do objeto que o signo não pode recobrir. (SANTAELLA, 2000a, p. 36).

Conforme assinala Bergman (2010, p. 152-153), "a experiência em questão não precisa ser diretamente do objeto em questão; é suficiente que o intérprete possa fazer alguma conexão entre o objeto referido e a própria experiência colateral". ${ }^{22}$ Para uma melhor compreensão, vejamos como Peirce (2017) esclarece o tema:

[...] por observação colateral entendo uma prévia familiaridade com aquilo que o signo denota. Assim, se o Signo for a sentença 'Hamlet era louco', para compreender o que isto significa deve-se saber que, às vezes, os homens ficam nesse estado estranho; deve-se ter visto homens loucos ou deve-se ter lido sobre eles; e será melhor se se souber especificamente (e não houver necessidade de ser impelido a presumir) qual era a noção que Shakespeare tinha da insanidade. Tudo isso é observação colateral e não faz parte do Interpretante. (PEIRCE, 2017, p. 161-162, itálico do autor).

Assim, a experiência colateral funciona como ponto de partida para o processo de interpretação, pois ela produz uma espécie de familiaridade entre o objeto e a experiência de possíveis intérpretes. Embora o signo carregue certos elementos que permitem sua interpretação, a semiose só pode ocorrer se os eventuais intérpretes compartilharem ao menos uma noção comum do objeto dinâmico que o signo representa.

A noção de semiose e dos seis aspectos fundamentais do signo indica que o estudo dos processos de comunicação pode se desvencilhar das amarras do sujeito, uma vez que, embora intérpretes humanos devam ser considerados no recorte do fenômeno investigado, a geração e o compartilhamento de significados dependem de processos coletivos e que,

\footnotetext{
22 "the experience in question need not be directly of the object in question; it is sufficient that the interpreter can make a connection between the object referred to and his or her collateral experience." (BERGMAN, 2010, p. 152-153)
} 
em alguns casos, ultrapassam a semiose antropocêntrica. Outrossim, o signo em si mesmo possui potencialidades que, no decorrer da semiose, podem ou não ser interpretadas.

\subsection{Os signos e seus aspectos icônicos, indiciais e simbólicos}

A Teoria Semiótica está baseada em tríades. A partir das três categorias fenomenológicas, Peirce demonstrou que os signos são divisíveis em três tricotomias. De acordo com o primeiro aspecto, ou seja, o signo em relação a ele mesmo, os signos podem ser definidos como: qualissigno, quando o signo é uma qualidade de sentimento, uma mera possibilidade; sinsigno, quando algo existente e real é um signo; e legissigno, quando o signo é uma lei, uma convenção social (PEIRCE, 2017, p. 52).

A tríade mais conhecida delas é a que define o signo em conexão com o objeto, classificando-o como: ícone, quando o signo representa o objeto por uma relação de semelhança ou qualidade; índice, quando o signo possui uma conexão com seu objeto ou é afetado por ele; e símbolo, quando o signo é uma lei, um conceito, sem nenhuma conexão com o objeto (PEIRCE, 2017, p.52). Entendemos que as definições de ícone, índice e símbolo são fundamentais para esta pesquisa, uma vez que elas nos permitem identificar o modo como os perfis no Instagram - considerados aqui como signos - são determinados pelo objeto dinâmico, ou seja, a partir de quais mecanismos as representações das subjetividades ocorrem, considerando-se o recorte de perfis profissionais de coaches de carreira.

Santaella (2000a, p. 109) destaca que a identificação de um signo como ícone, índice ou símbolo não é estática, mas pode variar de acordo com a função que ele desempenha na semiose: "a tríade ícone, índice e símbolo diz respeito primariamente à distinção entre três espécies de identidades semióticas que um signo pode ter em razão de três espécies de relações em que o signo pode estar para com o objeto, como signo desse objeto.” Assim, apresentamos uma definição complementar de ícone, índice e símbolo, que exemplifica as relações que o signo mantém com o objeto e com o interpretante:

O Ícone não tem conexão dinâmica alguma com o objeto que representa; simplesmente acontece que suas qualidades se assemelham às do objeto e excitam sensações análogas na mente para a qual é uma semelhança. Mas, na verdade, não mantém conexão com elas. O Índice está fisicamente conectado com seu objeto; formam, ambos, um par orgânico, porém a mente interpretante nada tem a ver com essa conexão, exceto o fato de registrá-la, depois de ser estabelecida. O símbolo está conectado a seu objeto por força da ideia da mente que usa 
o símbolo, sem a qual essa conexão não existiria. (PEIRCE, 2017, p. 73).

De acordo com Peirce (2017), os aspectos icônicos, indiciais e simbólicos dos signos têm papel fundamental na cognição:

[...] descobriu-se que há três tipos de signos indispensáveis ao raciocínio; o primeiro é o signo diagramático ou ícone, que ostenta uma semelhança ou analogia com o sujeito do discurso; o segundo é o índice que, tal como um pronome demonstrativo ou relativo, atraia a atenção para o objeto particular que estamos visando sem descrevê-lo; o terceiro (ou símbolo) é o nome geral ou descrição que significa seu objeto por meio de uma associação de ideias ou conexão habitual entre o nome e o caráter significado. (PEIRCE, 2017, p. 10, itálico do autor).

Pontuamos que o excerto acima pertence a um artigo publicado originalmente por volta de 1885. Nesse sentido, a referência a "sujeito do discurso" não deve ser tomada como indício de personalização da Semiótica, mas como parte do esforço do autor em busca do esclarecimento e do desenvolvimento de sua teoria. Cabe assinalar que Peirce reescreveu e aprimorou seus principais conceitos ao longo de sua vida, tornando-os cada vez mais lógicos e abstratos.

Em relação ao interpretante, os signos podem receber as seguintes denominações: rema, quando é uma possibilidade qualitativa; dicente, quando é um signo de existência real; e argumento, quando é um signo de lei (PEIRCE, 2017, p. 53). A partir da combinação lógica dessas três tricotomias, Peirce (2017, p. 55-58) chegou a dez classes de signos genuínos, que não discutiremos na presente dissertação, pois nosso objetivo não é fazer a taxonomia dos signos de nosso objeto de pesquisa. Entretanto, cabe pontuar que os signos genuínos são aqueles que estão na categoria da terceiridade, sendo formados por uma relação triádica indecomponível entre signo, objeto e interpretante, embora englobem elementos de primeiridade (qualidade) e de secundidade (relação). Nesse sentido, os signos genuínos só podem desempenhar seu papel se tiverem um interpretante capaz de identificá-los:

Um Signo Genuíno é um Signo Transuasional, ou Símbolo, que é um signo cuja virtude significante se deve a um caráter que só pode ser compreendido com a ajuda de seu Interpretante. Toda emissão de um discurso é exemplo disso. Se os sons foram, originalmente, em parte icônicos, em parte indiciais, esses caracteres há muito tempo perderam sua importância. As palavras apenas representam os objetos que representam, e significam as qualidades que significam, porque vão 
determinar, na mente do ouvinte, signos correspondentes. (PEIRCE, 2017, p. 28).

Para compreender os signos genuínos, voltamos às definições de ícone, índice e símbolo. A foto de uma flor pode ser interpretada com um ícone que seleciona as qualidades do objeto; o cheiro exalado pela flor pode ser interpretado como um índice de sua presença no ambiente; a palavra "flor" pode ser interpretada como um símbolo representando uma classe de objetos por meio da convenção da língua portuguesa. No entanto, para que a palavra “flor" gere interpretantes, é necessário que os falantes tenham conhecimento prévio do que seja uma flor (uma compreensão sobre os predicados envolvidos na definição dessa palavra), e sejam capazes de reconhecer os objetos denotáveis pela palavra "flor" (a extensão do conjunto desses objetos). Ou seja, os símbolos têm uma parte icônica (predicados que incorporam as informações apreendidas) e uma parte indicial (tudo que eles denotam, expressando informações). Assim, é necessário uma familiaridade, uma experiência prévia ou uma "experiência colateral" com os objetos que o símbolo professa representar.

Um Símbolo é uma lei ou regularidade do futuro indefinido. Seu Interpretante deve obedecer à mesma descrição, e o mesmo deve acontecer com o Objeto imediato completo, ou significado. Contudo, uma lei necessariamente governa, ou 'está corporificada em' individuais, e prescreve algumas de suas qualidades. Consequentemente, um constituinte de um Símbolo pode ser um índice, e um outro constituinte pode ser um ícone. Um homem que caminha com uma criança, levanta o braço para o ar, aponta e diz: 'Lá está um balão'. O braço que aponta é uma parte essencial do símbolo, sem a qual este não veicularia informação alguma. Mas, se a criança perguntar: 'O que é um balão?', e o homem responder: 'É algo como uma grande bolha de sabão', ele torna a imagem uma parte do símbolo. (PEIRCE, 2017, p. 71).

De acordo com as definições da Semiótica Peirceana, os símbolos são os únicos tipos de signo capazes de compartilhar informação, pois eles sintetizam ícones onde a informação seja conotada com índices onde a informação é denotada; dentro dos símbolos, os ícones são responsáveis pela compreensão da realidade, enquanto os índices estão relacionados à extensão, conforme discute Nöth (2013). Entretanto, para funcionar plenamente na semiose, o símbolo precisa ser materializado numa réplica, ou token, que é sua instanciação em um determinado contexto (CP 4:537). Assim, a palavra "balão" na língua portuguesa é um símbolo que pode assumir significados diferentes, dependendo 
de sua instanciação: ela pode referir-se a um objeto feito de papel e inflado com ar aquecido, ou a um objeto esférico constituído de borracha, ou a um recipiente esférico usado em experimentos químicos, ou até mesmo ao local em que veículos fazem o retorno.

\subsection{A arquitetura filosófica peirceana e suas implicações para a Semiótica}

Antes de prosseguirmos a discussão sobre as autorrepresentações em perfis no Instagram, é importante apresentar outros conceitos peirceanos fundamentais para o estudo de nosso objeto, na medida em que estão interligados e fornecem subsídios para a compreensão da Semiótica. Para isso, pontuamos que Peirce propôs, por volta de 1902, uma classificação das ciências (CP 1:176-1:283). Segundo Romanini (2006),

Peirce queria produzir um esquema classificatório a partir das regularidades presentes na natureza, relacionando ramo científico a um desses padrões naturais. Dessa forma, seria possível criar uma classificação das ciências ampla e bem fundamentada, capaz de englobar não apenas as ciências passadas e presentes, mas também deixar ramos abertos para serem preenchidos por ciências que ainda deverão ser descobertas no futuro. (ROMANINI, 2006, p. 73).

Assim, o autor partiu das três categorias fenomenológicas e da observação da experiência para encontrar regularidades capazes de ordenar as ciências, levando em consideração seus distintos níveis de generalidade e abstração. Como explica Romanini (2016, p. 17), a proposta desse método seria gerar uma classificação em que as ciências mais abstratas forneceriam subsídios para as menos abstratas. Peirce dividiu inicialmente as ciências em: a) Ciências da Descoberta, que são teóricas e estão dedicadas à pesquisa em si, discutindo questões mais abstratas e gerais; b) Ciências da Revisão, que são responsáveis pela organização e pela divulgação dos resultados da primeira; e c) Ciências Práticas, que são voltadas a questões aplicadas.

O esquema a seguir demonstra a organização das Ciências da Descoberta proposta por Peirce:

\section{Matemática}

2. Filosofia 
2.1 Fenomenologia

\subsection{Ciências Normativas}

\subsubsection{Estética}

\subsection{2 Ética}

\subsubsection{Lógica ou Semiótica}

\subsubsection{Gramática Especulativa}

\subsubsection{Lógica Crítica}

\subsubsection{Metodêutica ou Retórica Especulativa}

\subsection{Metafísica}

\section{Ciências Especiais ou Idioscopia}

Essa disposição das ciências não indica subordinação de uma por outra, mas demonstra que a mais geral fornece subsídios para as menos gerais. Assim, a Filosofia busca seus princípios fundamentais na Matemática. A organização acima aponta para a importância da base fenomenológica na arquitetura filosófica peirceana. Ou seja, a Fenomenologia, enquanto primeiro nível da Filosofia, fornece subsídios para as Ciências Normativas e para a Metafísica.

A Semiótica, entendida como sinônimo de Lógica, é classificada como Ciência Normativa, uma ciência formal que deriva da Fenomenologia dentro da organização proposta por Peirce. Enquanto a Fenomenologia estuda o modo como as coisas são experimentadas, as Ciências Normativas têm como objetivo estudar as condições do que deve ser. Como esclarece Peirce:

As Ciências Normativas, a Estética, a Ética e a Lógica, [...] estão circunscritas respectivamente a averiguar como o Sentimento, a Conduta e o Pensamento devem ser controlados, supondo que estejam sujeitos em certa medida, e apenas em parte, ao autocontrole, exercidos por meio da autocrítica e da formação proposital de hábitos, pois o senso comum nos diz que são em certa medida controláveis. (MS 655: $24) .{ }^{23}$

\footnotetext{
23 "The Normative Sciences, Esthetics, Ethics, and Logic, [...] are confined respectively to ascertaining how Feeling, Conduct, and Thought ought to be controlled supposing them to be subject in a measure, and only in a measure, to self-control, exercised by means of self-criticism, and the purposive formation of habit, as common sense tells us they are in a measure controllable." (MS 655:24).
} 
Segundo Peirce, a divisão das Ciências Normativas também é regida pelas categorias fenomenológicas (CP 5:129). Santaella (2000b, p. 97) esclarece que com o termo "ciências normativas" o autor "[...] quis se referir ao estudo daquilo que deve ser, num futuro condicional, o que exclui do seu campo tanto a compulsão incontrolada quanto o determinismo rígido."

Entre as ciências normativas, a Estética, a mais geral delas, está dedicada ao estudo do que é admirável em si, correspondendo à primeiridade, e a Ética, por sua vez, corresponde à secundidade, é fundamentada pela Estética e está dedicada ao estudo da ação ou da conduta propositada (SANTAELLA, 2000b, p. 97-98). Por fim, a Lógica ou Semiótica corresponde à terceiridade, está assentada a partir de fundamentos estéticos e éticos, e está voltada ao estudo dos signos e das formas de pensamento (ROMANINI, 2006, p. 75).

A Semiótica também se divide em três ramos de estudo:

A lógica é a ciência das leis necessárias gerais dos Signos e, especialmente, dos Símbolos. Como tal, tem três departamentos. Lógica obsistente, lógica em sentido estrito, ou Lógica Crítica, é a teoria das condições gerais da referência dos Símbolos e outros Signos aos seus Objetos manifestos, ou seja, é a teoria das condições da verdade. Lógica Originaliana, ou Gramática Especulativa, é a doutrina das condições gerais dos símbolos e outros signos que têm o caráter significante. É deste departamento da lógica geral que nós estamos agora ocupando. Lógica Transuasional, que denomino de Retórica Especulativa, é, substancialmente, aquilo que é conhecido pelo nome de metodologia, ou, melhor, metodêutica. É a doutrina das condições gerais da referência dos Símbolos e outros Signos aos Interpretantes que pretendem determinar. (PEIRCE, 2017, p. 29, itálico do autor.)

Assim como nas ciências normativas a Estética e a Ética fornecem subsídios para a Semiótica, a Semiótica também tem uma relação de implicação em que a Gramática Especulativa determina a Lógica Crítica e a Metodêutica. A Gramática Especulativa, como o próprio nome diz, funciona como uma gramática dos signos, ou seja, descreve e analisa as condições e os tipos de signos. Com base nos tipos de signos possíveis, a Lógica Crítica estuda as condições de verdade e os tipos de argumento ou raciocínio, quais sejam, abdutivo, dedutivo e indutivo. Cabe destacar que apenas símbolos - signos genuínos, pertencentes à categoria da terceiridade - podem ser argumentos, além de também poder ser classificados como termos ou proposições, conceitos que não serão discutidos aqui (PEIRCE, 2017, p. 29). 
Por fim, a Metodêutica está dedicada a investigar os métodos por meio dos quais o raciocínio busca a Verdade (PEIRCE, 2017, p. 35-36). Como destaca Romanini (2006),

O estudo das propriedades formais dos signos é o papel do primeiro ramo da semiótica, que Peirce chamou de gramática especulativa. $\mathrm{O}$ segundo ramo é o da lógica Crítica, ou o estudo das condições que permitem ao signo representar verdadeiramente. O terceiro ramo, finalmente, é o da comunicação, que Peirce também chama de retórica especulativa ou metodêutica - o estudo da transferência de informação e dos métodos de pesquisa que nos servem na busca pela Verdade. (ROMANINI, 2006, p. 4).

A hierarquia das ciências proposta por Peirce indica ainda que a Metafísica é fundamentada pela Fenomenologia e pelas Ciências Normativas, ou seja, pelos dois níveis anteriores que compõem sua Filosofia. A Metafísica é a área da Filosofia que estuda "a natureza do mundo objetivo", como pontua Santaella (2002, p. 98). É nela que encontramos alguns subsídios para a compreensão da subjetividade a partir da Semiótica, que serão discutidos mais adiante. Aqui, vamos nos deter a alguns conceitos da Metafísica Peirceana, sem detalhar as suas divisões.

De forma resumida, Peirce defendeu a hipótese metafísica de que o surgimento do universo tenha ocorrido por puro acaso. À existência do acaso absoluto e da aleatoriedade Peirce deu o nome de Tiquismo (do grego tyché, acaso), que daria origem a uma cosmologia evolutiva (CP 6:102). Segundo essa cosmologia, a própria evolução levaria às regularidades presentes na natureza. Com o Tiquismo, Santaella (2002, p. 99) esclarece que Peirce não negou a existência de leis na natureza; na realidade, ele advogou contra o determinismo ao reconhecer elementos de incerteza e espontaneidade no universo, que seriam os responsáveis pela diversidade e pelo crescimento do mesmo (CP 6:201; CP 6:59).

Ao lado do Tiquismo, Peirce desenvolveu a doutrina do Sinequismo, considerada por ele como central em sua Metafísica. O Sinequismo é definido como "a tendência de considerar a continuidade como uma ideia de importância primordial na filosofia" (CP 6:103). ${ }^{24} \mathrm{O}$ conceito foi apresentado no artigo A Lei da Mente (The Law of Mind, no inglês), publicado em 1892. O Sinequismo está relacionado à defesa da relação entre todas as coisas do universo por meio de um contínuo. Em outras palavras, Peirce propõe uma

\footnotetext{
24 "The tendency to regard continuity, in the sense in which I shall define it, as na idea of prime importance in philosophy may conveniently be termed synechism" (CP 6:103).
} 
doutrina em que a continuidade está presente em todos os domínios da experiência. Para o autor, sua Metafísica como um todo pode ser denominada Sinequismo:

Embora o tiquismo entre nela, entra apenas como subsidiário do que realmente é a característica da minha doutrina, a saber, minha insistência na continuidade, ou Terceiridade, e, para garantir à Terceiridade a sua função realmente dominante, eu [acho indispensável] que ela seja uma terceira e que a Primeiridade, ou o acaso, e a Secundidade, ou reação bruta, são outros elementos, sem a independência das quais a Terceiridade não teria nada sobre o que operar. Assim, gosto de chamar minha teoria de Sinequismo, porque repousa no estudo da continuidade. (CP 6:202). ${ }^{25}$

Peirce (1892) parte da análise de como as ideias se espalham por meio de associações e generalizações para propor uma lei que pudesse explicar a evolução do universo. Segundo o filósofo, o universo é regido por uma lei geral, chamada por ele de "lei da mente":

A análise lógica aplicada aos fenômenos mentais mostra que existe apenas uma lei da mente, a saber, que as ideias tendem a se espalhar continuamente e a afetar certas outras que estão para elas em uma relação peculiar de afetação. Nessa difusão, eles perdem intensidade e, principalmente, o poder de afetar os outros, mas ganham generalidade e se fundem com outras ideias. (PEIRCE, 1892, p. 534; CP 6:104). ${ }^{26}$

De acordo com Peirce (1892), a tendência da mente a fazer generalizações pode ser descrita como hábito:

[...] o sentimento que ainda não emergiu na consciência imediata já é afetável e já afetado. Na verdade, isso é hábito, em virtude do qual uma ideia é trazida à consciência presente por um vínculo que já havia sido estabelecido entre ela e outra ideia ainda no futuro. (PEIRCE, 1892, p. 551 ; CP 6:141). ${ }^{27}$

\footnotetext{
25 "For although tychism does enter into it, it only enters as subsidiary to that which is really, as I regard it, the characteristic of my doctrine, namely, that I chiefly insist upon continuity, or Thirdness, and, in order to secure to thirdness its really commanding function, I find it indispensable fully [to] recognize that it is a third, and that Firstness, or chance, and Secondness, or Brute reaction, are other elements, without the independence of which Thirdness would not have anything upon which to operate. Accordingly, I like to call my theory Synechism, because it rests on the study of continuity." (CP 6:202).

26 "Logical analysis applied to mental phenomena shows that there is but one law of mind, namely, that ideas tend to spread continuously and to affect certain others which stand to them in a peculiar relation of affectibility. In this spreading they lose intensity, and especially the power of affecting others, but gain generality and become welded with other ideas. (PEIRCE, 1892, p. 534; CP 6.104)."

27 " [...] feeling which has not yet emerged into immediate consciousness is already affectible and already affected. In fact, this is habit, by virtue of which an idea is brought up into present consciousness by a bond that had already been established between it, and another idea while it was still in futuro". (PEIRCE, 1892 , p. 551; CP 6.141)
} 
Para o autor, o hábito é formado quando uma ideia geral é capaz de gerar certas reações (CP 6:145).

Por indução, um hábito se estabelece. Certas sensações, todas envolvendo uma ideia geral, são seguidas cada uma pela mesma reação; e uma associação se estabelece, por meio da qual aquela ideia geral passa a ser seguida uniformemente por aquela reação. (CP 6:145) ${ }^{28}$

Entretanto, a ação mental não é determinística ou puramente mecânica, pois, por mais que esteja orientada por hábitos, ela possui elementos de imprevisibilidade e espontaneidade:

De qualquer maneira que a mente tenha reagido sob uma dada sensação, dessa maneira é mais provável que reaja novamente; se isso, entretanto, fosse uma necessidade absoluta, os hábitos se tornariam rígidos e inerradicáveis e, não sobrando espaço para a formação de novos hábitos, a vida intelectual chegaria rapidamente ao fim. Assim, a incerteza da lei mental não é um mero defeito dela, mas, ao contrário, sua essência. (CP 6:148). ${ }^{29}$

Segundo Peirce, o princípio do crescimento é um elemento primordial do universo e existe graças ao acaso. O universo, por sua vez, é governado pela lei da mente, qual seja, a tendência a adquirir hábitos ou leis universais.

Ao defender a existência da continuidade entre todas as coisas, Peirce indica sua rejeição ao dualismo cartesiano, ou seja, à divisão entre mente e matéria (SANTAELLA, 2002). Entre os tipos de monismo possíveis, ele desconsidera o neutralismo e o materialismo, recorrendo ao idealismo objetivo ${ }^{30}$ : "a única teoria inteligível do universo é a do idealismo objetivo, em que a matéria é mente estéril, hábitos inveterados tornandose leis físicas" (CP 6:25). ${ }^{31}$ Uma vez que não há separação entre mente e matéria, Peirce afirma que a matéria não é algo morto, mas “mente limitada por hábitos” (PEIRCE, 1892,

\footnotetext{
28 "By induction, a habit becomes established. Certain sensations, all involving one general idea, are followed each by the same reaction; and an association becomes established, whereby that general idea gets to be followed uniformly by that reaction. (CP 6.145)"

29 "In whatever manner the mind has reacted under a given sensation, in that manner it is the more likely to react again; were this, however, an absolutenecessity, habits would become wooden and ineradicable and, no room being left for the formation of new habits, intellectual life would come to a speedy close. Thus, the uncertainty of the mental law is no mere defect. of it, but is on the contrary of its essence. (CP 6.148)."

${ }^{30}$ Para um aprofundamento sobre o idealismo objetivo de Peirce e sua visão cosmológica do universo, recomendamos a leitura da obra Kósmos Noetós: a Arquitetura Metafísica de Charles S. Peirce (IBRI, 2015).

31 "The one intelligible theory of the universe is that of objective idealism, that matter is effete mind, inveterate habits becoming physical laws." (CP 6:25).
} 
p. 557). Embora ainda haja vida, Peirce defende que a matéria não tem a espontaneidade observada na mente:

A verdade é que a mente não está sujeita à "lei" no mesmo sentido rígido que a matéria está. Ela só experimenta forças suaves que apenas a tornam mais propensa a agir de uma determinada maneira do que seria de outra forma. Sempre resta uma certa quantidade de espontaneidade arbitrária em sua ação, sem a qual ela estaria morta. (PEIRCE, 1892, p. 554; CP 6:148). ${ }^{32}$

Cabe destacar que o conceito de mente na filosofia peirceana não se reduz à mente humana. Peirce se afasta de uma abordagem psicologista da mente, uma vez que seu Sinequismo busca uma explicação geral para os processos evolutivos do universo, dos quais a mente humana também emergiu (ESPOSITO, 2005, p. 11). Assim, Santaella (2002, p. 103) pontua que "no contexto metafísico do sinequismo, mente é sinônimo de continuidade, é a tendência do universo para a aquisição de hábitos. No contexto lógico da semiótica, mente é sinônimo de semiose. Mente, portanto, é continuidade e semiose".

A doutrina sinequista oferece caminhos metodológicos para a pesquisa, conforme destaca Esposito (2005, p. 2): “do lado metodológico, o sinequismo é uma máxima para buscar conexões e camadas contínuas entre entidades ou eventos aparentemente desconectados". ${ }^{33}$ Para isso, deve-se considerar que o Sinequismo defende que o universo está em evolução contínua. Como explica Peirce, "um verdadeiro continuum é algo cujas possibilidades de determinação nenhuma multidão de individuais pode esgotar" (CP 6:170). ${ }^{34}$ Ainda segundo o autor, a doutrina da continuidade evita hipóteses de que algo seja inexplicável (CP 6:171). Entretanto, como explicar fenômenos que parecem inexplicáveis? Peirce indica que o caminho é fazer generalizações daquilo que a experiência nos impõe, não com o objetivo de encontrar uma resposta definitiva, mas porque "é apenas na medida em que os fatos podem ser generalizados que eles podem ser entendidos." (CP 6:173). ${ }^{35}$ Peirce prossegue, acrescentando que o Sinequismo "não é uma

\footnotetext{
32 "The truth is, the mind is not subject to "law" in the same rigid sense that matter is. It only experiences gentle forces which merely render it more likely to act in a given way than it otherwise would be. There Always remains a certain amount of arbitrary spontaneity in its action, without which it would be dead. (PEIRCE, 1892, p. 554; CP 6.148).”

33 "On the methodological side synechism is a maxim to look for connections and continuous strata between seemingly disconnected entities or events." (ESPOSITO, 2005, p. 2).

34 "A true continuum is something whose possibilities of determination no multitude of individuals can exhaust." (CP 6:170).

35 " $t$ is only so far as facts can be generalized that they can be understood;" (CP 6.173).
} 
doutrina metafísica última e absoluta; é um princípio regulador da lógica, prescrevendo que tipo de hipótese é adequada para se entreter e examinar" (CP 6:173). ${ }^{36}$

Isto posto, pontuamos que, na análise de autorrepresentações em ambientes digitais, o Sinequismo evidencia a necessidade de se investigar as possíveis conexões ou continuidades entre diferentes elementos na geração de sentidos. Para a nossa pesquisa, cabe acrescentar ainda uma breve apresentação de outra doutrina da Metafísica Peirceana, o Falibilismo, que fundamenta a falibilidade de nossas interpretações: "o falibilismo é a doutrina de que nosso conhecimento nunca é absoluto, mas sempre nada, por assim dizer, em um continuum de incerteza e de indeterminação" (CP 1:171). ${ }^{37}$ De acordo com Peirce, todo conhecimento é falível e provisório, ou seja, não se pode chegar a certezas absolutas. Entretanto, observamos que o Falibilismo é diferente do ceticismo:

Mas seria um equívoco sobre a doutrina do falibilismo supor que isso significa que duas vezes dois provavelmente não é exatamente quatro. Como já observei, não é meu propósito duvidar que as pessoas geralmente podem contar com precisão. Nem o falibilismo diz que os homens não podem atingir um conhecimento seguro das criações de suas próprias mentes. Não afirma nem nega isso. Diz apenas que as pessoas não podem atingir a certeza absoluta a respeito de questões de fato. (CP 1.149). ${ }^{38}$

Uma vez que o universo está em constante evolução, nada é definitivo e nenhuma explicação pode ser aceita como final. Assim, embora a generalidade seja a única forma de compreender a realidade, ela nunca poderá dar conta de explicar de forma exata todo o dinamismo e a diversidade do real. É a partir desta perspectiva que abordamos o nosso objeto de pesquisa.

\subsection{O self é um signo: a subjetividade à luz da Semiótica}

Como demonstramos até aqui, a Semiótica Peirceana é uma teoria geral, formal e antirracionalista. Ao longo de sua trajetória, Peirce afastou seus estudos de uma

\footnotetext{
36 "Synechism is not an ultimate and absolute metaphysical doctrine; it is a regulative principle of logic, prescribing what sort of hypothesis is fit to be entertained and examined." (CP 6.173).

37 "For fallibilism is the doctrine that our knowledge is never absolute but always swims, as it were, in a continuum of uncertainty and of indeterminacy. Now the doctrine of continuity is that all things so swim in continua." (CP 1:171).

38 “'“But it would be quite misunderstanding the doctrine of fallibilism to suppose that it means that twice two is probably not exactly four. As I have already remarked, it is not my purpose to doubt that people can usually count with accuracy. Nor does fallibilism say that men cannot attain a sure knowledge of the creations of their own minds. It neither affirms nor denies that. It only says that people cannot attain absolute certainty concerning questions of fact." (CP 1.149).
} 
abordagem psicologista em prol de uma ciência normativa que pudesse ser aplicada a todos os tipos de processos semióticos, e não apenas àqueles relacionados à mente humana. Peirce evidencia esse esforço no seguinte trecho:

Devemos começar obtendo noções diagramáticas de signos dos quais retiramos, a princípio, toda referência à mente; e depois de termos tornado essas ideias tão distintas quanto nossa noção de um número primo ou de uma linha oval, podemos então considerar, se necessário, quais são as características peculiares de um signo mental e, de fato, podemos dar uma definição matemática de uma mente no mesmo sentido em que podemos dar uma definição matemática de uma linha reta. (MS L75:143-147). ${ }^{39}$

Entretanto, isso não significa que o sujeito deva ser excluído da investigação Semiótica. O próprio Peirce afirmou, de modo literal, que "o homem é um símbolo" (CP $7: 583)$.

Conforme argumenta Colapietro (2014), a Semiótica fornece subsídios para a compreensão da subjetividade humana. Para o autor, a Teoria Geral dos Signos aponta para a possibilidade de conceber o self (eu, em uma das traduções possíveis da palavra em português) de uma maneira mais ampla, na medida em que este pode ser compreendido como processo, resultado e agente da prática sígnica. Assim, "a exploração da natureza e variedades da semiose (ou ação do signo) leva, em vez de descartar, a uma teoria geral do sujeito humano" (COLAPIETRO, 2014, p. 66). O self semiótico estaria no entrelaçamento entre as relações sociais e sua autonomia enquanto agente atuante no mundo.

Entendemos que a análise dos processos de autorrepresentação no ambiente digital passa necessariamente pela compreensão da subjetividade. Nesse sentido, este subcapítulo apresenta o sujeito a partir da Semiótica e, em seguida, faz uma breve discussão sobre o eu e suas autorrepresentações. Antes, porém, de prosseguirmos com a discussão sobre a subjetividade à luz da Semiótica Peirceana, cabe esclarecer nossas opções terminológicas, visto que esta era uma preocupação constante de Peirce e é impossível abordar sua obra sem levar em conta este aspecto. Como destacou o autor:

\footnotetext{
39 "We must begin by getting diagrammatic notions of signs from which we strip away, at first, all reference to the mind; and after we have made those ideas just as distinct as our notion of a prime number or of an oval line, we may then consider, if need be, what are the peculiar characteristics of a mental sign, and in fact may give a mathematical definition of a mind in the same sense in which we can give a mathematical definition of a straight line." (MS L75.143-147).
} 
A primeira regra de bom gosto ao escrever é usar palavras cujos significados não serão mal interpretados; e se um leitor não conhece o significado das palavras, é infinitamente melhor que ele saiba que não os conhece. Isso é particularmente verdadeiro em lógica, que consiste inteiramente, quase se poderia dizer, na exatidão do pensamento. (PEIRCE, 2017, p. 41).

Assim, assinalamos que a palavra self será aqui apresentada segundo a grafia original do inglês, considerando-se a nota do tradutor do livro O self semiótico (WILEY, 1996), que aponta para a impossibilidade de traduzi-la de maneira exata ao português. A grafia em inglês também foi mantida na tradução de Peirce e a abordagem do self: uma perspectiva semiótica sobre a subjetividade humana (COLAPIETRO, 2014). De acordo com o dicionário Oxford, self significa "o ser essencial de uma pessoa que a distingue dos outros, especialmente considerado como objeto de introspecção ou ação reflexiva" (SELF, 2019). ${ }^{40}$

Aqui, a palavra self é invocada com o intuito de discutir a subjetividade humana e, nesse sentido, ela também será relacionada a termos como eu e sujeito. Ponderamos, entretanto, que a palavra self não deve ser tomada como ego, termo relacionado à psicanálise de Freud (1856-1939). Em relação à palavra sujeito, ponderamos que ela deve ser lida levando-se em consideração que a abordagem semiótica da subjetividade busca ir um pouco além da simples subordinação do ser humano ao contexto, reconhecendo em alguma medida a sua agência. Por fim, ressaltamos que o self não deve ser confundido com o conceito de identidade, que será tomado aqui em consonância com Wiley (1996) e esclarecido ao longo desta seção. Outrossim, faremos uma discussão do self com vistas a desvendar os processos de comunicação e autorrepresentação em redes sociais digitais.

As noções ocidentais de sujeito e subjetividade foram herdadas do filósofo francês René Descartes (1596-1650) e estiveram subjacentes às teorias sociais e políticas ocidentais por alguns séculos, como pontua Santaella (2004a). Grosso modo, o cartesianismo definiu o humano em duas substâncias, o corpo e a mente, indicando que a essência do ser está no pensamento. Ao dar prevalência à mente no processo de constituição do eu, Descartes apresentou um sujeito autocentrado.

Os questionamentos das noções de sujeito tiveram início com Marx, Freud, Nietzsche e Heidegger e persistiram a partir de meados do século XX (TADEU DA SILVA, 2000, apud SANTAELLA, 2004a). Santaella (2004b) destaca que Peirce também

\footnotetext{
40 "A person's essential being that distinguishes them from others, especially considered as the object of introspection or reflexive action." (SELF, 2019)
} 
dedicou esforços à crítica da filosofia cartesiana. Entretanto, o objetivo dele era desenvolver uma nova metodologia das ciências. Nesse sentido, a objeção de Peirce foi direcionada à noção de intuição, para a qual propôs um método alternativo baseado no conceito de pensamento como signo. Como resultado,

[...] Peirce não só fez ruir o edifício diádico de Descartes colocando em seu lugar uma lógica ternária, mas também fez erguer-se dos interiores dessa lógica uma nova concepção de ser humano que, por si só, questiona o ego cartesiano de uma maneira arrasadora só comparável à demolição desse conceito provocada por Freud (SANTAELLA, 2004b, p. 24, itálico nosso).

Retornando à afirmação de que o homem é um signo (CP 5.314; CP 7.583), vamos elucidar de que maneira ela pode ser compreendida. Colapietro (2014) esclarece que a abordagem do self está contida na Teoria Geral dos Signos de Peirce, embora encontrese de certa forma implícita ao longo da vasta produção do filósofo. Deste modo, Colapietro desvenda as concepções de self por meio da discussão de diferentes artigos e fragmentos da obra do autor, levando em consideração as evoluções no pensamento de Peirce ao longo de sua carreira.

Devido à impossibilidade de ler e analisar toda a vasta obra de Peirce durante o curto período do mestrado, tarefa à qual os schollars se dedicam durante décadas, adotamos aqui os caminhos indicados por Colapietro (2014). A princípio, o autor identifica três momentos importantes para a teoria semiótica do self: o primeiro está representado na série de artigos publicados no The Journal of Speculative Philosophy entre 1867-1868; o segundo, em cinco artigos publicados no The Monist a partir de 1891; e o terceiro, relacionado aos últimos estudos sobre o pragmaticismo, após 1900 (COLAPIETRO, 2014, p. 113). Em consonância com essas considerações, realizaremos a discussão da subjetividade humana e de suas autorrepresentações.

Ainda nos primórdios de seu sistema filosófico, Peirce refutou o subjetivismo de Descartes e propôs uma alternativa para a origem do conhecimento (ROMANINI, 2006, p. 36). No artigo Algumas Consequências de Quatro Incapacidades, publicado originalmente em 1868, Peirce recusa a ideia de que o conhecimento está fundado em uma dúvida artificial:

Não podemos começar pela dúvida completa. Devemos começar com todos os preconceitos que realmente temos quando encetamos o estudo da filosofia.[...] No decorrer de seus estudos, é verdade, uma pessoa 
pode achar razões para duvidar daquilo em que começou acreditando; mas neste caso ela duvida porque tem uma razão positiva para tanto, e não em virtude da máxima cartesiana. Não pretendemos duvidar, filosoficamente, daquilo de que não duvidamos em nossos corações. (PEIRCE, 2017, p. 260).

Nesse sentido, ele aponta que a cognição é um processo dinâmico e não linear, que parte de preconceitos e testes de hipóteses na realidade:

Individualmente, não podemos razoavelmente esperar atingir a filosofia última que perseguimos; só podemos procura-la, portanto, para a comunidade dos filósofos. Por conseguinte, se mentes disciplinadas e imparciais examinarem cuidadosamente uma teoria e se recusarem a aceita-la, isto deveria criar dúvidas na mente do próprio autor da teoria. (PEIRCE, 2017, p. 260, itálico do autor).

Em outras palavras, Peirce indica que o conhecimento não pode ser reduzido à conjectura de uma pessoa, mas deve passar pelo crivo de outras, em uma postura radicalmente contrária à Descartes: “o ‘eu’ no famoso ‘eu penso, logo existo' - não é algo que intuímos direta e infalivelmente, mas algo que é adquirido através da interação com os outros." (WAAL, 2006, p. 152). ${ }^{41}$

Peirce (2017, p. 261) ainda rebate a ideia de introspecção, argumentando que os conhecimentos derivam de fatos externos; afirma que toda cognição é fruto de cognições anteriores; e acrescenta que não se pode pensar sem signos. Conforme sugere o autor, os pensamentos só podem ocorrer por meio de signos pois, quando pensamos, tudo o que está presente à consciência está no lugar de outra coisa - se pensamos em um cachorro, por exemplo, o que está presente à mente é um signo que representa tal animal. Romanini (2006, p. 39-40) lembra que a tese de que toda cognição deve ser precedida por outra cognição ad infinitum é abandonada por Peirce em 1885, quando ele descobre o papel do índice como indicador capaz de estabelecer uma conexão material com o assunto que denota.

Ao criticar o cartesianismo e propor que o conhecimento só pode ser fundado a partir da experiência, Peirce evidencia as limitações do sujeito cartesiano, na medida em que este conclui coisas a partir de seus próprios pensamentos. Peirce, de maneira oposta, sugere que o sujeito é fruto de experiências externas, em um movimento de

\footnotetext{
41 'the 'I' in the famous 'I think, therefore I am' - is not something we intuit directly and infallibly, but something that is acquired through the interaction with others." (WAAL, 2006, p. 152)
} 
descentramento do mesmo, como observamos no excerto do artigo Questões Referentes a Certas Faculdades Reivindicadas pelo Homem, publicado pela primeira vez em 1868:

Uma criança ouve dizer que o fogão está quente. Mas não está, ela diz; e de fato aquele corpo central não está tocando o fogão, e frio ou quente só está aquilo que esse corpo toca. Mas ela toca o fogão, e descobre que aquele testemunho se confirma de um modo notável. Assim, ela se torna consciente da ignorância, e é necessário supor um eu ao qual essa ignorância pode ser inerente. Destarte, o testemunho dá o primeiro esboço da autoconsciência. (PEIRCE, 2017, p. 249).

O surgimento da autoconsciência está relacionado à confirmação ou à negação do testemunho de outros por meio da experiência da própria criança. Ou seja, o eu emerge do choque com a realidade e da constatação da ignorância diante de fatos externos. Por conseguinte, Peirce aponta que o self é falível, em oposição ao eu cartesiano, como fica evidenciado na seguinte passagem: "Em suma, o erro surge, e só se aplica com o pressuposto de um eu que é falível” (PEIRCE, 2017, p. 250).

Colapietro (2014, p. 115) chama a atenção para o fato de que Peirce reconhece que o corpo exerce papel essencial no processo de autoconsciência. Nesse sentido, a afirmação de que o "homem é um símbolo", presente no artigo Consciência e linguagem, de 1867, não deve ser confundida com uma suposta eliminação da importância do organismo humano. Ao comparar o homem à palavra, por exemplo, Peirce reconhece a diferença fisiológica e a relevância da experiência, ao apontar que o homem "é afetado pelos objetos" (PEIRCE, 2017, p. 307). Entretanto, no mesmo texto Peirce pondera que a materialidade não é o elemento mais importante na constituição do homem, ao fazer o seguinte questionamento: "mas estaremos encerrados numa caixa de carne e sangue?" (Ibid., p. 309). Para Colapietro, a descrição do homem como símbolo não nega a corporalização da mente, mas "teve a intenção de argumentar contra o reducionismo (isto é, contra qualquer posição que reduza o self ao status de uma coisa [7.591])" (COLAPIETRO, 2014, p.116, itálico do autor).

Assim, o self como signo emerge a partir da experiência e das práticas entrelaçadas, mas não pode ser limitado à materialidade. Por meio da percepção, o homem internaliza informações que passam a compor o self e que servirão de baliza para suas ações. A abordagem semiótica do self revela a sofisticação presente na teoria semiótica, que se recusa a qualquer forma de dualismo. Waal (2006) lembra que o corpo funciona 
como meio entre o self e o mundo, mas não é possível fazer uma separação entre pensamento e matéria, como propõe o cartesianismo:

Como toda interação com o mundo é mediada por um único corpo, e como a mente é tanto um aspecto desse corpo quanto um produto das interações desse corpo com seu ambiente, o corpo pode ser visto como dirigindo a mente à unidade e à singularidade, incluindo uma unidade de consciência. (WAAL, 2006, p. 153). ${ }^{42}$

A partir de signos que são corporificados na mente, o homem é capaz de ultrapassar a materialidade do corpo e levar adiante o que está em seu interior:

Quando eu, isto é, meus pensamentos, entro em outro homem, não levo comigo necessariamente todo meu ser, mas o que levo de fato é a semente da parte que não estou levando - e se carrego a semente de toda minha essência, carrego a de todo meu ser concreto e potencial. (PEIRCE, 2017, p. 310).

Nesse sentido, a generalidade dos signos permite que a comunicação se estabeleça entre duas ou mais pessoas, tendo em vista que eles servem como mediadores entre o intelecto e a realidade exterior.

Colapietro (2014) enfatiza que neste primeiro momento do desenvolvimento da abordagem do self, Peirce já oferece uma interpretação semiótica da consciência humana e do sujeito da consciência, como pode ser observado no seguinte trecho:

[...] sempre que pensamos, temos presente na consciência algum sentimento, imagem, concepção ou outra representação que serve como signo. Mas segue de nossa própria existência (o que está provado pela ocorrência da ignorância e do erro) que tudo o que está presente a nós é uma manifestação fenomenal de nós mesmos. [...] Portanto, quando pensamos, nós mesmos, tal como somos naquele momento, surgimos como um signo. (PEIRCE, 2017, p. 269, itálico nosso).

O homem, enquanto ser pensante, é um signo, pois, como havia defendido Peirce, o pensamento só pode se dar por meio de signos e a ação dos signos é caracterizada como um processo dinâmico e contínuo, em que signos remetem a outros signos.

Cabe ressaltar que a argumentação de Peirce de que o conhecimento deve ter origem em dúvidas genuínas e que estas, por sua vez, deveriam ser submetidas à

\footnotetext{
42 "Since all interaction with the world is mediated though a single body, and since the mind is both an aspect of that body and a product of that body's interactions with its environment, the body can be seen as steering the mind to unity and singularity, including a unity of consciousness." (WAAL, 2006, p. 153)
} 
experiência e à comunidade, já sugere a ideia de que o sujeito na perspectiva semiótica é concebido como um ser constituído em relação a outros. Segundo Colapietro (2014, p. 66), “sob a perspectiva semiótica, estamos sempre já entre outros, bem como entre significados; de fato, alteridade e significado dão-se juntos em nossa experiência de nós mesmos como seres incluídos em uma rede de relações [...]". Isso não significa que a Semiótica negue a unicidade do self; entretanto, sua existência única só pode ser reconhecida a partir da relação com o outro, como destaca Colapietro (2014). O referido autor ainda argumenta que o descentramento do sujeito não leva à exclusão do agente, mas à "recuperação de atores de carne e osso que estão continuamente definindo a si próprios através de seu relacionamento de trocas com o mundo natural e os outros" (COLAPIETRO, 2014, p. 29). Em outras palavras, a posição anticartesiana de Peirce dá relevância ao papel das práticas, dos contextos e das relações interpessoais na constituição do sujeito.

O segundo momento da abordagem semiótica da subjetividade é marcado pelo desenvolvimento da cosmologia peirceana, em especial da doutrina do Sinequismo. Em oposição à concepção de William James (1842-1910) da consciência humana, a qual pressupõe o isolamento dos pensamentos, Peirce propõe a comunicação como lei (COLAPIETRO, 2014, p. 78-79). Colapietro (2014, p. 127) destaca que essa postura está relacionada à abordagem sinequista, que rejeitaria rupturas entre o self e o outro em prol da continuidade: "Para Peirce, então, o self individual é, em seu ser mais íntimo, não uma esfera privada, mas um agente comunicativo".

No artigo A Lei da Mente, publicado em 1892, Peirce discorre sobre o desenvolvimento da personalidade, defendendo que este se dá a partir da conexão de ideias. Essa explanação oferece subsídios para a compreensão da subjetividade humana a partir da perspectiva semiótica:

[...] de acordo com o princípio que estamos traçando, uma conexão entre ideias é em si uma ideia geral, e que uma ideia geral é um sentimento vivo, é claro que demos pelo menos um passo apreciável em direção ao entendimento de personalidade. Essa personalidade, como qualquer ideia geral, não é algo para ser apreendido em um instante. Tem que ser vivido no tempo; nem pode qualquer tempo finito abrangêlo em toda a sua plenitude. [...] Mas a palavra coordenação implica um pouco mais do que isso; implica uma harmonia teleológica de ideias e, no caso da personalidade, essa teleologia é mais do que uma mera busca intencional de um fim predeterminado; é uma teleologia do desenvolvimento. Este é o caráter pessoal. Uma ideia geral, viva e consciente agora, já é determinante dos atos no futuro, a um ponto em 
que não é agora consciente. Essa referência ao futuro é um elemento essencial da personalidade. Se os fins de uma pessoa já estivessem explícitos, não haveria espaço para desenvolvimento, para crescimento, para vida; e conseqüentemente não haveria personalidade. A mera realização de propósitos predeterminados é mecânica. (PEIRCE, 1892, p. 556, itálico nosso). ${ }^{43}$

Ao afirmar que a personalidade só pode existir em referência ao futuro, e que não pode ser captada em um instante, Peirce evidencia, mais uma vez, que o self não é uma instância imutável, estática. O self "deve ser vivido no tempo", ou seja, é impossível compreendê-lo em sua totalidade a partir de um ponto específico. Aqui, cabe apresentarmos mais uma definição de signo, pois ela nos ajuda a compreender a caracterização da personalidade descrita por Peirce:

Um Signo é tudo aquilo que está relacionado com uma Segunda coisa, seu Objeto, com respeito a uma Qualidade, de modo tal a trazer uma Terceira coisa, seu Interpretante, para uma relação com o mesmo Objeto, e de modo tal a trazer uma Quarta para uma relação com aquele Objeto na mesma forma, ad infinitum. Se a série é interrompida, o Signo, por enquanto, não corresponde ao caráter significante perfeito. (PEIRCE, 2017, p.28).

Os signos se desenvolvem por meio de relações triádicas ad infitinum e a interrupção dessa série impossibilita que o signo realize todas as suas possibilidades significantes, assim como uma pessoa que tenha seus fins já definidos não tem espaço para se desenvolver e, por conseguinte, não haveria possibilidade para a emergência da personalidade. Desse modo, o self é um signo na medida em que está em constante transformação.

A terceira fase apontada por Colapietro (2014) no desenvolvimento da abordagem peirceana do self é marcada pelo amadurecimento do pragmatismo e pelo reconhecimento da habilidade do ser humano de exercer influência direta sobre a formulação de hábitos

\footnotetext{
43 " [...] according to the principle which we are tracing out, a connection between ideas is itself a general idea, and that a general idea is a living feeling, it is plain that we have at least taken an appreciable step toward the understanding of personality. This personality, like any general idea, is not a thing to be apprehended in an instant. It has to be lived in time; nor can any finite time embrace it in all its fulness. [...] But the word coordination implies somewhat more than this; it implies a teleological harmony in ideas, and in the case of personality this teleology is more than a mere purposive pursuit of a predeterminate end; it is a developmental teleology. This is personal character. A general idea, living and conscious now, it is already determinative of acts in the future, to an extent to which it is not now conscious. This reference to the future is an essential element of personality. Were the ends of a person already explicit, there would be no room for development, for growth, for life; and consequently there would be no personality. The mere carrying out of predetermined purposes is mechanical. (PEIRCE, 1892, p. 556, itálico nosso)."
} 
por meio da autonomia e do autocontrole. Nesse terceiro momento, Peirce sugere que o self é dialógico. Isso pode ser observado no artigo O Que é Pragmatismo, publicado originalmente em 1905:

Há aqui duas coisas muito importantes de que nós devemos certificar e lembrar. A primeira é que uma pessoa não é, em absoluto, um individual. Seus pensamentos são aquilo que ela está 'dizendo a si mesma', ou seja, aquilo que está dizendo ao outro ego que está surgindo para a vida no fluxo do tempo. Quando raciocinamos, é esse ego crítico que estamos tentando persuadir; e todo pensamento, seja qual for, é um signo, e é fundamentalmente da natureza de linguagem. (PEIRCE, 2017, p. 290).

Como destaca Colapietro (2014, p. 142), o dialogismo manifesta-se no self consigo mesmo e no diálogo interpessoal do self com outros, em um movimento capaz de unir vários de uma sociedade a ponto de que esta síntese seja uma "pessoa frouxamente compactada", conforme continua Peirce:

\begin{abstract}
A segunda coisa a lembrar é que o círculo de sociedade de alguém (no sentido mais amplo ou mais estrito em que esta frase possa ser entendida) é uma espécie de pessoa frouxamente compactada e, sob alguns aspectos, de um grau mais elevado do que a pessoa de um organismo individual. (PEIRCE, 2017, p. 290).
\end{abstract}

Segundo Santaella (2006, p. 128), o diálogo é possibilitado graças ao dialogismo dos signos, pois só eles "são capazes de transmutar sua materialidade de modo a apresentar uma materialidade que é própria dos signos internos do cérebro e uma outra materialidade fora do cérebro, nos signos externos que são coletivamente comunicáveis."

Colapietro (2014) sugere que a noção semiótica de self oferece uma alternativa entre o self cartesiano autocentrado e a proposta de estruturalistas e pós-estruturalistas, na medida em que a tendência à descentralização do sujeito nesta última levaria à eliminação do agente:

O sujeito, em nosso sentido do termo, é um ser profundamente dividido e culturalmente sobredeterminado; e, além disso, um ser histórico e encarnado. Ademais, seja qual for o grau de liberdade e consciência alcançado pelo sujeito, sua vida é essencialmente dramática e seus haveres são radicalmente inseguros. Não podemos entender completamente quaisquer dessas dimensões fundamentais da subjetividade humana, salvo a partir de uma elaborada teoria de processos semióticos. (COLAPIETRO, 2014, p. 83-84) 
Em outras palavras, a Semiótica permite uma compreensão das diversas camadas da subjetividade humana sem incorrer ao dualismo. Nessa perspectiva, a abordagem semiótica da subjetividade humana é situada histórica e socialmente sem, contudo, apagar uma certa autonomia do self.

Para Wiley (1996), a abordagem semiótica do self permite a compreensão de uma natureza humana universal, ou seja, de um "self sui generis". O autor argumenta que a caracterização do self como inerentemente semiótico evita "reduções ascendentes", quando o self é reduzido às interações e convenções socioculturais, e "reduções descendentes", quando o selfé compreendido apenas em suas funções físicas e biológicas. Ao considerar a afirmação de Peirce de que o self é um signo, Wiley defende que ela só pode ser compreendida considerando-se que o self é uma estrutura que abarca diversos conteúdos: "o ato de conter, contudo, não é físico nem espacial, mas semiótico e significativo" (WILEY, 1996, p. 43). Como estrutura, o self seria algo genérico no qual estão contidos níveis como signos individuais (pensamentos) e complexos sistemáticos de signos, como etnia, classe, gênero e identidade sexual (WILEY, 1996, p. 30). Nesse sentido, a estrutura genérica do self seria maior do que as identidades:

As identidades particularizam e nos possibilitam reconhecer indivíduos, categorias, grupos e tipos individuais. Podem ser impostas do exterior, por meio de processos sociais, ou do interior, caso no qual são usualmente denominadas de autoconceitos [self-concepts]. (WILEY, 1996, p. 17).

Enquanto o self é um processo semiótico em constante evolução, as identidades são circunstanciais e emergem desse processo. Por conseguinte, "boas identidades são a ponte entre o self e o mundo. No entanto, se as identidades não são congênitas à pessoa, tanto psicologicamente quanto socialmente falando, elas podem criar bloqueios entre conteúdos e estrutura" (WILEY, 1996, p. 52). Compreendemos, assim, que as autorrepresentações da subjetividade por meio da construção de perfis na rede social Instagram podem ser consideradas identidades, uma vez que representam apenas fragmentos do self e surgem a partir de um processo pontual, circunscrito em um determinado contexto e orientado por certos propósitos. Essas identidades, por sua vez, estão sujeitas à variadas relações sígnicas que se dão no ambiente digital e que podem gerar diferentes significados.

Como signo, o self está em constante processo de desenvolvimento e crescimento. O self não é imutável, mas está em transformação contínua a partir da relação com o outro 
e esta, por sua vez, é sempre marcada pelo contexto histórico em que está inserida. O caráter significante do signo só se realiza a partir da semiose, um processo contínuo, dinâmico e sem final definido. Da mesma forma, considerando-se que o self é um signo, qualquer tentativa de apreendê-lo a partir de um ponto isolado é incompleta.

Conforme explicitado ao longo deste subcapítulo, o self tem a comunicação em sua essência, ou seja, o ser humano é um agente comunicativo. Nesse sentido, a abordagem semiótica da subjetividade demonstra a importância do campo da Comunicação, uma vez que as trocas comunicacionais fazem parte da ontologia do ser humano e o estudo dessas trocas tem grande relevância para a compreensão de processos sócio-históricos e das transformações do contexto contemporâneo. Além disso, a consideração do self semiótico possibilita a abordagem de diferentes nuances dos fenômenos comunicacionais, pois é preciso ponderar que os sujeitos são agentes e produtos da prática sígnica.

Colapietro (2019) destaca que a emergência e o desenvolvimento da subjetividade são processos complexamente mediados, uma vez que os signos fazem parte de nossa constituição, ou seja, eles não são apenas meios externos, mas fazem parte de nossa subjetividade e características internas. Sobre as possibilidades de autorrepresentação proporcionadas por ambientes digitais, o referido autor destaca que:

Nossa relação com o mundo é uma relação mediada semioticamente:
sempre pensamos em signos e nos tornamos um com os signos nos quais
nos baseamos (eles não são meios externos, mas características
constitutivas de nossa consciência semiótica). Da mesma forma, nosso
relacionamento é mediado tecnologicamente e é mediado de uma forma
que é inseparável da mediação semiótica. Tudo isso aponta para formas
de subjetividade e identidade nunca sonhadas antes das invenções e
inovações da era digital. (COLAPIETRO, 2019). ${ }^{44}$

Por conseguinte, a intensificação das comunicações mediadas pela tecnologia tem reflexos na subjetividade e nos processos de comunicação entre os sujeitos. Uma vez que a relação do self com o mundo é sempre mediada, as possibilidades de representação e mediação trazidas pelo ambiente digital somam-se a outras formas de mediação inerentes

\footnotetext{
44 "Our relationship to the world is a semiotically mediated relationship: we always think in signs and we come to be one with the signs on which we rely (they are not external means, but constitutive features of our semiotic consciousness). So, too, our relationship is technologically mediated and it is so mediated in a way that is inseparable from semiotic mediation. All of this points to forms of subjectivity and identity undreamt before the inventions and innovations of the digital age". (COLAPIETRO, 2019)
} 
à constituição da subjetividade: “A linguagem está tanto em nós quanto nós nela; e ela está em nós porque somos parte dela. O que é verdade para uma linguagem natural pode ser igualmente verdade para várias formas de tecnologia." (COLAPIETRO, 2019). ${ }^{45}$

Conforme indica Colapietro, as linguagens e outras ferramentas que medeiam a relação entre o self e o mundo também passam a se constituir, em alguma medida, como partes desse self. Assim, o estudo das autorrepresentações em ambientes digitais deve levar em consideração as lógicas envolvidas nesse ambiente e o papel que as tecnologias e outros sujeitos exercem na constituição do self e de suas representações na forma de identidades digitais. Estes temas serão discutidos no próximo capítulo.

45 "Language is as much in us as we are in it; and it is in us because we are of it. What is true of a natural language can be equally true of various forms of technologically." (COLAPIETRO, 2019) 


\section{O SELF NO AMBIENTE DIGITAL: AUTORREPRESENTAÇÕES NO CONTEXTO CONTEMPORÂNEO}

Neste capítulo discutimos os processos de autorrepresentação no ambiente digital, considerando que essas representações funcionam como formas de inserção do self nesse ambiente. Embora nosso recorte seja feito a partir de perfis profissionais criados intencionalmente na rede social Instagram, propomos uma avaliação mais ampla das dinâmicas presentes no espaço virtual, uma vez que entendemos que a criação e a circulação de sentidos envolvem interações complexas entre diferentes códigos, dados e atores interconectados, considerando-se o contexto, os controles exercidos pelas redes, as legislações que regem esse espaço e os possíveis interesses econômicos e políticos de empresas, pessoas e governos, etc.

Outrossim, o ambiente digital é composto por diversas linguagens e os processos de representação estão atrelados às lógicas computacionais. Nesse sentido, uma autorrepresentação no digital só pode ser construída com e apesar de todas essas circunstâncias, uma vez que o ambiente digital se constitui a partir dessas interconexões.

Sem a pretensão de nos aprofundarmos em todas as questões citadas acima, salientamos que é preciso considerar as diversas camadas e dinâmicas presentes no digital para compreendermos como esses processos estão relacionados às autorrepresentações, bem como identificar os limites de nossa análise. Na Semiótica Peirceana, os significados emergem das relações entre signos e, estes, por sua vez, podem pertencer a diferentes classes. Aqui, consideramos as autorrepresentações como conjuntos de signos em relação e, por isso, o mapeamento de todos os elementos da semiose é fundamental para a investigação.

\subsection{Digitalização: banco de dados, algoritmos e rede}

O ambiente digital é simbólico por excelência, uma vez que toda informação contida nele passa por um processo de codificação em linguagem computacional. É esse processo que permite que as informações sejam posteriormente acessadas por usuários em formato de fotos, vídeos, sons, textos, memes, hashtags etc., a partir de traduções operadas por interfaces (como as de redes sociais e outros sites), e se materializem por meio de telas de computadores, smartphones e tablets, entre outros. Assim, toda 
representação da subjetividade no ambiente digital está inscrita e só pode emergir a partir da codificação em linguagem computacional.

Comecemos, pois, por uma visão geral sobre os aspectos que envolvem a codificação do ambiente digital. Manovich (2001, p. 27-28) esclarece que esses ambientes, denominados por ele como "novas mídias", são formados por objetos compostos por códigos digitais, ou seja, representações numéricas que podem ser descritas matematicamente. Nesse sentido, essas representações seriam bancos de dados programáveis. A digitalização de informações é feita a partir da quantificação e da classificação dos dados, que podem posteriormente ser recombinados de inúmeras formas, em distintos contextos e momentos. Portanto, os signos presentes no ambiente digital pertencem à categoria fenomenológica da terceiridade, pois emergem a partir de regras, leis e modelos determinados pela natureza digital. Recordamos, entretanto, que a terceiridade engloba aspectos de primeiridade e secundidade. Assim, uma foto na rede social Instagram, por exemplo, não pode ser considerada apenas um ícone por sua suposta semelhança com o objeto que professa representar, tampouco pode-se destacar apenas seu componente indicial.

É certo que uma foto exibida na interface do Instagram possui elementos icônicos e indiciais, mas estes só podem alcançar possíveis intérpretes humanos porque tal foto passou por um processo de codificação e digitalização. Além disso, embora uma foto possa apresentar elementos icônicos, indiciais e simbólicos, é importante observar qual função ela desempenha na semiose. Isso significa que uma foto publicada em um jornal impresso pode funcionar de modo diferente caso seja compartilhada em uma rede social digital ou estampada em um muro de uma grande avenida.

Santaella e Nöth (2012) argumentam que as imagens sintéticas produzidas a partir de matriz algorítmica devem ser consideradas representações, assim como as pinturas e as imagens fotográficas. Entretanto, os autores destacam que o caráter desse tipo de representação é mais complexo:

As equações algébricas a serem processadas pelos computadores e que são passíveis de serem traduzidas nos pontos de luz da tela são matrizes numéricas ou representações de um modelo. A imagem sensível que aparece na tela, por sua vez, funciona como outro tipo de representação, mais indicial, da relação ponto a ponto do valor numérico com o pixel. Por fim, a imagem na tela é ainda um outro tipo de representação, mais icônica, quer dizer, é uma das aparências sensíveis possíveis do modelo que a gerou. (SANTAELLA, NÖTH, 2012, p. 164). 
Da mesma forma, todos os elementos de um perfil profissional no Instagram que podem ser visualizados na interface da rede por outros usuários - tais como textos, vídeos, fotos e links - passaram por digitalização. Nesse sentido, além de considerarmos as autorrepresentações do ponto de vista dos signos que se materializam nas telas, avaliando suas características icônicas, indiciais e simbólicas, deve-se considerar que esses elementos passaram por codificação em linguagem computacional.

Apesar do caráter aparentemente neutro, os bancos de dados são criados e valorados segundo determinados critérios e visões de mundo:

O processo de categorização é uma poderosa intervenção semântica e política: quais são as categorias, o que pertence a elas e quem decide como implementá-las na prática, são todas asserções poderosas sobre como as coisas são e como elas devem ser (BOWKER; STAR, 2000, apud GILLESPIE, 2018, p. 100). ${ }^{46}$

Nessa perspectiva, observamos que as ações realizadas no ambiente digital estão sujeitas, desde o princípio, aos vieses e às lógicas criadas por aqueles responsáveis por codificar esse ambiente.

Para Manovich (2015), o banco de dados é um novo gênero da cultura, na medida em que, diferentemente das narrativas, as coleções de dados não têm sequência linear e podem ser acessadas, cruzadas e correlacionadas de várias formas. Mas, para que esse mecanismo funcione, é necessário também a ação de algoritmos. Segundo Manovich (2015, p.11), “juntos, as estruturas de dados e os algoritmos são duas metades da ontologia do mundo, no ponto de vista de um computador".

De acordo com Gillespie (2014, p. 167), algoritmos são "procedimentos codificados para transformar inputs de dados em outputs desejáveis, com base em cálculos específicos". ${ }^{47} \mathrm{Ou}$ seja, eles funcionam a partir de regras que selecionam e agrupam certos dados de acordo com objetivos previamente definidos, interferindo no modo como as informações circulam no ambiente digital. Algoritmos, assim, podem ser definidos como um conjunto de ações capazes de processar dados - ou signos -, gerando certos resultados. O’Neil (2016) chama a atenção para os vieses contidos nos algoritmos ao destacar que “modelos são opiniões embutidas em matemática” (O’NEIL, 2016, p.

\footnotetext{
46 "Categorization is a powerful semantic and political intervention: what the categories are, what belongs in a category, and who decides how to implement these categories in practice, are all powerful assertions about how things are and are supposed to be." (BOWKER; STAR, 2000, apud GILLESPIE, 2018, p. 100) 47 "they are encoded procedures for transforming input data into a desired output, based on specified calculations". (GILLESPIE, 2014, p. 167).
} 
21). ${ }^{48}$ Segundo a referida autora, a promessa de objetividade e imparcialidade dos algoritmos esconde o fato de que eles são criados por pessoas e, nesse sentido, muitos carregam em suas codificações os preconceitos, mal-entendidos e vieses de seus criadores. Nessa perspectiva, O’Neil argumenta que esses modelos algorítmicos são simplificações e que "nenhum modelo pode incluir toda a complexidade do mundo real ou as nuances da comunicação humana" (O’NEIL, 2016, p. 20). ${ }^{49}$

De modo simplificado, Just e Latzer (2016, p. 239) definem algoritmos como "mecanismos de solução de problemas". ${ }^{50}$ Segundo os autores, algoritmos atuam a partir da aplicação de operações estatísticas que selecionam e atribuem relevância a um conjunto de dados. A proposta de classificação dos algoritmos feita por Latzer et al. (2014 apud JUST; LATZER, 2016, p. 240) com base na função deles oferece um panorama sobre as possíveis aplicações desses mecanismos: "busca (usados em buscadores como Google e Bing); recomendação (em serviços como Netflix); pontuação/score; previsão/prognósticos; observação/vigilância; alocação de publicidade (Google AdSesnse); produção de conteúdo; e agregadores (Google News).” As diversas aplicações da seleção algorítmica automatizada e a influência que ela vem assumindo na esfera social levam Just e Latzer (2016, p. 254) a defender que os algoritmos sejam avaliados do ponto de vista institucional, pois "eles influenciam não apenas o que pensamos, mas também como pensamos e, consequentemente, como agimos, comodelando a construção das realidades dos indivíduos". 51

Em artigo que discute a ética dos processos algorítmicos, Ananny (2015) traz contribuições para a compreensão do funcionamento desses procedimentos ao propor nomeá-los como "algoritmos de informação em rede" (do inglês networked information algorithms), que ele define como conjuntos de "[...] código computacional institucionalmente estabelecido, práticas humanas e lógicas normativas que criam, sustentam e significam relações entre pessoas e dados por meio de uma ação semiautônoma minimamente observável" (ANANNY, 2015, p. 7) . $^{52}$.

\footnotetext{
48 "Models are opinions embedded in mathematics". (O’NEIL, 2016, p. 21).

49 "No model can include all of the real world's complexity or the nuance of human communication". (O’NEIL, 2016, p. 20).

50 “Algorithms are problem-solving mechanisms". (JUST; LATZER, 2016, p. 239).

51 "They influence not only what we think about but also how we think about it and consequently how we act, thereby co-shaping the construction of individuals' realities". (JUST, LATZER, 2016, p. 254).

52 "I define an NIA as an assemblage (DeLanda 2006; Latour 2005) of institutionally situated computational code, human practices, and normative logics that creates, sustains, and signifies relationships among people and data through minimally observable, semiautonomous action." (ANANNY, 2015, p. 7).
} 
Ao pontuar que os algoritmos "criam" relações e têm ação "semiautônoma", ou seja, uma certa capacidade de agência, Ananny (2015) evidencia os complexos mecanismos envolvidos na semiose no ambiente digital, marcada pela interconexão entre ações humanas e elementos não-humanos. Sob esta ótica, Nöth (2001, p. 71) argumenta, em artigo sobre máquinas semióticas, que há uma continuidade nos processos semióticos entre sujeitos e sistemas técnicos: "as diferenças que restam entre a semiose humana e a da máquina são uma questão de grau.” A definição de algoritmos proposta por Ananny (2015) chama a atenção para o fato de que, embora os algoritmos sejam baseados em programações e códigos pré-definidos, eles não são regidos apenas por relações de causa e efeito - características da categoria fenomenológica da secundidade -, uma vez que seu funcionamento é marcado pela ação humana e pela possibilidade de que seus processos sejam reconfigurados de modos não totalmente previsíveis. Sem nos prolongarmos na discussão sobre as possibilidades de semiose maquínica, pontuamos, a partir dessas considerações, que é importante avaliar de que modo as lógicas algorítmicas do Instagram podem ter orientado ou influenciado a construção das autorrepresentações na rede, admitindo o fato de que não temos ferramentas capazes de observar diretamente a ação dos algoritmos.

Gillespie (2018, p. 110) reconhece o entrelaçamento entre os algoritmos e as táticas dos sujeitos em relação a eles, admitindo que os usuários podem tentar sensibilizar algoritmos para alcançar objetivos pessoais, como obter mais visibilidade ou facilitar a encontrabilidade de seu perfil em uma rede social, o que pode, inclusive, reconfigurar as programações iniciais dos mesmos. Haveria, assim, um "ciclo recursivo entre os cálculos do algoritmo e os 'cálculos' das pessoas" (Ibid., p. 110). Nesse sentido, buscaremos entender em que medida as autorrepresentações estão relacionadas a possíveis tentativas de reconfigurar os algoritmos do Instagram.

Embora esse "ciclo recursivo" pressuponha a participação ativa dos usuários e esteja em movimento constante, o referido autor afirma que a presença cada vez mais recorrente de algoritmos no cotidiano das pessoas evidencia a incorporação de lógicas computacionais nos processos de sociabilidade contemporâneos. Por conseguinte, Gillespie (2018) alerta que o aumento no uso de algoritmos na seleção de informações que supostamente devem ser consideradas mais relevantes para as pessoas requer a observação das decisões humanas e corporativas que estão por trás deles, pois, 
à medida que adotamos ferramentas computacionais como nossos principais meios de expressão e passamos a fazer não só da matemática mas de toda a informação digital, passamos a sujeitar o discurso e o conhecimento humano a essas lógicas procedimentais que sustentam toda a computação. (GILLESPIE, 2018, p. 97, itálico do autor).

Para se ter uma ideia de como a seleção algorítmica ocorre, pontuamos que grandes corporações como Google, Facebook, Amazon e Microsoft utilizam algoritmos para classificar informações que transitam por seus serviços e assim realizar o que Pariser (2012) denomina "personalização" dos conteúdos que serão entregues a cada usuário.

A partir de informações pessoais oferecidas voluntariamente por usuários e de rastros de navegação coletados pelas redes com ou sem o conhecimento de usuários (como localização e buscas realizadas), essas empresas analisam as supostas preferências de cada pessoa e, com isso, fazem previsões sobre suas próximas escolhas. Além disso, com base nesses perfis traçados, os sistemas determinam os conteúdos que cada pessoa deve receber de acordo com suas supostas crenças e gostos, gerando a chamada "bolha dos filtros", em que pessoas com opiniões e perfis semelhantes tendem a receber conteúdos parecidos (PARISER, 2012, p. 14).

Esse mecanismo de personalização aponta para uma tentativa de gerar representações do self que estejam alinhadas aos objetivos econômicos de empresas, uma vez que o enquadramento do self a determinados parâmetros facilitaria negócios como a venda de anúncios personalizados, entre outros. Um exemplo disso pode ser observado no Instagram. Em sua política de dados (INSTAGRAM, 2019a), a empresa informa que armazena dados incluídos voluntariamente pelo usuário e ainda dados e metadados coletados de forma contínua, a partir do momento em que o usuário cria uma conta. Esses dados abarcam localização, marca do dispositivo usado, operadora, pessoas com as quais o dono da conta se comunica e interações realizadas no perfil, entre outros.

Com as informações coletadas e tratadas, o Instagram faz inferências sobre as possíveis características e gostos do usuário aos quais os dados pertencem, ou seja, a rede social cria uma espécie de representação do sujeito, à qual são atribuídos certos significados, conforme explica a empresa: "associamos as informações sobre as tuas atividades em diferentes dispositivos e Produtos do Facebook para fornecer uma experiência mais personalizada e consistente em todos os Produtos do Facebook que utilizas, onde quer que seja".(INSTAGRAM, 2019a). Embora não cite a palavra "algoritmo", o Instagram indica que faz a seleção de conteúdos e posterior personalização 
da experiência do usuário, direcionando, assim, os conteúdos aos quais cada pessoa terá acesso. Posteriormente, as informações coletadas e tratadas são usadas nos negócios da empresa:

\begin{abstract}
Utilizamos as informações que temos para fornecer os nossos Produtos, incluindo para personalizar funcionalidades e conteúdos (incluindo o teu Feed de Notícias, o Feed do Instagram, o Instagram Stories e os anúncios) e para fazer-te sugestões (como grupos ou eventos nos quais possas estar interessado ou tópicos que possas pretender seguir) dentro e fora dos nossos Produtos. Para criarmos Produtos personalizados que sejam únicos e relevantes para ti, utilizamos as tuas ligações, preferências, interesses e atividades com base nos dados que recolhemos e que nos são fornecidos por ti e por terceiros (incluindo dados com proteções especiais que optas por fornecer); como utilizas e interages com os nossos Produtos; e as pessoas, locais ou conteúdos aos quais estás ligado e nos quais estás interessado dentro e fora dos nossos Produtos. (INSTAGRAM, 2019a).
\end{abstract}

Adicionalmente, a chamada "bolha dos filtros", criada pela tentativa de fazer previsões sobre os gostos pessoais dos usuários dessas redes, pode contribuir para o estreitamento das possibilidades de narrativas da subjetividade, uma vez que os sujeitos ficam expostos principalmente a informações alinhadas às suas crenças e hábitos, enquanto informações conflitantes, que poderiam promover um choque com a realidade, perdem espaço. Conforme alerta Pariser (2012, p. 77), a personalização dos conteúdos tem consequências em nossos processos cognitivos, pois os filtros (ou algoritmos) podem "[...] limitar a variedade de coisas às quais somos expostos, afetando assim o modo como pensamos e aprendemos. Podem perturbar o delicado equilíbrio cognitivo que nos ajuda a tomar boas decisões e a ter novas ideias". Nessa perspectiva, acreditamos que uma autorrepresentação poderia ser impactada na medida em que as informações às quais os usuários têm acesso sejam limitadas por uma seleção prévia feita por algoritmos.

Floridi (2014) indica que as tecnologias da informação e da comunicação contribuem para uma sobrevalorização do digital e para o surgimento do que ele denomina como "experiência onlife", caracterizada pelo apagamento das fronteiras entre on-line e offline. Assim, à medida em que as pessoas permanecem mais tempo conectadas, a experiência sensível vai perdendo espaço e, em lugar da corporeidade, surge o que o autor denomina "tipificação dos indivíduos" (FLORIDI, 2014, p. 57), processo em que pessoas passam a conceituar-se segundo padrões ou moldes, tais como gênero, religião, educação, etc. Esse processo é alimentado pelo constante ajuste das autorrepresentações dos sujeitos aos parâmetros e lógicas das redes, o que pode excluir, aos poucos, as particularidades de 
cada self. Esse contexto conduz ao que Floridi $(2014,2015)$ chama de "cultura proxy", na qual há a possibilidade de que as representações no ambiente digital tornem-se símbolos vazios, sem conexão com a realidade.

[...] uma "cultura proxy" pode se tornar uma cultura substituta, em que proxies tornam-se meros substitutos que não apenas escondem suas referências originais [...], mas tornam difícil ou mesmo impossível alcançá-las, porque as substituem totalmente, sem qualquer ligação residual a uma realidade alternativa. Um mundo em que não há café de chicória não é um mundo melhor, mas um mundo em que há apenas café de chicória é um mundo pior e mais superficial. (FLORIDI, 2015, p. 490). ${ }^{53}$

Em outras palavras, os chamados proxies não teriam mais conexão com seus supostos objetos, mas seriam substitutos deles, em um processo que levaria ao descolamento da experiência sensível em prol da repetição de padrões digitais.

Para Floridi (2014, p. 73-74), a "cultura proxy" pode alterar o modo como o self percebe a si mesmo, pois, à medida em que a subjetividade é moldada, representada em perfis e submetida às lógicas próprias do meio digital, o sujeito tem a possibilidade de observar seu avatar e fazer ajustes constantes nessa autorrepresentação. A facilidade para se auto-observar e analisar a própria performance on-line poderia levar à construção de perfis que buscam preencher determinadas expectativas sociais mais do que representar as vivências do sujeito. Assim, no caso de perfis criados especialmente para destacar qualidades profissionais, o self tenderia a moldar essa representação a partir da experiência colateral do que é considerado um bom profissional segundo as atuais convenções com o objetivo de encaixar-se a um padrão aceito socialmente, o que pode levá-lo a "[...] modificar-se de forma que poderia impor algumas regras externas e alienígenas sobre o processo de construção da própria identidade.” (FLORIDI, 2014, p. 74). ${ }^{54} \mathrm{Ou}$ seja, à medida em que vivemos em ambientes digitais e confundimos uma representação do self - ou seja, uma identidade - com o próprio self, a subjetividade tenderia a ficar mais limitada e até distorcida.

\footnotetext{
53 "a proxy culture may become an ersatz culture, in which proxies become mere surrogates that not only hide their original references (the 'real' coffee) but make it hard or even impossible to reach it because they fully replace it without any residual link to na alternative reality. Aworld in which there is no chicory coffee is not a better world, but a world in which there is only chicory coffee is a worse, shallower world." (FLORIDI, 2015, p. 490)

54 “" [...] to modify themselves in a way that could impose some external and alien rules on the process of construction of One's own identity" (FLORIDI, 2014, p. 74)
} 
A parametrização da subjetividade permitiria o rastreamento e a classificação dos sujeitos a partir de dados, ou seja, sua transformação em mercadoria comercializável, como asseveram Couldry e Mejias (2019):

\begin{abstract}
As plataformas digitais são os meios tecnológicos que produzem um novo tipo de "social" para o capital: ou seja, o social de uma forma que pode ser continuamente rastreado, capturado, classificado e contado como valor "dados". As plataformas são um meio essencial pelo qual o domínio geral da vida cotidiana, grande parte dela até agora fora do escopo formal das relações econômicas, pode ser capturado dentro da rede de comercialização. (COULDRY, MEJIAS, 2019, p. 341). ${ }^{55}$
\end{abstract}

O uso de ferramentas tecnológicas para a produção do social para o mercado pode levar à criação de representações da subjetividade que funcionam como bloqueios para o self, uma vez que buscam engessá-lo a categorias e avaliações calcadas em dados do passado, ignorando, assim, que o selfé um processo.

Uma vez que as representações da subjetividade são mediadas por códigos e algoritmos, fica claro que uma pessoa não pode controlar completamente uma autorrepresentação construída dentro do ambiente digital, bem como os possíveis significados que serão gerados a partir dela. Entretanto, os códigos, os bancos de dados e os algoritmos tampouco podem determinar sozinhos as representações da subjetividade, pois o ambiente digital é um espaço dinâmico e de certo modo imprevisível, formado por diversos signos e atores, afetado pela cultura e por distintos interesses. Aqui, cabe destacar o caráter de rede do ambiente digital, na medida em que ele se constitui como uma estrutura que possibilita fluxos comunicacionais e conecta diferentes atores.

Acerca do conceito de rede, Musso (2013) propõe que "a rede é uma estrutura de interconexão instável, composta de elementos em interação, e cuja variabilidade obedece a alguma regra de funcionamento" (MUSSO in PARENTE, 2013, p. 31). Com o propósito de fazer a defesa de uma filosofia da rede, Musso (Ibid., p. 34) discorre sobre as noções de rede e esclarece o caráter ambivalente que o conceito adquiriu ao longo do tempo, uma vez que a rede pode permitir a circulação e a liberdade ou a vigilância e o controle. Como matriz técnica, Musso destaca que a rede se apresenta como uma forma de organização do espaço e do tempo, na medida em que "adiciona ao espaço-tempo físico um espaço

\footnotetext{
55 "Digital platforms are the technological means that produce a new type of "social" for capital: that is, the social in a form that can be continuously tracked, captured, sorted, and counted for value as "data." Platforms are a key means whereby the general domain of everyday life, much of it until now outside the formal scope of economic relations, can be caught within the net of marketization." (COULDRY, MEJIAS, 2019, p. 341)
} 
ampliado e um tempo reduzido" (MUSSO in PARENTE, 2013, p. 33). Nessa perspectiva, ela pode acelerar o tempo e encurtar distâncias, aproximando extremos e colocando em contato, de modo simultâneo, elementos de tempos e espaços distintos.

Independentemente da polissemia da noção de rede, a transitoriedade, o vínculo e o movimento são características inerentes ao conceito. Por conseguinte, "a rede é o veículo que nos transmuda em 'passantes', sempre mergulhados nos fluxos (de informações, de imagens, de sons, de dados...)". (MUSSO in PARENTE, 2013, p. 37). De fato, pensar nas narrativas da subjetividade no ambiente digital requer disposição para compreender o funcionamento das redes que o compõe enquanto estruturas em constante movimento.

\subsection{Impactos do sistema econômico nas autorrepresentações}

Dentro da lógica do atual sistema produtivo, as autorrepresentações digitais dos sujeitos são incentivadas enquanto expressões artísticas e como uma suposta maneira de revelar a própria singularidade. No chamado "capitalismo artista", termo definido por Lipovetsky e Serroy (2015), a estética e a arte são usadas para maximizar o consumo e o lucro. Esse novo estágio do sistema econômico seria pautado no imaginário, no imaterial, no sonho, no estímulo à expressão individual e na valorização de temas como realização pessoal, qualidade de vida e entretenimento.

O capitalismo artista é a formação que liga o econômico à sensibilidade e ao imaginário; ele se baseia na interconexão do cálculo e do intuitivo, do racional e do emocional, do financeiro e do artístico. No seu reinado, a busca racional do lucro se apoia na exploração comercial das emoções através de produções de dimensões estéticas, sensíveis, distrativas. (LIPOVETZKY; SERROY, 2015, p. 43-44).

Conformem pontuam os referidos autores, o sistema econômico busca incluir outras esferas da vida em seu funcionamento, recorrendo, para isso, à sensibilidade e às emoções. Se antes as relações de trabalho e consumo eram o alvo principal do capitalismo, hoje diversos aspectos da vida pessoal e íntima podem se transformar em mercadoria, até a própria subjetividade. No entanto, nesse modelo já não importa que os signos gerados tenham relação com a experiência vivenciada pelos sujeitos representados, mas apenas cumpram as expectativas dessa sociedade denominada pelos autores de "transestética": 
O avatar do Second Life se torna como que um outro eu, que impregnamos de nossos sonhos, nossos fantasmas, nossos desejos e que os realiza virtualmente, fazendo experimentar as sensações e os sentimentos que teríamos tido se os realizássemos na verdadeira vida: uma satisfação por procuração, uma transferência de realidade do seu eu próprio para um outro virtual (LIPOVETSKY; SERROY, 2015, p. 409).

A sobrevalorização do virtual ante a experiência corpórea aponta para um sistema em que as autorrepresentações digitais ganham um papel cada vez mais central dentro da lógica econômica. Do ponto de vista das motivações corporativas, as autorrepresentações são estimuladas por apelos que relacionam sucesso à exposição do eu, enquanto omite-se o fato de que a autoexposição dos usuários gera lucros para as empresas detentoras das plataformas em que as informações pessoais são compartilhadas. Esse tipo de discurso é patrocinado por redes sociais e companhias beneficiadas pela lógica da exposição. Para Marc Zukerberg, dono do Facebook e do Instagram, quem tem mais de uma identidade é desonesto:

Você tem uma identidade [...] Os dias em que você tem uma imagem diferente para seus amigos ou colegas de trabalho e para as outras pessoas que você conhece provavelmente estão chegando ao fim muito rápido. [...] Ter duas identidades para si mesmo é um exemplo de falta de integridade. (ZUCKERBERG in KIRKPATRICK, 2010, p. 199). ${ }^{56}$

Ora, se no início da web as pessoas utilizavam pseudônimos e interagiam em chats de modo anônimo, hoje a prática parece condenada pelas companhias, que incentivam a exposição e a uniformização das autorrepresentações. Mais do que isso, ao afirmar que cada pessoa deveria ter apenas uma identidade, Zuckerberg sugere que o self poderia ser substituído por uma autorrepresentação, como se toda a complexidade do sujeito pudesse ser reduzida a padrões e enquadrada às lógicas de suas plataformas.

Para orientar autorrepresentações alinhadas aos propósitos corporativos, empresas como o Facebook estimulam seus usuários a seguir as boas práticas da rede. No trecho abaixo, extraído do site do Instagram, a rede social sugere formas de construir uma "presença online" e atrair audiência:

\footnotetext{
56 "You have one identity [...] The days of you having a different image for your work friends or coworkers and for the other people you know are probably coming to an end pretty quickly. [...] Having two identities for yourself is an example of a lack of integrity." (ZUCKERBERG in KIRKPATRICK, 2010, p. 199).
} 
Amplifique sua voz: publicar em várias superfícies aumenta sua probabilidade de ser descoberto por novos públicos. Compartilhe seus destaques e momentos favoritos no Feed. Dê uma amostra de sua vida cotidiana com o Stories. Interaja com os fãs em tempo real, ao vivo. Vá mais fundo com seu público compartilhando vídeos mais longos no IGTV. (INSTAGRAM, 2019b).

O argumento é que a exposição da subjetividade seria uma forma de obter vantagens como alcançar novas audiências e visibilidade. Observamos que o Instagram sugere que seus usuários se esforcem para produzir conteúdos e expor sua vida íntima a partir de distintos recursos da rede, em diferentes formatos e de modo contínuo. Em outras palavras, tudo deve ser mostrado e compilado em uma autorrepresentação homogênea, plana e disponível. Busca-se um sujeito transparente, sem nada a esconder.

Como destaca Han (2018, p. 10), essa ideia de transparência remete à operacionalização das ações, o que permitiria que elas sejam calculadas, controladas e submetidas à aceleração. Nesse caso, revelar mais sobre a própria subjetividade implica em fornecer as informações pessoais necessárias para que os sistemas sejam continuamente aprimorados, trazendo vantagens aos seus controladores. Nesse sentido, haveria uma coação dos sujeitos para que se exponham cada vez mais e se tornem, eles mesmos, peças do sistema, em um movimento em que "tudo deve tornar-se visível; o imperativo da transparência coloca em suspeita tudo o que não se submete à visibilidade." (HAN, 2018, p. 35).

A chamada "sociedade da transparência", nos termos de Han (2018), realiza-se a partir da uniformização e da aceleração de seus processos guiadas por um imperativo econômico. Isso implica eliminar elementos de espontaneidade, singularidade e acaso em prol de uma sociedade dominada pela positividade, uma vez que "a negatividade da alteridade e do que é alheio ou a resistência do outro atrapalha e retarda a comunicação rasa do igual” (HAN, 2018, p. 11, itálico do autor). Nesse sentido, as tecnologias da informação e da comunicação e o modo de funcionamento das plataformas parecem contribuir para a concretização dessa sociedade positiva:

O veredicto da sociedade positiva é este: 'me agrada'. É significativo que o Facebook se negue coerentemente a introduzir um emotion de dislike bbotton. A sociedade positiva evita todo e qualquer tipo de negatividade, pois esta paralisa a comunicação. Seu valor é medido apenas pela quantidade e velocidade da troca de informações, sendo que a massa de comunicação também eleva seu valor econômico e veredictos negativos a prejudicam. Com like surge uma comunicação 
conectiva muito mais rápida do que com o dislike. (HAN, 2018, p. 24, itálico do autor).

Como avalia o referido autor, ao lado da positividade e da necessidade de exposição, a aceleração e o volume cada vez maior de informações conduzem ao fim do questionamento e da reflexão. Com a eliminação da complexidade, tudo se tornaria item de exposição e consumo efêmero, até o próprio sujeito: "também a face é um rosto que se tornou transparente, que anela pela otimização do valor expositivo. A coação por exposição nos rouba, em última instância, nossa própria face; já não é possível ser sua própria face" (HAN, 2018, p. 34-35, itálico do autor). É significativo observar, nessa perspectiva, a importância que os autorretratos, denominados selfies, assumiram nos últimos anos em redes sociais como o Instagram. ${ }^{57}$

Enquanto a exposição torna-se prerrogativa para a existência na sociedade da transparência e as imagens rasas se multiplicam, a contemplação estética cede lugar ao excesso de reações sem reflexão: "hoje, a comunicação visual se realiza como contágio, ab-reação ou reflexo" (HAN, 2018, p. 35). A aceleração do tempo e a multiplicação de imagens contribuem para que a comunicação seja simplificada e resumida à contabilização de likes e reações dos usuários. Aqui, podemos afirmar que essa lógica fundada pelo sistema econômico traz reflexos para a forma como as autorrepresentações são construídas, uma vez que, para se enquadrar nessa dinâmica, os sujeitos que se autorrepresentam o farão buscando modos de provocar reações e ganhar curtidas e comentários, mantendo, assim, o ritmo exigido para que seus perfis se tornem visíveis e para que gerem interpretantes alinhados a seus propósitos. Por esse ângulo, em vez de um processo complexo e espontâneo, a autorrepresentação alinha-se a padrões digitais e imperativos mercadológicos.

A partir das categorias fenomenológicas de Peirce, a "comunicação realizada como ab-reação" apontada por Han (2018) sugere a prevalência de aspectos de primeiridade e secundidade nas trocas comunicacionais, uma vez que elas passam a ser estimuladas principalmente por reações. Nesse sentido, embora a autorrepresentação seja construída dentro de um espaço simbólico, os processos interativos dos usuários, que

\footnotetext{
${ }^{57}$ Selfie foi eleita a palavra do ano em 2013 pelo Dicionário Oxford (KILLINGSWORTH, 2013). A definição de selfie é "uma fotografia que alguém tirou de si mesmo, especialmente uma tirada com um smartphone ou webcam e compartilhada através de mídia social.” (SELFIE, 2020, tradução nossa). Disponível em: $<$ https://www.oed.com/view/Entry/390063?redirectedFrom=selfie $>$. Acesso em 20 jul 2020 .
} 
ocorrem a partir dos conteúdos que emergem nas telas por meio de interfaces, tenderiam a ser pautados menos pela racionalidade e mais por impulsos e pelo entorpecimento provocado pelo ritmo frenético de sobreposição de informações.

De modo semelhante, Sodré (2002) indica que a apropriação e a transposição das experiências e da vida social ao ambiente digital, em um movimento coordenado pelo sistema econômico, operam uma profunda transformação nas formas de comunicação e sociabilidade, que passam a se realizar principalmente a partir da circulação voraz de imagens capazes de mobilizar os sentidos e as subjetividades em prol dos desígnios do capital. Isso ocorreria porque, à medida em que o sistema econômico reorganiza o mundo com o apoio das tecnologias, a dimensão simbólica dos vínculos comunitários e do estabelecimento do "comum" na sociedade perde espaço para um novo tipo de vínculo, orientado por objetivos mercadológicos e baseado na objetificação da vida (SODRÉ, 2002, p. 96).

À essa nova organização da vida no ambiente digital, capaz de transformar o espaço-tempo e criar novas realidades, Sodré (2002, p. 99) dá o nome de "bios midiático" ou "bios virtual", "uma espécie de comunidade afetiva de caráter técnico e mercadológico, onde impulsos digitais e imagens se convertem em prática social.” $\mathrm{O}$ autor pontua que a atual fase do sistema econômico leva os sujeitos a uma imersão no bios virtual, que passa a se apresentar como uma nova realidade, uma "vida vicária", regida por imagens sem referentes, baseadas em modelos hegemônicos do capital:

É verdade que os modelos geradores de imagens são logicamente inteligíveis. Na prática, porém, trata-se de um real semiurgicamente constituído em toda a sua extensão, uma verdadeira cultura das sensações e emoções, da qual se faz uma experiência mais afetiva do que lógico-argumentativa. Daí a prevalência dos estereótipos, que são emoções coletivas esteticamente condensadas, nos territórios imateriais do bios midiático. (SODRÉ, 2002, p. 102).

Esse processo conduziria a um novo regime de visibilidade, "em que a visibilidade incorpora facetas sonoras e táteis, incrementando a potência interativa do sistema comunicacional e, por consequência, dos sujeitos sociais que 'imergem' sensorialmente nos fluxos midiáticos” (SODRÉ, 2002, p. 103). Ou seja, a visualidade relacionada a processos cognitivos como os que envolvem a leitura, mais identificados com a categoria fenomenológica peirceana da terceiridade, dá lugar às qualidades de sentimentos e às reações aos impactos provocados pelo espetáculo das imagens. Em vez de orientada por 
propósitos como os de restabelecer o "comum", a comunicação passa a ser orientada às necessidades particulares de grandes companhias e de lógicas econômicas alheias ao crescimento e desenvolvimento do self.

Sem nos aprofundarmos nas inúmeras e relevantes questões levantadas por Sodré (2002), interessa-nos destacar, por fim, que o autor sugere, com base nas definições de signo peirceanas, que a imersão no bios midiático leva a uma prevalência de um regime indicial nas trocas nesse espaço. Isso não significa que o simbólico e o icônico não estejam presentes, mas a profusão de imagens, combinada com a alta velocidade dos fluxos de informação, a fragmentação e a não-linearidade dos discursos, favoreceriam a predominância dos índices nas trocas entre os sujeitos:

O índice configura-se como o signo mais adequado a um novo tipo de relação social carente de dimensões de profundidade semântica ou de valores éticos ordenados, em que predomina, no lugar da clássica 'interioridade' psíquica ou do sujeito definido por um ponto de vista estratégico, a pura contiguidade relacional das redes midiáticas ou cibernéticas. Ele é de fato o principal operador das relações entre a lógica do discurso e as modulações da sensibilidade na esfera do audiovisual. (SODRÉ, 2002, p. 109).

Ora, conforme pontua Peirce (2017), os índices são signos que representam um objeto por uma conexão real com ele. Os índices também são indícios, atraem a atenção e "alguns índices são instruções mais ou menos detalhadas daquilo que o ouvinte precisa fazer a fim de pôr-se em conexão experiencial direta ou de outro tipo, com a coisa significada" (PEIRCE, 2017, p. 69). Além disso, os índices correspondem à categoria fenomenológica da secundidade, ou seja, a prevalência da indicialidade sugere que processos típicos de terceiridade, como a racionalização e a interpretação, são preteridos nessas trocas em prol da mera ação e reação. Nesse sentido, ao analisarmos as autorrepresentações, consideraremos em que medida os índices são mobilizados e contribuem para a atualização dos signos presentes na autorrepresentação.

\subsection{O self e os processos participativos no digital}

A compreensão dos processos de autorrepresentação no ambiente digital também deve partir do pressuposto do caráter dialógico do self e de sua definição como "agente comunicativo" (COLAPIETRO, 2014). Assim, admitimos que a construção de autorrepresentações no ambiente digital depende do papel ativo desempenhado pelo self, 
bem como do papel de outros sujeitos que interagem nesse espaço. Para discutirmos os processos participativos do ambiente digital, é importante considerar o conceito de cibercultura. Por isso, começamos com as ponderações do filósofo francês Pierre Lévy e sua abordagem sóciotécnica dos fenômenos relacionados ao desenvolvimento das tecnologias digitais de informação e comunicação. De acordo com Lévy (1999), o avanço e a popularização dessas tecnologias, especialmente da internet, contribuíram para a emergência de um novo espaço global de trocas comunicacionais, o "ciberespaço", cujo surgimento está relacionado ao nascimento da chamada "cibercultura".

Conforme descreve o autor supracitado, o ciberespaço não se caracteriza apenas por seu caráter técnico, uma vez que engloba, além da infraestrutura material que possibilita a interconexão entre computadores, uma grande quantidade de informações e também os seres humanos que participam desse espaço. Já a cibercultura “especifica aqui o conjunto de técnicas (materiais e intelectuais), de práticas, de atitudes, de modos de pensamento e de valores que se desenvolvem juntamente com o crescimento do ciberespaço." (LÉVY, 1999, p. 16). Em outras palavras, o ciberespaço e a cibercultura abarcam um conjunto de práticas culturais que trouxe grandes mudanças nas formas de sociabilidade e comunicação contemporâneas.

No contexto da cibercultura, a conexão global e instantânea contribuiu para o surgimento de interações mais descentralizadas em relação às formas tradicionais de comunicação e, de certo modo, aleatórias. Ou seja, já não há divisão rígida entre os polos emissor e receptor. Sobre a cibercultura, Lévy (1999) assinala que

trata-se de um universo indeterminado e que tende a manter sua indeterminação, pois cada novo nó da rede de redes em expansão constante pode tornar-se produtor ou emissor de novas informações, imprevisíveis, e reorganizar uma parte da conectividade global por sua própria conta. (LÉVY, 1999, p. 111).

Lévy caracteriza a cibercultura como um universo sem centro ou ordem prédeterminada, cujo movimento acompanha o crescimento do ciberespaço. Segundo ele, o ciberespaço cresce orientado pela interconexão, pela criação de comunidades virtuais e pela formação da chamada "inteligência coletiva", uma coleção de saberes acumulados e compartilhados que estaria à disposição da humanidade. Apesar da perspectiva otimista, Lévy admite que a inteligência coletiva pode assumir a função de remédio ou veneno: no primeiro caso, devido ao caráter participativo, ela ajudaria a minimizar os efeitos do ritmo excludente das mudanças técnicas; já no segundo, a aceleração das mutações técnicas 
promovida por essa inteligência significaria um veneno para aqueles que estão excluídos dela e não se apropriam de suas transformações (LÉVY, 1999, p. 28-29).

Entendemos que essa abordagem esperançosa da cibercultura deve ser balanceada com uma visão crítica sobre os controles exercidos por governos e companhias públicas e privadas na circulação de informações e nas dinâmicas do ambiente digital. Entretanto, é importante reconhecer que os processos participativos são inerentes à cibercultura. Por essa ótica, Lévy (1999) alerta que o ciberespaço não deve ser compreendido como infraestrutura técnica, mas como uma forma de usar tais infraestruturas de modo distribuído e inerentemente social: "o nervo do ciberespaço não é o consumo de informações ou de serviços interativos, mas a participação em um processo social de inteligência coletiva." (LEVY, 1999, p. 197).

Jenkins, Green e Ford (2014) partem da transição do universo da comunicação para discorrer sobre o desenvolvimento de um modelo mais participativo de cultura, em que o antigo paradigma de criação e distribuição de conteúdos controlados por grandes empresas perde força e passa a dividir espaço com um público que deixou há muito tempo de ser apenas receptor passivo de mensagens. Em vez de meros receptores de informações, os sujeitos "[...] estão moldando, compartilhando, reconfigurando e remixando conteúdos de mídia de maneiras que não poderiam ter sido imaginadas antes" (JENKINS; GREEN; FORD, 2014, p. 24). Os autores se afastam de um viés meramente tecnicista ao pontuar que essa cultura mais participativa é fruto de lógicas sociais e culturais, embora as facilidades técnicas trazidas pelo digital possam servir como catalisadoras desse processo.

Entretanto, observam os autores, os processos participativos devem ser compreendidos em suas limitações e nuances, uma vez que até pessoas com habilidades para usar as tecnologias de acordo com seus próprios objetivos podem ter sua capacidade de participação comprometida "por questões ligadas a quem detém a propriedade das plataformas através das quais ocorre a comunicação e como as suas agendas definem a forma como tais ferramentas podem ser empregadas." (JENKINS; FORD; GREEN; 2014, p. 241). Apesar das diferentes forças que podem impactar a participação na cultura digital, Jenkins, Green e Ford (2014) destacam o caráter "propagável” intrínseco a esse modelo, que pode ser identificado pelo potencial técnico e cultural do público de se apropriar e compartilhar conteúdos por distintos motivos, reconfigurando-os e dando a eles novos sentidos (JENKINS; FORD; GREEN; 2014, p. 26; 30; 241; 354). Nessa cultura regida 
pela propagabilidade não há limites fixos, uma vez que não se pode prever os modos de apropriação e circulação dos conteúdos, tampouco controlar todas as dinâmicas:

E, nesse tipo de ambiente, qualquer parte pode bloquear ou retardar a propagação de textos; se os criadores fazem bloqueios legais ou técnicos, se os proprietários de plataformas (terceiros) optam por restringir as formas como o material pode circular, ou se os públicos se recusam a circular o conteúdo que deixa de atender aos seus próprios interesses. (JENKINS; FORD; GREEN; 2014, p. 355).

Os sujeitos que participam das dinâmicas dos ambientes digitais são denominados "web atores" por Pisani e Piotet (2010), pois:

Em lugar de simplesmente receber, nós produzimos, publicamos, agimos. Usuários ativos, somos consumidores/criadores, leitores/escritores, ouvintes/gravadores, espectadores/produtores. Temos até o poder de organizar todos esses dados (informações, conhecimentos, criações), atribuindo-lhes etiquetas de nossa criação, tags. Geramos um conteúdo, que organizamos e modificamos a cada instante. (PISANI, PIOTET, 2010, p. 120).

Os autores defendem que a chamada web 2.0 é um ambiente caracterizado sobretudo pela participação, embora ela não se dê de modo igualitário e satisfatório entre todos os participantes. A condição de "web atores" é possibilitada pelo Instagram, uma vez que a rede oferece opções para que qualquer usuário atue concomitantemente como produtor e consumidor de conteúdos, interferindo nos fluxos semióticos de várias formas: além de publicar fotos, textos e vídeos, é possível fazer comentários, curtir conteúdos, compartilhar, enviar mensagens privadas, seguir outros perfis, seguir hashtags, etc. Esses processos participativos dariam origem a novas dimensões e propriedades imprevisíveis. Aos resultados dessa dinâmica participativa Pisani e Piotet (2010) dão o nome de "alquimia das multidões":

Exemplo da dinâmica relacional, a alquimia das multidões é o processo incerto graças ao qual a participação maciça de humanos e de programas conectados entre si pode produzir o surgimento de novas propriedades. Ela implica uma mistura sempre variável de acumulação, de compilação, de relacionamento de dados e participantes diferentes. (PISANI, PIOTET, 2010, p. 175).

O acúmulo de dados, a diversidade de fontes e participantes, a possibilidade de mesclar e sintetizar informações de diferentes origens e o relacionamento entre dados, 
máquinas e participantes, juntos, possibilitariam, segundo os autores, o aparecimento de novos atributos que não podem ser compreendidos apenas como uma soma das partes. Pisani e Piotet (2010) esclarecem que a escolha do termo "alquimia" chama a atenção para o fato de que nem sempre essa dinâmica gera resultados esperados ou positivos, enquanto o termo "multidões" destaca a heterogeneidade e a diversidade dos "web atores".

Ao discorrer sobre a comunicação mediada pelo computador e por sites de redes sociais, Recuero (2012) destaca que o distanciamento físico entre os participantes nesses ambientes leva a uma apropriação da linguagem e dos contextos como elementos de construção de identidades, que passam a oferecer visibilidade aos participantes das trocas comunicacionais. Esse processo é facilitado pela mediação tecnológica, na medida em que ela possibilita o armazenamento, a replicação e a transformação das informações trocadas no ambiente digital, embora essa permanência não esteja dada. Assim, textos, imagens, vídeos, áudios e outras interações podem contribuir para a construção da presença do sujeito no digital, ou seja, esses elementos passam a se constituir como representações da subjetividade. Nesse sentido, Recuero (2012) afirma que perfis em redes sociais são conversações:

Podemos dizer que eles (perfis) se constituem em conversações em "rede" na medida em que são construídos e adaptados através das trocas construídas com outros atores, dos valores que são negociados e dos sentidos que se deseja construir. Esses perfis, portanto, constituem enunciados que focam a questão básica da identidade dos atores. Propostos por estes, os enunciados recebem legitimação ou não pela rede e são adaptados, através dessas trocas simbólicas (comentários, interações e, mesmo, percepções do autor do perfil), de forma a delimitar e aperfeiçoar a ideia que se deseja construir pelo enunciado. (RECUERO, 2012, p. 142-143).

Ou seja, a autorrepresentação não se dá apenas por meio de elementos escolhidos para esse fim, mas se expande para os comentários, compartilhamentos e outras ações executadas nesse ambiente, que passam a fazer parte da identidade do sujeito no digital. Nessa perspectiva, entendemos que as autorrepresentações dependem das interações e negociações feitas pelos sujeitos interconectados. Uma autorrepresentação não é um signo estático, mas um conjunto dinâmico de signos em interação constante. Conforme argumenta Recuero (2012), os enunciados propostos por um sujeito em seu perfil passam por processos de validação e reelaboração por outros membros da rede, podendo ser 
reajustados novamente pelo sujeito em prol de uma representação mais condizente com seus propósitos e assim sucessivamente.

Recuero (2012, p. 134) destaca que as conversações que ocorrem em redes sociais digitais contribuem para a construção coletiva de valores que podem ser usados de modo individual por cada membro que participa da rede. Em consonância com Pierre Bordieu e outros autores, Recuero usa o termo "capital social" para se referir a esses recursos relacionados ao pertencimento a uma rede social. Nesse sentido, considerando nosso objeto de pesquisa, podemos afirmar que a criação de um perfil profissional no Instagram facilitaria a apropriação de valores que contribuiriam para a legitimação de coaches de carreira, uma vez que por meio desses perfis eles se tornam aptos a participar das conversações e têm a possibilidade de ampliar seu capital social. As interações nesses ambientes também estão relacionadas à visibilidade, à reputação e à popularidade. Assim,

Quanto mais citado é alguém, quanto mais referências a sua participação na conversação, maior visibilidade. Quanto mais indivíduos têm acesso ao que diz e concordam com esse ator, mais elementos de reputação este soma, além de aumentar sua popularidade e visibilidade. (RECUPERO, 2012, p. 137).

Nesse sentido, a autorrepresentação é validada na medida em que recebe aprovações, citações e referências. Do ponto de vista da Semiótica, a semiose só é efetivada quando o signo é interpretado. Nesse sentido, entendemos que, ao construir uma autorrepresentação por meio de um perfil, o criador busca estratégias para que os signos presentes no perfil sejam atualizados, ou seja, gerem interpretantes ou encontrem intérpretes capazes de interpretar suas potencialidades. O processo de se autorrepresentar está intimamente conectado à capacidade de negociar capital social, bem como à habilidade de compreender as dinâmicas do ambiente digital e de se apropriar dos recursos tecnológicos disponíveis para ajustar constantemente a autorrepresentação, levando em conta os próprios objetivos, as exigências das plataformas e as tendências e anseios de outros usuários.

Ainda sobre as conversações mediadas pelo computador, Recuero (2012, p. 51) salienta que elas podem ocorrer de modo síncrono, quando há respostas imediatas, e de forma assíncrona, quando a conversação se prolonga no tempo, uma vez que as trocas comunicacionais adquirem permanência e podem ser recuperadas e atualizadas posteriormente. Assim, as conversações podem ocorrer em um período maior e sem a copresença física dos participantes, que acaba sendo substituída por uma presença virtual, 
pois "o ambiente registra as mensagens e as representações, permitindo que indivíduos que visitem o ambiente em momentos diferentes possam dar continuidade à conversação". (RECUERO, 2012, p. 54). Por conseguinte, a perenidade dessas trocas e as comunicações assíncronas podem trazer impactos na construção das autorrepresentações, uma vez que, ao serem recuperados em distintos momentos, esses registros podem ativar novas conversações e gerar novos sentidos, reconfigurando continuamente as representações da subjetividade.

As dinâmicas comunicacionais no ambiente digital apontam para a necessidade de observá-las em movimento e em todas as suas dimensões, a fim de que se alcance uma compreensão mais aprofundada do fenômeno que se pretende estudar. Isso significa que não se pode considerar apenas os aspectos técnicos do espaço virtual, tampouco avaliar apenas as ações dos sujeitos envolvidos ou os interesses de empresas e governos. Por esse ângulo, Primo (in PRIMO, 2016, p. 29) alerta para o risco da adoção de um discurso dicotômico, que tente classificar as mídias relacionadas às interações mediadas por computador como boas ou más segundo o uso dado a elas, ou de um relativismo exacerbado que desemboque em determinismo. O autor aponta, assim, que as associações que se dão no decorrer do processo comunicativo no ambiente digital não podem ser controladas por um ator de modo definitivo, uma vez que são "criadas por todos os envolvidos enquanto ocorrem. As tensões que daí emergem demandam negociações que reconfigurarão as ações a todo momento." (PRIMO in PRIMO, 2016, p. 30).

Isto posto, o estudo das autorrepresentações no ambiente digital requer encarar as múltiplas possibilidades que esse espaço apresenta, considerando as tensões que emergem das interações. Sobre esse aspecto, concordamos que "pensar a produção e a recepção como polos que se negam prejudica a compreensão do processo midiático enquanto complexidade não redutível ou particionável.” (PRIMO in PRIMO, 2016, p. 30).

\subsection{Autorrepresentações no Instagram}

Nesta seção, apresentamos uma breve discussão sobre o funcionamento e as características do Instagram, pois, como argumentamos ao longo deste capítulo, entendemos que a investigação das autorrepresentações não pode ser dissociada da plataforma na qual elas se inserem. Iniciamos a seção com o histórico da rede e em seguida detalhamos aspectos da interface diretamente envolvidos nas autorrepresentações. Aqui, buscamos relacionar as funcionalidades do Instagram à 
Semiótica e às discussões e conceitos apresentados neste capítulo, com o objetivo de reunir subsídios para a compreensão das operações semióticas implicadas nos processos de autorrepresentação.

O Instagram foi criado pelo norte-americano Kevin Systrom e pelo brasileiro Mike Krieger e lançado em 2010 como aplicativo para smartphones e tablets disponível apenas para o sistema iOS, compatível com produtos da Apple, como o iPhone. A princípio, o Instagram tinha como proposta a edição e o compartilhamento de fotos, sempre em formato quadrado. Por meio de ferramentas de edição chamadas "filtros", o app possibilitava a personalização de imagens, deixando-as, por exemplo, com o aspecto de fotos feitas por câmeras fotográficas antigas. Ou seja, o destaque eram as fotografias, que podiam ser publicadas na plataforma e em redes sociais como o Facebook e o Twitter.

Em estudo qualitativo combinado com a análise computacional de 16 milhões de fotos publicadas no Instagram entre 2012 e 2016 em dezesseis cidades em todo o mundo, Monovich (2016) pontua que o Instagram foi fundamental para a criação e o desenvolvimento de uma nova forma de cultura visual, que mescla fotografia e design e tem como característica a escolha de assuntos (preferências alimentares, moda, objetos de design, texturas) e composições específicas associada aos recursos tecnológicos fornecidos pela rede. A essa combinação de conteúdo específicos e formato de mídia o autor propôs o termo Instagrammism.

O Instagram era diferente dos serviços de compartilhamento de fotos existentes porque vinha com filtros e outras ferramentas simples de edição de imagens disponíveis em seu aplicativo móvel. E isso democratizou a confecção de imagens bonitas. Gradualmente, o Instagram também foi adotado por milhões de pessoas jovens e sofisticadas ao redor do mundo para exibir suas fotografias, narrar suas ideias e experiências e se conectar. (MANOVICH, 2016, p. 4). ${ }^{58}$

Segundo Manovich (2016), a estética do Instagram tinha forte participação na formação das identidades dos usuários da rede (denominados instagrammers) que, a partir das escolhas feitas em suas postagens, alinhavam-se a determinados grupos e subculturas.

\footnotetext{
58 "Instagram was different from then existing photo-sharing services because it came with filters and other simple image editing tools available in its mobile app. And this democratized making good-looking images. Gradually, Instagram was also adopted by millions of young, sophisticated people around the world to display their photography, narrate their ideas and experiences, and connect to each other." (MANOVICH, 2016, p. 4).
} 
Nos últimos anos, o Instagram ampliou o número de ferramentas e suas possibilidades de uso, com a inclusão de postagem de vídeos, conteúdos efêmeros e transmissões ao vivo, e recursos comerciais. As mudanças também alcançaram a aparência da interface, como pode ser observado no perfil de Kevin Systrom, um dos cofundadores do Instagram, em dois momentos, 2012 (figura 1) e em 2020 (figura 2):

Figura 1 - Perfil de Kevin Systrom em 2012.

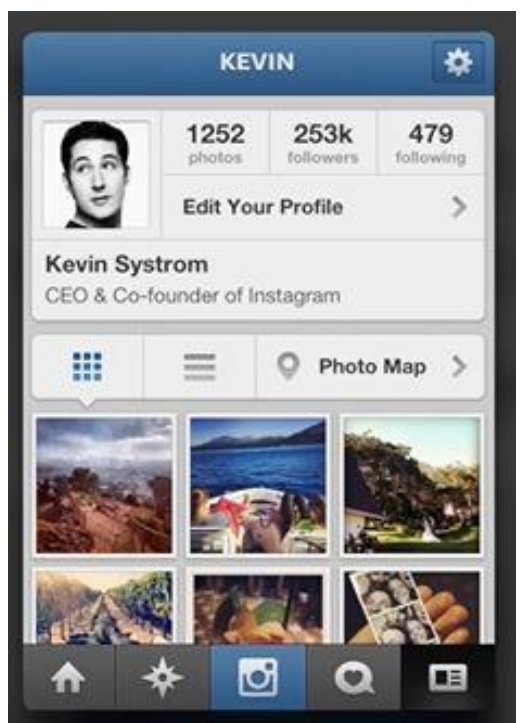

Fonte: Instagram. Disponível em: $<$ https://about.instagram.com/about-us $>$. Acesso em: 20 mai. 2019.

Figura 2 - Perfil de Kevin Systrom em 2020.

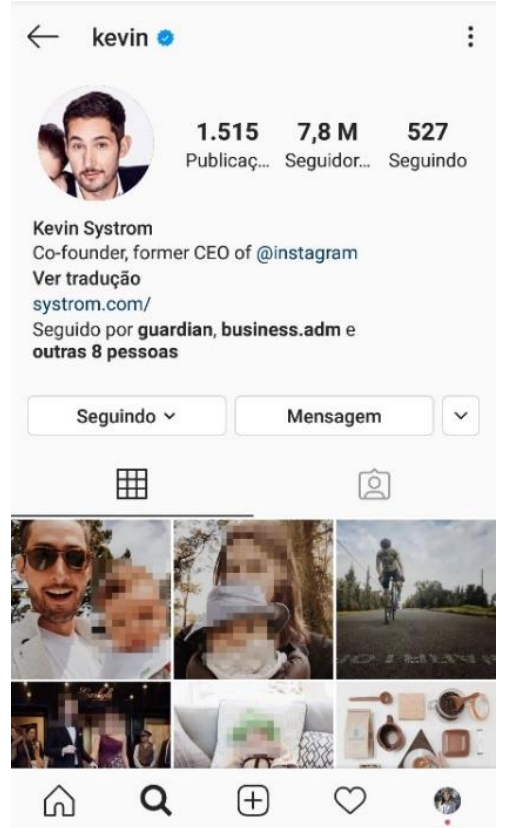

Fonte: Print screen do perfil da pesquisadora no Instagram. 
Grosso modo, podemos afirmar que a participação no Instagram se dá a partir da criação de um perfil, no qual o usuário pode incluir foto de perfil e informações pessoais e publicar imagens, entre outras ações que serão detalhadas a seguir. Como rede social digital, o Instagram permite que o usuário estabeleça conexões, tornando-se "seguidor" de outros perfis e ganhando "seguidores" que decidem se conectar ao seu perfil, além de acompanhar as atividades de outras contas, interagir, produzir e compartilhar conteúdo. Além do perfil, o feed é outro espaço importante na interface da rede. Ele reúne as principais atualizações das conexões do perfil (ou seja, dos perfis seguidos, entre pessoais e comerciais) e exibições de publicidade, com base em critérios definidos pelo Instagram com o uso de algoritmos.

Em abril de 2012, o Instagram ganhou uma versão para o sistema Android e foi comprado pelo Facebook, o que permitiu a expansão da base de usuários e a integração com serviços oferecidos pelo Facebook. ${ }^{59}$ Naquele ano, a rede, que contava com 80 milhões de usuários, já demonstrava interesse em oferecer agilidade no uso da interface, como sugere o anúncio de imprensa que informava sobre a possibilidade de buscar fotos por meio de hashtags ${ }^{60}$ e geolocalização: "Introduzimos uma maneira nova e exclusiva de navegar pelas suas fotos e pelas de outras pessoas em um mapa, o que significa que você não está mais restrito a navegar página por página.” (INSTAGRAM, 2012).

Ainda em 2012, a rede introduziu a chamada "rolagem infinita no feed" (infinite scrolling), que permitia que o usuário pudesse "ver rapidamente mais fotos durante a navegação pelo aplicativo" (INSTAGRAM, 2012). É interessante observar que esse tipo de organização das informações no feed estimula o usuário a percorrer os conteúdos infinitamente, sem encontrar um limite, o que o leva a permanecer mais tempo conectado,

\footnotetext{
${ }^{59}$ Disponível em: < https://instagram-press.com/ru/blog/2012/04/09/instagram-facebook/> e $<$ http://g1.globo.com/tecnologia/noticia/2012/04/facebook-anuncia-compra-do-instagram.html $>$. Acesso em: 10 jul. 2019.

${ }^{60}$ Hashtag refere-se a uma palavra ou frase com o símbolo '\#' na frente, usada em alguns sites, o que a transforma em hiperlink e permite que seja indexada em mecanismos de busca. No Instagram, as hashtags aparecem em destaque, na cor azul. Em inglês, o símbolo '\#' chama-se hash (ou octothorp, em contextos técnicos), de acordo com o Dicionário Oxford. Já a palavra tag significa etiqueta, estando relacionada aos processos de identificação de informações ou outros elementos. Assim, hashtag remete ao processo de etiquetamento e categorização de informações, que se tornou popular na rede social Twitter. A palavra hashtag foi adicionada oficialmente ao Oxford English Dictionary (OED) em 2014. Informações disponíveis em: < https://www.oed.com/view/Entry/389023\#eid301493073>, < https://www.oxfordlearnersdictionaries.com/definition/english/tag_1?q=tag $>$ e $<$ https://time.com/2870942/hashtag-oed-oxford-englishdictionary/\#: :text=The $\% 20$ word $\% 20$ hashtag\%20has,in $\% 20 \mathrm{a} \% 20 \mathrm{blog} \% 20$ post $\% 20$ Friday. $>$. Acesso em 20 mai 2020.
} 
deixando-se levar pelo enorme volume de conteúdos que emerge na interface ${ }^{61}$ Em 2018 , o Instagram passou a emitir um alerta no feed, após o usuário visualizar todos os posts disponíveis, com a mensagem "Isso é tudo - você viu todas as novas publicações dos últimos dois dias."

Em 2013, o Instagram ganhou uma versão para desktop e anunciou a possibilidade de veicular publicidade entre seus conteúdos, opção que chegou ao Brasil em 2015, quando as postagens pagas passaram a ser exibidas com o aviso "patrocinado". Houve ainda a introdução de vídeos no feed (a princípio de 15 segundos, depois de até 60 segundos), da troca de mensagens privadas por meio do Direct Message e de novos formatos para publicação de fotos (retrato e paisagem).

A partir de 2013, a rede também passou a oferecer a possibilidade de identificar pessoas e perfis nas publicações. Ou seja, a cada foto ou vídeo postado, o usuário pode indicar quem está presente na imagem, adicionando o referido perfil, que pode ser acessado por outros usuários por meio de um clique. Além disso, ao ter o próprio perfil marcado em uma publicação de terceiros, o usuário pode decidir se deseja manter ou não a marcação - caso seja aceita, a imagem passa a integrar a seção do perfil denominada "Fotos com você", que pode ser acessada por outros usuários.

Suas legendas e hashtags capturam o "o quê?" e seu mapa de fotos responde "onde?" mas até hoje nunca conseguimos responder ao "quem?". Hoje, temos o prazer de oferecer uma nova maneira de compartilhar e descobrir histórias no Instagram. Ao enviar uma foto para o Instagram, agora você pode adicionar pessoas tão facilmente quanto adiciona hashtags. (INSTAGRAM, 2013).

O recurso permite, assim, a conexão entre diferentes contas ou perfis, aumentando as possibilidades de trajetórias entre os conteúdos da rede e amplificando as possiblidades de semiose.

Uma das principais mudanças ocorreu em 2016, quando o Instagram anunciou que passaria a personalizar o feed de seus usuários. Até então, os conteúdos postados na rede apareciam no feed de acordo com a data e hora em que eram postados, do mais recente

\footnotetext{
${ }^{61}$ Aza Raskin, criador do chamado infinite scroll, afirmou em entrevista à BBC que o modelo é viciante e pode levar ao descontrole e à dependência no uso de redes sociais: "Se você não der tempo ao seu cérebro para acompanhar seus impulsos, você apenas continua rolando". Disponível em: <

https://www.bbc.com/news/technology-44640959>. Acesso em: 20 mai 2020.

${ }^{62}$ Disponível em: < https://www.techtudo.com.br/noticias/2018/07/instagram-avisa-voce-esta-atualizadopara-quem-ja-viu-todos-os-posts.ghtml>. Acesso em: 20 mai 2020.
} 
para o mais antigo, em ordem cronológica reversa. Além disso, cada usuário podia visualizar, por meio de seu feed, todas as publicações de suas conexões (perfís seguidos). Segundo a empresa, o objetivo da mudança foi dar prioridade às postagens supostamente mais relevantes:

\begin{abstract}
Para melhorar sua experiência, seu feed será em breve modificado para mostrar os momentos em que acreditamos que você se preocupa mais. A ordem de fotos e vídeos em seu feed será baseada na probabilidade de você estar interessado no conteúdo, no seu relacionamento com a pessoa que postou e a pontualidade da postagem. (INSTAGRAM, 2016a).
\end{abstract}

A introdução de algoritmos na organização do feed desagradou alguns usuários, que fizeram um abaixo-assinado na plataforma Change.org no qual argumentavam que perderiam o controle do que veem na rede social. A petição obteve mais de $341 \mathrm{mil}$ assinaturas, mas não convenceu o Instagram a voltar atrás em sua decisão. ${ }^{63}$ Como sugere Pariser (2012, p. 102), essa interferência no feed pode afetar a constituição dos sujeitos: "ao apresentar algumas possibilidades e bloquear outras, a bolha dos filtros influencia nossas decisões. E, assim, molda a pessoa na qual nos transformamos.”

A rede também lançou a ferramenta Stories (Histórias, em português), que possibilita o compartilhamento de conteúdos com duração de apenas 24 horas. De acordo com o Instagram, os Stories permitem que o usuário faça muitas postagens sem a preocupação de overposting (excesso de postagem), uma vez que o conteúdo some da rede após o período de um dia, sem ficar registrado no perfil ou no feed. Nesse sentido, os Stories estimulam a postagem de fotos do dia a dia, de situações do corriqueiras, sem muita racionalização: "você pode compartilhar o quanto quiser ao longo do dia - com a criatividade que quiser. Você pode dar vida à sua história de novas maneiras com as ferramentas de texto e desenho." (INSTAGRAM, 2016b). Hoje, os Stories podem ser salvos e dispostos como destaques no perfil, para que outros usuários possam acessá-los após 24 horas. Nesta opção, os usuários fazem uma seleção mais apurada do que foi publicado anteriormente, organizando e colocando tais conteúdos em lugar de destaque em seus perfis.

Outro passo para a mudança nas funções do Instagram foi a alternativa de transformar perfis comuns em perfis comerciais (ou profissionais), opção lançada em

\footnotetext{
${ }^{63}$ Disponível em: <https://www.change.org/p/keep-instagram-chronological>. Acesso em: 13 abr 2019.
} 
2016 e inicialmente disponível para empresas que tivessem perfil com pelo menos 100 seguidores e uma página de fãs no Facebook, solicitada durante o cadastro. ${ }^{64}$ Hoje, pessoas físicas também podem aderir ao perfil profissional, sem exigências prévias.

Desde 2017, a rede oferece a opção de seguir hashtags, o que, segundo a companhia, facilitaria a conexão dos usuários com assuntos de seu interesse por meio da visualização de publicações de outros perfis que tenham sido previamente indexadas com as hashtags escolhidas. Em 2018, a rede lançou a ferramenta IGTV, que permite a publicação de vídeos de até uma hora. Além de aparecer no feed ao ser publicado, o vídeo do IGTV também fica armazenado em uma área específica do perfil do usuário que o publicou. Ao longo desses anos, os Stories também ganharam novos recursos, como filtros de edição de imagem, etiquetas, hashtags, gifs, a possiblidade de adicionar música, etc.

Em apresentação no blog da empresa, o Instagram tem a seguinte máxima: "Nós aproximamos você das pessoas e coisas que ama". ${ }^{65}$ De acordo com a descrição do aplicativo do Instagram disponível na loja de aplicativos Google Play, a proposta é permitir que o usuário se conecte com amigos, compartilhe o que está fazendo, veja as atividades de outras pessoas em todo o mundo, descubra marcas e pequenas empresas, e compre produtos relacionados ao seu estilo pessoal, entre outras possibilidades. Há um apelo para que o usuário expresse o próprio eu, como se fosse possível transpor todas as experiências da vida à rede: "Explore nossa comunidade, um local onde você pode ser você mesmo(a) e compartilhar de tudo; da sua rotina a momentos importantes da sua vida." ${ }^{66}$ Nesse sentido, o discurso da rede está alinhado à lógica do "capitalismo artista", no qual a autoexpressão no ambiente digital se converte em forma de se autoafirmar no mundo:

O gosto de se expressar se democratizou sob o impulso da cultura individualista-hedonista-psicológica, que leva os indivíduos a realizar atividades mais ricas que permitam manifesta um Eu singular: maneira de se desenvolver, de se realizar, de ser quem se é. Há nisso uma necessidade de dizer e de se exprimir tanto maior por terem os grandes combates coletivos deixado de emprestar um sentido forte à existência. (LIPOVETSKY; SERROY, 2015, p. 410-411).

\footnotetext{
${ }^{64}$ Disponível em: < https://www.techtudo.com.br/noticias/noticia/2016/08/instagram-libera-conta-deempresa-no-brasil.html>. Acesso em: 20 abr 2019.

${ }^{65}$ Disponível em: $<$ https://about.instagram.com/about-us $>$. Acesso em: 10 abr 2020.

${ }^{66}$ Disponível em $:<$ https://play.google.com/store/apps/details?id=com.instagram.android\&hl=pt_BR $>$. Acesso em: 10 abr 2020.
} 
Entendemos que as mudanças implementadas pelo Instagram, associadas às apropriações feitas por usuários e por diferentes marcas e companhias públicas e privadas, ajudaram a reconfigurar o papel da rede, que deixou de ser um espaço prioritariamente dedicado ao estabelecimento de comunidades baseadas em uma determinada cultura visual para se tornar também uma plataforma que conjuga distintos aspectos da vida, entre gostos pessoais e interesses profissionais e empresariais, em um só lugar. ${ }^{67}$ Por conseguinte, os apelos comerciais e a abertura do Instagram para o estabelecimento de conexões mais explicitamente mercadológicas podem ter influência nas formas como os sujeitos se autorrepresentam na rede, especialmente em perfis profissionais, uma vez que tal representação é supostamente criada com o objetivo de obter benefícios diferentes do sentido de pertencimento a uma comunidade.

\subsubsection{Perfil}

Em nossa análise sobre as autorrepresentações, o perfil tem papel de destaque. Nesse sentido, detalhamos as principais características dos perfis e, em especial, de perfis profissionais. O perfil pessoal é formado pelos seguintes elementos: nome de usuário (até 30 caracteres com espaços), foto (opcional), nome (opcional, com até 30 caracteres com espaços), biografia de até 150 caracteres com espaço (opcional), site (opcional), destaques dos stories (opcional). Além disso, o perfil exibe o número de publicações feitas pelo usuário, o número de seguidores e número de perfis seguidos, como pode ser observado na figura $3 .{ }^{68}$

\footnotetext{
${ }^{67}$ Neste caso, usamos a palavra "plataforma" no sentido discutido por Dijck, Poell e Waal (2018), qual seja, uma arquitetura programável que organiza as atividades dos usuários e, mais do que isso, participa cada vez mais na estruturação da sociedade. Como destacam os referidos autores, "uma plataforma é alimentada por dados, automatizada e organizada através de algoritmos e interfaces, formalizados através de relações de propriedade conduzidas por modelos de negócios e regidos por contratos de usuário" (DIJCK; POELL; WAAL, 2018, p. 20, tradução nossa). Entretanto, entendemos que, para os objetivos traçados nesta dissertação, seria mais adequado fazer a discussão do Instagram considerando-o prioritariamente uma rede social, uma vez que nosso foco está em investigar as autorrepresentações, e não o papel das plataformas na atualidade, embora a pesquisa seja permeada por esse tema.

${ }^{68}$ O Instagram modificou seu layout em junho de 2019, durante o andamento desta pesquisa. O print screen do perfil mostrado na figura 2 foi capturado após esta data e, portanto, tem o novo layout, que permanece até a finalização desta dissertação, em agosto de 2020. Entretanto, como poderá ser observado nas próximas páginas, as capturas dos perfis profissionais de coaches de carreira foram feitas em maio de 2019 e apresentam o antigo layout do Instagram, no qual o IGTV e o botão de mensagem se encontram em outra posição. A mudança não prejudicou a análise e os objetivos da pesquisa. Mais informações disponíveis em: < https://www.techtudo.com.br/noticias/2019/06/instagram-muda-visual-do-perfil-vejacomo-fica.ghtml>. Acesso em: 10 nov. 2019.
} 
Figura 3 - perfil pessoal da pesquisadora no Instagram.

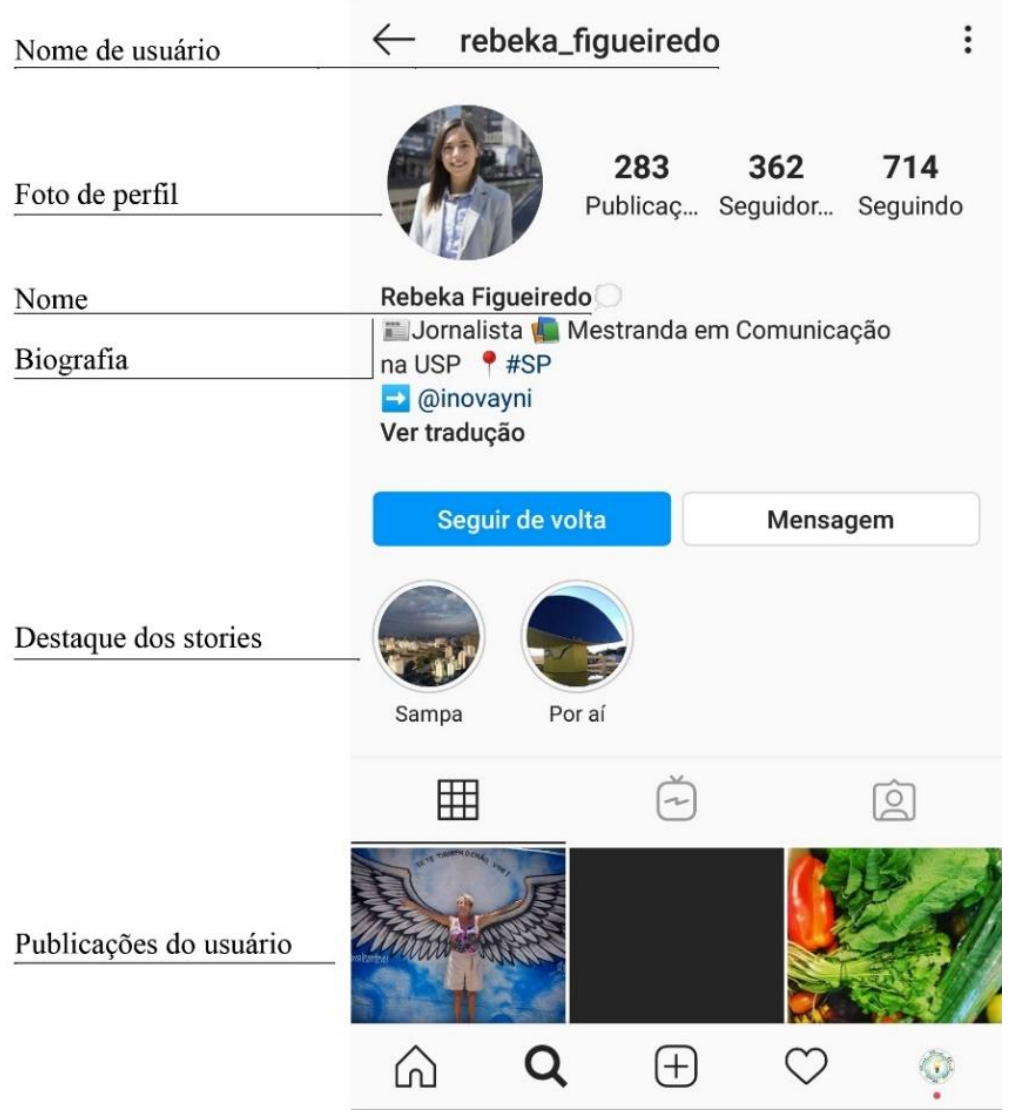

Fonte: print screen do Instagram da pesquisadora.

$\mathrm{Na}$ biografia, como pontuamos anteriormente, é possível adicionar hashtags e menções a outros perfis, que aparecem como hiperlinks. ${ }^{69}$ No caso acima, foram usadas a hashtag “\#SP” e a menção “@inovayni”. Outra opção é incluir emojis ${ }^{70}$, como os usados

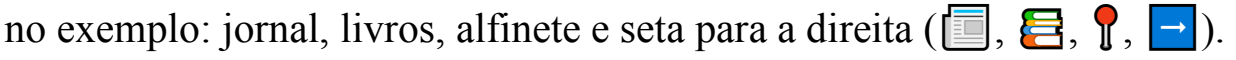

O nome de usuário é criado durante a abertura da conta e pode ser escolhido pela pessoa, desde que esteja disponível. Não é possível, por exemplo, criar um perfil no

\footnotetext{
${ }^{69}$ A palavra hiperlink (hiperligação) refere-se a qualquer conteúdo clicável em um site, tendo como função fazer referência a outra página ou conteúdo.

${ }^{70}$ Emojis são pictogramas digitais usados, em geral, para expressar ideias ou emoções, embora também possam atuar como índices. Alguns exemplos de emojis são: :-) E (2) A palavra emoji é resultado da junção de duas palavras em japonês: "e", que significa imagem, e "moji", que significa letra. (EMOJI, 2020). Os emojis foram criados no fim da década de 1990 pelo designer japonês Shigetaka Kurita para a empresa de telefonia móvel NTT DOCOMO. Posteriormente, eles passaram a ser usados por outras empresas, com a inclusão de novos emojis e algumas mudanças no aspecto visual, e hoje estão presentes em aplicativos de mensagem instantânea, redes sociais digitais e outros sites, etc. Mais informações em: $<$ https://www.moma.org/collection/works/196070>. Acesso em: 20 jul. 2020.
} 
Instagram com o nome de usuário “@gisele”, pois ele já existe e pertence à modelo Gisele Bündchen. O nome de usuário pode ser modificado a qualquer momento.

Na figura 3, o nome de usuário é “@rebeka_figueiredo”. Na seção nome, o Instagram sugere inserir o nome pelo qual a pessoa é conhecida, como nome completo, apelido ou nome comercial; além disso, é possível usar emojis. Em nosso exemplo, o nome é "Rebeka Figueiredo 1 ", ou seja, dois substantivos próprios e o emoji de balão de pensamento.

Além desses elementos, é possível incluir destaques, que são criados a partir dos conteúdos publicados originalmente nos Stories. Os usuários podem escolher o título que desejam dar ao destaque e personalizar a capa, adicionando uma imagem que esteja nos arquivos de seu smartphone. No exemplo acima, temos os destaques "Sampa" e "Por aí".

Abaixo dos destaques, é possível observar três ícones: o primeiro deles, à esquerda, indica o grid com todas as publicações de fotos e vídeos (de até um minuto) já feitas pelo usuário, podendo ser acessadas por outras pessoas; o do meio mostra o ícone do IGTV e reúne os vídeos de mais de um minuto publicados pelo usuário; e, por fím, o ícone à direita reúne as publicações de outros perfis em que o usuário foi marcado (ou mencionado).

O perfil pessoal pode ser: público, no qual os conteúdos ficam abertos e podem ser visualizados por qualquer pessoa, mesmo aquelas que não possuem conta no Instagram, além de poder ser encontrado em mecanismos de busca como o Google; ou privado, quando os conteúdos podem ser acessados apenas pelos seguidores (conexões) aprovados pelo usuário.

Já o perfil profissional é sempre público. Em relação à interface visível a outros usuários, há três diferenças principais, se comparado ao perfil pessoal: os botões de contato (opcionais), por meio dos quais o criador do perfil pode inserir o telefone, o email e modo de chegar ao seu endereço comercial; a possibilidade de incluir localização (opcional); e a categoria. Além disso, em maio de 2019, data da coleta dos perfis, os conteúdos de IGTV ficavam armazenados ao lado dos destaques, como pode ser observado na figura 4 . 
Figura 4 - perfil profissional no Instagram.
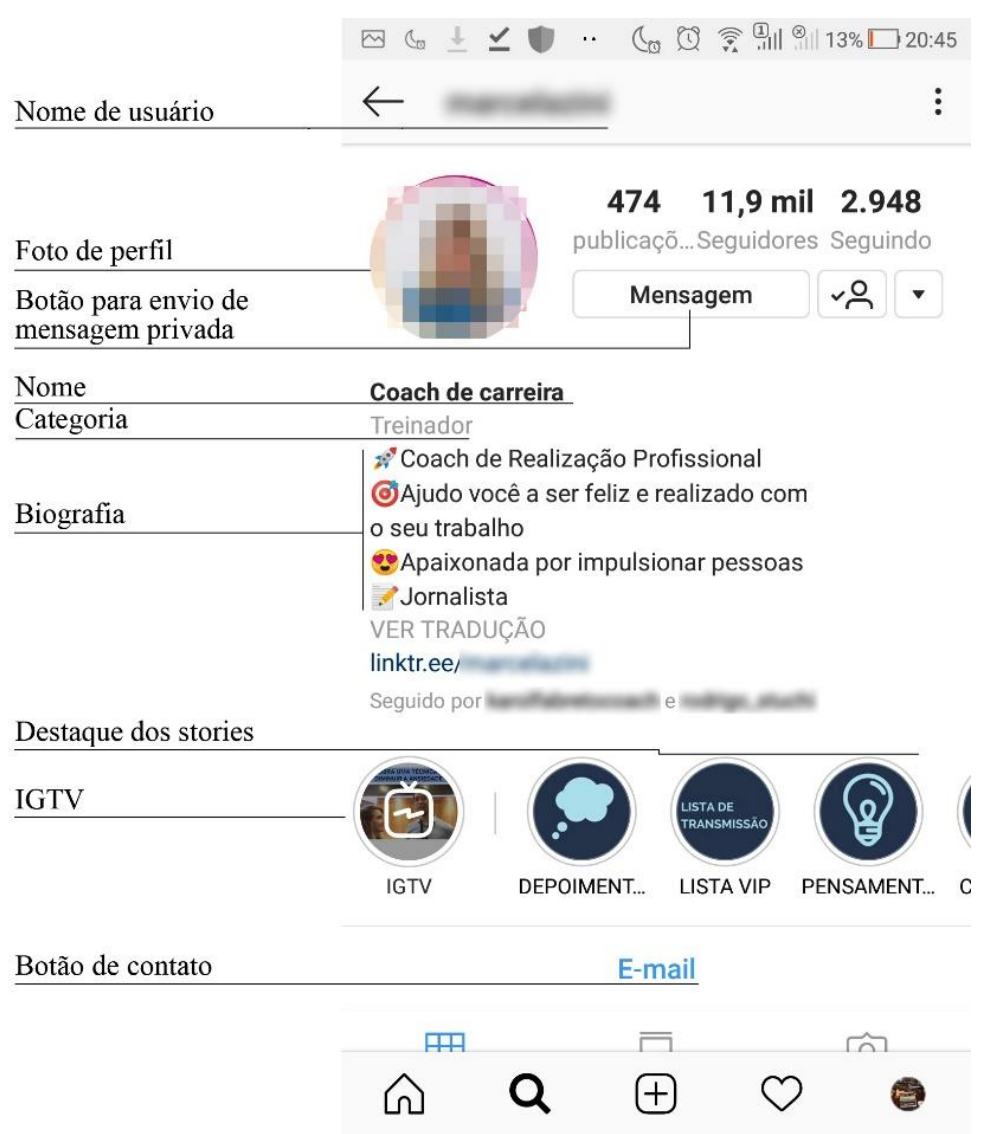

Fonte: print screen do Instagram da autora.

Ao criar um perfil profissional, os usuários devem selecionar a categoria à qual o perfil melhor se enquadra, dentre as opções fornecidas previamente pelo Instagram. No exemplo acima, a categoria escolhida é "Treinador".

Atualmente, é possível transformar o perfil pessoal em conta comercial, com duas opções: Criador de Conteúdo, recomendada para produtores de conteúdo, artistas, figuras públicas e influenciadores; e Empresa, voltado para varejistas, negócios locais, marcas, prestadores de serviços. Na opção criador de conteúdo, estão disponíveis as seguintes categorias: arquiteto(a); artista; atleta; ator/atriz; autor(a); blogueiro(a); candidato político; chef; cientista; criador de vídeo; criador de vídeo de jogos; criador(a) de conteúdo digital; dançarino; designer; designer gráfico; diretor de cinema; DJ; Editor; empreendedor(a); escritor(a); estilista de moda; estúdio de design de interiores; figura pública; fotógrafo(a); gamer; humorista; instrutor fitness; jornalista; modelo; modelo fitness; músico; músico/banda; notícias de personalidades; palestrante motivacional; 
personagem de filme; político; produtor; representante do governo; treinador; turnê; web designer.

Figura 5 - categorias do Instagram para perfis profissionais.

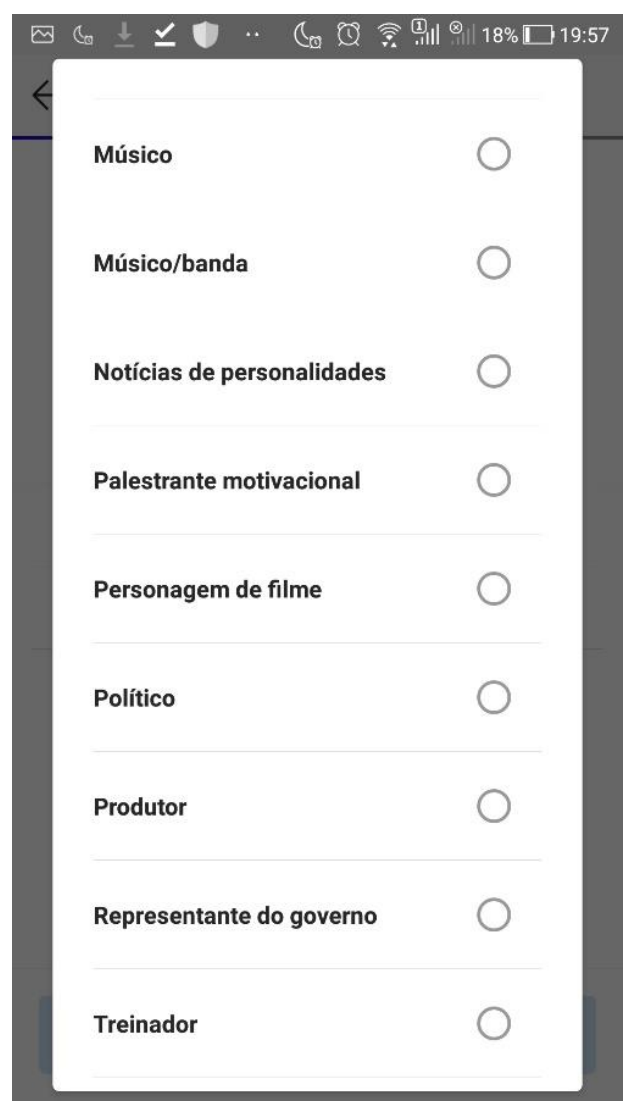

Fonte: print screen do Instagram da autora.

A escolha obrigatória de uma categoria sugere a tentativa de parametrização de perfis pela rede social, uma vez que o usuário passa a se representar com o apoio de tipos gerais fornecidos pelo Instagram.

\subsubsection{Feed}

O feed é a tela inicial do aplicativo e aparece em forma de lista, que pode ser acessada com movimentos do dedo para cima e para baixo; para ver mais publicações, basta tocar a tela com o dedo e arrastá-la para cima. 
Figura 6 - feed do Instagram.

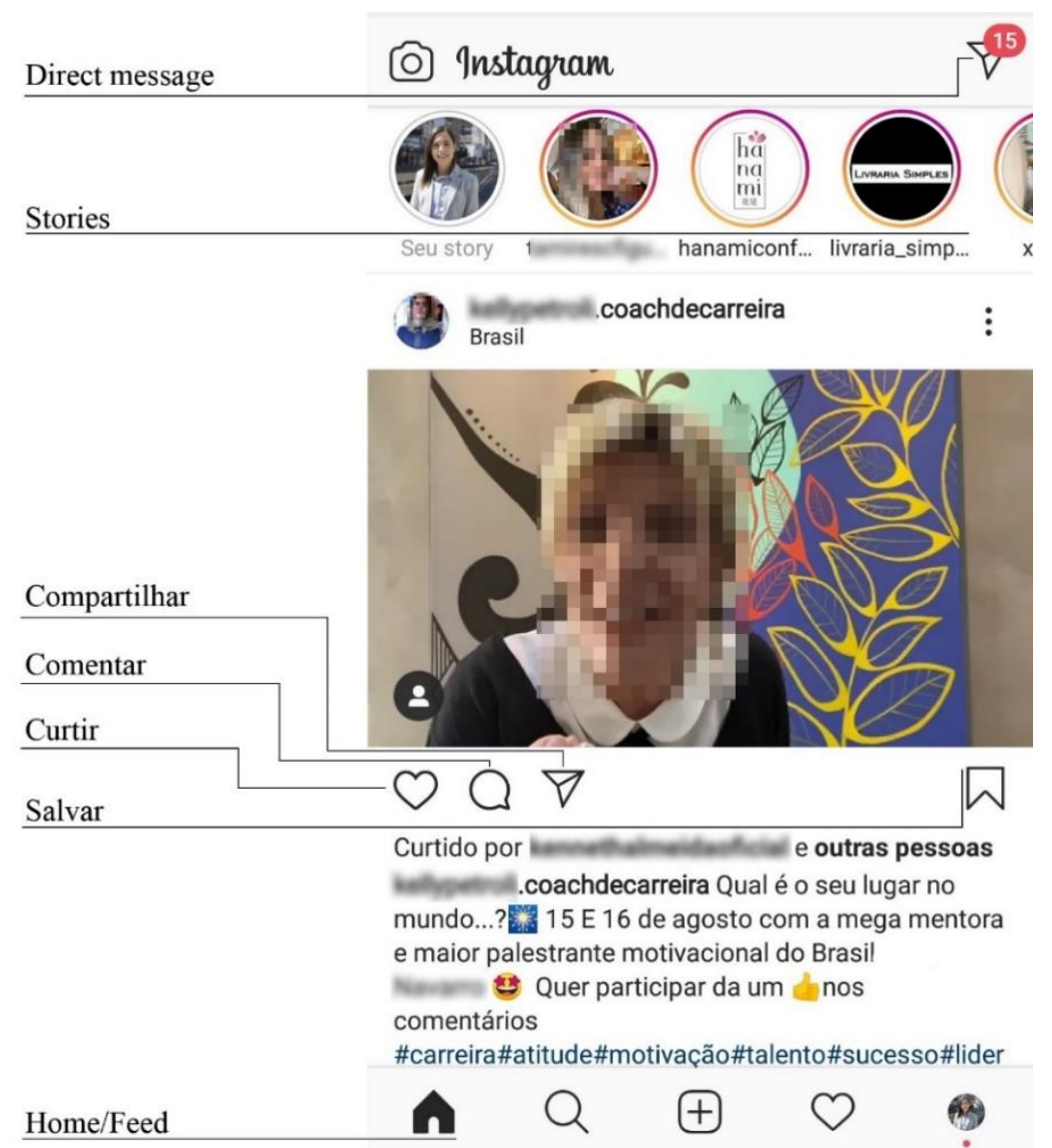

Fonte: print screen do Instagram da pesquisadora.

Em geral, é por meio do feed que os usuários entram em contato com os conteúdos publicados na plataforma e interagem com eles. Ao abrir o aplicativo do Instagram, o usuário encontra no topo os Stories feitos por outros perfis, que podem ser acessados com um clique em cima de cada imagem. Ao clicar no ícone disponível no canto superior direito, o usuário acessa as mensagens que recebeu de modo privado, via Direct Message. Já o ícone de câmera fotográfica, localizado no canto superior esquerdo da imagem, é um atalho para a publicação de Stories. Ao clicar nele, o usuário pode criar e compartilhar um conteúdo, incluindo fotos, hashtags, gifs, menções a outros perfis e figurinhas que permitem interações, entre outras possibilidades. Como pode ser observado na figura 6 , as principais formas de interação na rede são: curtir um conteúdo (ao clicar no ícone de coração); comentar (para fazer um comentário público, acessível a outros usuários, bastando, para isso, clicar no ícone de balão e escrever em seguida), compartilhar (no próprio story) e salvar a publicação (a qual passa a fazer parte de uma coleção privada, podendo ser acessada no menu principal do perfil). 
O exemplo abaixo mostra uma publicação no Story que conta com figurinha de enquete (que permite fazer interações com outros usuários por meio de perguntas), foto de estante de livros, gif de um cérebro comendo livros, menção ao perfil “@usp.oficial” e hashtag "\#mestrado":

Figura 7 - exemplo de publicação no Story.

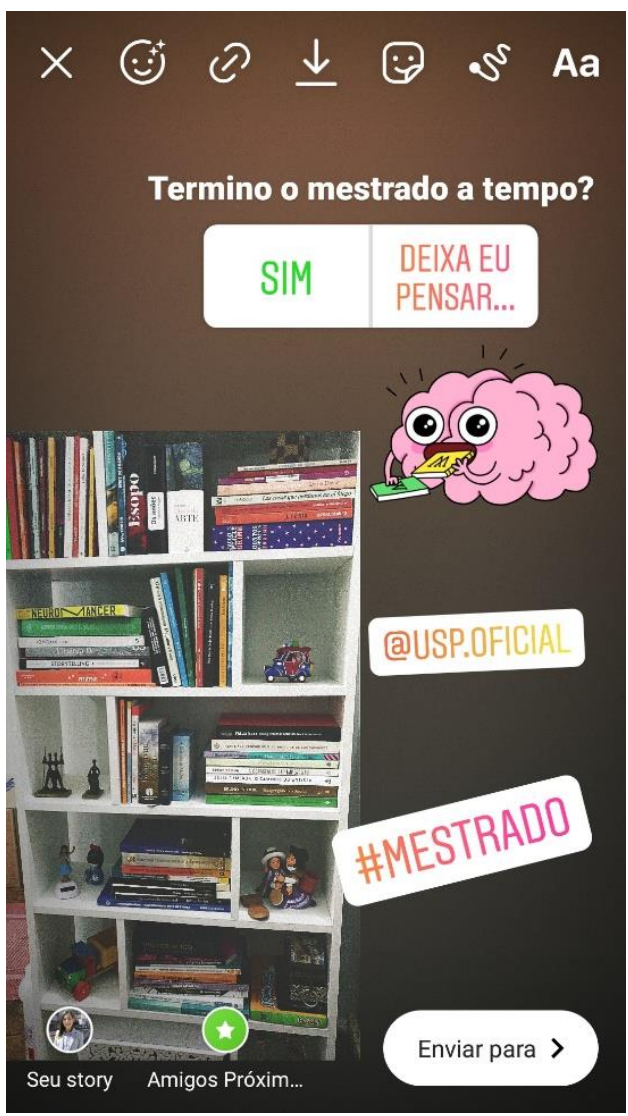

Fonte: print screen do perfil da pesquisadora.

Nos Stories, é possível comentar ou interagir com figurinhas, como responder enquetes, enviar perguntas, fazer testes de múltipla escolha, ou clicar em hashtags e menções.

Outro modo de interação é o envio de mensagem direta; para isso, é preciso ir ao perfil com o qual se deseja interagir de modo privado e clicar no botão "Mensagem". Ao clicar nos três pontos no canto superior direito (figura 8), o usuário pode: denunciar a publicação; ativar notificações de publicação, para receber avisos sobre novos comentários; copiar o link, que pode ser usado fora da rede; compartilhar, que permite o compartilhamento do link em serviços externos ao Instagram, como o WhatsApp e o 
Gmail; deixar de seguir; e silenciar (quando não se deseja mais ver as publicações do perfil, sem deixar de seguí-lo).

Figura 8 - Outras formas de interação com postagens no feed.

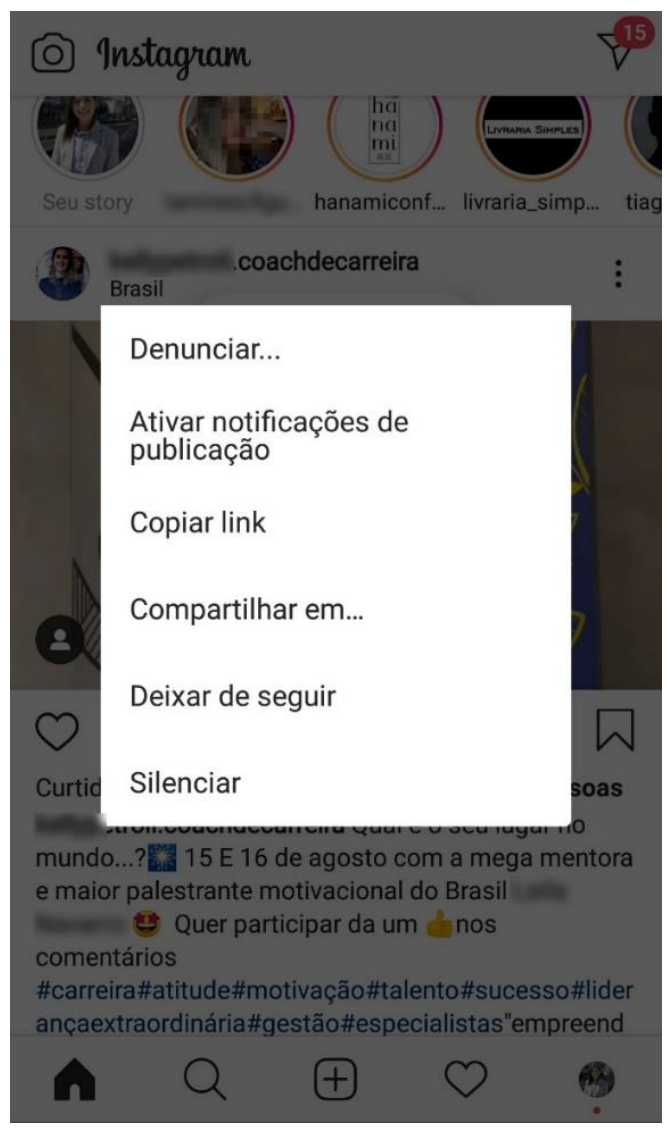

Fonte: print screen do Instagram da pesquisadora.

As interações são importantes para a geração de sentidos relacionada às autorrepresentações, pois, como sugere a política de dados da rede (INSTAGRAM, 2019a), elas ajudam a definir a distribuição das publicações. Assim, quanto mais interações o perfil obtiver, mais ele será avaliado como relevante dentro dos critérios do Instagram e, assim, suas publicações serão exibidas a um maior número de feeds dentre suas conexões. Em página do site dedicada a criadores de conteúdo, o Instagram destaca que "ter uma comunidade envolvida é fundamental para o sucesso no Instagram. Interaja com os fãs utilizando Stories, feed, IGTV e Live para manter a conversa rolando." (INSTAGRAM, 2019b). A rede ainda sugere que os usuários curtam e respondam comentários recebidos. Nesse sentido, é importante observar nas autorrepresentações de profissionais que estratégias foram usadas na tentativa de gerar interações. 
Hoje, o feed exibe publicações feitas há mais de um dia, mesclando postagens recentes com outras mais antigas; além disso, o usuário não visualiza no feed todas as postagens dos perfis que segue, uma vez que os algoritmos da rede orientam o que será mostrado na tela. Cada usuário tem acesso a um feed personalizado, com base nos perfis seguidos, nas interações que realiza e nos interesses pessoais, entre outros. Além de publicações de perfis seguidos, o usuário pode visualizar em seu feed publicações marcadas com as hashtags que ele segue e anúncios, que aparecem indicados com a palavra "Patrocinado":

Figura 9 - exemplo de publicação paga no feed do Instagram.

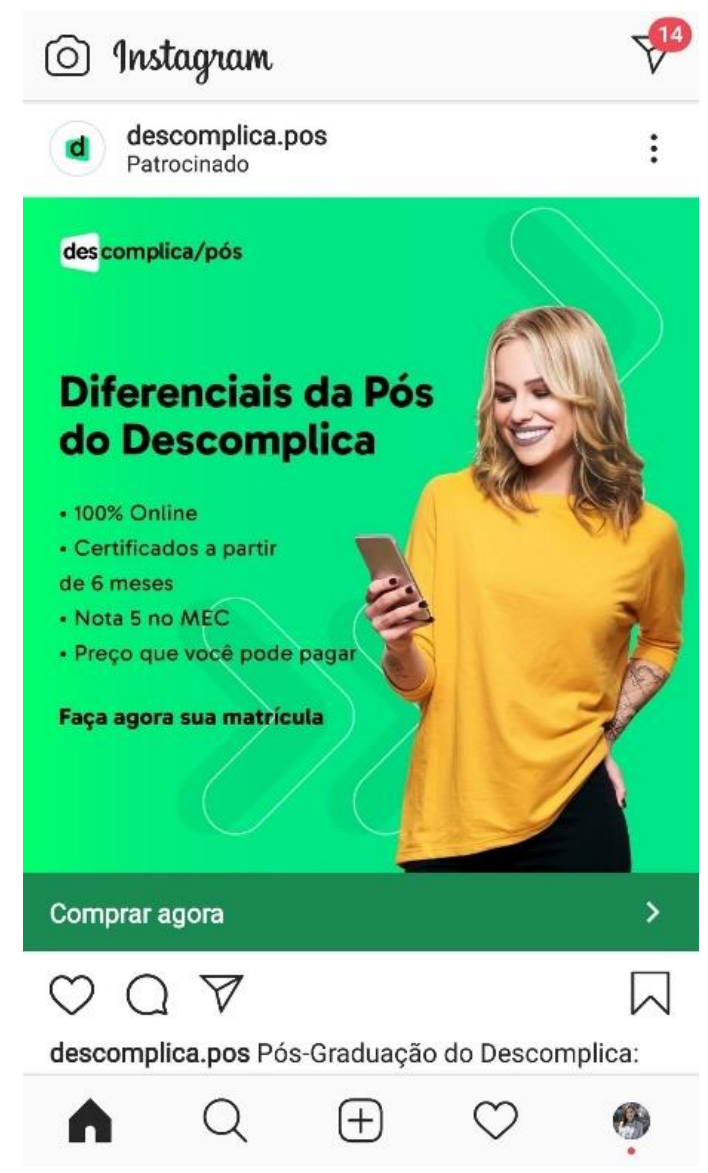

Fonte: print screen do Instagram da pesquisadora.

\subsubsection{Explorar}

A seção Explorar permite que o usuário busque perfis e conteúdos de seu interesse. Ao acessá-la, o usuário encontra um mosaico de imagens personalizadas para o seu perfil, com base no que o Instagram considera mais relevante. Também é possível 
navegar por conteúdos a partir de categorias pré-estabelecidas pelo Instagram, clicando em cima de cada uma delas. As categorias são: IGTV, Loja, Viagem, Arquitetura, Decoração, Arte, Comida, Estilo, TV e cinema, Faça você mesmo, humor, beleza, música.

Figura 10 - seção Explorar do Instagram.

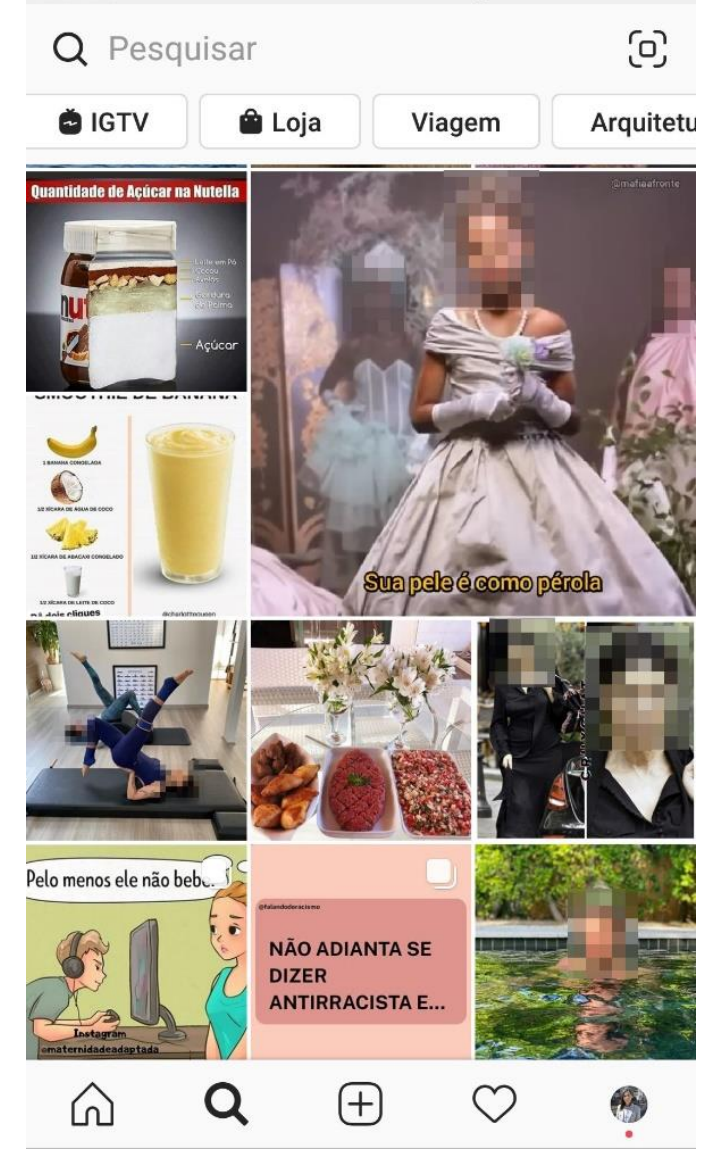

Fonte: print screen do Instagram da pesquisadora.

No canto superior esquerdo, ao lado do ícone de lupa, digita-se a palavra-chave relacionada ao tema de interesse e o Instagram exibe os resultados mais alinhados ao perfil que realiza a busca (figura 11). Os resultados podem ser ordenados por: principais (que reúne fotos e vídeos); contas (que apresenta perfis relacionados à palavra-chave pesquisada); tags (que apresenta publicações marcadas com hashtags criadas com a palavra-chave da busca); e locais. 
Figura 11 - pesquisa da palavra coach na ferramenta Explorar.

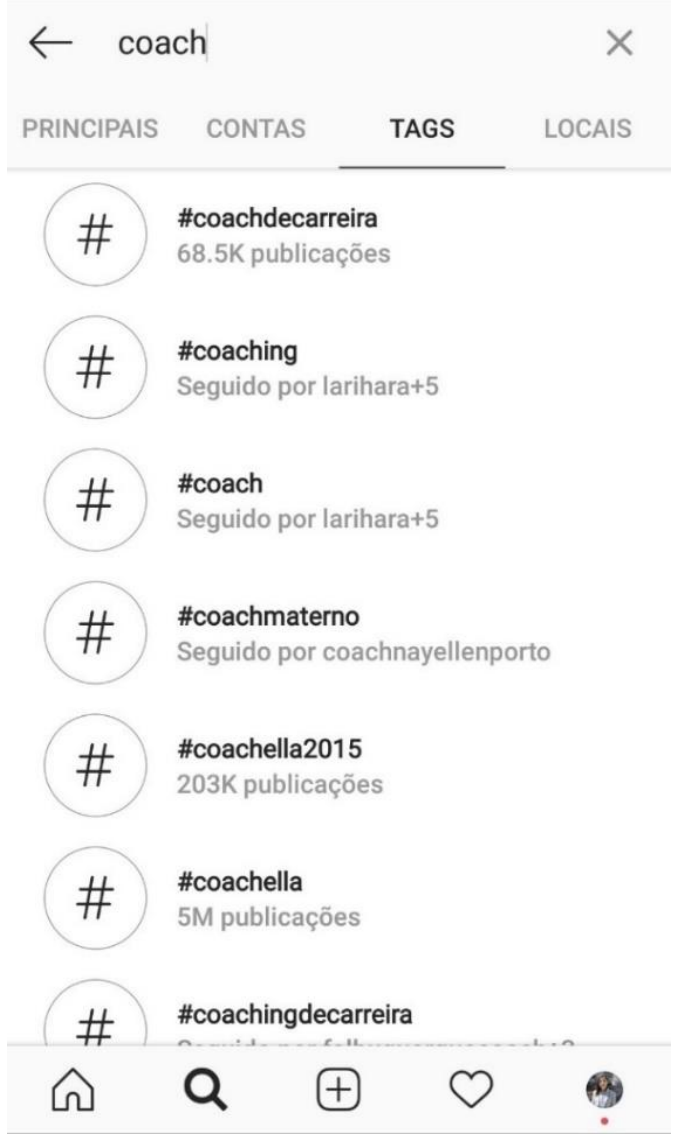

Fonte: print screen do Instagram da pesquisadora.

\subsubsection{Publicações}

Aqui, destacamos os recursos oferecidos pelo Instagram para fazer publicações no feed, pois analisaremos algumas postagens feitas por coaches de carreira em seus feeds. Para fazer uma postagem no feed, o usuário deve clicar inicialmente no botão central da interface $(+)$ e, em seguida, fazer uma foto ou um vídeo com a câmera do aplicativo, ou, ainda, escolher uma imagem que já esteja armazenada na galeria de seu smartphone. Na segunda etapa, o usuário pode optar por um dos filtros oferecidos pelo Instagram e/ou fazer outras edições na imagem, como ajuste de contraste, brilho e cores. As duas primeiras etapas podem ser observadas na figura 12 . 
Figura 12 - primeira e segunda etapas de publicação no feed do Instagram.

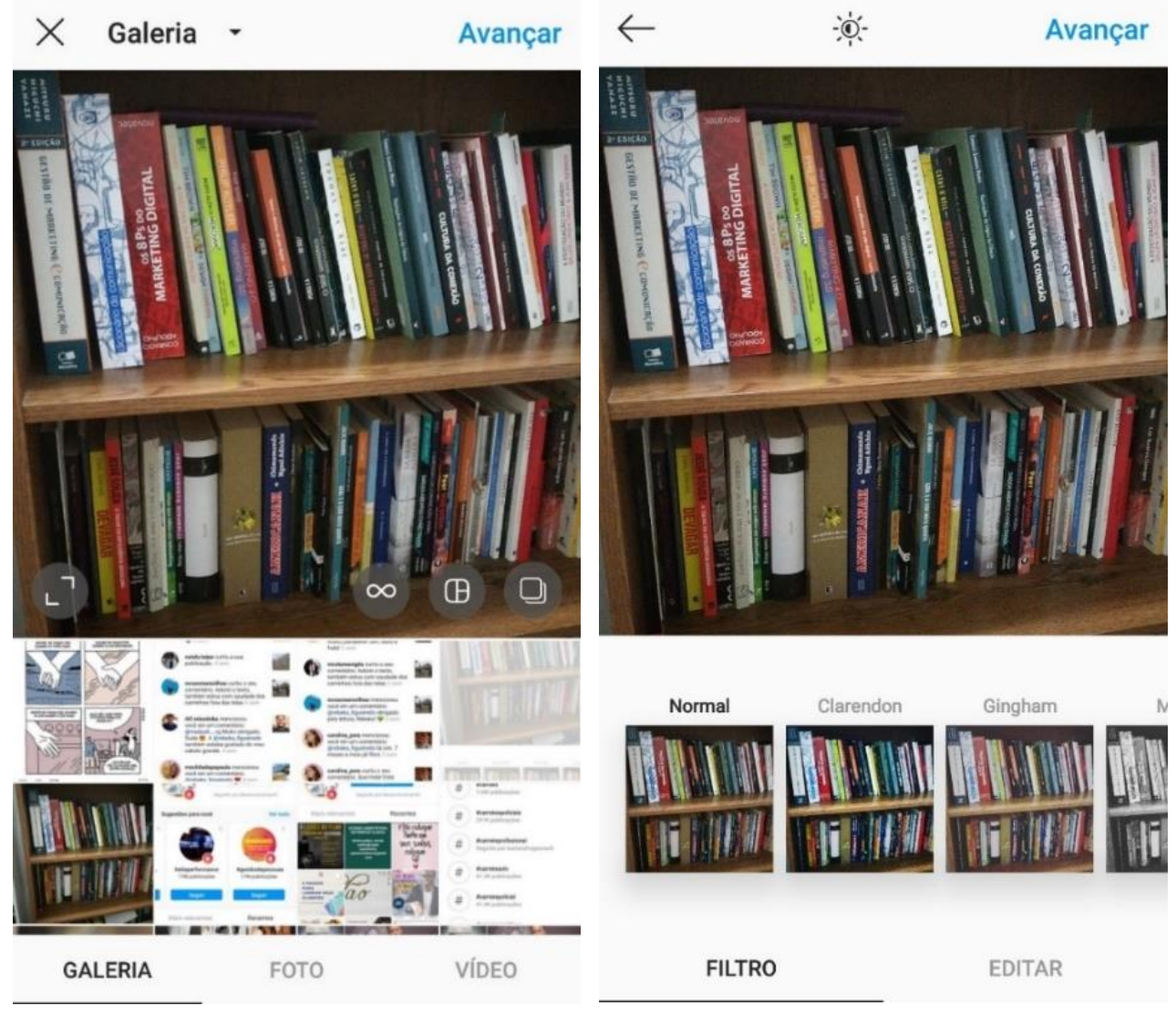

Fonte: print screen do Instagram da autora.

Por fim, o usuário pode escrever uma legenda de até 2.200 caracteres, incluindo, se desejar, hashtags, emojis e menções a outros perfis. Também é possível marcar outros perfis (opcional), adicionar localização (opcional), e publicar a imagem em outra rede social como Facebook e Twitter (opcional), como pode ser observado na figura 13. Em configurações avançadas, é possível desativar comentários e marcar parcerias com marcas. 
Figura 13 - terceira etapa de publicação no feed do Instagram, a escrita da legenda, a marcação de perfis e a opção de inserir localização e/ou publicar em outras redes.

$\leftarrow$ Nova publicação Compartilhar
Marcar pessoas
Adicionar localização
Publicar também em
Facebook
Twitter
Tumblr
Configuraçōes avançadas

Fonte: print screen do Instagram da autora.

Após definir quais elementos estarão presentes na publicação (legenda, marcação, localização, etc.) e clicar em compartilhar, a postagem é publicada no feed e distribuída para algumas conexões do perfil, de acordo com os critérios do Instagram.

Na figura 14, a postagem é composta por uma foto que mostra parte de uma estante com livros, acompanhada da legenda "Este é um exemplo de postagem para o \#mestrado

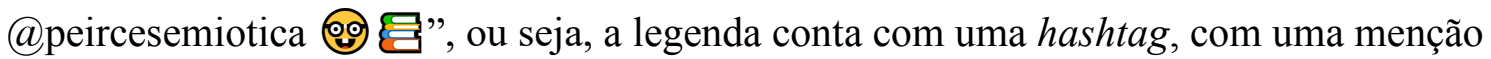
a outro perfil (@peircesemiotica) e dois emojis. Ela ainda traz a localização "São Paulo" e a marcação do perfil @peircesemiotica. 
Figura 14 - exemplo de publicação no Instagram com legenda, marcação de perfil e indicação de localização.

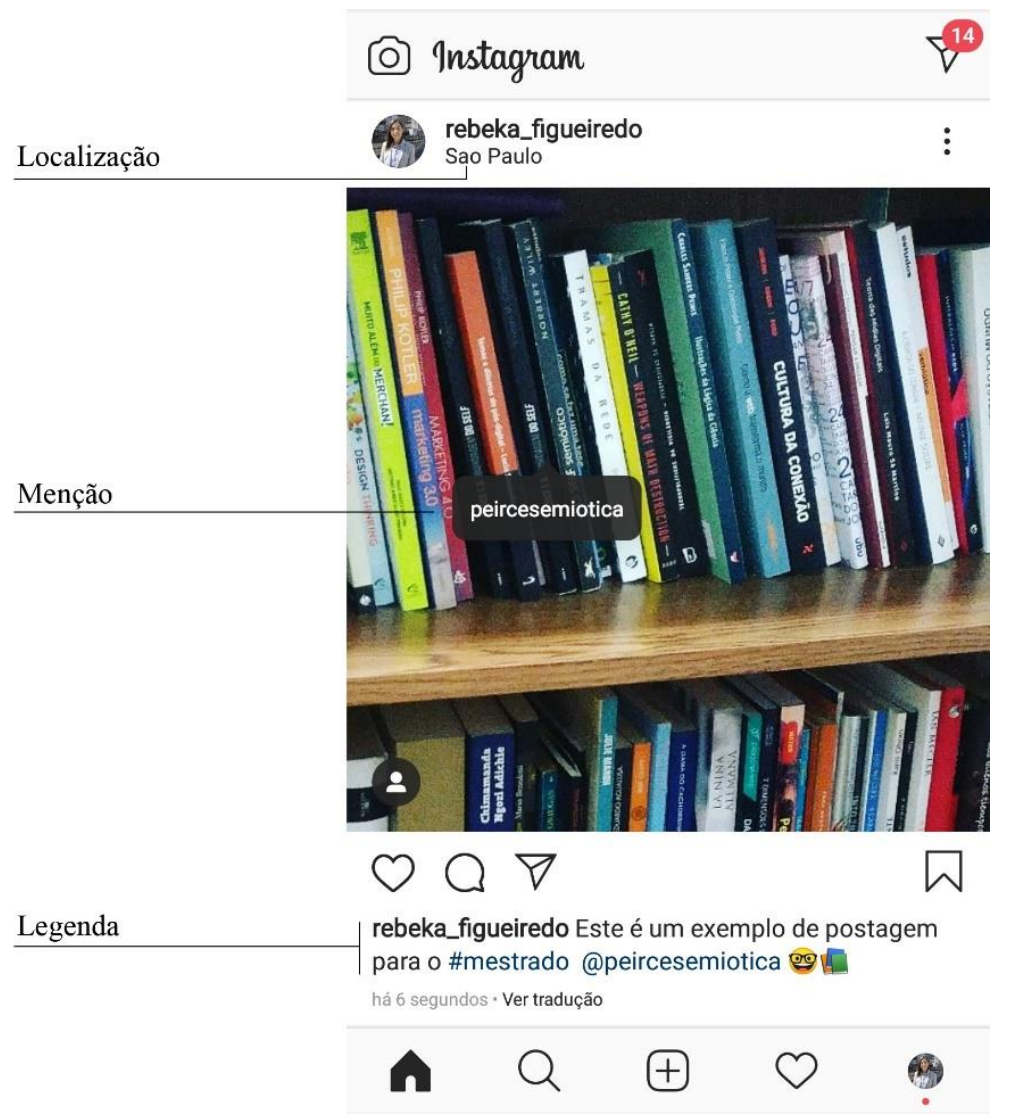

Fonte: print screen do Instagrsm da pesquisadora.

Nos perfis profissionais de coaches de carreira no Instagram, analisaremos algumas publicações observando, além do conteúdo visual, as possíveis escolhas de hashtags, emojis, menções e localização. O objetivo é entender como cada um desses signos funciona na semiose, ou seja, de que modo eles contribuem para a geração de significados relacionados às autorrepresentações.

Após publicar um conteúdo no feed, o usuário recebe notificações sobre as interações que o conteúdo obteve na aba Atividade, identificada com um coração. Esta seção também mostra os novos seguidores do perfil, bem como as menções que o perfil recebeu em publicações de outros usuários. A seção Atividade não será considera em nossa análise, pois ela é privada, ou seja, apenas o dono do perfil tem acesso. 


\subsubsection{Hashtags e outros links}

É importante destacar as diferentes funções que as hashtags e os links (por meio de menções a outros perfis e indicação de localização) podem ocupar atualmente no funcionamento do Instagram, de acordo com o modo como são usados. As hashtags e as menções (hiperlinks) podem ser adicionadas pelo usuário ao publicar um conteúdo em diferentes espaços da interface: no feed, nos Stories, no IGTV, na biografia, e ao fazer comentários nas próprias publicações e nas de outros perfis.

Ao clicar em uma hashtag, o usuário é direcionado a uma coleção de conteúdos de diferentes perfis que foram etiquetados com a mesma hashtag; do mesmo modo, quando uma publicação recebe uma hashtag, ela passa a fazer parte de um conjunto de publicações etiquetadas com a referida hashtag. Ao organizar e conectar conteúdos, as hashtags operam na categorização de dados, tornando-os rastreáveis por outros usuários e pelas lógicas internas da rede.

Em artigo que discute a função mediadora das hashtags no Twitter e no Facebook, Alzamora e Bicalho (2016, p. 118), pontuam que "as hashtags conformam processos de mediação que envolvem ações humanas e algorítmicas na produção e na circulação de informações em rede intermídia". As hashtags integram, assim, ações humanas e nãohumanas em distintos processos de representação. Do ponto de vista da Semiótica Peirceana, podemos afirmar ainda que, ao conectar conteúdos, essas hashtags funcionam como índices e, nesse sentido, evidenciam o aspecto indicial nas trocas no Instagram.

Para seguir hashtags, o usuário deve procurar um assunto de seu interesse na aba Explorar ou tocar na hashtag de uma publicação. Depois, deve abrir a página da hashtag com um clique e tocar no botão "seguir", operação que pode ser desfeita a qualquer momento. (INSTAGRAM, 2017). 
Figura 15 - página da hashtag \#realização.

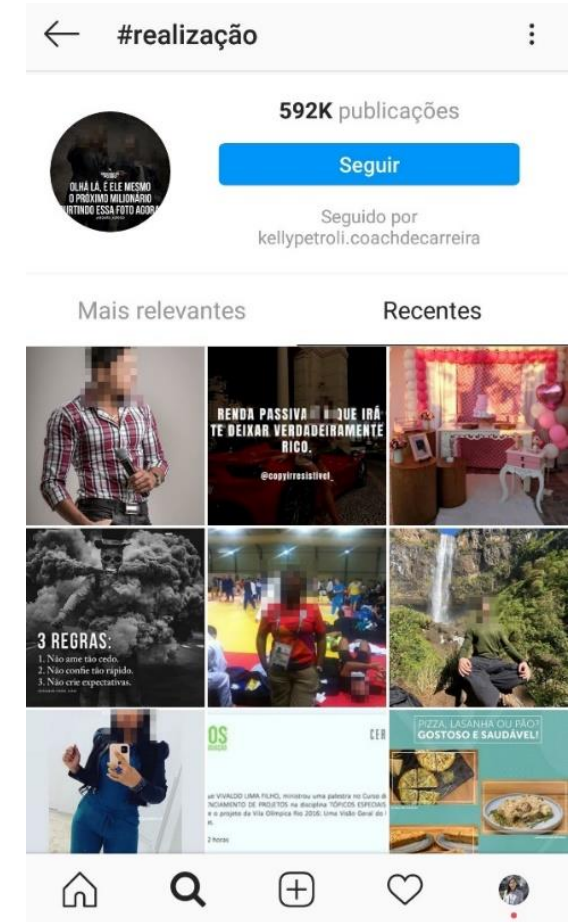

Fonte: print screen do Instagram da pesquisadora.

Ao seguir uma hashtag, o usuário passa a ver em seu feed conteúdos relacionados a ela, sem a necessidade de seguir os perfis responsáveis por publicá-las (figura 16).

Figura 16 - publicação no feed a partir da hashtag \#realização.

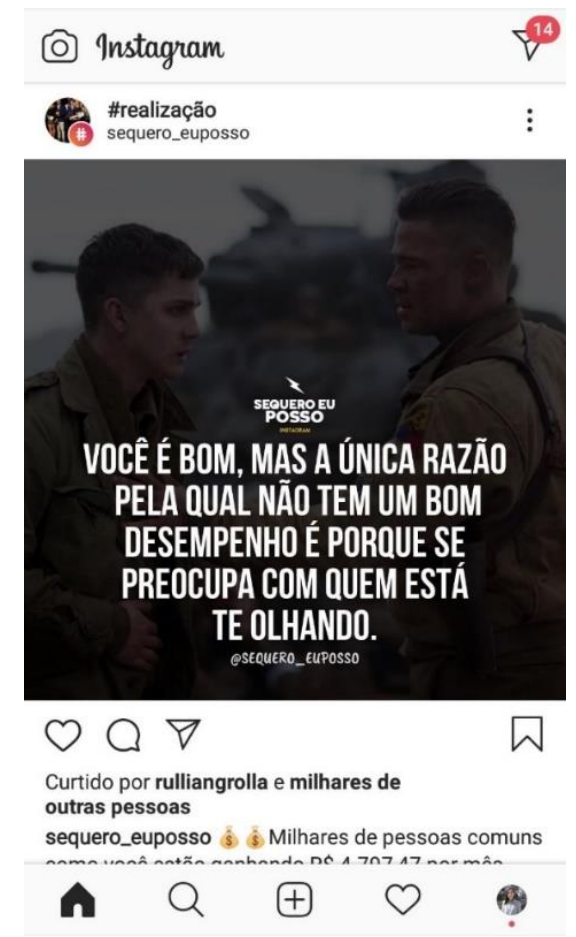

Fonte: print screen no Instagram da pesquisadora. 
As hashtags e as menções a outros perfis (por meio do @) incluídas na biografia do perfil tornam-se links clicáveis, possibilitando, assim, a vinculação do perfil a esses links e o direcionamento para a página da hashtag escolhida ou para o perfil mencionado. De acordo com a rede, "com a hashtag e os links do perfil na biografia, você pode se expressar e destacar seus interesses diretamente no perfil.” (INSTAGRAM, 2018). Entendemos que ao adicionar uma hashtag e/ou uma menção ao próprio perfil, o usuário estaria contribuindo para o ajuste de sua representação às tipificações do Instagram, facilitando o enquadramento do perfil às dinâmicas e às análises de dados feitas pela rede. Ao mesmo tempo, o uso de uma hashtag pode permitir que o perfil seja mais facilmente encontrado por pessoas que estejam buscando conteúdos relacionados à palavra-chave da hashtag, garantindo, assim, mais visibilidade e mais possibilidades de semiose. Por fim, a escolha de hashtags pode sugerir o alinhamento aos valores simbólicos que elas representam, como o próprio Instagram propõe no excerto acima, ao indicar a possibilidade de "expressar-se" por meio delas. Nesse sentido, as hashtags podem cumprir mais de uma função ao mesmo tempo, bem como atuar em distintas funções, de acordo com o contexto em que se inserem.

Alzamora e Bicalho (2016) demonstram que a hashtag, compreendida como signo, relaciona-se com o objeto que a determina em três domínios de representação:

Em nível de primeiridade fenomenológica, o signo relativo ao objeto que o determina é um ícone porque remete a uma qualidade que compartilha com seu objeto. A qualidade do objeto apresenta-se no signo por analogia ou metáfora, nível bastante rudimentar de representação. Em domínio fenomenológico de secundidade, o signo opera em relação existencial com o seu objeto, em conexão física, estabelecendo com ele uma relação de alteridade. [...] Quando a repetição indicial se torna regra, envolve nível de terceiridade, operando como hábito, norma. Em nível de terceiridade, o signo se refere ao seu objeto por força de uma lei, uma convenção, tornando-se símbolo. (ALZAMORA; BICALHO, 2016, p. 109-110).

A partir das considerações das autoras supracitadas e das observações feitas por nós até aqui, admitimos que as hashtags podem produzir distintas formas de representação no Instagram, de acordo com o contexto em que se inserem. Assim, buscaremos compreender de que modo as hashtags operam nos perfis de coaches de carreira. 


\section{UM ESTUDO DAS AUTORREPRESENTAÇÕES DE COACHES DE CARREIRA NO INSTAGRAM}

Este capítulo está dedicado à explanação de nossas escolhas metodológicas e suas implicações para as decisões tomadas em distintas etapas da pesquisa. Ponderamos que a metodologia deste trabalho não se limita a esta seção, uma vez que adotamos aqui, em consonância com Lopes (2014) e com a perspectiva semiótica, uma visão não tecnicista de método.

Também faz parte deste capítulo a análise de perfis profissionais de coaches de carreira no Instagram, a partir das discussões realizadas nos capítulos anteriores. Nesse sentido, apresentamos detalhes sobre a seleção e a coleta de dados, bem como sua descrição e os resultados da análise. Outrossim, há uma breve exposição sobre a área de coaching no Brasil, com detalhes sobre a atividade de coaches de carreira, com o objetivo de obter subsídios para o estudo.

\subsection{Metodologia}

A metodologia da presente pesquisa foi construída a partir da Semiótica Peirceana, sobre a qual discorremos principalmente no primeiro capítulo, e das reflexões propostas por Lopes (2014). Nesse sentido, ela não se resume a técnicas e métodos, mas faz parte de um conjunto de escolhas que começaram a ser tomadas desde o início da investigação, a partir de decisões teóricas e da exploração inicial das representações da subjetividade em redes sociais digitais orientadas por nossas inquietações.

Para investigar as autorrepresentações que emergem a partir de perfis de profissionais no Instagram, reconhecemos, desde o princípio, que nossa abordagem deveria estar aberta a ajustes e exigências do próprio objeto. Por conseguinte, buscamos uma metodologia em processo, capaz de associar o rigor científico ao caráter criativo e aberto da investigação, evitando, assim, modelos rígidos e reducionistas. Conforme argumenta Lopes (2014),

Seguindo uma noção ampla e não tecnicista de método, este aparece como uma série de opções, seleções e eliminações que incidem sobre todas as operações metodológicas no interior da investigação: na definição do problema da pesquisa, na formulação de hipóteses, na teorização de conceito e, o que é menos óbvio, na construção dos dados. (LOPES, 2014, p. 101). 
Entendemos que essa noção ampliada de metodologia é adequada aos objetivos propostos nesta pesquisa, uma vez que nossa investigação não está centrada em um acontecimento passado ou fato imutável, mas consiste, sobretudo, no mapeamento de um objeto em constante transformação, com vistas a ampliar a compreensão sobre o mesmo.

Peirce reconhece a importância do método, mas destaca que este deve permitir a condução da pesquisa sem impedimentos, como fica claro em sua máxima: "não bloquear o caminho da investigação" (CP 1:135). Assim, a metodologia, em vez de impor restrições, deve permitir o avanço do conhecimento e, para isso, precisa estar aberta para reajustar seu curso.

Como evidenciamos nas seções anteriores desta dissertação, as autorrepresentações construídas no ambiente digital estão envoltas em processos semióticos complexos que reúnem distintos atores, dinâmicas e contextos indissociáveis dos aspectos técnicos do espaço virtual, estando sujeitas à mudanças imprevisíveis. Assim, para apreendê-las de modo que pudessem ser analisadas sem que incorrêssemos em uma abordagem positivista, buscamos aportes da perspectiva semiótica, uma vez que esta pressupõe a exploração do objeto de modo que se evidenciem suas distintas possibilidades de sentido, sem a pretensão de obter conclusões definitivas, como destaca Iasbeck (2017):

Trabalhar semioticamente um objeto de pesquisa significa relacioná-lo com o maior e o mais significativo número e natureza de possibilidades que ele comporta, buscando compreendê-lo em movimento, dinâmico e operante, ainda que tais relações possam, eventualmente, estabelecer paradoxos incontornáveis. (IASBECK, 2017, p. 203).

Deste modo, optamos por traçar distintas possibilidades de investigação das autorrepresentações, explorando-as por meio de pesquisa bibliográfica, do acompanhamento de perfis de coaches de carreira e do uso diário do Instagram por meio do perfil pessoal da pesquisadora, além da investigação dos contextos socioeconômico e cultural em que a construção de perfis digitais se insere. Isso nos permitiu ajustar as hipóteses e fazer o recorte do objeto.

Em consonância com Lopes (2014), concordamos que o objeto científico não está dado na realidade, mas emerge a partir da problematização da realidade feita com base em supostos teóricos e operações próprias do processo de pesquisa. Ou seja, é preciso diferenciar o objeto da realidade do objeto de ciência. Por conseguinte, o objeto não pode 
ser delimitado apenas pela observação empírica, sob o risco de se incorrer no erro de considerar que a realidade é transparente e facilmente apreendida.

\begin{abstract}
É indispensável renunciar a querer encontrar nos dados imediatamente percebidos um princípio que os unifique. Isso quer dizer que a necessidade do recurso aos modelos teóricos está em sua capacidade de formular os princípios geradores e unificadores de um sistema de relações. Abre-se a possibilidade de extrapolar as diversidades da realidade fenomenal e atingir as homologias estruturais, sem que se dispense a obrigação de procedimentos de verificação sistemática. (LOPES, 2014, p. 123).
\end{abstract}

A autora indica que o objeto é um sistema de relações marcado pelo ponto de vista do pesquisador e por questões impostas aos fatos da realidade, com base em métodos e técnicas de pesquisa. Nesse sentido, Lopes (2018, p. 19) alerta que, em vez de se buscar a objetividade como oposta à subjetividade, deve-se empreender um "[...] processo continuado de objetivação da subjetividade", por meio de esforços teóricos e conceituais capazes de clarificar as condições em que a pesquisa é realizada.

Como em toda pesquisa inserida no campo das ciências humanas, reconhecemos que esta investigação parte de bases teóricas e metodológicas oriundas de nossas decisões e que, portanto, estão em alguma medida ancoradas em visões de mundo e escolhas subjetivas que poderão ser transpostas aos resultados. Procuramos minimizar o risco da imposição de nossos vieses à análise a partir do exercício da reflexividade epistêmica sugerida por Lopes (2018), exercida a partir da crítica e da autorreflexão sobre todos os atos da pesquisa.

Nosso foco são os processos de autorrepresentação e circulação de sentidos no ambiente digital. Por isso, esta investigação não poderia ser traduzida em números, ou seja, nossos objetivos não seriam alcançados por meio de uma simples quantificação de dados coletados a partir de perfis de coaches de carreira no Instagram. Tampouco a pergunta de pesquisa seria respondida por análises realizadas por softwares. Nessa perspectiva, optamos por uma abordagem qualitativa, que se reflete na escolha de uma amostra não probabilística, ou seja, sem tratamento estatístico (LOPES, 2014, p.145).

A pretensão aqui não é fazer generalizações sobre o modo como coaches de carreira se autorrepresentam em redes sociais digitais, uma vez que nossa investigação se concentra em um fenômeno em constante mutação, que envolve variáveis humanas e nãohumanas (algoritmos, interações entre usuários, políticas de plataformas, etc.). Entretanto, acreditamos que a análise de particularidades dos perfis de coaches no 
Instagram nos permite discorrer sobre a lógica das operações semióticas e exemplificar como a Semiótica Peirceana pode fornecer subsídios adequados ao estudo dos processos de autorrepresentação em ambientes digitais sob a ótica da Comunicação.

Feitas essas considerações, detalhamos a seguir o modo como as ferramentas teórico-metodológicas foram usadas em nossa análise. Um dos grandes desafios da Teoria Semiótica está justamente em sua aplicação, uma vez que ela não oferece modelos préprontos, mas deve ser pensada junto com as possibilidades do objeto. Sobre o método semiótico, Iasbeck (2017, p. 203) esclarece que este se desenvolve "[...] em estratégias de percepção e apreensão para, finalmente, ser equacionada segundo bases epistemológicas vigorosas que não necessitam parar a ação do objeto para detê-lo didaticamente”. De fato, a Semiótica não permite uma aplicação isolada de outras etapas da pesquisa, mas requer uma observação atenta, capaz de equacionar os diferentes obstáculos que se apresentam à medida em que o objeto vai sendo desvendado e compreendido.

Com base na apresentação dos principais conceitos da Semiótica Peirceana feita no primeiro capítulo, reconhecemos que a análise do objeto a partir das categorias fenomenológicas é fundamental para a compreensão dos processos de produção de sentidos. Assim, buscamos, em nossa análise, identificar elementos de primeiridade, secundidade e terceiridade nos perfis e nas dinâmicas do Instagram. Conforme evidencia Almeida (2013), uma vez que a Fenomenologia está voltada ao estudo dos modos de ser da experiência, observar o objeto do ponto de vista de sua forma fenomenológica permite identificar os modos como se dão as experiências no ambiente digital, considerando suas potencialidades, a materialização de diferentes signos e as mediações estabelecidas pelos vínculos que se formam e se transformam a todo momento junto com os movimentos dos sujeitos e dos diferentes elementos que se inter-relacionam no espaço virtual.

A geração de significados se dá por meio da relação entre signos, e, como pontuamos ao longo do segundo capítulo, os ambientes digitais são compostos por signos de distintas naturezas. Nesse sentido, nossa análise considera também os aspectos de iconicidade, indexicalidade e simbolicidade dos signos presentes nos perfis. Entretanto, o objetivo não é encaixar ou classificar os signos em categorias estanques, mas evidenciar os papéis prioritários que eles desempenham nos processos de representação, com base no recorte proposto. Ao diferenciar ícones, índices e símbolos, Peirce (2017) esclarece que um signo pode conter partes icônicas, indiciais e simbólicas e sua classificação depende de como ele atua na semiose analisada: 
Quando um cocheiro, para atrair a atenção de um pedestre e fazer com que ele se afaste, grita 'Ei!', esse grito, na medida em que é uma palavra significativa, [...], é algo mais do que um índice; porém, na medida em que se pretende que apenas atue sobre o sistema nervoso do ouvinte de modo a levá-lo a sair do lugar, é um índice, dado que se pretende colocálo numa conexão com o objeto, que é sua situação relativa ao veículo que se aproxima. (PEIRCE, 2017, p. 68).

É sob essa perspectiva que consideramos os aspectos de iconicidade, indexicalidade e simbolicidade nos perfis analisados.

Outrossim, a análise considera os seis aspectos fundamentais das operações semióticas, quais sejam, o signo, o objeto dinâmico, o objeto imediato, o interpretante imediato, o interpretante dinâmico e o interpretante final. Mais do que fazer uma análise exaustiva de cada um desses elementos, a proposta permite superar a dicotomia entre emissor e receptor, pois, como já destacamos, a semiose ou ação do signo se dá em um contínuo e a significação não depende apenas das posições lógicas do emissor e do receptor. Assim, cada perfil será abordado a partir das possíveis intencionalidades e relações que estabelecem entre a ideia que se deseja comunicar e os possíveis intérpretes.

Recordamos que a semiose também depende do contexto e da "experiência colateral" dos sujeitos envolvidos no fenômeno. Por isso, nossa análise considera alguns aspectos da atividade de coach de carreira no Brasil e suas relações com o atual contexto socioeconômico, buscando traçar como esses aspectos se relacionam com as autorrepresentações. Nesse sentido, realizamos, ao longo de 2019, uma observação não sistematizada, de caráter exploratório, dos sites oficiais e dos perfis no Instagram de cinco instituições que oferecem formação em coaching, além de acompanhar os perfis profissionais dos fundadores dessas organizações e reportagens sobre o tema, com a finalidade de verificar os tipos de conteúdos e assuntos relacionados à atuação de coaches.

Adicionalmente, assinalamos que o Sinequismo e o Tiquismo nos ajudam a observar o dinamismo das trocas comunicacionais nas redes sociais digitais e das autorrepresentações que emergem nesses espaços. Com esses conceitos, buscamos identificar a tendência à aquisição de hábitos na semiose engendrada no Instagram, considerando os elementos de acaso inerentes a esse processo.

Registramos aqui que, no início da pesquisa, avaliamos a possibilidade de realizar entrevistas em profundidade e grupos focais com coaches de carreira e, por conta disso, submetemos o projeto à Plataforma Brasil com o objetivo de adequá-lo aos parâmetros éticos necessários para pesquisas com seres humanos. Embora a proposta tenha obtido 
parecer favorável, por meio de avaliação do Comitê de Ética em Pesquisa Envolvendo Seres Humanos da Escola de Artes, Ciências e Humanidades da USP, entendemos, com o avanço da dissertação, que essas ferramentas não trariam as respostas buscadas em nossa investigação. Por esse motivo, elas foram descartadas.

Destacamos que é impossível investigar as autorrepresentações no ambiente digital de modo dissociado da plataforma na qual elas se inserem. Nesse sentido, a análise dos perfis de coaches de carreira foi desenvolvida concomitantemente à investigação do funcionamento e das características do Instagram, bem como do contexto socioeconômico e de particularidades do universo dos coaches de carreira. Por questões didáticas, optamos por apresentar uma discussão sobre o Instagram no capítulo anterior, embora tais considerações façam parte da análise dos perfis.

Assim, apresentamos a seguir os critérios para a escolha dos perfis analisados. $\mathrm{Na}$ seção seguinte, realizamos uma breve apresentação do universo relacionado à atividade de coaching, de modo a conseguir subsídios sobre os repertórios e a experiência colateral envolvida nos processos de autorrepresentação de coaches de carreira. Por fím, apresentamos a descrição dos dados e a análise dos perfis selecionados.

\subsection{Amostragem: seleção de perfis}

A escolha da amostra a ser analisada partiu de uma busca manual de perfis na ferramenta de pesquisa do Instagram, em abril de 2019, por meio da conta pessoal da pesquisadora nesta rede. Para isso, usamos a seção Explorar do Instagram e pesquisamos as palavras-chave "coach de carreira" e "professional coach", visualizando os resultados por meio da aba contas. ${ }^{71}$ Em seguida, selecionamos os perfis profissionais (com dados abertos) que apresentavam a palavra-chave "coach de carreira" no nome, e/ou na descrição da biografia, e/ou no nome de usuário.

Assim, organizamos uma lista com 139 perfis e passamos a acompanhar as atividades de alguns deles, sem a pretensão, contudo, de analisar todos os perfis listados. Ou seja, realizamos uma observação de caráter exploratório, embora já estivéssemos acompanhando outros perfis de profissionais de coaching desde fevereiro de 2019. Nessa

\footnotetext{
${ }^{71}$ Pontuamos que a busca manual no Instagram não é capaz de exibir todos os resultados possíveis de perfis de coaches de carreira. Além disso, devido a mecanismos de personalização, os resultados obtidos na busca podem estar alinhados à valoração que a rede faz sobre as supostas preferências relacionadas ao perfil usado na busca. Ou seja, não é possível conhecer a totalidade de perfis de coaches de carreira dentro do Instagram e, mesmo que fosse possível, o resultado seria um número fadado à rápida desatualização, uma vez que perfis podem ser criados, modificados ou excluídos em poucos minutos.
} 
primeira coleta, $70 \%$ dos perfis correspondiam ao gênero feminino, $29 \%$ ao gênero masculino e em $1 \%$ dos casos não havia identificação. Apesar dessa primeira exploração dos perfis, ainda tínhamos dúvidas sobre quais deles deveriam ser analisados em profundidade. Nossa preocupação era evitar uma escolha subjetiva que comprometesse os resultados da pesquisa.

A partir da perspectiva semiótica, podemos afirmar que a comunicação e a geração de significados só se realizam quando o signo, determinado pelo objeto, gera interpretantes. É preciso, portanto, que haja atualização do signo, de acordo com a experiência colateral dos possíveis intérpretes e os elementos inerentes ao signo que possibilitam sua interpretabilidade. Por conseguinte, do ponto de vista da semiose relacionada à comunicação humana, embora as possibilidades de interpretação estejam contidas no signo, a efetivação dessa interpretação está relacionada às vivências dos sujeitos envolvidos no processo e à relação. Conforme pontua Iasbeck (2017),

Temos de considerar [...] que é ao receptor que o emissor, suas intenções e estratégias se dirigem. É para o outro e com o outro que o processo faz sentido. Cabe ao emissor marcar o encontro, provocar a relação. O sentido da comunicação não pode estar, pois, atrelado apenas às competências do emissor, da mesma forma que não pode ficar circunscrito às mazelas da recepção. Só há sentido na comunicação [...] quando surge a relação. (IASBECK, 2017, p. 201, itálico do autor).

Assim, entendemos que a análise dos perfis de coaches de carreira, considerados aqui como conjuntos de signos em relação, precisaria levar em consideração os possíveis interpretantes que esses perfis podem gerar. Apesar da impossibilidade de avaliar todos os interpretantes nesta pesquisa, essa observação ajudou a orientar nossas decisões sobre o corpus.

Com base no entendimento sobre a necessidade de ter critérios gerais capazes de apontar os perfis de coaches de carreira a serem analisados, firmamos uma parceria sem fins lucrativos com a empresa Airfluencers (Airstrip), que possui uma ferramenta de busca de perfis com dados abertos em redes sociais denominada Airsearch. ${ }^{72}$ Embora a ferramenta tenha seus próprios critérios, que podem se refletir em possíveis vieses, acreditamos que a seleção dos perfis com o apoio deste mecanismo possibilitou uma certa

\footnotetext{
${ }^{72}$ A Airfluencers é uma plataforma brasileira dedicada ao gerenciamento de marketing com os chamados influenciadores. É voltada especialmente para agências e marcas, embora também ofereça serviços aos influenciadores. Mais informações disponíveis em: <https://airfluencers.com/>. Acesso em: 10 mar. 2019.
} 
uniformidade na decisão. De maneira simplificada, a ferramenta Airsearch funciona como um site de buscas, em que é possível selecionar perfis públicos nas seguintes redes sociais: Instagram, Facebook, Twitter, Youtube e Pinterest. Para selecionar os perfis, a ferramenta oferece filtros, o que possibilita fazer levantamentos a partir de palavras-chave, rede social usada, descrição da biografia, localização, temas mais abordados pelos perfis e marcas citadas, conforme pode ser observado em sua interface:

Figura 17 - interface da ferramenta de busca Airsearch, da empresa Airfluencers.

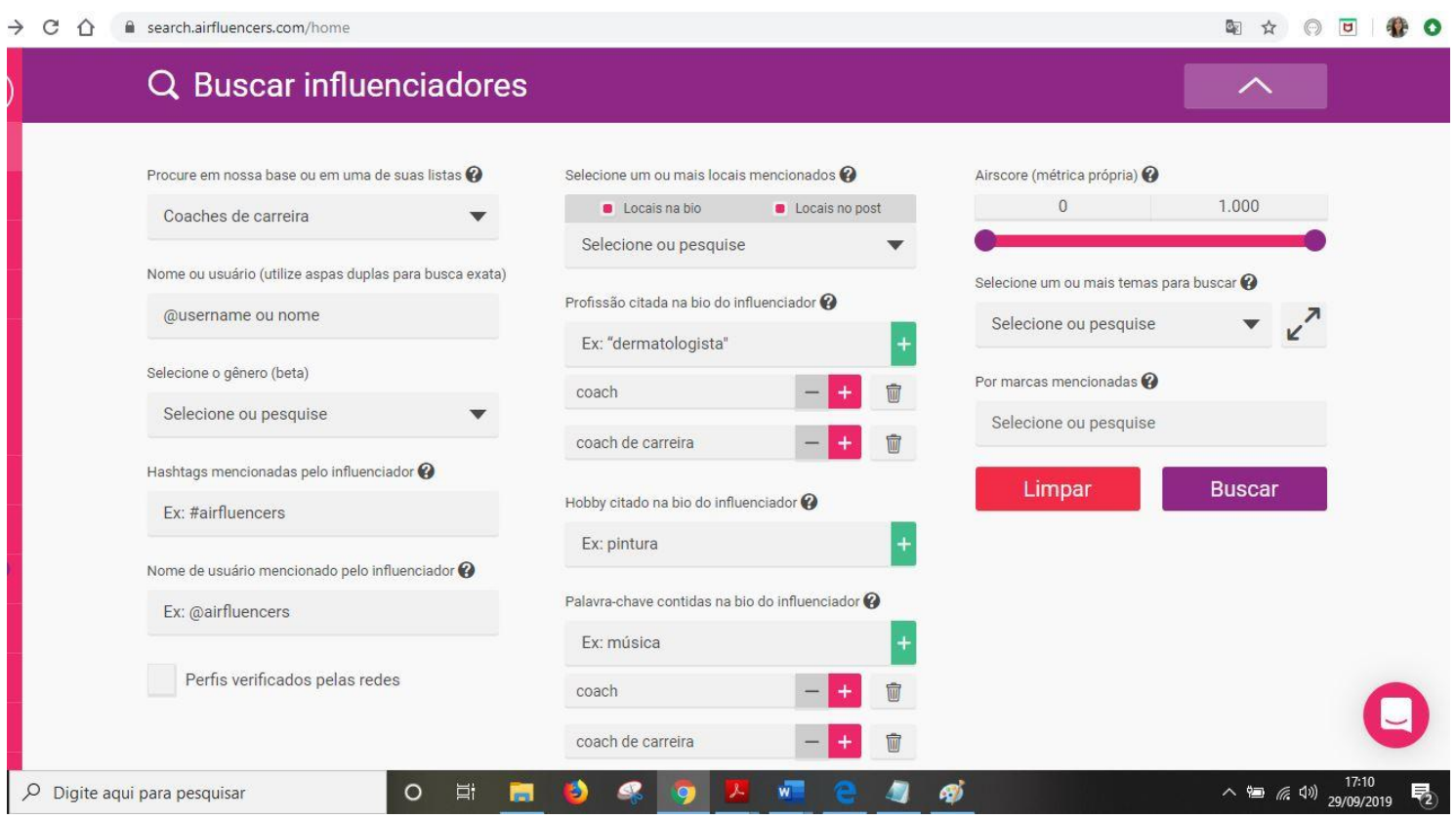

Fonte: print screen da ferramenta, cedida pela empresa para a pesquisa.

A busca no Airsearch leva em consideração apenas perfis que tenham sido incluídos previamente na base da plataforma, ação que pode ser realizada por qualquer usuário com uma conta cadastrada. O levantamento considera as postagens e atividades dos perfis nos 90 dias anteriores à busca.

Nesse sentido, adicionamos à Airsearch os 139 perfis previamente selecionados em nossa busca manual, incluindo os links do Instagram de cada um deles. Em seguida, fizemos a busca, em 4 de maio de 2019, usando os filtros "profissão citada na bio do influenciador" e "palavra-chave contida na bio do influenciador", preenchendo-os com a palavra-chave "coach de carreira". Após a definição dos critérios de busca, a ferramenta oferece uma lista de resultados, que pode ser visualizada em ordem crescente ou decrescente de: tamanho de base de seguidores (número de seguidores, fãs ou inscritos); relevância (relevância de acordo com os filtros usados na pesquisa); ordem alfabética (de 
$\mathrm{A}$ a $\mathrm{Z}$, ou de $\mathrm{Z}$ a $\mathrm{A}$ ); frequência de postagens (maior ou menor frequência de postagem nos últimos 90 dias); e Airfluencers Score ou Airscore (métrica própria que avalia o engajamento de um perfil, considerando o tamanho de base, a quantidade de postagens e a qualidade das interações recebidas, entre curtidas, comentários e compartilhamentos; quanto maior o engajamento, mais destaque o perfil pode ter na rede e entre suas conexões).

Decidimos ordenar o resultado, em ordem decrescente, de acordo com a métrica Airscore, pois entendemos que ela considera as interações realizadas nos perfis, e, nesse sentido, captaria, ainda que de forma limitada e sujeita a erros, a atualização de alguns signos dos perfis. A Airfluencers esclarece em seu blog como avalia as interações:

Acreditamos que cada tipo de interação deve ter um "peso". Receber uma curtida em uma foto é muito mais fácil do que receber um comentário ou um compartilhamento, certo? Como estas interações são mais "difíceis" de conseguir, sua qualidade é diferente e seu peso é maior. Com isso, chegamos na nota de Score do influenciador. Então, mesmo que certo influenciador tenha uma maior quantidade de interação, outro influenciador pode ter melhor qualidade de interações e assim ter o maior score. (AIRFLUENCERS, 2019).

A partir do resultado ordenado por meio da métrica Airscore, excluímos os perfis que não apresentavam a palavra-chave "coach de carreira" no nome, no nome de usuário e/ou na descrição da biografia. Em seguida, selecionamos seis perfis dentre os 20 melhor ranqueados, levando em consideração aqueles que haviam feito mais postagens no feed por semana, ou seja, os que apresentavam, no momento da coleta e nos 90 dias anteriores (entre o início de fevereiro e o início de maio de 2019), uma frequência maior de postagens, pois nosso objetivo era avaliar perfis que tivessem mais ações relacionadas à autorrepresentação. Após a coleta, continuamos acompanhando os perfis esporadicamente até novembro de 2019. Elucidamos que esse recorte não é capaz de abarcar toda a complexidade do fenômeno e, em se tratando de autorrepresentações criadas em uma rede social digital, elas estão sujeitas a transformações constantes. Por conseguinte, as análises apresentadas aqui devem ser consideradas principalmente como uma ilustração das operações semióticas relacionadas ao fenômeno da autorrepresentação em ambientes digitais.

Outrossim, a análise tem caráter estritamente acadêmico, de acordo com os objetivos propostos nesta dissertação. Foram selecionados apenas perfis públicos, ou seja, com dados abertos por opção de seus usuários; apesar disso, todos os dados foram 
anonimizados para preservar as identidades os donos dos perfis. Acrescentamos, ainda, que esta análise não tem como objetivo avaliar ou julgar o trabalho de coaches e/ou a atividade de coaching, mas apenas exemplificar e discutir, a partir do recorte proposto, os mecanismos semióticos envolvidos nos processos de autorrepresentação.

A partir deste recorte, decidimos analisar os seguintes elementos de cada perfil: foto de perfil; nome de usuário; nome; categoria (selecionada pelo dono do perfil); biografia; e destaques dos stories (se houver). Em relação aos destaques, não faremos a análise exaustiva desses elementos, mas pontuaremos o que os sujeitos decidiram destacar em suas autorrepresentações. Além disso, escolhemos seis fotos publicadas no feed de cada perfil (considerando os 90 dias anteriores à data da busca) que obtiveram mais curtidas e comentários, uma vez que esse seria um indício de que o signo foi capaz de provocar interpretantes dinâmicos. Ponderamos, entretanto, que não analisamos as interações geradas por cada postagem, devido às limitações e aos objetivos desta pesquisa. Tampouco consideramos vídeos e Stories em nossa análise, embora a observação exploratória desses elementos tenha contribuído para as considerações sobre o processo de autorrepresentação.

\subsection{Coaching e coaches de carreira: experiência colateral}

Para compreender a semiose engendrada nas autorrepresentações de coaches de carreira no Instagram, é preciso conhecer, ainda que de modo breve, o contexto em que esta atividade se insere no Brasil. Em outras palavras, é necessário identificar a experiência colateral daqueles que se autorrepresentam e dos que mantém conexões com perfis de coach.

Em primeiro lugar, cabe pontuar que a atividade de coach de carreira, assim como a atividade de coach, não é uma profissão regulamentada no Brasil. ${ }^{73}$ Entretanto, uma rápida busca no Google com a palavra coach traz entre os resultados pelo menos cinco instituições que oferecem "formação em coaching", com metodologias, nomenclaturas e cargas horárias variadas: Instituto Brasileiro de Coaching, Sociedade Latino Americana de Coaching, Sociedade Brasileira de Coaching, Febracis Coaching Integral Sistêmico, e Instituto Geronimo Theml de Coaching e Desenvolvimento Humano.

\footnotetext{
${ }^{73}$ Classificação Brasileira de Ocupações do Ministério do Trabalho. Disponível em: http://www.mtecbo.gov.br/cbosite/pages/regulamentacao.jsf\#j. Acesso em: 10 fev. 2019.
} 
A partir das informações disponíveis nos sites das cinco instituições supracitadas, pode-se afirmar que a Febracis Coaching Integral Sistêmico é a mais antiga delas, tendo sido fundada em 1998 por Paulo Vieira (FEBRACIS, 2019b). A Sociedade Brasileira de Coaching foi fundada em 1999 por Villela da Matta e Flora Victoria e afirma ter como missão "promover a evolução e a maximização do potencial humano por meio de soluções exclusivas de coaching e treinamentos de alta performance, gerando aumento de resultados para pessoas, times e empresas." (SBC, 2019a). Por sua vez, o Instituto Brasileiro de Coaching foi fundado em 2007 por José Roberto Marques e, de acordo com o site oficial, "considera o Coaching como um Estilo de Vida, em que se prima pelo desenvolvimento do ser humano como um todo." (IBC, 2019a).

Não há informações sobre a data de fundação da Sociedade Latino Americana de Coaching, cujo presidente é Sulivan França. Apesar disso, o site informe que em 2002 a instituição tornou-se credenciada e reconhecida pela International Association of Coaching Institute, "órgão que regula, testa, valida e regulamenta o uso e a prática de coaching em toda a Europa." (SLAC, 2019a). Já o site do Instituto Geronimo Theml de Coaching e Desenvolvimento Humano informa que seu fundador, Geronimo Theml, é professor e treinador há mais de 19 anos. (IGT, 2019).

Grosso modo, ainda segundo essas instituições, o coaching (treinamento, em inglês) é uma assessoria que usa métodos, treinamentos e técnicas para que indivíduos e empresas alcancem metas pessoais e profissionais. Nesse contexto, coach (treinador, em inglês) é a pessoa que realiza esses treinamentos e orientações. De acordo com o Instituto Brasileiro de Coaching, coaching é "um processo, uma metodologia, um conjunto de competências e habilidades que podem ser aprendidas e desenvolvidas por absolutamente qualquer pessoa pra alcançar um objetivo na vida pessoal ou profissional, até 20 vezes mais rápido, comprovadamente." (IBC, 2019b).

A Sociedade Latinoamericana de Coaching afirma em seu site que o coaching oferece técnicas e ferramentas capazes de ajudar o indivíduo "na definição de planejamento de negócios ou carreira, na integração dos negócios e vida pessoal em busca do equilíbrio e na potencialização de desempenho no trabalho" (SLAC, 2019ab). Já a definição dada à atividade pela Sociedade Brasileira de Coaching carrega um apelo mais explícito à ciência:

O coaching é uma assessoria pessoal e profissional que utiliza procedimentos orientados, cientificamente validados, para que indivíduos, times e empresas alcancem resultados superiores e 
positivos. Com ele, é possível entender como nós pensamos, sentimos, reagimos, aprendemos, mudamos e evoluímos. (SBC, 2019b).

A ciência também faz parte da definição de coaching da Febracis: "Coaching é uma metodologia, uma ferramenta, um misto entre arte e ciência, que promove o desempenho individual e coletivo, tornando o ser humano cada vez melhor, atingindo seus objetivos e resolvendo seus problemas." (FEBRACIS, 2019a). O Instituto Geronimo Theml de Coaching e Desenvolvimento Humano destaca que o coaching está relacionado ao aumento da produtividade e da capacidade de planejamento, o que traria “potencialização dos seus resultados pessoais e profissionais" (IGT, 2019).

Encontramos ainda algumas descrições mais específicas sobre a atividade de coach de carreira, como a fornecida pela Sociedade Latinoamericana de Coaching: "Um coach de carreira pode ajudar os clientes a encontrar a paixão que perderam em suas carreiras ou a encontrar a coragem para avançar para uma nova carreira, o que chamamos de transição.” (SLAC, 2019c). A Sociedade Brasileira de Coaching informa que o coaching de carreira seria uma espécie de especialização do coaching que "habilita a atuar com todas as fases do desenvolvimento de uma carreira: do ingresso no mercado de trabalho à aposentadoria" (SBC, 2019c).

As definições de coaching remetem à proposta de desenvolvimento humano e de união entre aspectos da vida pessoal e profissional, por meio da qual os sujeitos estariam aptos a conquistar seus objetivos. Há ainda um apelo às emoções, ao autodesenvolvimento e à realização de sonhos, como no destaque do site da Sociedade Latino Americana de Coaching: "descubra como transformar sonhos em realidade utilizando a metodologia coaching na sua vida!" (SLAC, 2019b). De modo semelhante, a SBCoaching apela às emoções, em página do site dedicada à promoção de cursos de coach de carreira: "quer se tornar um coach de carreira, duplicar sua clientela e obter ganhos extraordinários? você está a um passo de tornar o seu desejo realidade!" (SBC, 2019c). Outrossim, observamos certo empenho no sentido de validar a atividade, por meio de palavras e expressões como "ciência", "metodologia", “comprovadamente", "cientificamente validados".

Ainda sobre as atividades de coaching, acrescentamos que algumas organizações fornecem credenciais para aqueles que desejam atuar nessa área e reúnem membros para eventos internacionais, em atuação semelhante a entidades de classe. Um dos exemplos é a International Coach Federation, criada em 1995 nos Estados Unidos e que possui sede 
em São Paulo, além de mais oito estados e o Distrito Federal. A instituição afirma ter mais de 27.000 membros em 140 países. (ICF, 2019). O levantamento ICF Global Coaching Study, conduzido pela PricewaterhouseCoopers (PwC) e publicado em 2012, informa que existem 47.500 coaches profissionais no mundo, sendo 41.300 ativos. $^{74}$

No Brasil, a Sociedade Latinoamericana de Coaching afirma ter formado mais de 37.000 coaches; entre os que concluíram o curso de formação em coaching, 22,3\% seriam psicólogos, 16,7\% administradores, 13,5\% profissionais de educação física, 9,5\% publicitários, 7,5\% médicos, 6,9\% economistas e 6,7\% jornalistas. ${ }^{75}$ Embora não seja possível saber com precisão o número de pessoas que atuam como coaches no Brasil, essa atividade possui certo destaque no cenário nacional. Em 2018, o ranking geral de livros mais vendidos no País do Publishnews aponta que o livro O Poder da Ação, escrito pelo coach Paulo Vieira e publicado pela editora Gente, ficou na sétima posição entre 20 obras, com 141.681 exemplares vendidos; outro livro de mesmo autor e editora, O poder da autorresponsabilidade, ficou em décimo lugar, com 119.337 exemplares vendidos. ${ }^{76} \mathrm{O}$ livro O Poder da Ação também esteve entre os mais vendidos nos anos em 2019 (117.315 exemplares), 2017 (130.909 exemplares) e 2016 (98.298 exemplares). Já o livro Produtividade para quem quer tempo, do palestrante Geronimo Theml, ficou em sexto lugar no ranking de livros de negócios mais vendidos em 2016, com 26.336 exemplares. Além de fundadores de instituições que oferecem cursos de coaching, os dois autores têm perfis ativos em redes sociais digitais e perfis verificados Instagram. ${ }^{77}$ Paulo Vieira, por exemplo, tem mais de um milhão de seguidores no Instagram, enquanto Geronimo Theml tem mais de 600 mil seguidores na mesma rede.

Em 2018, a atividade de coaching foi alvo de uma polêmica após a rede Globo levar ao ar uma ação publicitária do Instituto Brasileiro de Coaching durante uma cena da novela "O outro lado do paraíso", exibida no horário das nove da noite, tradicionalmente o de maior audiência. Na obra de ficção, uma das personagens que sofreu abuso sexual busca a ajuda de uma coach para superar o trauma psicológico, fato

\footnotetext{
${ }^{74}$ Disponível em: < https://coachfederation.org/app/uploads/2017/12/ICF-Exec-Summary-FINALPortuguese.pdf $>$. Acesso em: 19 mai. 2019.

${ }^{75}$ Disponível em: < https://www.slacoaching.com.br/institucional/nossa-historia $>$ e

$<$ https://www.slacoaching.com.br/numeros-do-mercado-de-coaching > . Acesso em: 19 mai. 2019.

${ }^{76}$ Disponível em: < https://www.publishnews.com.br/ranking/anual/>. Acesso em: 10 mar 2019.

${ }^{77} \mathrm{O}$ Instagram disponibiliza um selo azul de verificação a algumas contas para atestar que elas são verdadeiras e se referem a uma figura pública, celebridade, marca ou entidade notável. Mais informações em: <https://about.instagram.com/blog/>. Acesso em: 20 mar. 2020.
} 
que motivou críticas do Conselho Federal de Psicologia, manifestações de coaches e uma denúncia ao Conselho Nacional de Autorregulamentação Publicitária. ${ }^{78}$

A partir de 12 de maio de 2019, tramitou no Senado uma proposta de iniciativa popular pela criminalização da profissão de coach. Apresentada em 15 de abril daquele ano ao Portal e-Cidadania, a proposta de um morador de Sergipe recebeu mais de 20 mil apoios e foi transformada na sugestão legislativa 26/2019, sendo posteriormente encaminhada à Comissão de Direitos Humanos e Legislação Participativa, com relatoria do senador Paulo Paim, do Partido dos Trabalhadores do Rio Grande do Sul. ${ }^{79}$ Pontuamos aqui que a coleta dos perfis para nossa análise foi feita em 4 de maio de 2019, portanto, antes do início da discussão da proposta. Em março de 2020, o relatório do senado Paulo Paim propôs o arquivamento da sugestão alegando que, como a profissão de coach não é regulamentada, ela não pode ser criminalizada, com exceção de invasão do campo de atuação de outras profissões regulamentadas. ${ }^{80}$

A respeito dos assuntos e tipos de conteúdos encontrados nos sites e nas publicações dos perfis oficiais no Instagram das cinco instituições de coaching citadas acima, pontuamos a recorrência de temas como "felicidade", "sucesso", "resultados", "propósito", "realização de sonhos", "aumento de performance", "alta performance", "futuro", "alcance de metas", "metas", "mudança de vida" e "produtividade". Em relação à escolha das imagens, chama a atenção a repetição de fotos de pessoas com microfone nas mãos ou microfone de cabeça e grandes plateias, de pessoas com os braços estendidos em comemoração (alguns com punhos cerrados) e de indivíduos com os braços cruzados, em pose de liderança. Além disso, observa-se a presença de figuras que remetem a alvos, foguetes, livros, troféus e medalhas.

A atividade de coaching foi tema de reportagens em sites de notícias e revistas de negócios, algumas fruto de materiais de divulgação para a impressa. A revista Exame, por exemplo, publicou em março de 2019 conteúdo publicitário com o título "Coaching cresce mais de $300 \%$ no país, movimenta milhões e atrai profissionais que buscam se

\footnotetext{
${ }^{78}$ Informações disponíveis em: < https://www.gazetadopovo.com.br/viver-bem/saude-e-bem-estar/novelao-outro-lado-do-paraiso-incentiva-coaching-psicologos-criticam/> e

$<$ https://telepadi.folha.uol.com.br/merchandising-de-coaching-na-novela-das-9-da-globo-e-denunciadoao-conar/>. Acesso em: 10 mar 2019.

${ }^{79}$ Disponível em: < https:/www12.senado.leg.br/noticias/materias/2019/05/23/criminalizacao-ouregulamentacao-do-coaching-esta-em-discussao-no-senado $>$. Acesso em: 27 mai. 2019.

${ }^{80}$ Disponível em: $<$ https://www12.senado.leg.br/noticias/materias/2020/03/16/paim-propoearquivamento-de-sugestao-para-criminalizar-profissao-de-coach>. Acesso em: 3 mai. 2020.
} 
reinventar". ${ }^{81}$ Em setembro do mesmo ano, a revista Forbes publicou a reportagem "Tudo sobre coaching: como não errar na escolha de um bom profissional". ${ }^{82}$ Já o jornal Folha de S. Paulo discutiu a possível criminalização da profissão em reportagem publicada em junho, com o título "Coaching é crime? Entenda o que está por trás desse debate", que ouviu pessoas que atuam como coaches, pessoas que foram atendidas por coaches e um psicólogo. ${ }^{83}$

\subsection{Descrição dos dados}

Apresentamos nesta seção a descrição dos perfis selecionados, incluindo as postagens no feed com mais interações de cada um deles. Para preservar as identidades das pessoas envolvidas nessas autorrepresentações, seus nomes verdadeiros foram trocados e seus rostos, informações pessoais e nomes de usuário foram omitidos das imagens. Assim, os perfis selecionados de acordo com os critérios descritos anteriormente são:

\footnotetext{
${ }^{81}$ Disponível em: < https://exame.com/negocios/dino_old/coaching-cresce-mais-de-300-no-paismovimenta-milhoes-e-atrai-profissionais-que-buscam-se-reinventar/>. Acesso em: 28 mai. 2019. ${ }^{82}$ Disponível em: < https://forbes.com.br/carreira/2019/09/tudo-sobre-coaching-como-nao-errar-naescolha-de-um-bom-profissional/>. Acesso em: 30 set. 2019.

${ }^{83}$ Disponível em: < https:/www1.folha.uol.com.br/sobretudo/carreiras/2019/06/1988149-coaching-ecrime-entenda-o-que-esta-por-tras-desse-debate.shtml>. Acesso em: 30 set. 2019.
} 
Figura 18 - Perfis profissionais de Ana (à esquerda) e de Bia (à direita) no Instagram. ${ }^{84}$

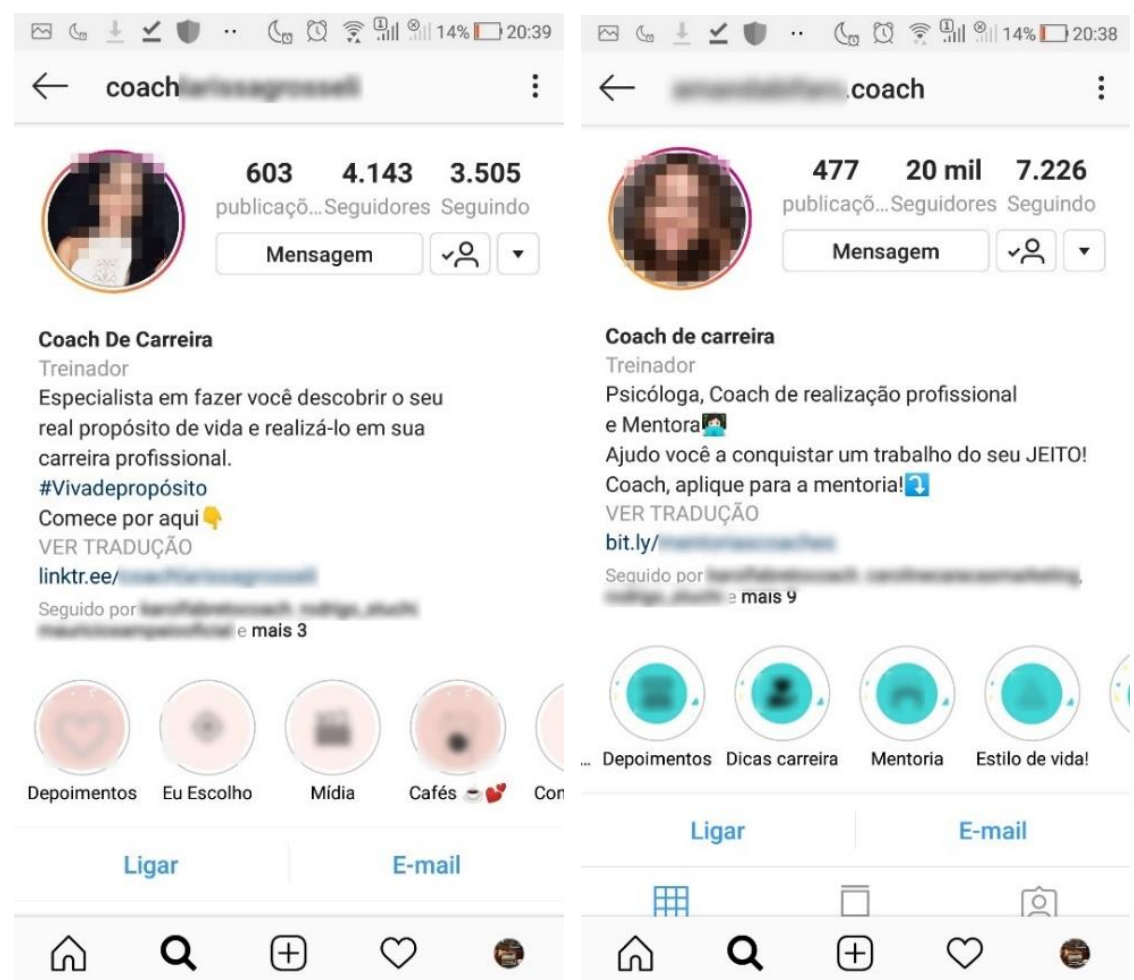

Fonte: print screen feito com smartphone a partir do perfil pessoal da pesquisadora.

Figura 19 - Perfis profissionais de Ciro (à esquerda) e Duda (à direita) no Instagram.

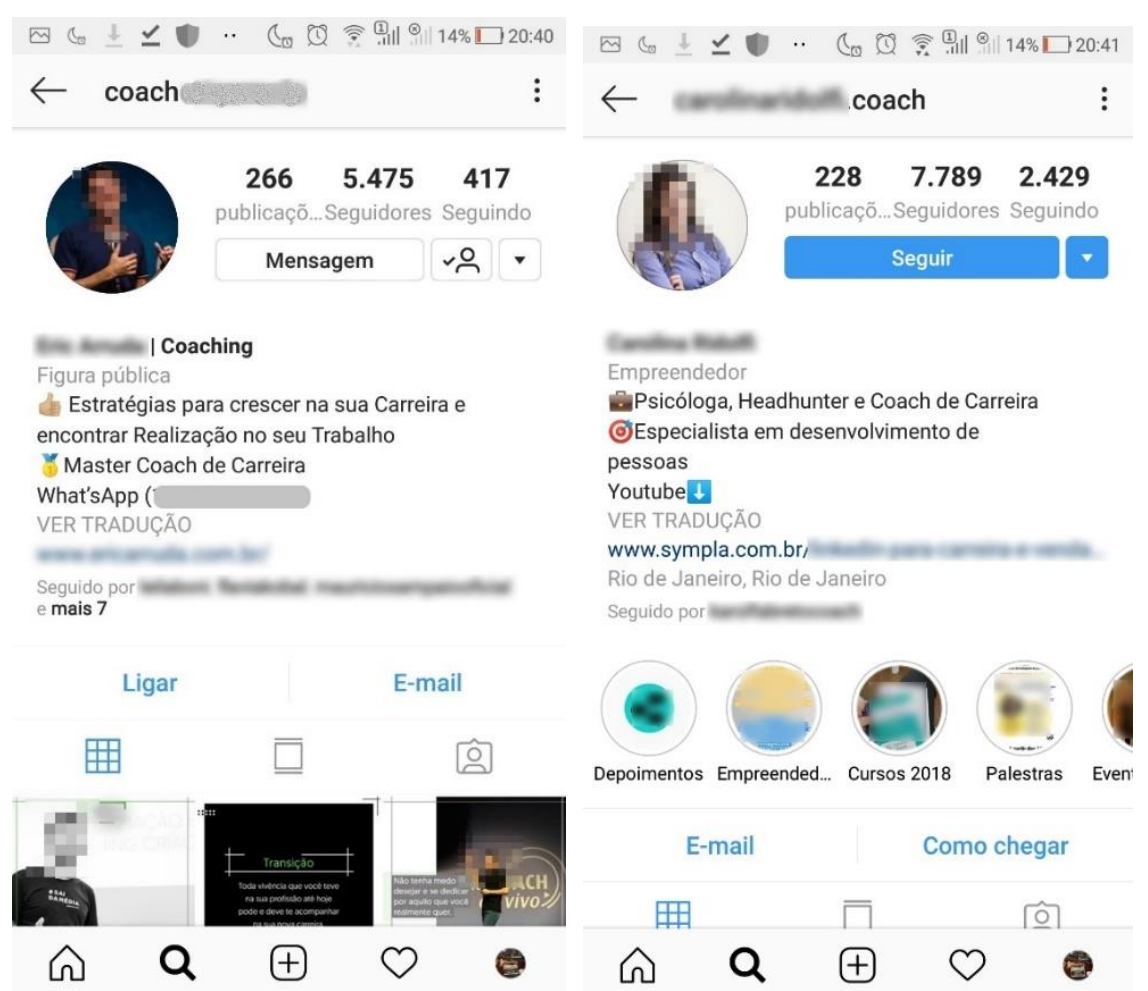

Fonte: print screen feito com smartphone a partir do perfil pessoal da pesquisadora.

${ }^{84}$ Os nomes dos sujeitos responsáveis pelos perfis analisados foram trocados para preservar suas identidades. 
Figura 20 - Perfis profissionais de Edi (à esquerda) e Fabi (à direita) no Instagram.

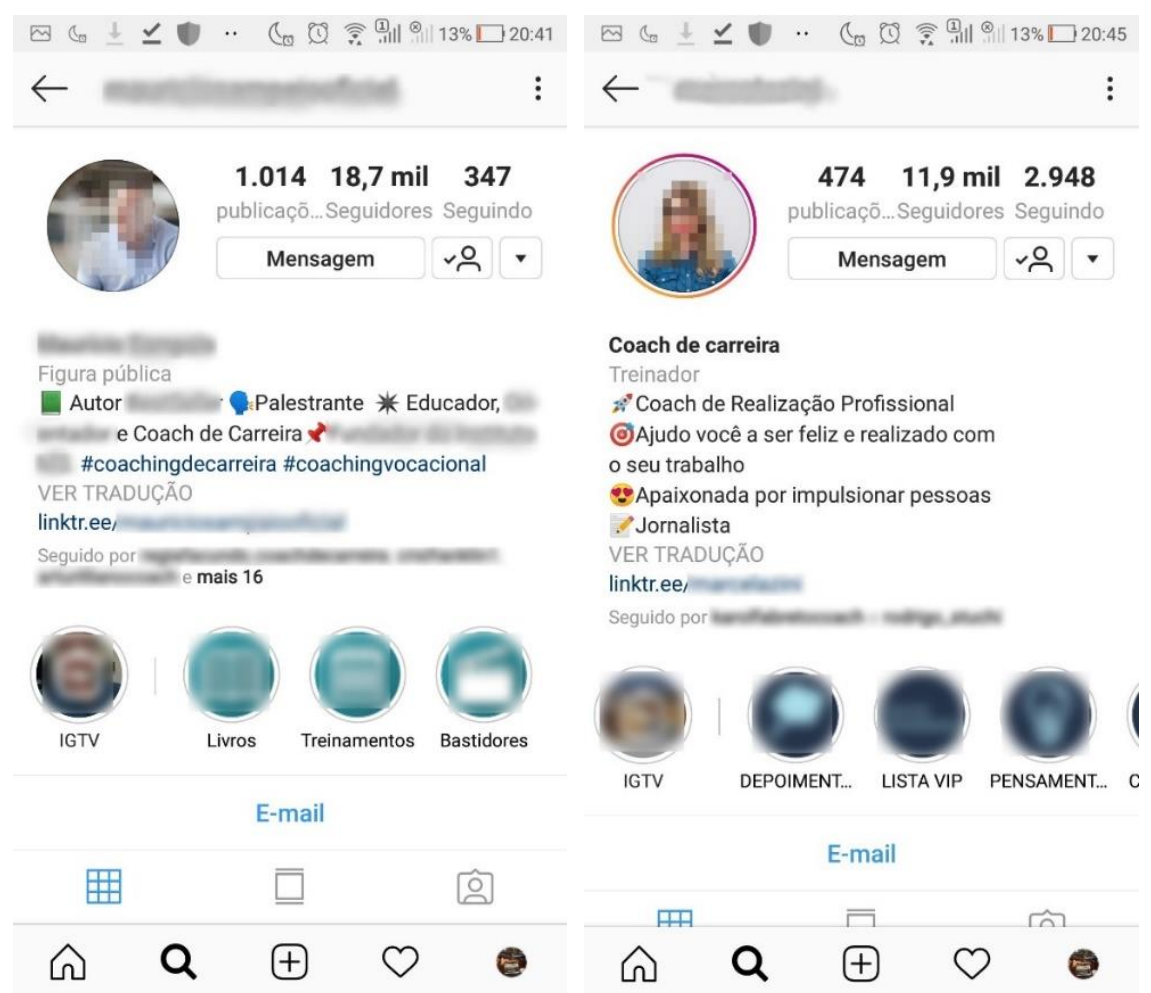

Fonte: print screen feito com smartphone a partir do perfil pessoal da pesquisadora.

Para uma visão geral dos perfis, realizamos a sistematização dos dados encontrados em cada uma das categorias analisadas (foto de perfil; nome de usuário; nome; categoria; biografia; e destaques do Stories) em uma tabela que pode ser consultada no anexo deste trabalho. Antes de iniciarmos nossa descrição, cabe pontuar que, nos casos em que a categoria "nome" ou "nome de usuário" estava composta por nome e sobrenome da pessoa autorrepresentada, como nos exemplos "Rebeka Figueiredo" e “@rebeka.figueiredo”, substituímos os nomes verdadeiros pelos modelos Nome Sobrenome e @nome.sobrenome. Iniciamos nossa descrição com os elementos dos perfis e, em seguida, passaremos aos aspectos do feed.

\subsubsection{Perfis}

No Instagram, como detalhamos no capítulo anterior, cada perfil deve ter um nome de usuário, escolhido pelo sujeito ao criar sua conta na rede. Nos casos analisados, quatro dos seis perfís incluíram a palavra coach no nome de usuário. Em relação à escolha do nome, metade dos sujeitos abdicaram de usar nessa seção o nome próprio ou apelido, 
como aconselha o Instagram, para usar a palavra-chave "coach de carreira". Os outros três optaram por colocar seus nomes e sobrenomes e um deles acrescentou, logo após seu nome, a palavra coaching, do seguinte modo: "Nome Sobrenome | Coaching". Ao abrir um perfil profissional, o usuário deve, obrigatoriamente, selecionar uma categoria dentre aquelas oferecidas pelo Instagram. Nos casos analisados, três dos perfis têm a categoria "Treinador"; dois deles optaram pela categoria "Figura Pública"; e um pela categoria "Empreendedor", conforme a tabela 1.

Tabela 1 - algumas informações dos perfis profissionais analisados.

\begin{tabular}{|l|l|l|l|}
\hline \multicolumn{1}{|c|}{ COACH } & \multicolumn{1}{|c|}{$\begin{array}{c}\text { NOME NO } \\
\text { INSTAGRAM }\end{array}$} & \multicolumn{1}{|c|}{ NOME DE USUÁRIO } & \multicolumn{1}{|c|}{ CATGORIA } \\
\hline Ana & Coach de Carreira & @coachnomesobrenome & Treinador \\
\hline Bia & Coach de Carreira & @nomesobrenome.coach & Treinador \\
\hline Ciro & $\begin{array}{l}\text { Nome Sobrenome } \\
\text { Coaching }\end{array}$ & @coachnomesobrenome & Figura pública \\
\hline Duda & Nome Sobrenome & @nomesobrenome.coach & Empreendedor \\
\hline Edi & Nome Sobrenome & $@$ nomesobrenomeoficial & Figura pública \\
\hline Fabi & Coach de Carreira & @nomesobrenome & Treinador \\
\hline
\end{tabular}

Legenda: Usamos "Nome Sobrenome" e "nomesobrenome" para indicar que o coach optou por inserir seu nome próprio nas categorias indicadas. Fonte: tabela elaborada pela pesquisadora.

Todos os perfis têm fotos nas quais os sujeitos aparecem com sorriso aberto, em primeiro plano, em postura que sugere intimidade e proximidade com o possível interlocutor. Apenas Ciro não olha para a câmera diretamente; ele está com um microfone de cabeça e suas mãos estão em movimento, como se fizesse uma apresentação ou palestra. As imagens têm boa qualidade, estão bem iluminadas e nítidas.

Com relação à biografia, que pode ter até 2.200 caracteres e incluir hashtags, emojis e menções a outros perfis, observamos que todos os perfis analisados têm pelo menos um emoji. Dois perfis possuem emojis de "seta apontando para baixo" (回) e um tem o emoji de "dorso da mão com dedo indicador apontando para baixo" (ఫ) ; nos três casos, eles apontam para um hiperlink. O emoji "no alvo" (ㅈ) está presente em dois perfis.

Ainda na biografia, quatro perfis apresentam o verbo "realizar" e/ou o substantivo "realização", relacionados à realização profissional ou na carreira: os perfis de Ana, Bia, Ciro e Fabi. Três perfis usam o pronome "você" na biografia, em textos com linguagem 
informal que se dirigem diretamente ao leitor. No perfil de Ana, encontramos a frase “Especialista em fazer você descobrir o seu real propósito de vida [...]”. O perfil de Bia apresenta o seguinte trecho: "Ajudo você a conquistar um trabalho do seu JEITO!". O perfil de Fabi traz uma afirmação semelhante ao de Bia: "Ajudo você a ser feliz e realizado com o seu trabalho." A palavra "carreira" aparece na biografia de quatro perfis (Ana, Ciro, Duda, Edi) e a palavra "trabalho" aparece em três perfis (Bia, Ciro e Fabi).

Além de se apresentarem como coaches de carreira, três perfis trazem atividades regulamentadas pela Classificação Brasileira de Ocupações do Ministério do Trabalho: Bia e Duda se apresentam como "psicóloga"; e Fabi se apresenta como "jornalista". Edi afirma, em sua biografia, que é "educador" sem, contudo, incluir credenciais de instituição de ensino reconhecida pelo Ministério da Educação. A palavra "especialista" aparece em duas biografias, embora em nenhum dos casos esteja relacionada a um curso reconhecido pelo Ministério da Educação: no perfil de Ana há a informação "Especialista em fazer você descobrir o seu real propósito de vida", enquanto o perfil de Duda traz o seguinte trecho: "Especialista em desenvolvimento de pessoas".

Dois perfis possuem hashtags: no caso de Edi, a biografia traz as hashtags “\#coachingdecarreira" e "\#coachingvocacional"; Ana usou a hashtag “\#Vivadepropósito". Nenhuma biografia menciona outro perfil. Apenas o perfil de Duda apresenta localização (Rio de Janeiro).

Todos os perfis têm endereços eletrônicos; três deles usaram o recurso árvore de links, que permite reunir, em apenas um link, caminhos para distintas páginas. No caso do perfil de Ana, por exemplo, o recurso foi usado para reunir seis links: um direcionado à playlist no Spotify; outro para o canal dela no YouTube; o terceiro para um link de venda de um planner; o quarto que direciona a um formulário do Google; o quinto com um link para o WhatsApp; e o sexto para o agendamento de um serviço oferecido por Ana. Já a árvore de links do perfil de Fabi tem um atalho para inscrição em uma lista de transmissão de conteúdos no WhatsApp; outro link que direciona a um formulário para agendamento de atendimento; e um terceiro link que direciona o usuário para depoimentos de clientes de Fabi. 
Figura 21 - árvore de links disponíveis nos perfís de Ana (à esq.) e de Fabi (à dir.).

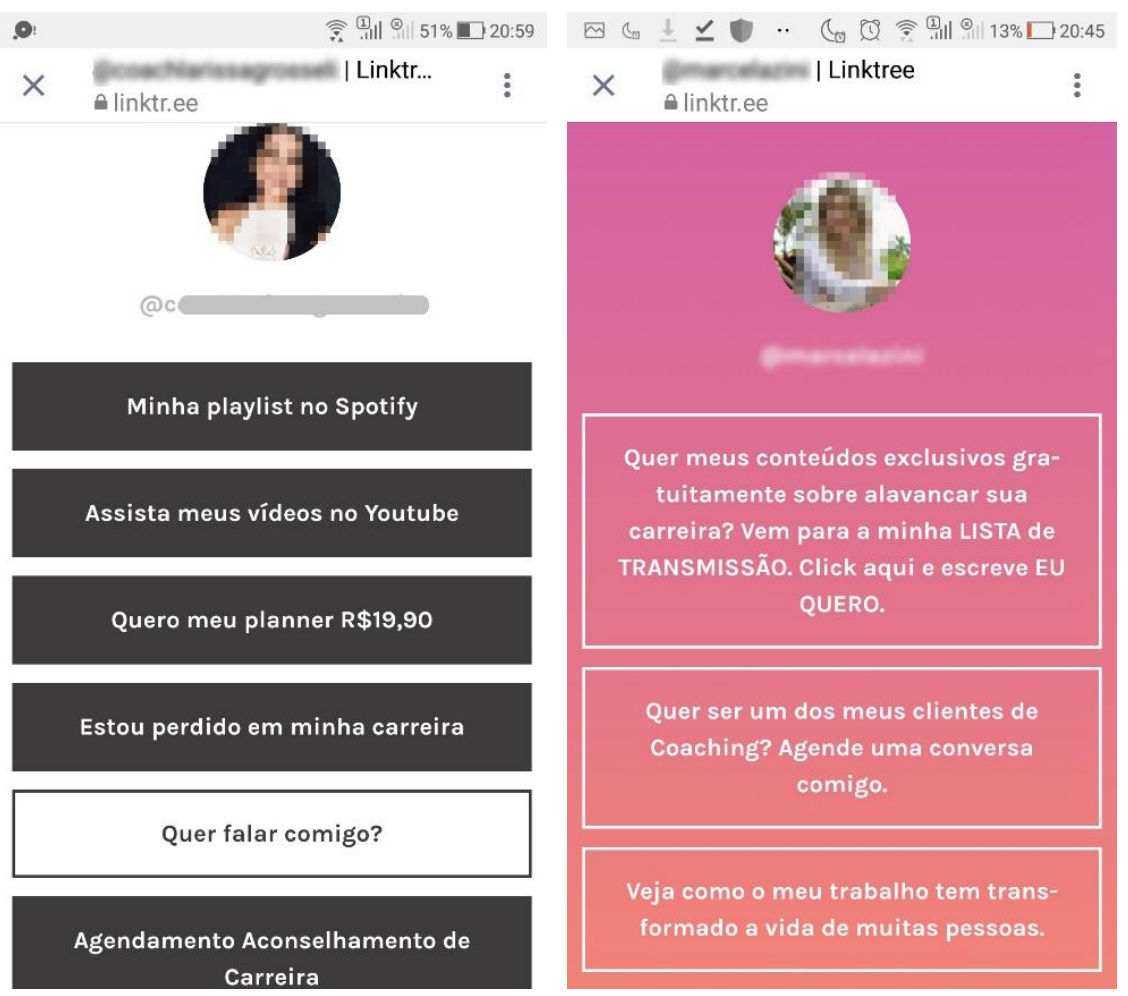

Fonte: print screen feito com smartphone a partir do perfil pessoal da pesquisadora.

Em relação aos destaques, apenas o perfil de Ciro não traz essa seção. Como explicamos no capítulo anterior, os destaques são uma coleção organizada pelo dono do perfil a partir de suas publicações nos Stories, ou seja, ao criar um destaque e selecionar certos conteúdos, o dono do perfil decide tornar perenes algumas publicações criadas inicialmente para durar apenas 24 horas. Quatro perfis (Ana, Bia, Duda, Fabi) apresentam destaques dedicados a depoimentos, que reúnem relatos de clientes e ex-clientes dos coaches autorrepresentados em formato de vídeo, foto com texto escrito, e texto escrito. O perfil de Edi traz o destaque "bastidores", com fotos e vídeos de suas palestras. Duda apresenta dois destaques relacionados à sua formação, "palestras" e "cursos", nos quais reuniu conteúdos sobre palestras e cursos em que ela participou como ouvinte e/ou aluna.

Três perfis (Bia, Edi, Fabi) trazem destaques dedicados exclusivamente às dicas de livros. Estilo de vida é outro tema recorrente nos destaques. Embora apenas o perfil de Bia apresente um destaque chamado "estilo de vida", outros coaches também decidiram destacar conteúdos que mostram seus hábitos, comportamentos e padrões de consumo. Nesse sentido, o destaque de livros também é uma forma de revelar certos gostos pessoais. O perfil de Ana, por exemplo, traz o destaque "cafés", que reúne fotos de Ana em diferentes cafeterias. Duda mostra os bastidores de sua rotina no trabalho, em imagens 
nas quais aparece trabalhando com notebook, no destaque denominado "Empreendedorismo".

\subsubsection{Publicações de Ana}

Entre fevereiro e maio de 2019, período escolhido para a análise dos perfis, as publicações no feed de Ana concentraram-se principalmente em selfies, registros de seu dia a dia e fotos com outros profissionais da área de coaching, especialmente aqueles que são figuras públicas. Destacaram-se ainda fotos em que Ana aparece segurando um microfone, em eventos promovidos por ela, e em outros nos quais ela parece ser convidada, dentre outros palestrantes. Ana também postou fotos em que está em meio à natureza, cercada por árvores ou sentada em frente a um lago, em pose de meditação.

Entre os registros de sua rotina, chamam a atenção fotos em que aparecem cafés e taças de vinho e espumante. Há, por exemplo, uma imagem em que Ana está trabalhando com um notebook em um lugar aberto, arborizado, com chão de areia, ao lado de uma taça de vinho. Ana aparece em trajes mais informais, sem o rigor do mundo corporativo.

Nas legendas que acompanham as postagens observam-se temas como realização de sonhos, viver com propósito, superação de obstáculos na vida, autoconhecimento, superação de inseguranças e medos e gratidão aos que a ajudaram em sua trajetória como coach.

As seis postagens que obtiveram mais curtidas e comentários no período trazem relatos de experiências da vida de Ana, com textos em primeira pessoa, seguidos de lições sobre como lidar com pressões e vencer limitações pessoais. As legendas das postagens são finalizadas com perguntas ao possível interlocutor sobre o tema proposto, como nos exemplos: "E você? Tem ligado ou mandando mensagem pra quem tem saudades? Perguntado se essa pessoa está bem?”; “Quem você olha com um olhar de admiração?”, e "Quem são as pessoas que não te deixam cair?".

Em geral, os textos estão focados em relatar sentimentos, mas não há, por exemplo, a descrição ou citação de situações diretamente relacionadas a carreira ou a experiências de trabalho. Fala-se em realização de sonhos, mas o sonho não é citado ou descrito, ou seja, não se sabe exatamente que sonho foi realizado, embora seja possível inferir, a partir da legenda, que o sonho realizado é a superação de medos, crenças antigas e inseguranças pessoais. 
Dentre as hashtags escolhidas nas seis postagens com mais interações, chama a atenção a falta de palavras-chave como "carreira", "emprego" e "trabalho", embora Ana se apresente como coach de carreira. Em apenas uma das seis postagens com mais interações ela usou uma hashtag mais relacionada ao mundo profissional: "\#negocios". As hashtags mais usadas em seu perfil são: "\#coaching", "\#proposito" e "\#euvivodeproposito". Não houve marcação de localização em nenhuma das seis postagens.

Em metade das postagens com mais interações, Ana menciona o perfil de uma figura pública bastante conhecida na área de coaching (figura 22, à esquerda). Nas três respectivas legendas, ela faz agradecimentos à pessoa citada pelos ensinamentos fornecidos. Em duas das três postagens, a pessoa mencionada aparece na foto; na terceira, Ana parece sozinha, segurando um microfone.

Figura 22 - fotografias do perfil de Ana no Instagram.

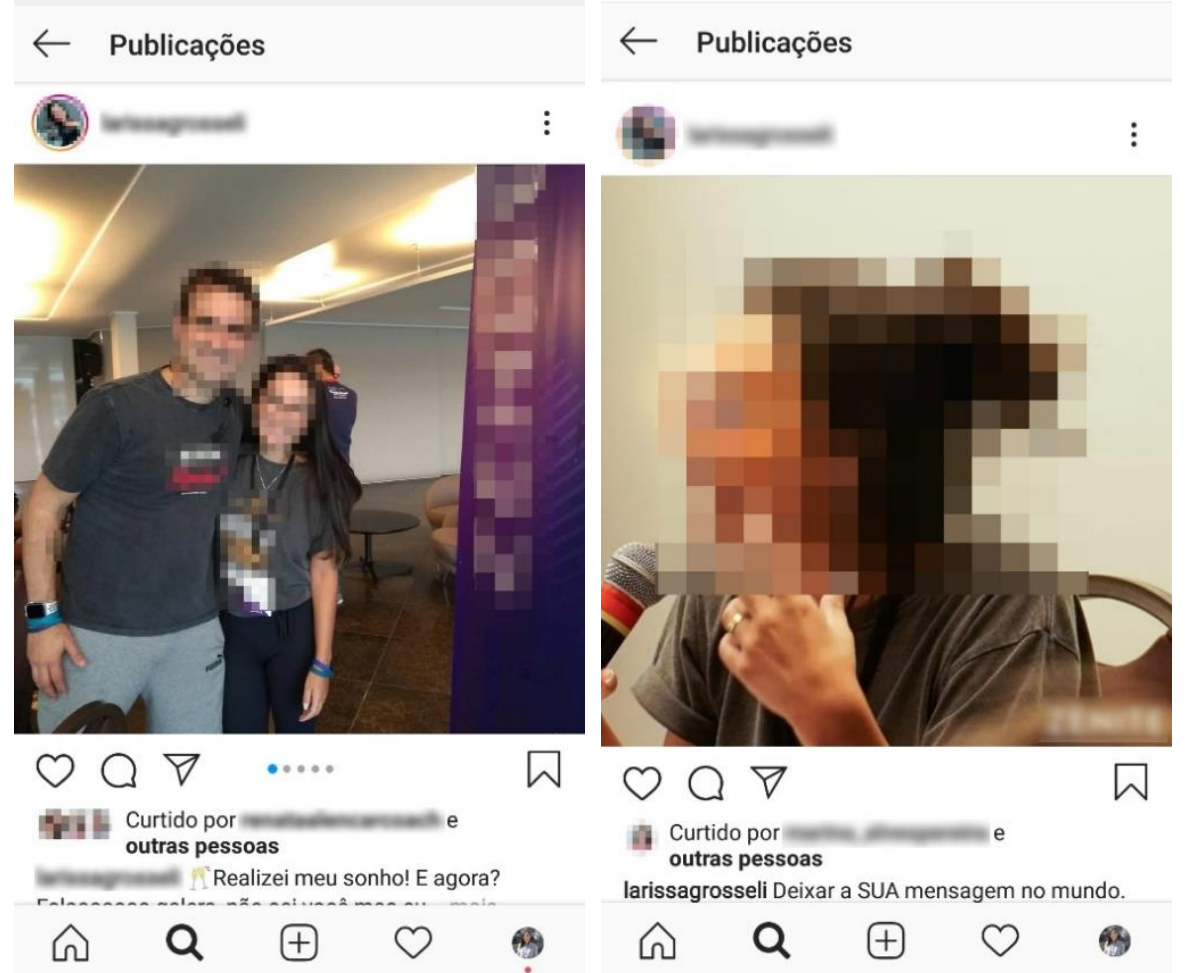

Legenda: na imagem à esquerda, Ana aparece ao lado de um homem que é palestrante reconhecido na área de coaching; esta publicação trouxe menção ao perfil dele. Fonte: print screen feito com smartphone a partir do perfil pessoal da pesquisadora.

Em quatro das seis postagens de destaque, Ana aparece sozinha na foto; duas das quatro fotos são selfies, nas quais ela aparece sorrindo. A postagem com mais curtidas e comentários está relacionada a uma data comemorativa, a Páscoa. Nela, Ana escolheu 
uma selfie, com uma legenda cujo tema é renascimento e o uso das seguintes hahstags: “\#VivaDeProposito", “\#renascer”, “\#pascoa2019”, “\#coaching” e “\#proposito”. É interessante observar que suas postagens contam, em geral, com perguntas e com o pronome "você", como no exemplo disponível na figura 23, cuja legenda inclui a seguinte frase: "Quem vai renascer em você?”.

Figura 23 - selfie no perfil de Ana.
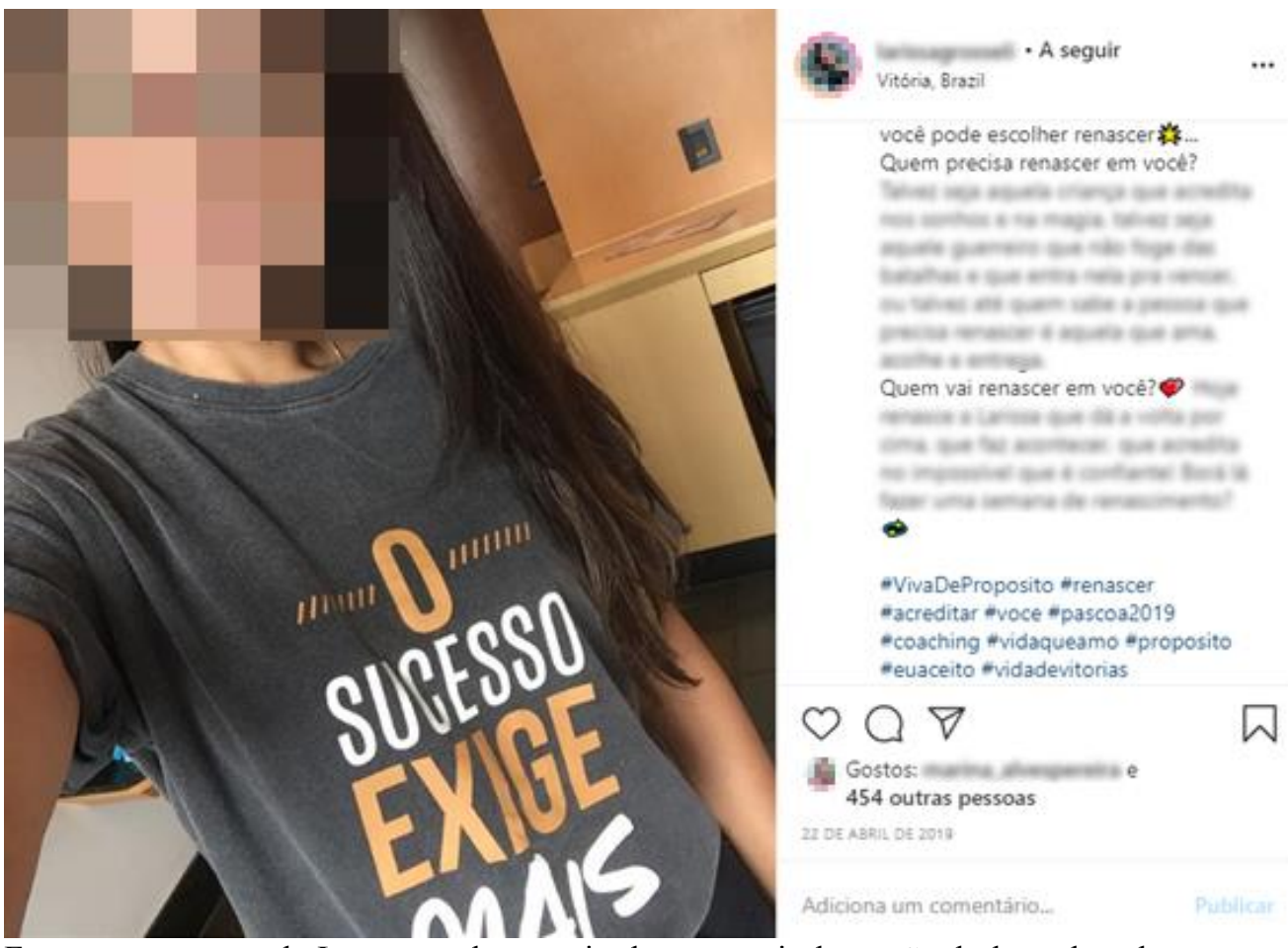

Fonte: print screen do Instagram da pesquisadora, a partir da versão desktop da rede.

Embora não haja menções diretas à carreira e à vida profissional nas postagens do feed analisadas, observamos que Ana fez um anúncio de seus serviços em uma postagem patrocinada, que chegou ao feed de nosso perfil, provavelmente porque estávamos seguindo o perfil de Ana e hashtags relacionadas a coaching, vida profissional, trabalho e carreira.

No anúncio, há uma foto que destaca os olhos azuis de uma mulher, acompanhada da pergunta: "gostaria de mudar a sua vida profissional em 2019?” (figura 24). A publicação patrocinada estava acompanhada de um botão "Saiba mais", que continha um link, e oferecia atendimento on-line e gratuito a quem desejasse definir o "rumo profissional de sucesso absoluto". Ao clicar em "Saiba mais", o usuário era direcionado a uma página cujo conteúdo versava sobre insatisfação no trabalho e sobre como ter a vida que sempre sonhou por meio de um atendimento on-line com Ana, como pode ser 
observado na figura 25. Para agendar o serviço, era necessário fornecer dados pessoais como nome e e-mail.

Figura 24 - postagem patrocinada feita pelo perfil de Ana.

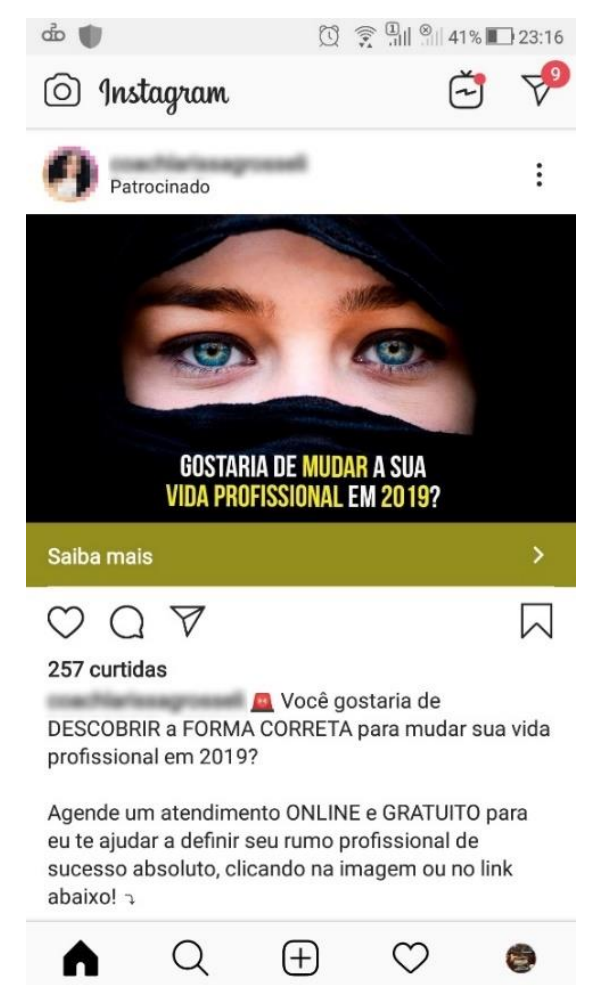

Fonte: print screen feito com smartphone a partir do perfil pessoal da pesquisadora.

Figura 25 - anúncio originário de postagem patrocinada no perfil de Ana.

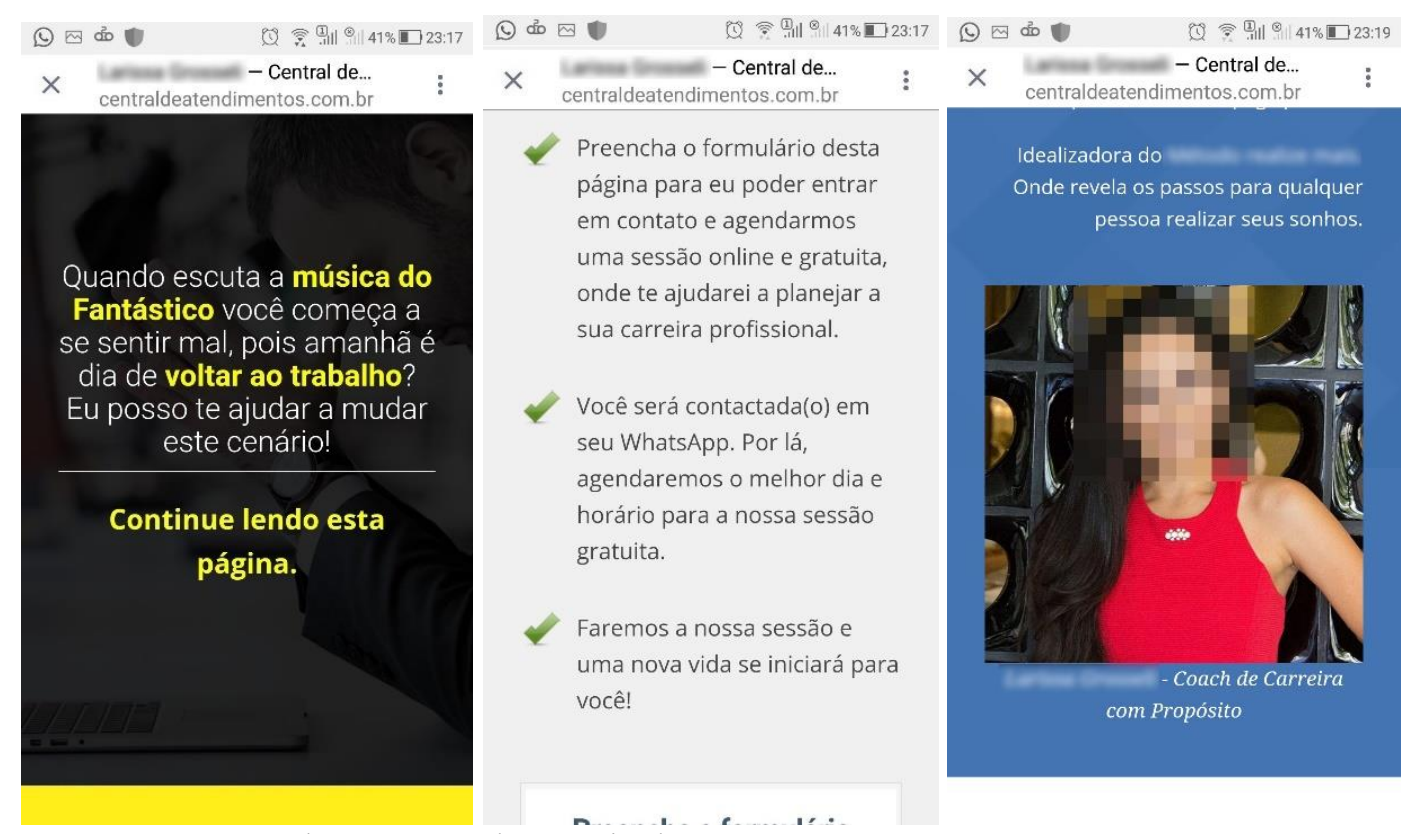

Fonte: print screen do Instagram da pesquisadora. 


\subsubsection{Publicações de Bia}

As publicações de Bia no feed trazem seu estilo de vida como destaque, em imagens que mostram viagens pelo Brasil, praia, piscina e rotina de exercícios físicos. Muitas fotos apresentam como localização a cidade do Rio de Janeiro, em especial a Barra da Tijuca, bairro nobre da cidade.

Há ainda grande destaque para postagens com fotos de livros e imagens em que Bia aparece trabalhando com seu notebook Macbook, da marca Apple. Das seis postagens com mais interações, três são fotos de livros; Bia aparece sozinha nas outras três imagens: em uma delas ela está na piscina e veste óculos escuros; na outra imagem ela segura um microfone; e a terceira é uma selfie na qual Bia segura uma xícara estampada com seu nome. Apenas uma das seis fotos não têm localização; as outras trazem Rio de Janeiro e Barra da Tijuca como localização.

Figura 26 - postagens no perfil de Bia.

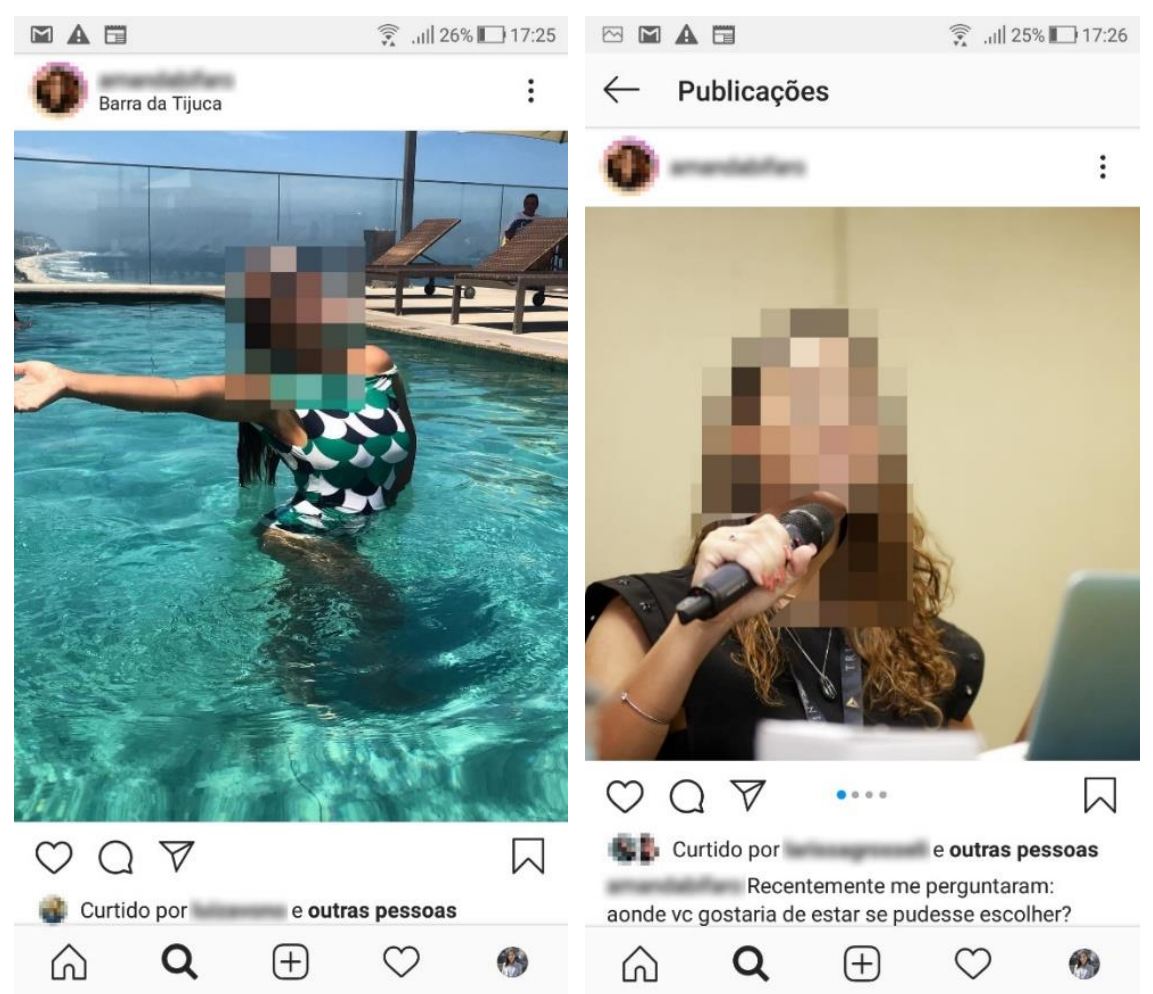

Fonte: print screen feito com smartphone a partir do perfil pessoal da pesquisadora.

As fotografias que compõem o feed de Bia são bem produzidas, com bons enquadramentos e luz. Nas postagens de fotos de livros, ela faz recomendações das obras e destaca o tema e aprendizados relacionados à leitura. As legendas dessas postagens 
também acompanham perguntas em linguagem informal, como a seguinte, que aparece na figura 27: "Me conta aí se já leu esse e o que achou!".

Figura 27 - postagem sobre livro no perfil de Bia, com legenda ao lado.

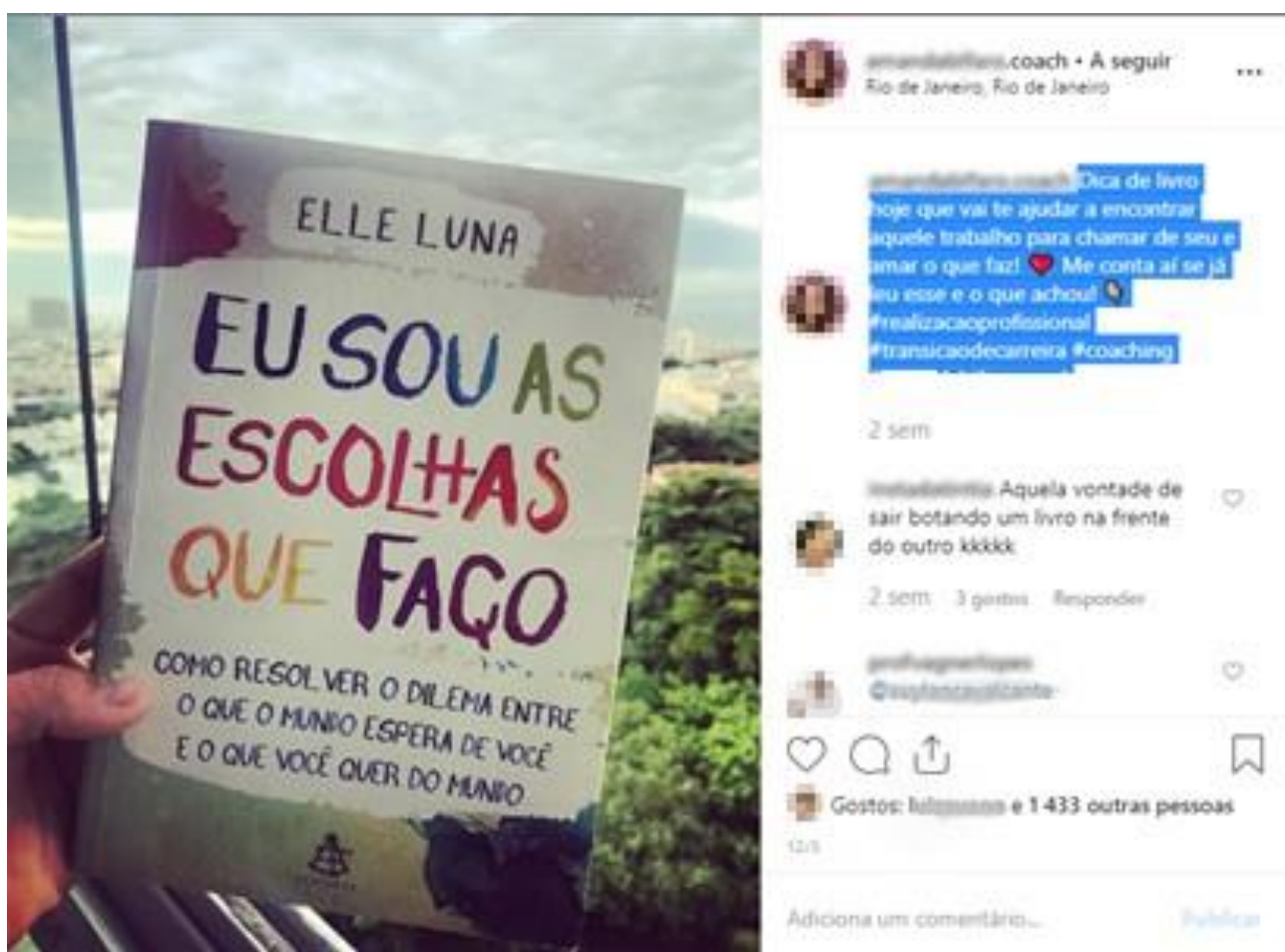

Fonte: print screen feito a partir do perfil pessoal da pesquisadora, com a versão desktop do Instagram.

Já nas fotografias em que aparece, Bia faz legendas mais longas, com reflexões relacionadas à felicidade, à gentileza, à autenticidade e à realização de sonhos, como no trecho a seguir, que acompanha a imagem da piscina, disponível na figura 26: "Eu sou tão bem resolvida com tanta coisa que falo sim, das minhas inseguranças e questões. Não temos problemas mas sim oportunidades de melhorar. [...] Meu convite para você é esse, SEJA VOCÊ."

Em cinco das seis postagens com mais interações, Bia usou as hashtags: “\#realizacaoprofissional", "\#transicaodecarreira", "\#coaching” e “\#realizacaoprofissional”, além de hashtag própria, formada por seu nome e sobrenome, acompanhada da palavra coach.

\subsubsection{Publicações de Ciro}

Dentre as seis postagens com mais interações no perfil de Ciro, metade traz imagens dele realizando uma apresentação, vestindo microfone de cabeça, nas quais em 
duas delas ele está no palco de um grande evento; e a outra metade são fotos de Ciro ao lado de sua companheira em viagens internacionais, todas com localização marcada na postagem. As postagens ao lado da companheira (figura 28) trazem legendas sobre o relacionamento, com menções ao perfil da mulher, emojis de coração e a hashtag \#tbt. ${ }^{85}$

Figura 28 - foto do feed de Ciro.

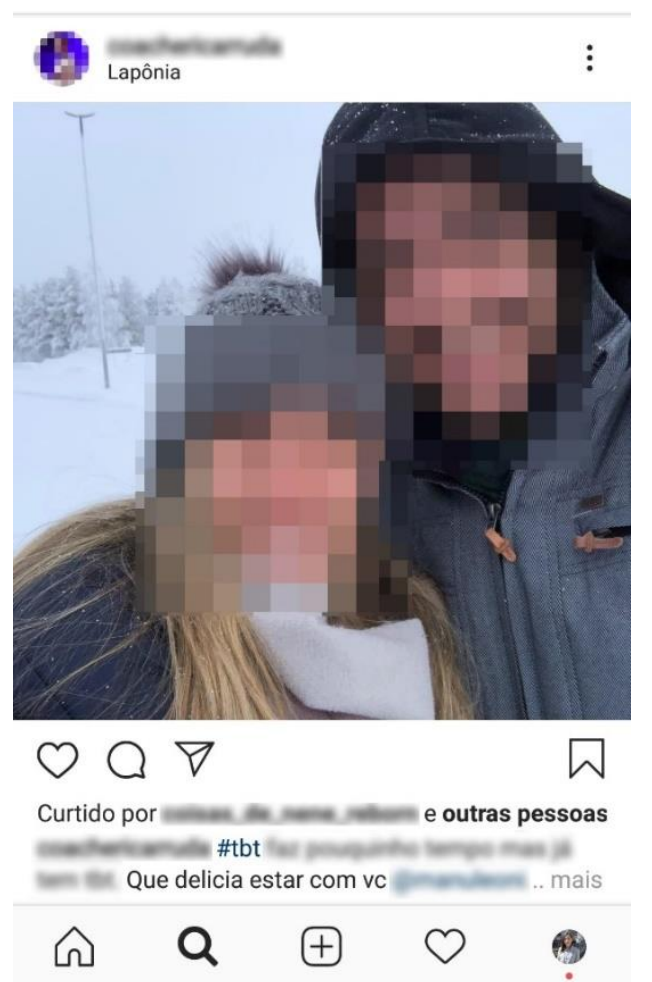

Fonte: print screen feito com smartphone a partir do perfil pessoal da pesquisadora.

Duas das três imagens em que Ciro aparece sozinho são dedicadas a mensagens relacionadas ao mundo do trabalho, nas quais os temas são: "celebrar pequenas conquistas" e "acreditar em si mesmo". Nelas, Ciro usa as hashtags "\#coaching", “\#coachdecarreira", “\#carreira”, “\#trabalhoideal”, “\#realizaçãonacarreira” e “\#trabalhodossonhos", além de uma hashtag própria, formada por seu nome seguido da palavra coach, como na figura 29.

\footnotetext{
${ }^{85}$ Tbt significa throwback Thursday, uma gíria do inglês que significa, em português, algo como "quintafeira do retorno ou de volta ao passado". A hashtag \#tbt é usada por usuários do Instagram e outras redes sociais para marcar fotos que se referem ao passado e trazem saudades, publicadas em geral às quintasfeiras.
} 
Figura 29 - foto e legenda no feed de Ciro.

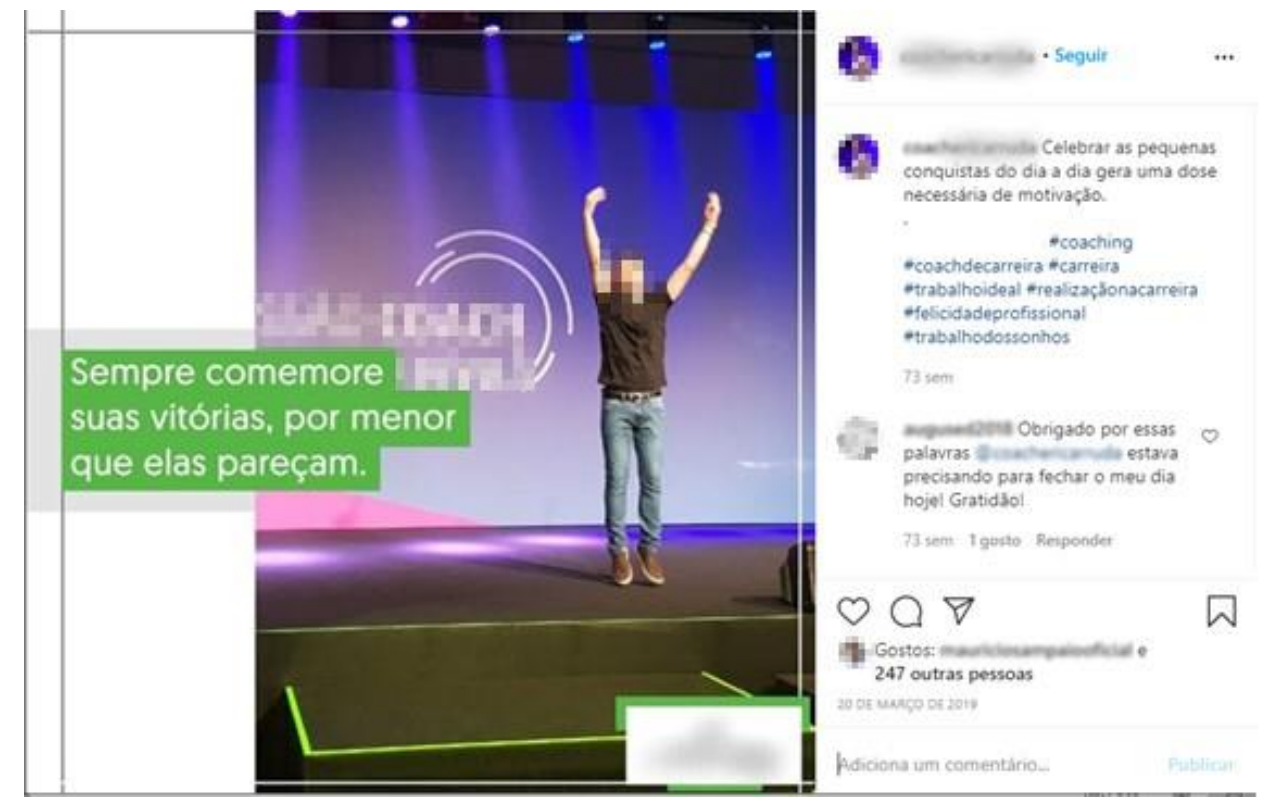

Fonte: print screen feito a partir do perfil pessoal da pesquisadora, com a versão desktop do Instagram.

Em publicação composta por imagem em que Ciro está em um evento com plateia, a legenda traz a menção ao perfil de uma figura pública na área de coaching, a mesma citada por Ana, junto com um agradecimento, como pode ser observado na figura 30.

Figura 30 - publicação de Ciro com legenda e menção a outro perfil.

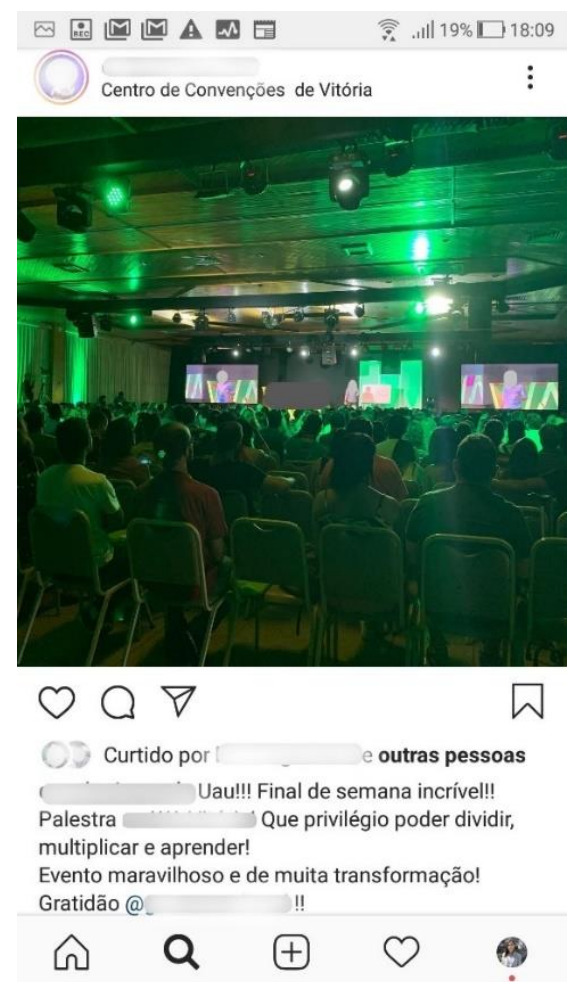

Fonte: print screen feito com smartphone a partir do perfil pessoal da pesquisadora. 


\subsubsection{Publicações de Duda}

As publicações no feed de Duda trazem principalmente imagens dela em viagens internacionais, registros de eventos nos quais ela é palestrante, foto de capas de livros com sugestões de leitura na legenda e fotos de Duda usando um notebook.

Das seis postagens que receberam mais interações (curtidas e comentários) no período analisado, duas trazem imagens de viagem à Nova York, nas quais ela aparece sozinha; uma apresenta Duda no carnaval no Sambódromo da Marquês de Sapucaí, no Rio de Janeiro; a quarta é uma imagem em que ela aparece em uma sala com dois notebooks e outras pessoas, durante um evento promovido por ela; na quinta imagem, Duda está sentada ao lado de outra coach, em postagem que convida seguidores para um grupo secreto no WhatsApp no qual as duas profissionais vão fornecer dicas sobre careira; e na última postagem, Duda está caminhando com fones de ouvido, com a legenda “Happy Birthday!”, em referência a seu aniversário.

As postagens dedicadas a viagens e a outros momentos da vida pessoal de Duda acompanham legendas sobre a importância do equilíbrio entre vida pessoal e profissional e do planejamento para realizar sonhos, além de relatos de situações de seu cotidiano, seguidas de hahstags como "\#férias", “\#vacation", “\#equilibrio" e "\#hapiness".

Figura 31 - foto de viagem no feed de Duda, com legenda.

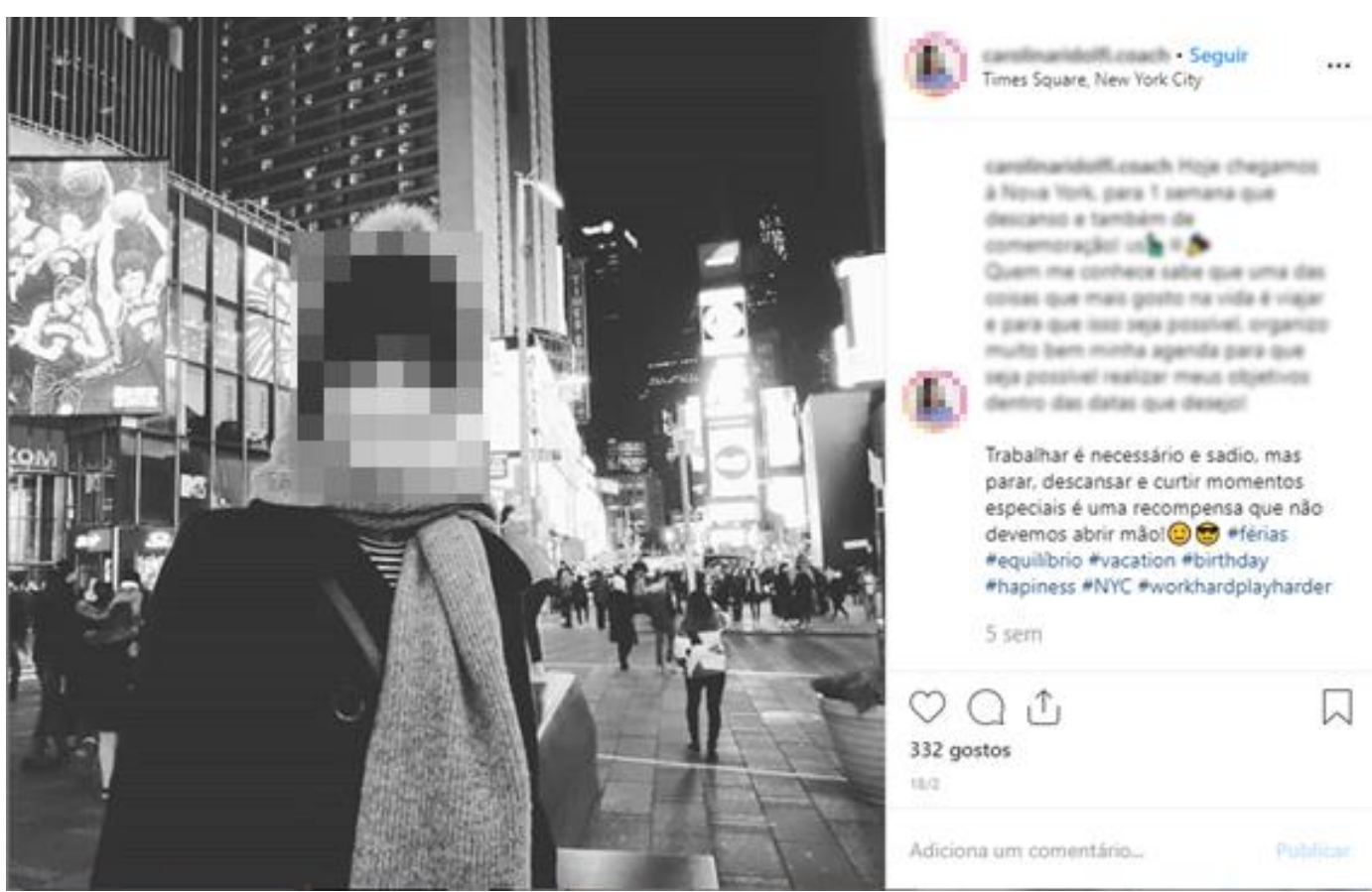

Fonte: print screen feito a partir do perfil pessoal da pesquisadora, com a versão desktop do Instagram. 
Já as legendas de postagens cujo tema é a atuação profissional de Duda versam sobre sua realização e satisfação com seu trabalho e seu propósito de vida, destacam sua "missão em ajudar pessoas no desenvolvimento pessoal" e trazem incentivos para que sua audiência envie mensagens a ela.

Observam-se frases informais, em tom de conversa, e o uso do pronome "você", como no seguinte exemplo, que pode ser observado na legenda da postagem disponível na figura 32: "É notório o tanto que eu tô feliz e realizada com o meu trabalho, não é mesmo? \".

Figura 32 - foto com legenda no feed de Duda.

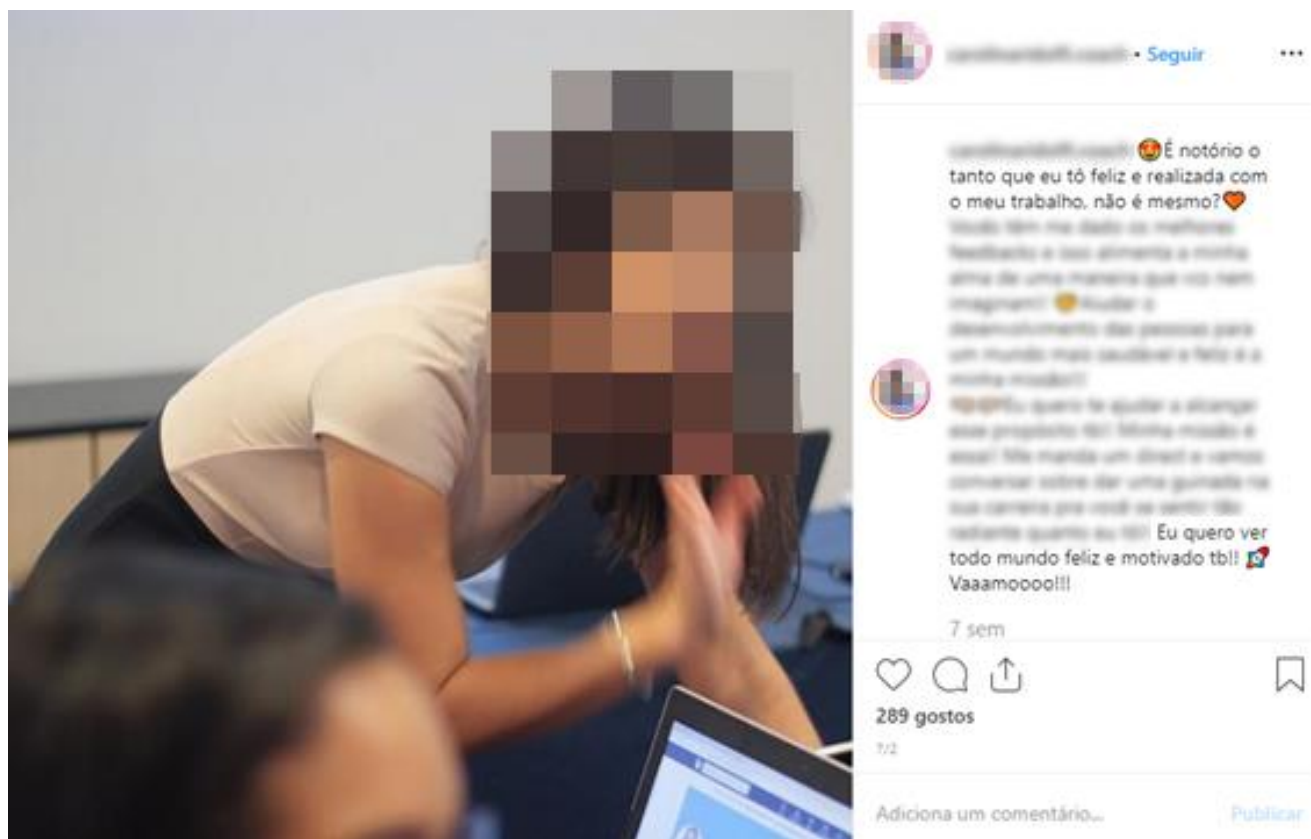

Fonte: print screen feito a partir do perfil pessoal da pesquisadora, com a versão desktop do Instagram.

\subsubsection{Publicações de Edi}

As publicações de Edi em seu feed se dividem entre imagens ao lado de sua companheira, fotos da tela de seu notebook MacBook, da Aple, imagens de Edi trabalhando em seu notebook, fotos de capas de livros, infografias com dicas sobre carreira e prosperidade, e fotografias em que Edi está com microfone de cabeça, em apresentações em cima de um palco.

No período analisado, das seis publicações com mais curtidas e comentários, três são fotografias em que Edi está com sua companheira; uma delas é a fotografia da capa 
de um livro; a quinta é uma foto em que Edi aparece com outros dois coaches conhecidos no mercado nacional, um deles é o mesmo já citado por Ana e Ciro; e a sexta postagem é uma infografia sobre falta de tempo, que traz legenda com a pergunta "E você, utiliza bem o seu tempo? Comente" e as hashtags "\#planejeseutempo" e "\#semdesculpa". De modo geral, Edi usa poucas hashtags; a mais usada é \#coachingdecarreira.

Figura 33 - fotografia de livro no feed de Edi.

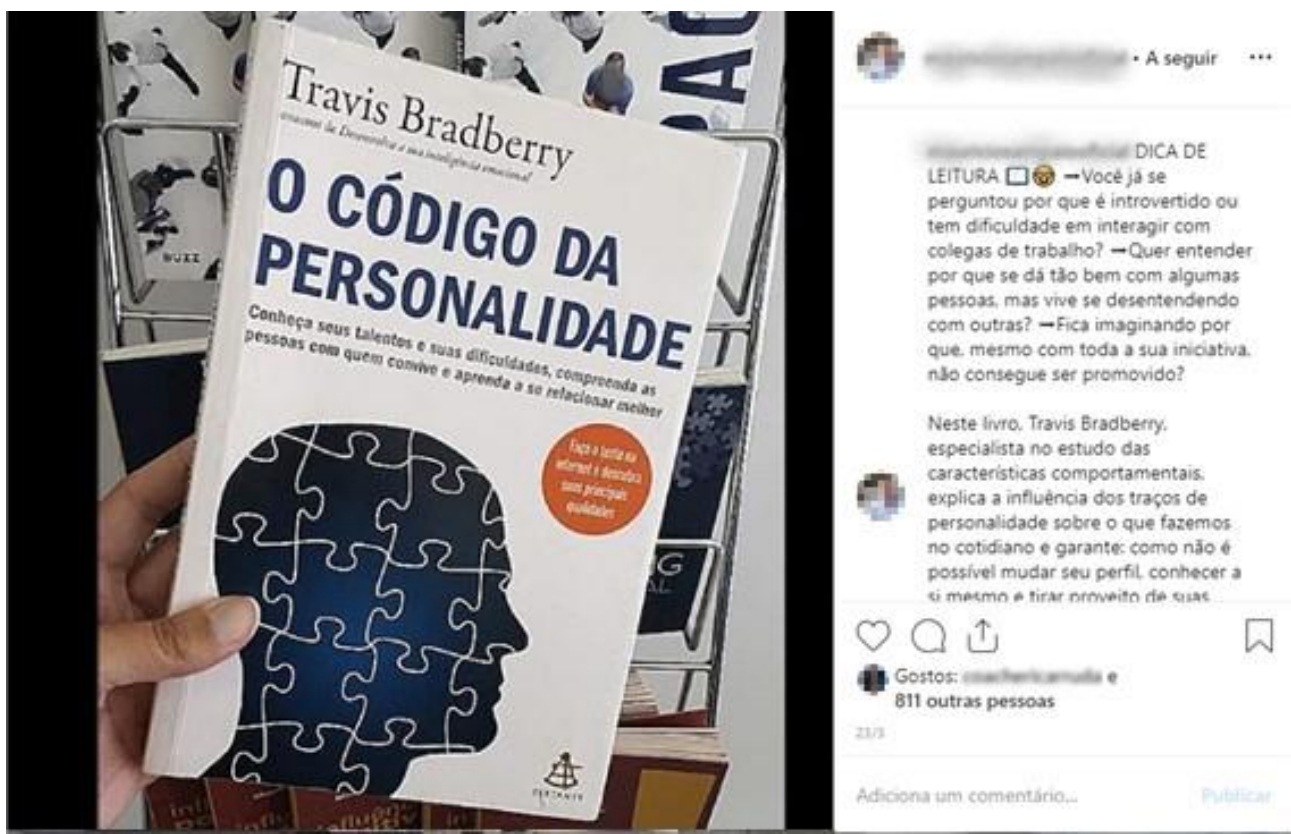

Fonte: Fonte: print screen feito a partir do perfil pessoal da pesquisadora, com a versão desktop do Instagram.

Nas publicações dedicadas a livros, Edi faz legendas com sugestões de leitura e perguntas à audiência sobre temas relacionados à obra, como no exemplo acima, que apresenta questões como: "você já se perguntou por que é introvertido ou tem dificuldade de interagir com colegas de trabalho?". Nesse tipo de postagem, Edi usa hashtags relacionadas ao título da obra. No caso acima, ele usou as seguintes hashtags: “\#dicadeleitura", “\#ocódigodapersonalidade" e "\#travisbradberry".

Em fotografias ao lado de outras pessoas, Edi menciona seus perfis no Instagram e faz agradecimento e/ou elogios a elas. No caso da figura 34, Edi aparece em imagem junto com um homem que é figura pública conhecida na área do coaching, o mesmo já citado em postagens de Ana e Ciro. 
Figura 34 - fotografia de Edi ao lado de duas pessoas.

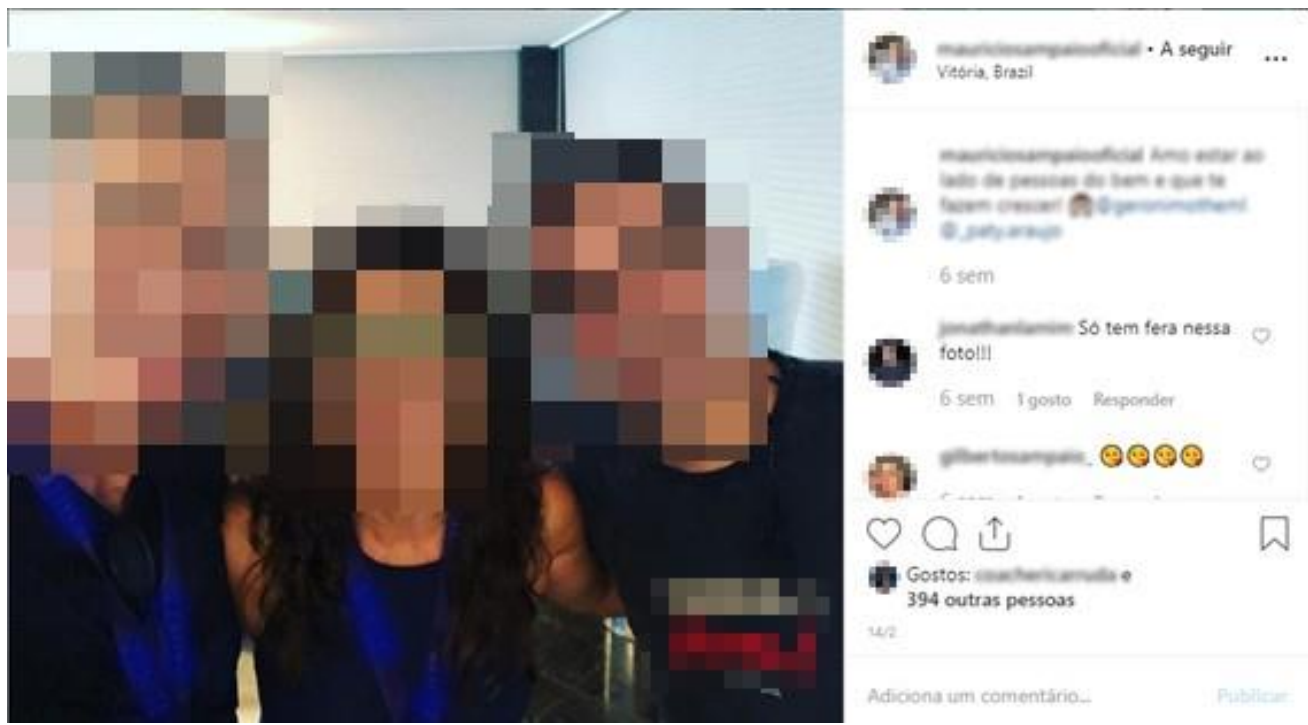

Fonte: print screen feito a partir do perfil pessoal da pesquisadora, com a versão desktop do Instagram.

As imagens ao lado de sua companheira trazem legendas curtas, que celebram a união ou valorizam momentos de lazer. Algumas trazem localização, como no caso da figura 35, que indica "Petrópolis, Rio de Janeiro, Brasil". Embora não apresentem hashtags, as fotos de momentos da vida particular do casal estão entre as postagens do feed com mais interações.

Figura 35 - fotografia de Edi com a companheira.
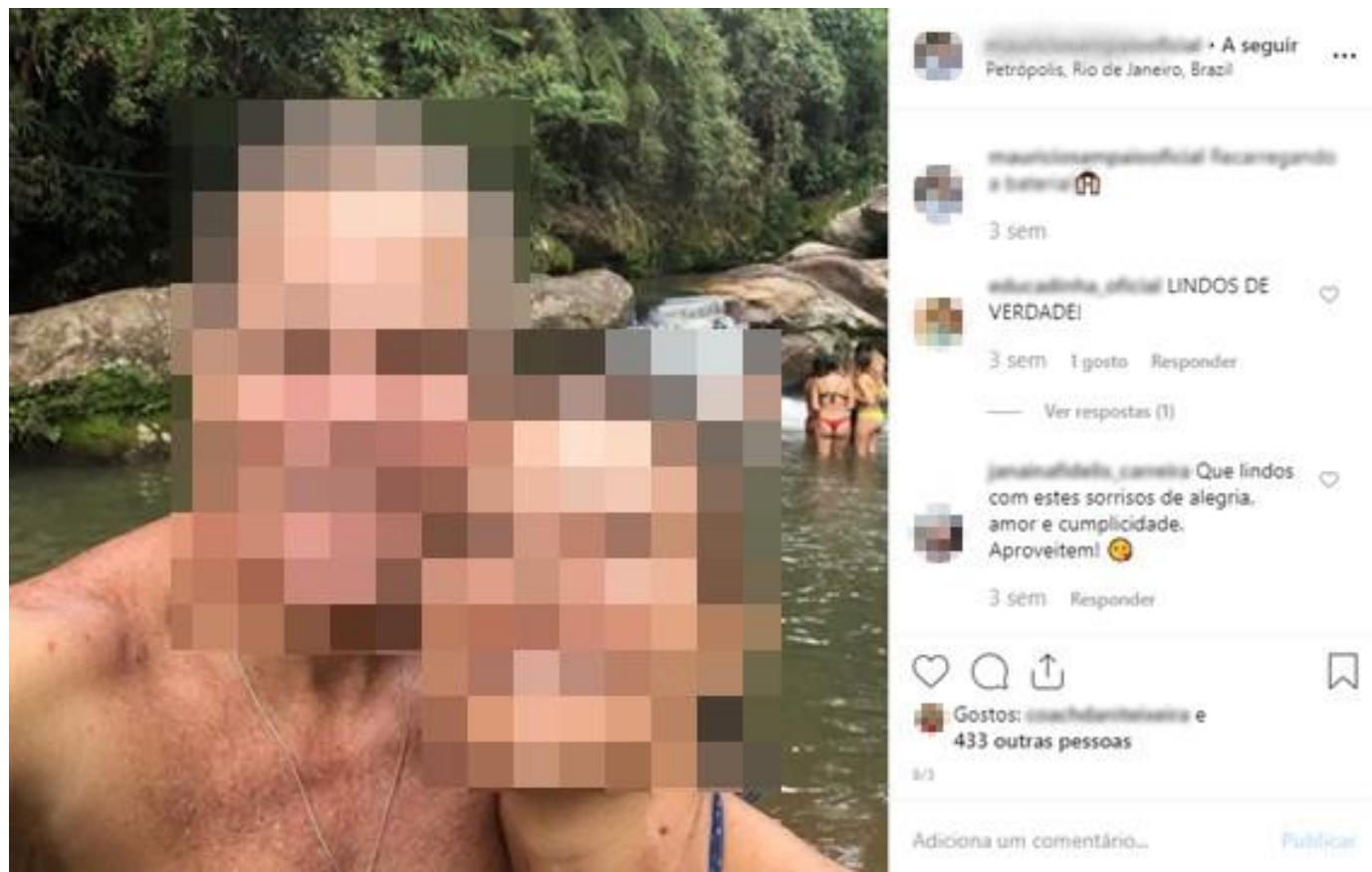

Fonte: print screen feito a partir do perfil pessoal da pesquisadora, com a versão desktop do Instagram. 
Como no caso de Ana, recebemos em nosso feed um anúncio do perfil de Edi. Nele, o coach oferece curso de formação em coaching de carreira, em legenda que traz a pergunta: "você já se imaginou contribuindo para a carreira de milhares de pessoas?" (figura 36). Ao clicar no link do anúncio, observamos os argumentos do serviço oferecido, que incluem "metodologia exclusiva" e "treinadores altamente capacitados" (figura 37).

Figura 36 - postagem patrocinada do perfil de Edi no feed do Instagram.

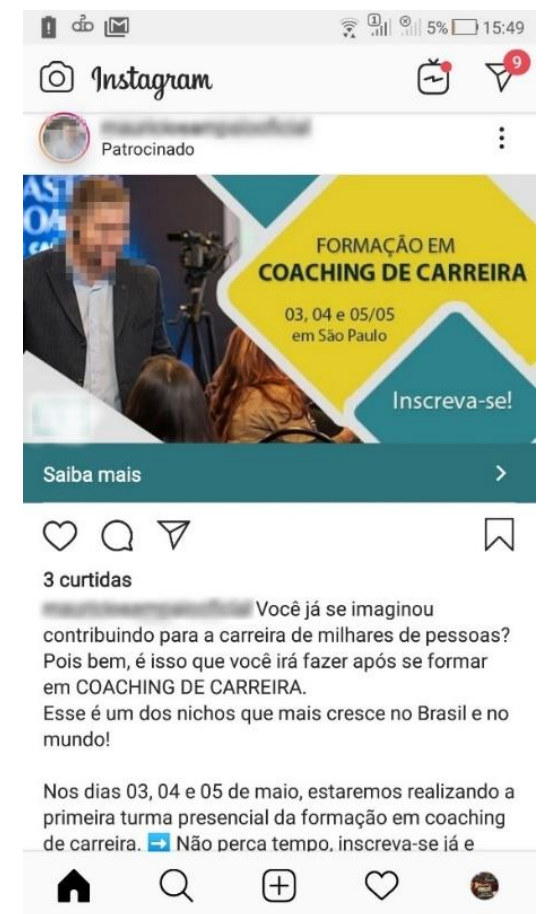

Fonte: print screen feito a partir do perfil pessoal da pesquisadora.

Figura 37 - publicidade no perfil de Edi.

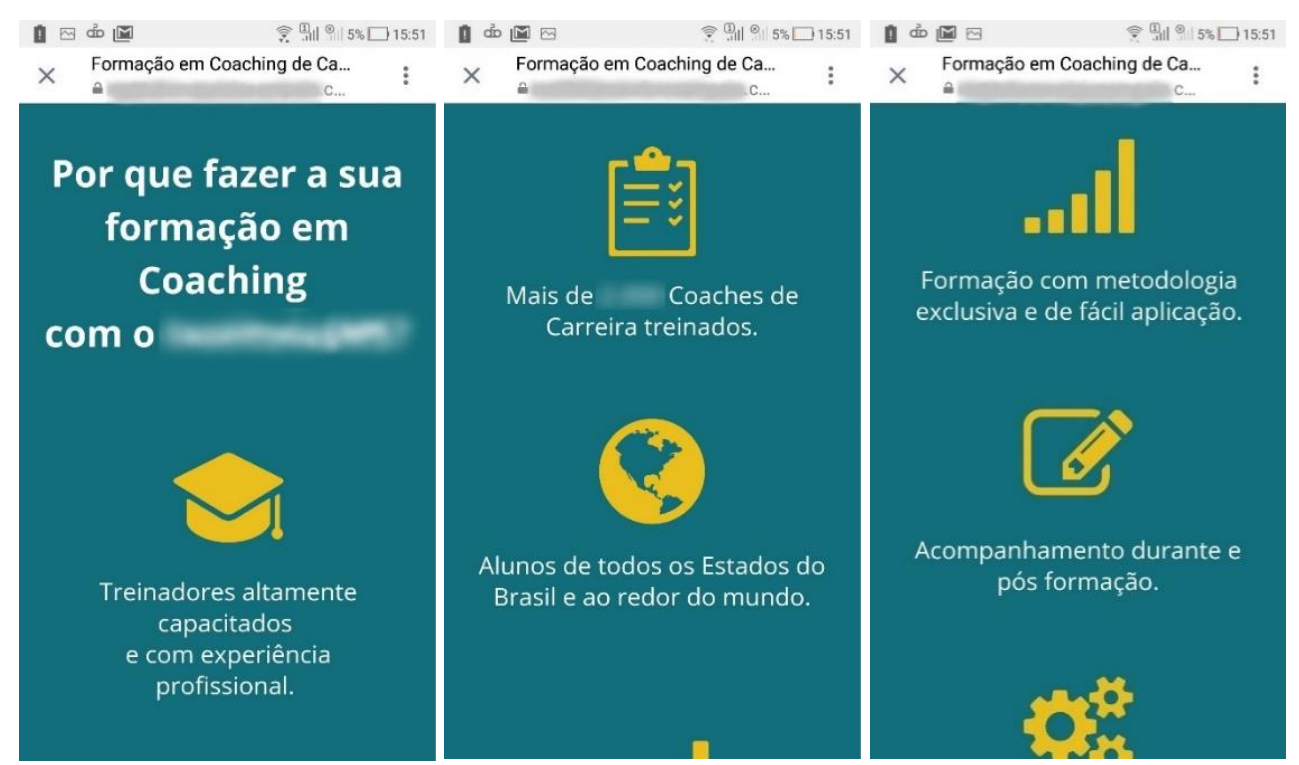

Fonte: print screen feito a partir do perfil pessoal da pesquisadora. 


\subsubsection{Publicações de Fabi}

As publicações de Fabi no período analisado concentram-se principalmente em sugestões de livros, nas quais Fabi posa ao lado das capas; e infografias com dicas sobre carreira e frases motivacionais. Há também fotografias nas quais ela aparece se apresentando como palestrante ou ao lado de grupos, em eventos ministrados por ela.

Dentre as seis publicações com mais interações, duas são fotografias de Fabi com livros; três são infografias com frases motivacionais e uma é uma imagem em que Fabi está na Austrália.

Figura 38 - fotografia de Fabi em viagem internacional.

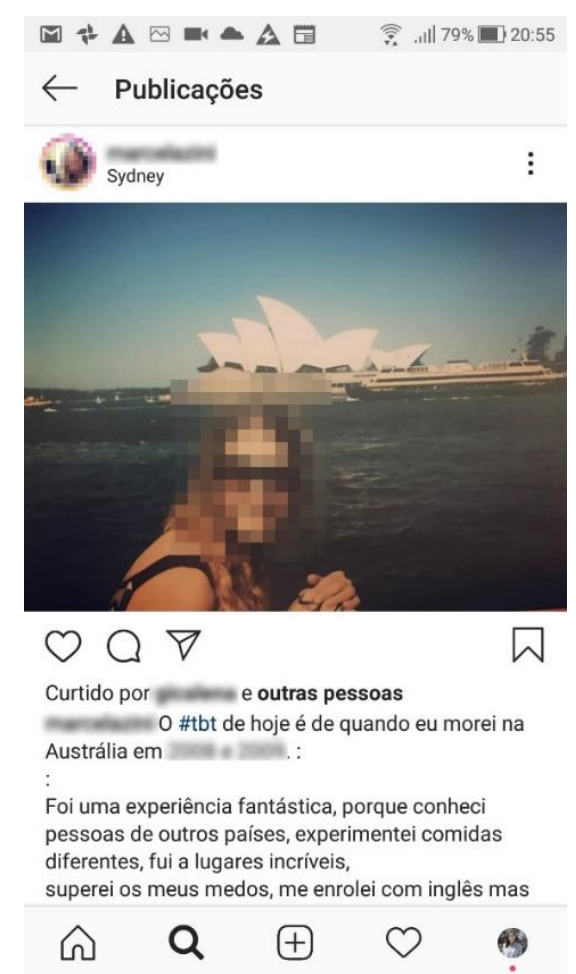

Fonte: print screen feito a partir do perfil pessoal da pesquisadora.

A publicação sobre a Austrália traz um relato de vida no qual Fabi conta sua experiência de ter morado naquele país. Na imagem, ela aparece em destaque, em frente à Ópera de Sidney, cartão postal da cidade homônima. A legenda tem como principais assuntos a superação de medos, o aprendizado de um novo idioma e a realização de sonhos, como na seguinte frase: "Sem falar que esse tempo em Sydney me mostrou que sonhar vale a pena e que fazer o nosso sonho acontecer é melhor ainda". A postagem acompanha a localização (Sydney) e as seguintes hashtags: "\#maiscoragem", “\#queroseusucesso", “\#vamosjuntos”, “\#mudarasuavida" e "\#coachingdecarreira". 
Nas postagens sobre livros (figura 39), Fabi comenta o tema principal de cada obra, em linguagem informal e o uso do pronome você. Ela sempre utiliza as hashtags "\#dicadelivro", e “\#coachdecarreira" ou "\#coachingdecarreira", seguidas de hashtags que remetem à obra indicada; no caso acima, acompanham a postagem as hashtags “\#augustocury", “\#crisedeansiedade" e "\#temcura".

Figura 39 - fotografia de Fabi com livro nas mãos, com legenda.

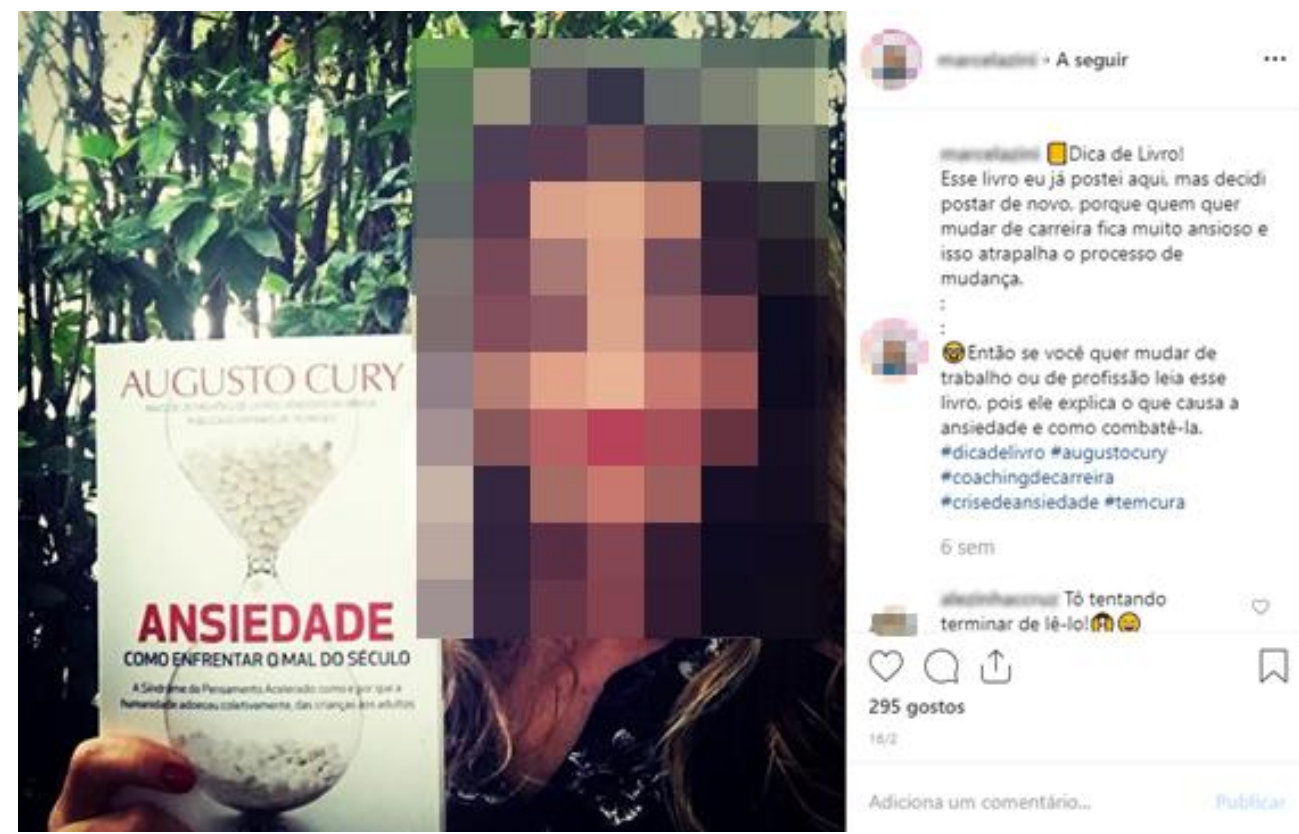

Fonte: print screen feito a partir do perfil pessoal da pesquisadora, com a versão desktop do Instagram.

Figura 40 - imagem no feed de Fabi.

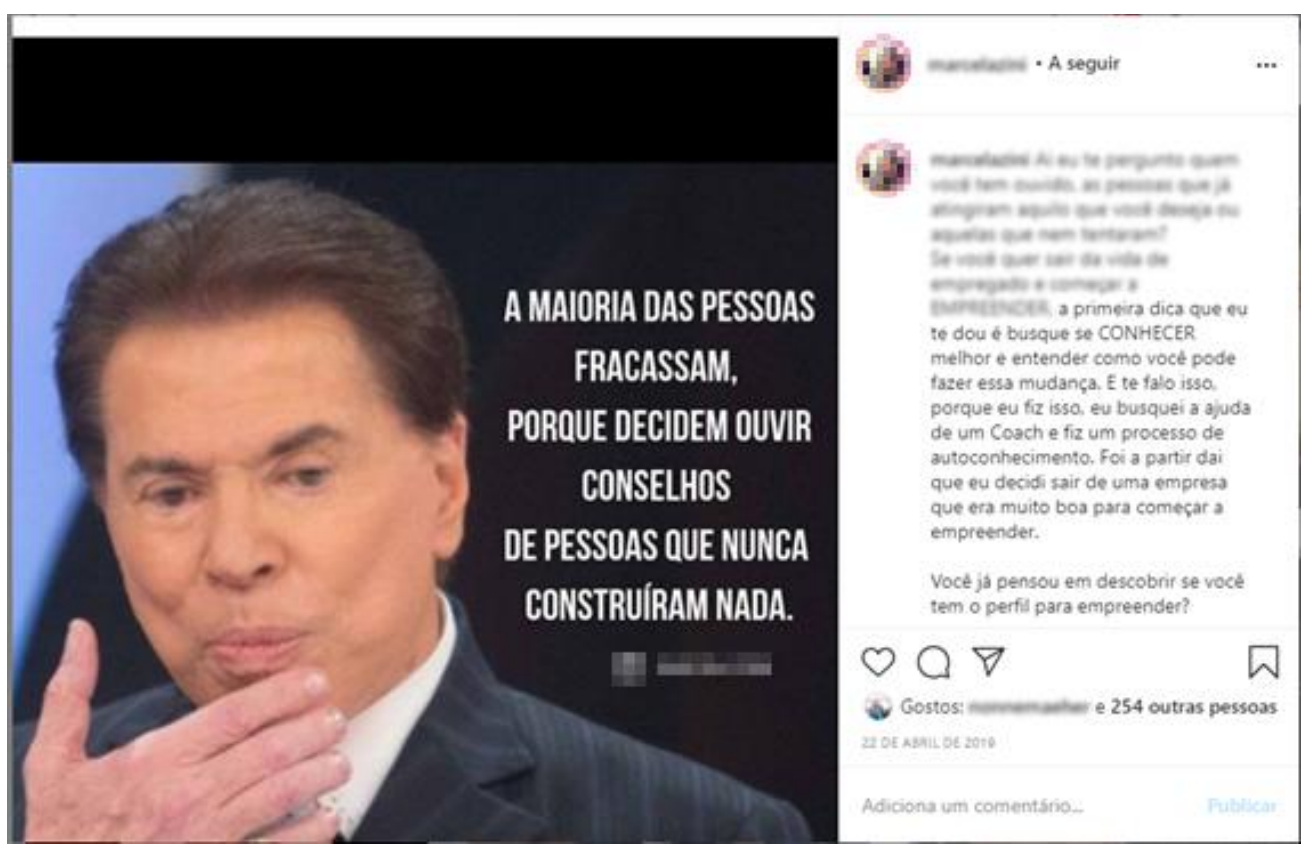

Fonte: print screen feito a partir do perfil pessoal da pesquisadora, com a versão desktop do Instagram. 
As publicações de infográficos com dicas e frases motivacionais são acompanhadas de legendas que tratam sobre crescimento, empreendedorismo, autoconhecimento, sonhos, felicidade e produtividade. Nos textos, escritos em tom informal, há perguntas como "Você já pensou em descobrir se você tem o perfil para empreender?", observada na figura 40. Nesse tipo de postagem, ela usa hashtags como “\#empreender”, “\#mudesuavida”, “\#profissão", “\#realizacao”, “\#satisfeito", “\#feliz”, “\#coachingdecarreira”, “\#crescerprofissionalmente” e "\#realizaçãoprofissional”.

\subsection{Análise semiótica das autorrepresentações em perfis profissionais}

Nesta seção, apresentamos a interpretação do fenômeno, coordenando a teoria aos dados coletados de modo a discutir e apontar respostas aos problemas propostos nesta pesquisa. Conforme destaca Lopes (2014, p. 152), “a análise interpretativa visa à explicação do fenômeno mediante operações lógicas de síntese e de amplificação levando a análise a um nível superior de abstração e de generalização.” Nesse sentido, buscaremos ampliar nossa compreensão sobre as autorrepresentações no ambiente digital à luz das bases teóricas mobilizadas ao longo da dissertação.

Em primeiro lugar, entendemos que os perfis profissionais selecionados para análise foram criados principalmente com o propósito de divulgar o trabalho dos coaches de carreira e vender seus serviços. Assim, do ponto de vista dos elementos da semiose, podemos afirmar que o objeto dinâmico de cada perfil, este último entendido como um conjunto de signos, é o ideal de profissional capaz de ser o treinador de sucesso para a carreira do potencial cliente. Para comunicar essa ideia, os coaches selecionaram diversos signos que carregam interpretantes imediatos relacionados ao ideal de sucesso e de profissionalismo.

Observamos, por exemplo, que a escolha de imagens nas quais os coaches aparecem segurando microfones, durante eventos com plateia (figura 41), carregam a ideia de profissionais bem-sucedidos em suas áreas de atuação, uma vez que palestrantes são pessoas que supostamente têm grande conhecimento acumulado, entre outras conquistas profissionais. As postagens frequentes de fotos de capas de livro também têm a possibilidade de gerar interpretantes dinâmicos relacionados à ideia de capacitação e de conhecimento. Além do simbolismo inerente a essas imagens, as publicações são complementadas com legendas que apelam às emoções ao discorrer sobre sonhos e incluem hashtags que ajudam na rastreabilidade desses conteúdos. 
Figura 41 - imagens mostram coaches em palestras.

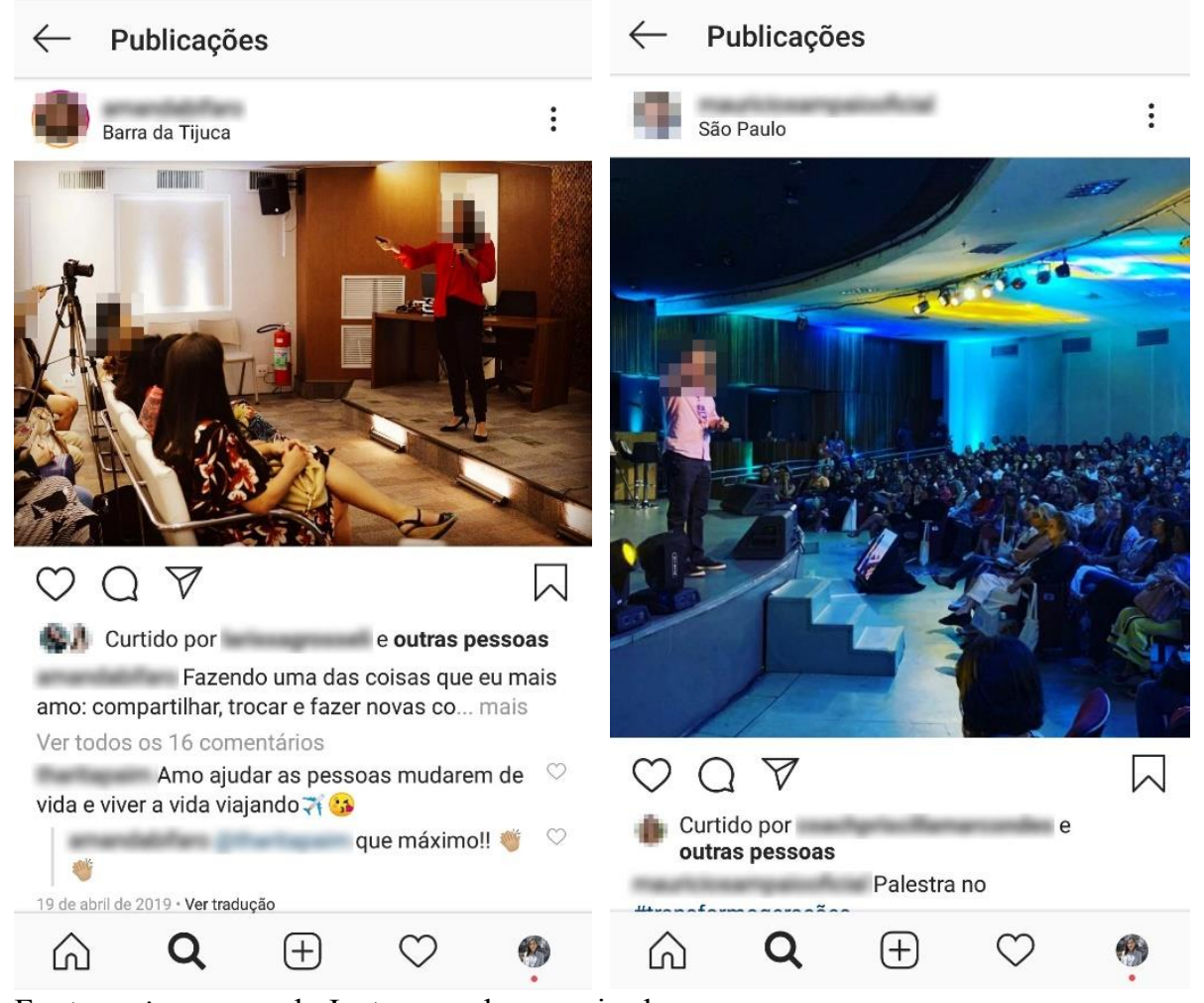

Fonte: print screen do Instagram da pesquisadora.

A escolha por destacar stories dedicados a depoimentos de clientes e ex-clientes e a sugestões de livros representam tentativas de gerar interpretantes dinâmicos relacionados à ideia de profissionalismo e de confiabilidade.

As imagens de estilo de vida, que incluem viagens, cafés, vinhos e notebooks, também carregam consigo a ideia de sucesso. Nos exemplos da figura 42, Duda (à esquerda) e Ana (à direita) aparecem trabalhando em seus notebooks em ambientes distintos de uma empresa tradicional, em postagens que acompanham legendas que destacam a satisfação de trabalhar com o que as apaixona.

Nos perfis de Duda, Ciro e Fabi, as fotografias de viagens internacionais aos Estados Unidos, à Finlândia e à Austrália, acompanhadas da localização, trazem a possibilidade de interpretantes dinâmicos relacionados a êxito pessoal e profissional. A marcação de localização, assim, ajuda a relacionar esses perfis aos valores simbólicos atrelados a esses locais. Nos perfis de Ciro e Edi, destacam-se as fotografias com suas companheiras, com possibilidades de gerar interpretantes relacionados ao equilíbrio entre vida pessoal e profissional. 
Figura 42 - postagens sobre trabalho com notebooks.

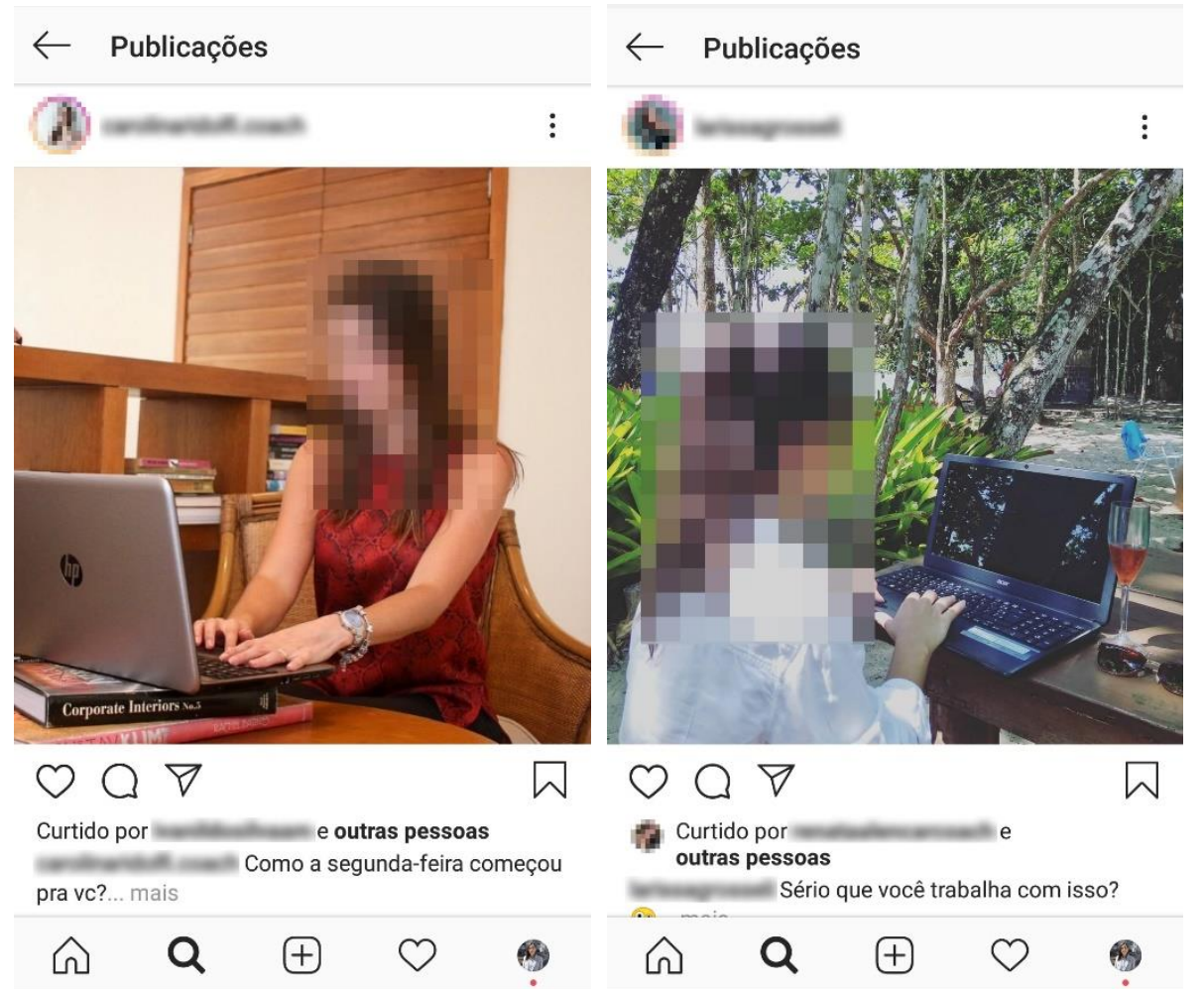

Fonte: print screen do Instagram da pesquisadora.

Mais do que identificar os tipos de signos e suas possibilidades de semiose, pontuamos que a geração de sentidos não ocorre de modo isolado; assim, uma fotografia, sozinha, não é capaz de gerar interpretantes alinhados aos propósitos desses coaches. Para gerar interpretantes, as autorrepresentações no Instagram reúnem belas imagens, textos capazes de gerar reações emocionais, hashtags que facilitem a encontrabilidade dos conteúdos, entre outros elementos. Nesse sentido, a maioria das publicações analisadas trazem distintas estratégias de representação.

Como pontuamos no segundo capítulo, as autorrepresentações no ambiente digital também dependem das interações e do capital social que elas geram (RECUERO, 2012). Se considerarmos as legendas das postagens, por exemplo, chama a atenção a recorrência de perguntas direcionadas à audiência, carregadas de pronomes pessoais e verbos no imperativo, que atuam como elementos de secundidade, capazes de provocar reações. Ao fazer perguntas do tipo “como a segunda-feira começou para vc?” (figura 42), as postagens estimulam conversações com a audiência. Nesse caso, as respostas e interações de outros usuários, entendidas aqui como interpretantes dinâmicos, podem assumir variadas funções: na camada das interfaces, elas geram capital social e, por tanto, mais valor aos perfis; além disso, quanto mais interações uma publicação obtém, mais ela gera 
interpretantes na camada dos códigos do Instagram, que passa a dar mais visibilidade ao perfil. Nos casos dos perfis de Ana, Ciro e Edi, observamos que, ao fazer menções em suas postagens ao perfil de uma figura pública da área de coaching, eles buscaram associar seus perfis aos valores de tal pessoa, que é referência em coaching.

As hashtags usadas nos perfis e nas postagens do feed, por sua vez, operam, considerando as características de funcionamento do Instagram, em nível de secundidade e terceiridade fenomenológica. No primeiro caso, elas ajudam a categorizar o perfil e as postagens do coach de carreira, permitindo que eles sejam conectados a outros conteúdos relacionados à mesma hashtag e encontrados em mecanismos de busca internos do Instagram. Aqui, cabe lembrar que o Instagram possui um sistema de busca por hashtags, o que evidencia seu domínio indicial.

Entretanto, ao incluir uma hashtag à biografia, o dono do perfil pode estar buscando, em primeiro lugar, associar sua representação ao valor simbólico atrelado à palavra-chave contida na hashtag, o que parece ter sido o caso do uso da hashtag "\#Vivadepropósito" na biografia do perfil de Ana. Ou seja, embora a hashtag possa ser rastreada, a forma como foi usada nesse caso aponta para uma carga simbólica mais evidente. Entendemos, assim, que as hashtags podem atuar em nível de secundidade e terceiridade ao mesmo tempo dentro do Instagram, auxiliando na categorização dos conteúdos para a rede e para os usuários e comunicando valores simbólicos aos possíveis intérpretes.

A partir da observação das hashtags usadas por Bia, Ciro e Fabi em suas publicações no feed - tais como "\#realizaçãoprofissional”, "\#coaching", "\#coachdecarreira”, “\#carreira”, “\#trabalhoideal”, “\#transiçãodecarreira” -, poderíamos afirmar que elas podem operar, concomitantemente, em nível de secundidade e de terceiridade fenomenológica, ou seja, elas ajudariam a categorizar os conteúdos, facilitando sua encontrabilidade, e a transmitir certos valores simbólicos estabelecidos por hábitos de ação relacionados ao uso dessas palavras-chave. O que queremos destacar em relação ao uso de hashtags é que, no caso do Instagram e na semiose em questão, embora não possamos assegurar em que domínio fenomenológico tais hashtags atuam, deve-se considerar que a presença de hashtags implica na possibilidade de distintos processos de representação em curso ao mesmo tempo, interconectados. Isso pode ser melhor compreendido se tomarmos o Sinequismo Peirceano como base para essas considerações, uma vez que essa doutrina nos mostra que os significados emergem de um contínuo. 
Chama a atenção o uso dos emojis "no alvo" (ㅇ) e "foguete" (\&) nas biografias dos perfis e nas legendas das publicações no feed. Se considerados como signos, esses emojis relacionam-se com o objeto (o ideal de profissional que os coaches desejam representar) no domínio fenomenológico de terceiridade, uma vez que atuam como regra ou convenção. Ou seja, nesses casos, os emojis operam como símbolos, e não como ícones. Isso fica claro quando observamos que, no universo do coaching, esses emojis são usados associados às ideias de resultados, sucesso, eficiência, produtividade e/ou alcance de metas. Em publicações no Instagram feitas ao longo de 2019, por exemplo, a Sociedade Brasileira de Coaching utilizou os emojis "foguete" e no "alvo" em algumas publicações no Instagram, como no seguinte exemplo:

Figura 43 - publicação em perfil verificado mostra figuras de foguete e alvo.

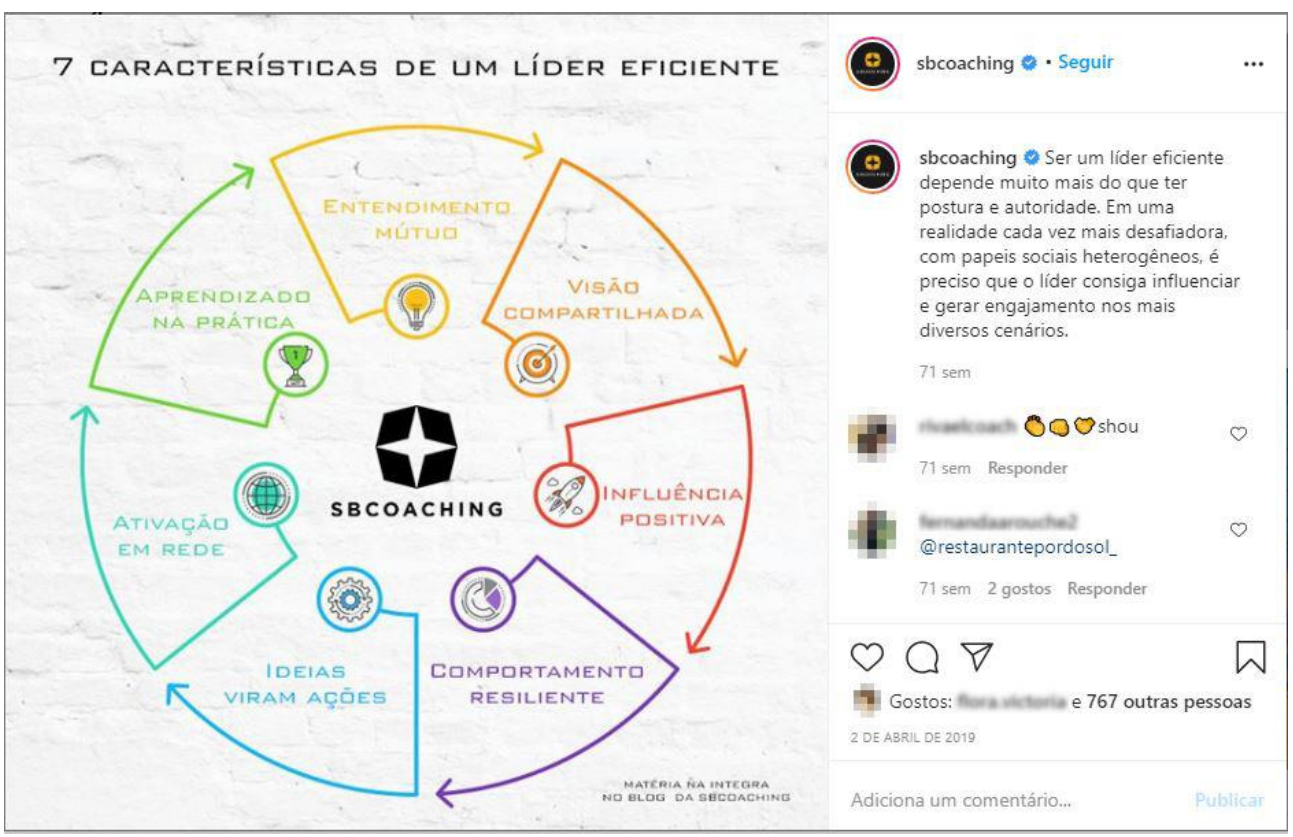

Fonte: print screen feito a partir do perfil pessoal da pesquisadora, com a versão desktop do Instagram.

De modo semelhante, o Instituto Brasileiro de Coaching usou esses emojis em suas publicações para se referir à ideia de sucesso, como pode ser observado na legenda que acompanha a publicação mostrada na figura 44 : 
Figura 44 - publicação com legenda que usa emoji "no alvo".

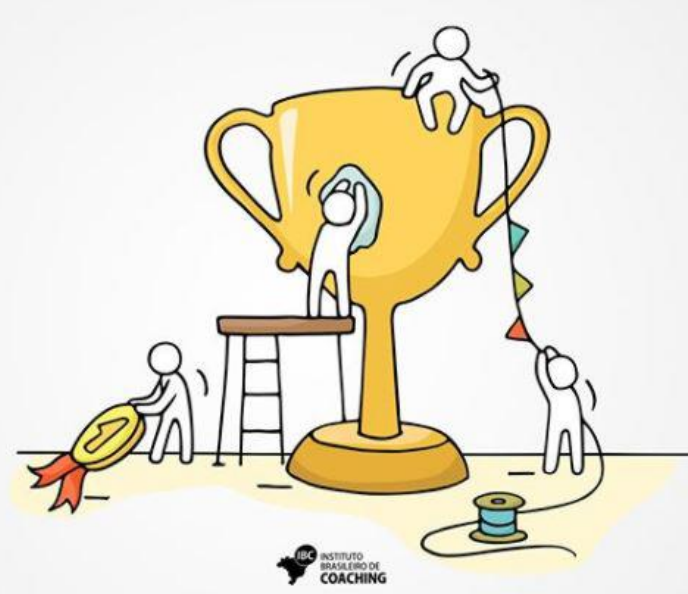

GRANDE OU PEQUENA, CELEBRE CADA VITÓRIA

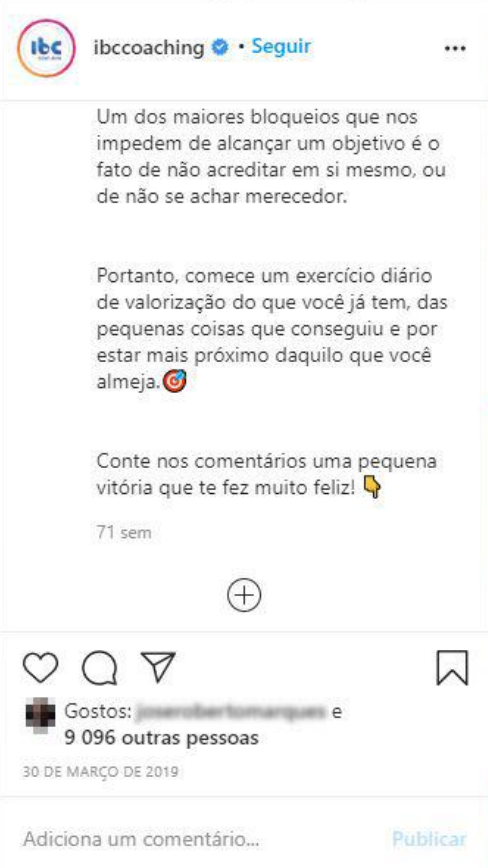

Fonte: print screen feito a partir do perfil pessoal da pesquisadora, com a versão desktop do Instagram.

O alvo também está presente na capa do best seller O Poder da Ação: faça sua vida ideal sair do papel, do coach Paulo Vieira:

Figura 45 - capa de livro best seller com figura de alvo.

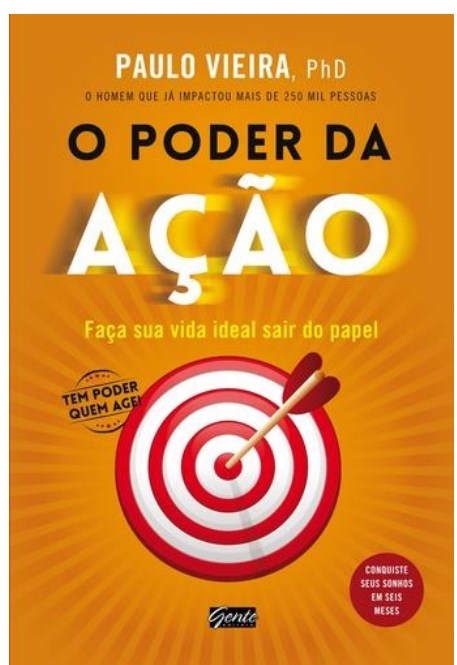

Fonte: reprodução de capa do livro O Poder da Ação: faça sua vida ideal sair do papel, publicado pela Editora Gente. Disponível em: < https://www.editoragente.com.br/o-poder-da-ac-o-prod.html > . Acesso em: 30 abr. 2019.

Os emojis de "seta para baixo" ( $\downarrow$ ) e "dedo indicador apontando para baixo" (ד) usados nas biografias dos perfis e em legendas de postagens no feed operam em nível de secundidade fenomenológica, como índices. Nos casos analisados, esses emojis foram 
usados para chamar a atenção para links que remetiam ao site do coach de carreira ou a uma árvore de links, que, por sua vez, direcionava a outros sites e redes sociais, como ao canal no YouTube, ao oferecimento de consultorias, à venda de produtos digitais, etc.

Entre os temas principais encontrados nos perfis, estão a realização de sonhos, relatos pessoais, histórias com lições aos moldes de autoajuda, exploração do estilo de vida por meio da exibição de fotografias de viagem e itens de consumo como livros, cafés e vinhos, produtividade, e uma tendência à valorizar o emaranhamento entre vida pessoal e profissional como ideal a ser atingido por aqueles que buscam sucesso na carreira.

Observamos, nesse sentido, um alinhamento aos valores do "capitalismo artista", uma vez que as publicações estão focadas em mobilizar desejos e afetos dos sujeitos, apelando para narrativas que exploram expectativas emocionais. Como destacam Lipovetsky e Serroy (2015, p. 42), "um capitalismo centrado na produção foi substituído por um capitalismo de sedução focalizado nos prazeres dos consumidores por meio das imagens e dos sonhos, das formas e dos relatos".

Embora o mundo do trabalho seja o foco dessas autorrepresentações, chama a atenção a falta de discussões sobre emprego e desemprego em cinco dos seis perfis selecionados; apenas Edi citou o desemprego. De modo geral, verificamos a ausência de temas negativos ou da problematização sobre falta de vagas no mercado formal, embora este seja um problema real relacionado ao mundo do trabalho. Para se ter uma ideia, a taxa de desemprego no primeiro trimestre de 2019 ficou em 12,7\%, de acordo com dados da Pesquisa Nacional por Amostra de Domicílios Contínua (Pnad Contínua), divulgada pelo Instituto Brasileiro de Geografia e Estatística (IBGE). ${ }^{86}$ Para Han (2018, p. 35), enquanto o negativo gera reflexão e toma tempo, a positividade simplifica o discurso e facilita seu enquadramento nas dinâmicas do sistema econômico vigente: "para o julgamento de gostar - I like (eu gosto) - não se faz necessário qualquer consideração mais vagarosa."

Constatamos nas postagens dos coaches temas como a responsabilização do sujeito pelo próprio sucesso e conquistas, em contexto alinhado às temáticas abordadas em perfis oficiais das instituições de coaching no Instagram. Nessa perspectiva, a legenda da publicação do Instituto Brasileiro de Coaching (figura 46) afirma que "assumir responsabilidades é um ponto crucial para assumir o controle de sua vida":

\footnotetext{
${ }^{86}$ Disponível em: < https://valor.globo.com/brasil/noticia/2019/04/30/brasil-tem-134-milhoes-dedesempregados-no-1o-trimestre-indica-ibge.ghtml>. Acesso em: 30 jul. 2020.
} 
Figura 46 - alguns ideais do coaching em publicação do Instituto Brasileiro de Coaching.

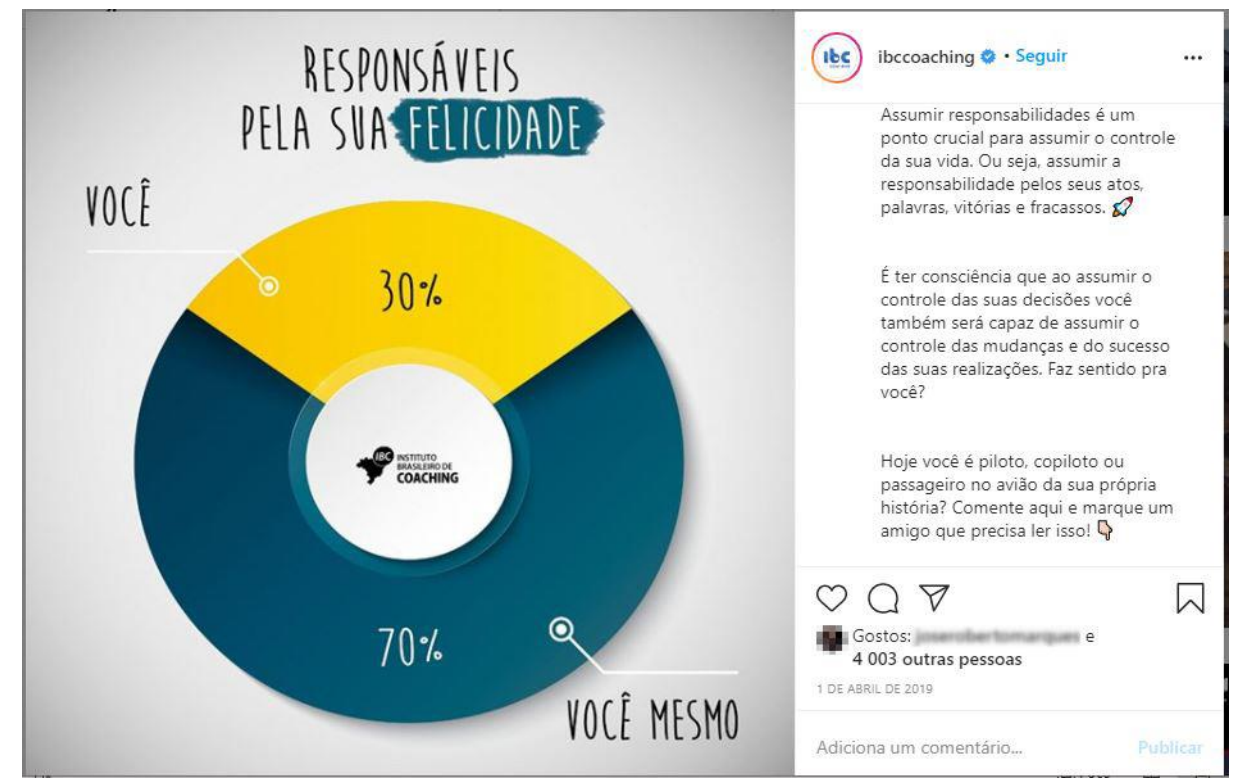

Fonte: print screen feito a partir do perfil pessoal da pesquisadora, com a versão desktop do Instagram.

De modo semelhante, a postagem da Sociedade Latino Americana de Coaching (figura 47) apela para a autorresponsabilidade do sujeito, como fica evidente na frase "a organização de sua vida, seu tempo e suas prioridades são pontos importantes para que você consiga atingir suas metas":

Figura 47 - publicação sobre autorresponsabilidade feita pela Sociedade Latino Americana de Coaching.

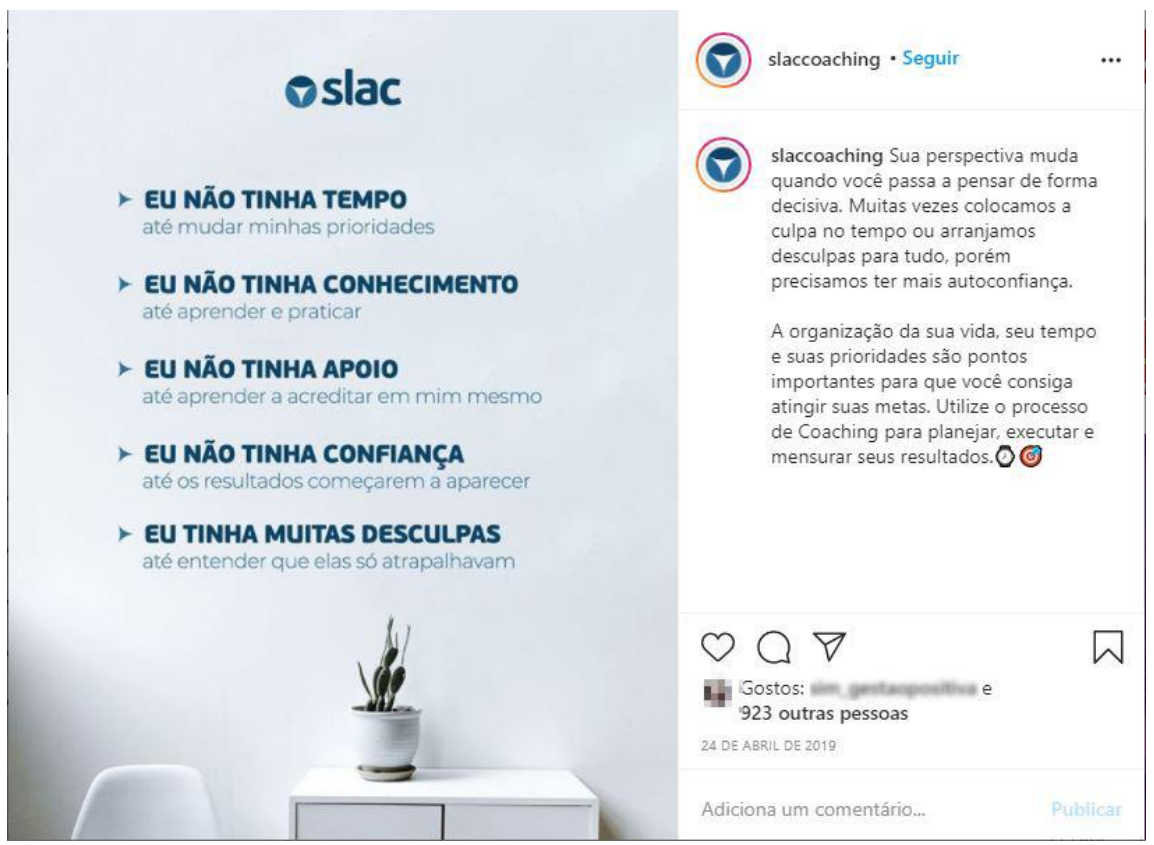

Fonte: print screen feito a partir do perfil pessoal da pesquisadora, com a versão desktop do Instagram. 
Dentre as postagens com mais curtidas e comentários nos perfis de Ana e Bia, prevalecem os autorretratos - ou selfies. De modo semelhante, os perfis de Duda e Fabi trazem fotografias nas quais a imagem do rosto delas é o destaque principal. Nesse sentido, a venda do serviço de coaching se dá por meio da imagem dessas pessoas, em uma dissolução entre pessoa física e jurídica: "na sociedade expositiva, cada sujeito é seu próprio objeto-propaganda; tudo se mensura em seu valor expositivo". (HAN, 2018, p. 31-32). Essa mistura entre vida íntima e vida profissional de certo modo aponta para uma confusão entre o self e suas autorrepresentações, como se os perfis pudessem de fato substituir os sujeitos representados.

A tentativa de adaptação das autorrepresentações às dinâmicas da rede também deve ser levada em consideração. No caso da escolha dos nomes e dos nomes de usuário dos perfis, por exemplo, os perfis de Ana, Bia e Fabi trazem a palavra-chave "coach de carreira" na categoria nome; nesse sentido, as três abdicaram de incluir seus nomes próprios em prol de uma palavra-chave, o que sugere a tentativa de categorização do perfil. Já na categoria nome de usuário, quatro perfis trazem, além do nome e do sobrenome do dono do perfil, a palavra "coach" - ou seja, abre-se mão da singularidade do nome próprio em prol do ajuste a uma categoria geral, "coach".

Em uma série de stories em formato de vídeo publicados por Bia, ela falou sobre a dificuldade de cumprir as exigências do Instagram e a necessidade de se adequar a elas para poder conquistar visibilidade na rede. Bia fez os Stories após um desafio autoimposto de realizar uma transmissão ao vivo (live) por dia, durante um mês inteiro em seu perfil:

Depois eu quero dividir com vocês o que eu aprendi fazendo live todos os dias, como é que é ter essa disciplina, não é fácil para quem está tentando ficar mais presente e consistente nas redes sociais, é um desafio, gente. Tem vezes que a gente não está a fim, mas, como tudo na vida, nem tudo é gostosinho. 'Ah, Bia, por que você faz isso?'. Eu gosto de me desafiar e aprender enquanto estou fazendo. (Bia, 2019, informação verbal) ${ }^{87}$

Ana também evidenciou seu esforço em fazer uma autorrepresentação alinhada às dinâmicas do Instagram em vídeos publicados em seus Stories, embora não possamos descartar que eles tenham sido feitos com o propósito de gerar proximidade com sua

\footnotetext{
${ }^{87}$ Falas transcritas de Stories no Instagram de Bia em formato de vídeo, publicados em maio de 2019. Conteúdo efêmero, com duração de 24 horas, que a autora não deixou armazenado em seu perfil.
} 
audiência. Em uma série de histórias feitas em seu quarto, durante a noite, em imagens escuras, ela afirmou:

Já em casa, de pijama, estava lendo as perguntas, tem um monte, um monte, de pergunta legal, mas vou responder amanhã, hoje vou deitar porque minha cabeça está dando uma reclamada, mas amanhã eu já vou acordar bem e a gente se conversa. (Ana, 2019, informação verbal $^{88}$

Embora não possamos reproduzir em detalhes o funcionamento da rede, pontuamos que sua interface, seus códigos e o encadeamento de signos de distintas naturezas, juntos, fornecem uma imersão dos usuários nesse ambiente. A rapidez das trocas, que ocorrem especialmente por reações, como cliques, curtidas e comentários breves, a possibilidade de saltar por diferentes postagens por meio de cliques em hashtags e menções a outros perfis e as atualizações constantes do feed levam a uma experiência característica da secundidade, sem muito tempo para reflexão. Nesse sentido, essa dinâmica voraz parece exigir do sujeito que se autorrepresenta um esforço em provocar reações em outros usuários em meio a uma série de estímulos concorrentes, enquanto, concomitantemente, precisa lidar com as características simbólicas que cada postagem.

O estímulo às interações também é recorrente nas postagens de todos os perfis analisados. Em geral, as legendas contam com perguntas e verbos no imperativo, como "marque" e "conte". Há ainda convocações para que os usuários enviem mensagens privadas. Se considerarmos as políticas de uso do Instagram, podemos afirmar que esses coaches têm noções sobre o funcionamento da rede e, munidos de tal informação, procuram gerar estímulos que resultem em interações e, consequentemente, em interpretantes alinhados a seus objetivos.

Pelo menos em dois perfis - no de Ana e no de Edi - identificamos o uso de postagens patrocinadas. Assim, além das publicações orgânicas em seus feeds, eles pagaram ao Instagram para fazer pelo menos um anúncio. Embora este não seja o foco de nossa investigação, o achado evidencia que os processos de autorrepresentação nesta rede também estão permeados por elementos que podem tanto estimular certos processos semiósicos - como o pagamento de anúncio, que garante mais visibilidade a determinadas postagens e perfis e, portanto, mais possibilidades de semiose -, quanto, em outros casos, diminuir as possibilidades de geração de sentidos - caso uma postagem orgânica não seja

\footnotetext{
${ }^{88}$ Falas transcritas de Stories no Instagram de Ana, publicados em abril de 2019. Conteúdo efêmero, com duração de 24 horas, que a autora não deixou armazenado em seu perfil.
} 
distribuída às conexões do perfil pelos mecanismos da rede, por exemplo, o signo não encontra intérpretes humanos e não é atualizado.

Recordamos, mais uma vez, que, de acordo com a Semiótica, os sentidos emergem da relação, na qual o signo atua como elemento mediador. Assim, considerando-se um perfil no Instagram como um conjunto de signos em relação, entendemos que ele faz a mediação entre as ideias que o coach deseja comunicar sobre si mesmo e sobre a sua atuação profissional e os possíveis intérpretes. O perfil, como autorrepresentação simbólica, é criado para produzir certos tipos de efeitos na audiência. Entretanto, no ambiente digital a autorrepresentação não se limita apenas às camadas das interfaces.

Para que a mensagem chegue a outras pessoas e gere interpretantes alinhados a seus propósitos, o sujeito que se autorrepresenta também precisa se esforçar para construir representações que produzam interpretantes na camada dos códigos da rede, pois esta possui regras e programações que determinam a visibilidade e o alcance de um perfil. Pensando no funcionamento do Instagram, podemos dizer que, à medida em que a rede registra curtidas, comentários e outras interações relacionadas a um perfil, ela gera interpretantes de que aquele perfil é relevante para as conexões dele e, assim, as atividades de tal perfil passam a ser mais distribuídas entre suas conexões. Consequentemente, quanto mais público o perfil alcança, mais possibilidades de semiose e mais possibilidades de gerar interpretantes alinhados aos propósitos traçados na criação da autorrepresentação. Esse processo não é linear, mas ocorre ao mesmo tempo, em distintas formas de representação interconectadas.

Não obstante, durante o processo de autorrepresentação, é preciso ainda contar com os elementos de acaso, uma vez que nunca há certeza se uma autorrepresentação vai gerar interpretantes e/ou que tipos de interpretantes ela vai provocar. Do ponto de vista da interface, a imprevisibilidade das interações entre os usuários é um fator importante, embora alguns hábitos estejam estabelecidos. Outrossim, a seleção algorítmica atua de modo opaco, sem que os usuários da rede tenham conhecimento de todas as suas dinâmicas e implicações. Nessa perspectiva, podemos afirmar que a ação sígnica no Instagram é permeada por atores humanos e elementos não-humanos. Por conseguinte, o desafio de se autorrepresentar no Instagram está em conjugar elementos simbólicos alinhados à experiência colateral dos possíveis intérpretes e elementos indiciais capazes de serem interpretados pela rede. 


\section{CONCLUSÃO}

Para encerrar este trabalho, retomamos a pergunta central que animou a nossa investigação. Nela, questionávamos de que modo a Semiótica de Charles S. Peirce poderia contribuir para o estudo das autorrepresentações em perfis em redes sociais digitais do ponto de vista do campo da Comunicação. Durante nossa trajetória de pesquisa, procuramos delinear caminhos para a abordagem das autorrepresentações a partir da discussão do conceito de signo, das categorias fenomenológicas peirceanas, do self semiótico e da semiose como centro do processo comunicacional.

Outrossim, complementamos a perspectiva semiótica com um olhar contemporâneo sobre as dinâmicas dos ambientes digitais, que incluiu explanações sobre a cibercultura, os processos participativos, os bancos de dados, a seleção algorítmica, os movimentos engendrados pelas redes, as políticas de uso e de dados do Instagram e o contexto socioeconômico no qual o fenômeno está inserido. Após este longo percurso, compartilhamos aqui algumas respostas, certos de que elas são falíveis e que darão origem a novas perguntas.

Em primeiro lugar, pontuamos que a Semiótica contribuiu para a ampliação das possibilidades de investigação do objeto ao oferecer definições lógicas dos processos de geração e compartilhamento de significados, permitindo-nos explorar as distintas camadas do fenômeno da autorrepresentação, ainda que de modo limitado, devido ao recorte e ao tempo disponível. Nesse sentido, entendemos que é impossível desvendar toda a complexidade das autorrepresentações em redes sociais se abordarmos apenas um de seus aspectos, como a relação emissor-receptor, ou se nos enforcarmos em uma só linguagem, como a visual. A perspectiva semiótica nos permitiu enumerar a multiplicidade de fatores interconectados na emergência das autorrepresentações no digital, evitando, assim, conclusões reducionistas sobre o fenômeno.

A definição triádica de signo peirceana aponta para o papel mediador dos signos nas trocas comunicacionais e, mais do que isso, evidencia que a ação dos signos, denominada por Peirce como semiose, ocupa o papel central da Comunicação, em detrimento do sujeito. O signo, ao mediar a relação entre o objeto (ou ideia que se deseja comunicar) e o interpretante (ou o intérprete humano, dependendo do fenômeno analisado), possibilita o partilhamento de sentidos. Isso trouxe implicações importantes para a nossa pesquisa, pois reconhecemos que o processo de geração de significados relacionado às autorrepresentações em perfis profissionais não pode ser compreendido de 
modo dissociado das mediações tecnológicas engendradas pela rede social Instagram. Ponderamos, entretanto, que a centralidade da semiose não exclui o sujeito do processo comunicacional. O que a Semiótica demonstra é que não existe apenas a semiose antropocêntrica. Se pensarmos, por exemplo, na ação de algoritmos, constatamos que, ao atuarem na seleção de informações como uma espécie de gatekeeper, eles afetam, direta e indiretamente, as trocas comunicacionais entre os sujeitos, ainda que a seleção algorítmica esteja limitada por conjuntos de regras definidas previamente por humanos responsáveis por configurá-los.

Conforme apontamos anteriormente, o estudo dos processos de autorrepresentação requer a discussão da subjetividade. Nessa perspectiva, discorremos sobre a noção semiótica de self enquanto símbolo, evidenciando, assim, que o sujeito emerge a partir de processos semioticamente mediados, como assinala Colapietro (2019). A abordagem semiótica do sujeito esclarece que o self é um agente comunicativo (COLAPIETRO, 2014) e, como tal, constitui-se a partir do outro. Em outras palavras, conclui-se que os processos comunicacionais fazem parte da ontologia do ser. A Teoria Semiótica também possibilitou a diferenciação entre os conceitos de eu e identidade. Com a consideração do self semiótico, observamos que o sujeito não pode ser resumido à uma autorrepresentação.

Do ponto de vista da Semiótica Peirceana, as autorrepresentações são identidades de um mesmo sujeito, ou seja, são identidades do self semiótico (WILEY, 1996). Assim, um sujeito pode ter distintas identidades ou autorrepresentações. O self não deve ser confundido com uma identidade, pois ele é uma entidade em constante desenvolvimento, enquanto a identidade está circunscrita a um contexto. Em outras palavras, embora a autorrepresentação faça parte em alguma medida do self, ela não é o self em sua totalidade.

Cabe acrescentar, ainda, que o self só pode se manifestar por meio de suas autorrepresentações, uma vez que, como esclarece Wiley (1996, p. 52), a identidade funciona como "ponte entre o self e o mundo". Ou seja, o self só pode se revelar e se comunicar por meio de processos mediadores operados por signos. Essa conceituação de self presente na Teoria Semiótica comprova o papel central que as autorrepresentações ocupam nos processos de comunicação e sociabilidade contemporâneos, em especial aqueles situados no ambiente digital.

Uma de nossas inquietações no início da pesquisa estava relacionada à pergunta: o sujeito é o mesmo dentro e fora do ambiente digital? Nossa resposta é: depende. Ora, 
como já afirmamos, a autorrepresentação faz parte em alguma medida do self. Por outro lado, o sujeito fora do ambiente digital, enquanto self semiótico, é muito mais complexo do que qualquer representação. Posto que o self só pode se comunicar com o mundo por meio de signos, como postula Peirce, está claro que ele não pode ser completamente dissociado de suas representações. Cabe lembrar, ainda, que as representações da subjetividade no contexto digital são permeadas por processos alheios à ação do sujeito, como a coleta e o tratamento de dados e a seleção feita por algoritmos. Nesse sentido, a tendência à padronização de identidades digitais, estimulada por plataformas por meio da imposição de categorias às quais as representações devem se adequar, entre outras estratégias mercadológicas, pode levar a impactos na constituição dos sujeitos que ultrapassam os limites do ambiente virtual, como pontua Floridi (2014). Entendemos que essa perspectiva merece o aprofundamento em pesquisas com enfoque transdisciplinar, capazes de integrar outros campos do conhecimento ante a complexidade do tema.

Ao abordarmos as autorrepresentações no ambiente digital a partir das doutrinas peirceanas do Sinequismo (princípio da continuidade entre todas as coisas e da tendência à aquisição de hábitos) e do Tiquismo (a existência do acaso e da aleatoriedade no universo), reiteramos nossa constatação de que não se pode separar o fluxo semiótico entre humanos e elementos não-humanos, uma vez que a continuidade entre esses elementos, considerando o acaso presente nas ações, é que dá origem a novos significados. A semiose no ambiente digital ocorre a partir de diversas camadas interconectadas que impossibilitam o controle total de seus possíveis significados por parte dos sujeitos que buscam se autorrepresentar, embora possa haver tentativas de direcionar a geração de interpretantes alinhados aos propósitos de tal autorrepresentação.

Nessa perspectiva, o acaso atua como elemento de primeiridade fenomenológica e funciona como um ícone que nutre o símbolo (em nosso caso os perfis profissionais no Instagram) de novas possibilidades interpretativas. Já as interações que ocorrem na rede, tais como curtidas e comentários, atuam como elementos de secundidade, atualizando o signo e gerando tendências que se refletem na programação dos algoritmos e, consequentemente, levarão à configuração de padrões de distribuição dos conteúdos na rede.

A autorrepresentação em ambientes digitais, especialmente na rede social Instagram, implica que os processos de normatização por algoritmos, de um lado, e o acaso presente nas interações entre usuários, de outro, deslocam o poder e o controle dos processos de autorrepresentação. Em outras palavras, o sujeito que se autorrepresenta tem 
ferramentas para operar sobre as escolhas de representação - definindo, por exemplo, alguns elementos de seu perfil no Instagram, como fotos e textos -, mas tem pouco poder sobre como essa representação será interpretada. Os mecanismos de "personalização" e "bolha dos filtros" descritos por Pariser (2012), junto com as políticas e dinâmicas da rede, limitam o controle da autorrepresentação pelo usuário.

Ao analisar os perfis profissionais de coaches de carreiras no Instagram, constatamos que o fenômeno da autorrepresentação no ambiente digital é marcado por distintas formas de representação. Considerado como símbolo ou conjunto de signos em relação, o perfil profissional no Instagram é criado com o objetivo de gerar certos efeitos. $\mathrm{Ou}$ seja, as pessoas buscam se autorrepresentar por meio de perfis para satisfazer determinadas intenções. Entretanto, para alcançar esses propósitos é necessário mobilizar diferentes signos, de acordo com os repertórios e experiências da audiência, e, além disso, adaptar constantemente o perfil às dinâmicas da rede.

Assim, na camada da interface, na qual os signos do perfil emergem nas telas de smartphones e computadores e chegam aos possíveis intérpretes, constatamos que os coaches buscaram mobilizar elementos simbólicos relacionados à realização de sonhos, ao sucesso pessoal e material e ao relato de experiências de vida, em um movimento alinhado ao "capitalismo artista" descrito por Lipovetsky e Serroy (2015).

Ainda na camada das interfaces, há um esforço no sentido de provocar reações em outros usuários, que se traduz no uso constante de perguntas, do pronome "você" e de verbos no modo imperativo como "marque", "comente" e "conte". Entendemos, com Recuero (2012), que as interações ajudam a gerar capital social ao dono do perfil, contribuindo, assim, para os propósitos que desejam ser comunicados. Entretanto, além da tentativa de mobilizar as emoções dos usuários, identificamos que essa estratégia está diretamente relacionada às políticas de dados e de uso do Instagram, uma vez que a rede identifica tais interações como indícios de que o perfil tem relevância, o que afeta diretamente o modo como seus conteúdos serão distribuídos às suas conexões. Assim, um perfil que consiga gerar mais reações ganha mais visibilidade e, por conseguinte, amplia as possibilidades de semiose e de geração de sentidos. O contrário também é verdadeiro: uma autorrepresentação feita em um perfil que não alcance outros usuários terá suas chances de gerar interpretantes limitadas e, portanto, corre o risco de não alcançar seus objetivos.

Nos perfis analisados, considerando-se as dinâmicas e o ambiente do Instagram, pode-se afirmar que as hashtags são usadas em estratégias de representação que operam 
em diferentes domínios fenomenológicos. Assim, ao mesmo tempo em que conectam conteúdos e funcionam como elementos de secundidade, as hashtags também atuam em domínio simbólico, ao mobilizarem hábitos convencionados socialmente, como o uso da hashtag \#tbt, associada a conteúdos do passado que trazem boas lembranças. O mesmo pode ser afirmado em relação às menções a outros perfis, uma vez que, além de fazerem conexão direta entre dois perfis, funcionando, assim, como índices, elas carregam uma carga simbólica. Deste modo, ao mencionar o perfil de uma figura pública em suas publicações, avaliamos que alguns coaches buscaram se apropriar dos valores associados a tal perfil, em uma tentativa de transferi-los à sua autorrepresentação.

A partir dos conceitos semióticos de signo, semiose e experiência colateral, constatamos ainda que o estudo das autorrepresentações em redes sociais digitais não pode ser dissociado do contexto socioeconômico e cultural e dos sujeitos relacionados ao processo. Conforme expomos no primeiro capítulo, a Semiótica postula que os sentidos emergem da relação. Nessa perspectiva, os processos participativos e os elementos de acaso inerentes a essas trocas evidenciam a necessidade de novas investigações que incluam o estudo dos interpretantes, considerando os intérpretes e os significados que emergem nas trocas.

Por fim, concluímos que as autorrepresentações em ambientes digitais estão intrinsecamente atreladas a fluxos semióticos de distintas naturezas, em dinâmicas que se transformam continuamente, de modo muitas vezes desconhecido pelos sujeitos que participam do processo. Diante da complexidade e do dinamismo do objeto, reconhecemos que a única certeza é que é impossível prever e controlar todos os sentidos gerados e compartilhados a partir das autorrepresentações em redes sociais da internet. 


\section{REFERÊNCIAS}

AIRFLUENCERS. Airfluencers Score, 2019. Disponível em:

$<$ http://help.airfluencers.com/pt-BR/articles/2118089-airfluencers-score $>$. Acesso em:

20 abr. 2019.

ALMEIDA, C. Fundamentos peirceanos: a dimensão diagramática do faneron.

Intercom - Sociedade Brasileira de Estudos Interdisciplinares da Comunicação. XXXV Congresso Brasileiro de Ciências da Comunicação - Fortaleza, CE - 3 a 7/9/2012.

Disponível em: < http://www.intercom.org.br/papers/nacionais/2012/resumos/R7-06251.pdf $>$. Acesso em: 10 ago. 2019.

. Os sistemas das mídias sociais: emergência, circunstância e movimento.

TECCOGS: Revista Digital de Tecnologias Cognitivas, v. 8, p. 88-113, 2013.

Disponível em: < http://www4.pucsp.br/pos/tidd/teccogs/dossies/2013/edicao_8/1-

sistemas_midias_sociais_emergencia_circunstancia_movimento-candida_almeida.pdf $>$. Acesso em: 10 set. 2019.

ALZAMORA, G.C.; BICALHO, L.A.G. A representação do Impeachment Day mediada por hashtags no Twitter e no Facebook: semiose em redes híbridas. Interin (UTP), v. 21, p. 100-121, 2016. Disponível em: <

https://seer.utp.br/index.php/i/article/view/467 >. Acesso em: 11 out. 2019.

ANANNY, M. Towards na Ethics of Algorithms: convening, obervation, probability and timeliness. Science, Technology \& Human Values, 1-25, 2015. Dosponível em: < https://journals.sagepub.com/doi/10.1177/0162243915606523 >. Acesso em: 2 set. 2019.

BERGMAN, M. C.S. Peirce on Interpretation and Collateral Experience. Signs International Journal of Semiotics, Dinamarca, vol. 4, p. 134-161, 2010.

BESSA, A. R. Influenciadores em redes sociais digitais: uma análise aplicada ao Instagram: o processo de desenvolvimento do ambiente e das possibilidades interativas em comunicação. 2018. Dissertação (Mestrado em Ciências da Comunicação). Escola de Comunicações e Artes da Universidade de São Paulo. São Paulo, 2018.

10.11606/D.27.2019.tde-22022019-144714. Disponível em: < http://www.teses.usp.br/teses/disponiveis/27/27154/tde-22022019-144714/pt-br.php>. Acesso em: 16 mar. 2019.

boyd, d. Faceted Id/entity: Managing representation in a digital world. Dissertação. (in partial fulfillment of the requirements for the degree of Master of Science in Media Arts and Sciences). Massachusetts Institute of Technology, 2002.

boyd, d.; ELLISON, N. Social Network Sites: definition, history, and scholarship. In: Journal of Computer Mediated Communication, vol 13, nº 1, pp. 210-230, 2007. Disponível em: <https://doi.org/10.1111/j.1083-6101.2007.00393.x.>. Acesso em: 10 fev. 2019.

COLAPIETRO, V. Peirce e a Abordagem do Self: Uma Perspectiva Semiótica Sobre a Subjetividade Humana. São Paulo: Intermeios, 2014. 
Vincent Colapietro e a abordagem semiótica da subjetividade, 2019.

[Entrevista por e-mail concedida a Rebeka Figueiredo da Guarda e Anderson Vinícius Romanini]. 30 abr. 2019. Disponível no Apêndice A desta dissertação.

COULDRY, N.; MEJIAS, U.A. Data Colonialism: Rethinking Big Data's Relation to the Contemporary Subject. Television \& New Media, v. 20, n. 4, pp. 336-349, 2019. Disponível em: $<$ https://doi.org/10.1177/1527476418796632>. Acesso em: 20 mai. 2019.

DIJCK, José van; POELL, Thomas; WAAL, Martijn de. The Platform Society: public values in a connective world. Oxford: Oxford University Press, 2018.

EMOJI. In: Lexico by Oxford. Disponível em: $<$ https://www.lexico.com/definition/emoji $>$. Acesso em: 20 jul. 2020.

ESPOSITO, J. Synechism: the Keystone of Peirce's Metaphysics. In M. Bergman \& J. Queiroz (Eds.), The Commens Encyclopedia: The Digital Encyclopedia of Peirce Studies. New Edition. Pub. 130510-1417a, 2005. Disponível em: < http://www.commens.org/encyclopedia/article/esposito-joseph-synechism-keystonepeirce $\%$ e2\%80\%99s-metaphysics>. Acesso em: 17 dez. 2019.

FANTONI, A. Autorrepresentação de adolescentes porto-alegrenses no Instagram. Dissertação de Mestrado. Programa de Pós-Graduação em Comunicação Social. Pontifícia Universidade Católica do Rio Grande do Sul. Rio Grande do Sul, 2017. Disponível em: < http://repositorio.pucrs.br/dspace/handle/10923/10701 >. Acesso em: 20 abr. 2019.

FEBRACIS. O que é coaching, 2019a. Disponível em: < https://febracis.com/o-que-ecoaching/>. Acesso em: 15 mai. 2019. mai. 2019.

Sobre, 2019b. Disponível em: < https://febracis.com/sobre/ >. Acesso em: 15

FLORIDI, L. A Proxy Culture. Philosophy \& Technology. Holanda, v. 28, pp. 487490, 2015. Disponível em: <https://doi.org/10.1007/s13347-015-0209-8>. Acesso em: 10 fev. 2019.

The Fourth Revolution: How the Infosphere is Reshaping Human Reality. Oxford: Oxford University Press, 2014.

GARRA, M. S. M. O self semiótico: desenvolvimento interpretativo da identidade como um processo dramático. Tese de Doutorado em Psicologia do Desenvolvimento. Universidade Federal do Rio Grande do Sul. Rio Grande do Sul, 2006. Disponível em: $<$ http://hdl.handle.net/10183/7783>. Acesso em: 20 abr. 2019.

GILLESPIE, T. A relevância dos algoritmos. Trad.: Amanda Jurno. Parágrafo, São Paulo, Brasil, v. 6, n. 1, p. 95-121, jan./abr. 2018. 
. The relevance of algorithms. In: Gillespie, T.; Boczkowski, P. J.; e Foot, K.A.

(Org.). Media Technologies: Essays on Communication, Materiality, and Society, 2014.

GOFFMAN, E. A representação do eu na vida cotidiana. $10^{\mathrm{a}}$ ed. Trad.: Maria Célia Santos Raposo. Petrópolis: Vozes, 2002.

HALL, S. A identidade cultural na pós-modernidade. $11^{\mathrm{a}}$ ed. Trad.: Tomaz Tadeu da Silva; Guacira Lopes Louro. Rio de Janeiro: DP\&A, 2006.

HAN, B-C. Sociedade da Transparência. $2^{\mathrm{a}}$ reimpressão 2018. Trad.: Enio Paulo Giachini. Petrópolis: Vozes, 2017.

IASBECK, L.C.A. Método semiótico. In: Métodos e Técnicas de Pesquisa em Comunicação. Org. Jorge Duarte; Antonio Barros. 2. ed. 9. Reimpr. São Paulo: Atlas, 2017.

IBC. O que é coaching, 2019b. Disponível em:

$</ /$ www.ibccoaching.com.br/portal/coaching/o-que-e-coaching/>. Acesso em: 14 abr. 2019.

Sobre o IBC, 2019a. Disponível em: <https://www.ibccoaching.com.br/sobreo-ibc/o-ibc/.>. Acesso em: 14 abr. 2019.

IBRI, I. A. Kósmos noetós: a arquitetura metafísica de Charles S. Peirce. São Paulo: Paulus, 2015.

ICF. Sobre a ICF, 2019. Disponível em: <https://www.icfbrasil.org/icf/sobre-a-icf $>$. Acesso em: 15 mai. 2019.

IGT. 2019. Disponível em:< https://igtcoaching.com.br/ >. Acesso em: 15 mai. 2019.

INSTAGRAM. Introducing Instagram Explore, Photo Maps and More, 2012.

Disponível em: $<$ https://about.instagram.com/blog/announcements/introducinginstagram-explore-photo-maps-more $>$. Acesso em: 20 mai. 2020.

. Introducing Photos of you, 2013. Disponível em: $<$ https://instagrampress.com/ru/blog/2013/05/02/introducing-photos-of-you/>. Acesso em: 20 mai. 2020.

See the moments you care about first, 2016a. Disponível em:

$<$ https://instagram-press.com/blog/2016/03/15/see-the-moments-you-care-about-first/. Acesso em: 20 mai. 2020.

Introducing Instagram Stories, 2016b. Disponível em: $<$ https://instagrampress.com/ru/blog/2016/08/02/introducing-instagram-stories/>. Acesso em: 20 mai. 2020.

Now you can follow hashtags on Instagram, 2017. Disponível em:

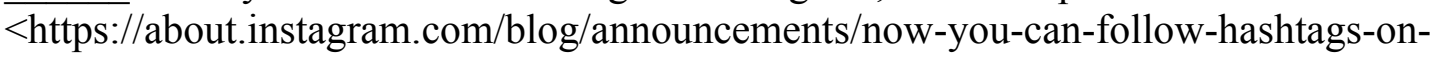
instagram>. Acesso em: 20 mai. 2020. 
. Apresentamos hashtags e links na biografia do perfil, 2018. Disponível em: < https://about.instagram.com/pt-br/blog/announcements/introducing-hashtag-and-profilelinks-in-bio>. Acesso em 12 out 2019.

Instagram Data Policy, 2019a. Disponível em:

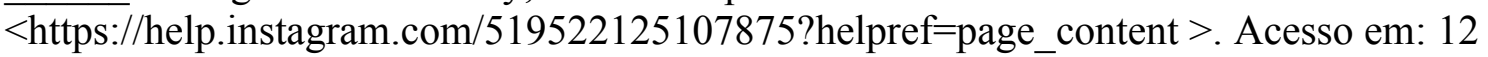
out. 2019.

Creators, 2019b. Disponível em:

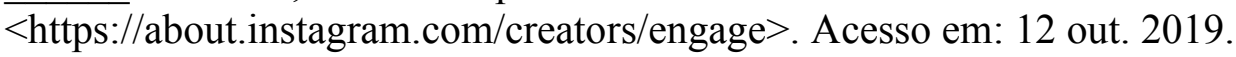

JENKINS, H.; FORD, S.; GREEN, J. Cultura da conexão: criando valor e significado por meio da mídia propagável. Trad.: Patricia Arnaud. São Paulo: Aleph, 2014

JUST, N.; LATZER, M. Governance by Algorithms: Reality Construction by Algorithmic Selection on the Internet. Media, Culture \& Society, Volume 39, Número 2, páginas 238-258, 2016.

KARHAWI, I. S. De blogueira à influenciadora: motivações, ethos e etapas profissionais na blogosfera de moda brasileira. Tese (Doutorado em Ciências da Comunicação) - Escola de Comunicações e Artes da Universidade de São Paulo. São Paulo, 2018. DOI: 10.11606/T.27.2018.tde-17092018-163855. Disponível em: $<$ http://www.teses.usp.br/teses/disponiveis/27/27152/tde-17092018-163855/ptbr.php>.Acesso em: 19 mar 2019.

KILLINGSWORTH, S. And the Word of the Year Is... In: The New Yorker. 19 nov 2013. Disponível em: < https://www.newyorker.com/culture/culture-desk/and-the-wordof-the-year-is $>$. Acesso em: 20 jul 2019.

KIRKPATRICK, D. The Facebook Effect: The Inside Story of the Company that is Connecting the World. New York: Simon and Schuster, 2010.

LÉVY, Pierre. Cibercultura. Trad.: Carlos Irineu da Costa. Rio de Janeiro: Editora 34, 1999.

LIMA, A.S. Quem sou eu: autorrepresentações de travestis no Orkut. Dissertação de Mestrado em Arte e Cultura Visual. Universidade Federal de Goiás, 2009.

Disponível em: < https://repositorio.bc.ufg.br/tede/handle/tde/2818>. Acesso em: 20 abr. 2019.

LIPOVETSKY, G.; SERROY, J. A estetização do mundo: Viver na era do capitalismo artista ( $1^{a}$ ed.). Trand.: Eduardo Brandão. São Paulo: Companhia das Letras, 2015.

LOPES, M.I.V. Pesquisa em Comunicação. 12 ed. São Paulo: Edições Loyola, 2014.

. Reflexividade epistêmica na pesquisa empírica em Comunicação. In: Conexão pós: diálogos e intersecções na pesquisa discente (pp.12-26). São Paulo: Casa Editora ECA-USP, 2018. 
MANOVICH, L. Notes on Instagrammism and mechanisms of contemporary cultural identity (and also photography, design, Kinfolk, kpop, hashtags, mise-en-scène, and состояние). In: MANOVICH, L. Instagram and Contemporary Image, 2016.

Disponível em: $<$ http://manovich.net/content/04-projects/094-notes-on-instagrammismand-mechanisms-of-contemporary-cultural-identity/notes-on-instagrammism.pdf $>$. Acesso em: 03 mai 2019.

. O Banco de Dados. In: The Language of New Media. Trad.: Camila Vieira. Revista Eco Pós, UFRJ, v.18, n.1, 2015. Disponível em: $<$ https://revistas.ufrj.br/index.php/eco_pos/article/view/2366>. Acesso em: 12 out. 2018.

The Language of New Media. Cambridge: Mit Press, 2001.

MUSSO, P. A filosofia da rede. In. Tramas da Rede: novas dimensões filosóficas, estéticas e políticas da comunicação. Org. André Parente. Porto Alegre: Sulina, 2013.

NÖTH, W. Charles S. Peirce's Theory of Information: A Theory of the Growth of Symbols and of Knowledge. Cybernetics and Human Knowing. Vol. 19, nos. 1-2, p. 137-161, 2013.

. Máquinas semióticas. Galáxia, São Paulo, n. 1, p. 51-73, 2001. ISSN 19822553. Disponível em: < https://revistas.pucsp.br/galaxia/article/view/1057/694 >. Acesso em: 3 mar. 2020.

O'NEIL, C. Weapons of math destruction: how big data increases inequality and threatens democracy. New York: Crown Publishers, 2016.

PARISER, E. O filtro invisível: O que a internet está escondendo de você. Trad.: Diego Alfaro. Rio de Janeiro: Zahar, 2012.

PEIRCE, C. S. Quest of Quest. MS [R] 655, 1910. 'Normative Science'. Term in M. Bergman \& S. Paavola (Eds.), The Commens Dictionary: Peirce's Terms in His Own Words. New Edition. Disponível em: < http://www.commens.org/dictionary/term/normative-science $>$. Acesso em: 20 mai. 2020 .

Semiótica. $3^{\mathrm{a}}$ reimp. da $4^{\mathrm{a}}$ ed. de 2010. Trad.: José Teixeira Coelho Neto. São Paulo: Perspectiva, 2017.

The Basis of Pragmaticism. MS [R] 283, 1906. Disponível em: < http://www.commens.org/dictionary/term/sign>. Acesso: 10 jul. 2019.

The Collected Papers of Charles Sanders Peirce. Electronic Edition. Vols. IVI. HARTSHORNE, C; WEISS, P. (ed.). Cambridge, MA: Harvard University Press (1931-1935), 1994.

The Collected Papers of Charles Sanders Peirce. Electronic Edition. Vols. VII-VIII. BURKS, A. W. (ed) Cambridge, MA: Harvard University Press (1958), 1994. 
. How to Make Our Ideas Clear, 1878. Disponível em: $<$ https://goo.g1/YP9tEW >. Acesso em: 20 mar. 2018.

On The Bearing of Esthetics and Ethics upon Logic. On The Definition of Logic. MS L 75. 363-364. Disponível em: < https://arisbe.sitehost.iu.edu/menu/library/bycsp/L75/ver1/175v1-05.htm\#topofpage>. Acesso em: 28 abr. 2018.

On The Bearing of Esthetics and Ethics upon Logic. On The Definition of Logic. MS L75.143-147. Disponível em:

$<$ https://arisbe.sitehost.iu.edu/menu/library/bycsp/L75/ver1/175v1-05.htm\#topofpage $>$. Acesso em: 28 abr. 2018.

The Fixation of Belief, 1877. Disponível em: < https://goo.gl/drXPPp $>$. Acesso em: 20 mar. 018.

The Law of Mind. The Monist, Volume 2, Issue 4, p. 533-559, 1 jul. 1892. Disponível em: <https://doi.org/10.5840/monist18922434>. Acesso em: 17 abr. 2019.

PISANI, F.; PIOTET, D. Como a web transforma o mundo: a alquimia das multidões. Trad.: Gian Bruno Grosso. São Paulo: Editora Senac São Paulo, 2010.

PRIMO, A. Interações Mediadas e Remediadas: Controvérsias entre as utopias da cibercultura e a grande indústria midiática. In. Interações em Rede. Org. Alex Primo. Porto Alegre: Sulina, 2016.

RECUERO, R. A conversação em rede: comunicação mediada pelo computador e redes sociais na Internet. Porto Alegre: Sulina, 2012.

ROMANINI, V. A Contribuição de Peirce para a Teoria da Comunicação. CASA: Cadernos de Semiótica Aplicada, v. 14, n.1, p. 13-56, 2016. Disponível em:

$<$ https://periodicos.fclar.unesp.br/casa/article/view/8082>. Acesso em: 10 mar. 2018.

Semiótica Minuta: Especulações sobre a gramática dos signos e da comunicação a partir da obra de CS Peirce. Tese de Doutorado em Ciências da Comunicação - Escola de Comunicações e Artes da Universidade de São Paulo. São Paulo, 2006. DOI: 10.11606/T.27.2006.tde-30042009-130918.

SANTAELlA, L. A Teoria Geral dos Signos: Como as linguagens significam coisas. São Paulo: Editora Pioneira, 2000a.

Chaves do Pragmatismo Peirceano nas Ciências Normativas. Cognitio, São Paulo, ano 1, n. 1, p. 94-101, $2^{\circ}$ Sem. 2000 b.

. Corpo e comunicação: sintomas da cultura. São Paulo: Paulus, 2004a. 2008. . Epistemologia Semiótica. Cognitio, São Paulo, v.9, n.1, p.93-110, jan./jun. 
. O Método Anticartesiano de C. S. Peirce. São Paulo: Editora UNESP, $2004 b$.

O que é semiótica. São Paulo: Editora Brasiliense, 1994.

Os Conceitos Anticartesianos do Self em Peirce e Bakhtin. Cognitio, São Paulo, v. 7, n. 1, p. 121-132, jan./jun. 2006.

Os Significados Pragmáticos da Mente e o Sinequismo em Peirce. Cognitio, São Paulo, n. 3, p. 97-106, nov. 2002.

SANTAELLA, L. NÖTH, W. Comunicação e Semiótica. São Paulo: Hacker Editores, 2004.

Imagem: cognição, semiótica, mídia. São Paulo: Iluminuras, 2012.

SBC. Career Coaching, 2019c. Diponível em: < https://www.sbcoaching.com.br/careercoaching >. Acesso em: 14 abr. 2019.

O que é coaching, 2019b. Disponível em: $<$ https://www.sbcoaching.com.br/oque-e-coaching)>. Acesso em: 14 abr. 2019.

Quem somos, 2019a. Disponível em: $<$ https://www.sbcoaching.com.br/quemsomos>. Acesso em: 14 abr. 2019.

SELF. In: Oxford Dictionaries. Oxford: Oxford University Press. Disponível em: $<$ https://en.oxforddictionaries.com/definition/self>. Acesso em: 18 abr. 2019.

SELFIE. In: Oxford English Dictionary (OED). Oxford: Oxford University Press. Disponível em: $<$ https://www.oed.com/view/Entry/390063?redirectedFrom=selfie $>$. Acesso em: 20 jul 2020.

SLAC. Nossa História, 2019a. Disponível em: < https://www.slacoaching.com.br/institucional/nossa-historia $>$. Acesso em: 15 mai. 2019.

. O que é Coaching de Carreira, 2019c. Disponível em: <

https://www.slacoaching.com.br/artigos-do-presidente/o-que-e-coaching-de-carreira>. Acesso em: Acesso em: 15 mai. 2019.

O que é Coaching, 2019b. Disponível em: $<$ https://www.slacoaching.com.br/oque-e-coaching $>$. Acesso em: 15 mai. 2019.

SODRÉ, M. As estratégias sensíveis: afeto, mídia e política. Petrópolis: Vozes, 2006.

WAAL, C. D. Science beyond the self: Remarks on Charles S. Peirce's social epistemology. Cognitio, São Paulo, v. 7, n. 1, p. 149-163, jan./jun. 2006. Disponível em:

$<$ https://www.academia.edu/28336163/Science_Beyond_the_Self_Remarks_on_Charle s_S_Peirces_Social_Epistemology >. Acesso em: 15 mai. 2019. 
WAAL, C. D. Sobre Pragmatismo. Trad.: Cassiano Terra Rodrigues. São Paulo: Edições Loyola, 2007.

WILEY, N. O self semiótico. Trad.: Luiz Paulo Rouanet. São Paulo: Edições Loyola, 1996. 


\title{
APÊNDICE A - Vincent Colapietro e a abordagem semiótica da subjetividade
}

\author{
Entrevista concedida por Vincent Colapietro, via e-mail, em inglês, a Rebeka
} Figueiredo da Guarda e Anderson Vinicius Romanini, em 30 de abril de 2019.

Rebeka Figueiredo and Vinicius Romanini: Semiotics is a general and formal theory and Peirce strove to remove it from any form of psychologism. However, as you point out in Peirce's Approach to the Self, this does not exclude the subject from the semiosis process. In what way "does the semiotic exploration of human subjectivity extend the boundaries of Semiotics," as you argue?

Vincent Colapietro: Part of my inspiration derives from Eco's response to Kristeva's position. While Julia Kristeva aligns her account of signs to a theorizing of the subject, Eco opposes this move - and he appeals to Peirce as a way of eliminating consideration of the subject. My main point in this chapter is that, from a Peircean perspective, this is all too hasty and unqualified. At a certain point, consideration of conscious and deliberative agency enters into the Peircean theory of signs. It does so most fully and explicitly in the third branch of semeiotic (the branch called at times "speculative rhetoric" and at other times "methodeutic"). There can be semiosis with human consciousness or agency, but at a certain point in some contexts the theorist must take account of the conscious and conscientious sign-using agent (e.g., the context of scientific inquiry beyond its most rudimentary stages). There is sign-activity in which the agency of the sign itself does not require any additional agent (the sunflower turning toward the sun or crystals forming would be CSP's own examples of such sign-activity). There are however instances of sign-activity in which the agency of the sign is joined by the agency of a sign-using animal (e.g., the geologist who is interpreting the significance of a fossil - (1) the formation of a fossil is in Peirce's sense an instance of semiosis, it does not depend for either its being or its significance on the act of the interpreter and (2) the process of interpreting the significance of this geological trace, a process conducted by a conscious and, in many cases, deliberative agent. If a general theory of signs is to serve as a framework for providing a normative theory of inquiry or science, that theory must, at some point, include a theory of subjectivity, consciousness, and agency. Semiosis is primordial, while sign-using agents such as human organisms are derivative (they derive or evolve out of simpler processes). Peirce's emphasis on the agency of the sign itself, in 
the most basic forms of semiosis, ought not to make us overlook his recognition of, say, scientists as sign-using and indeed symbol-making powers who emerge out of more rudimentary forms of semiosis. The most general definition of sign makes no reference to subjectivity or consciousness. But there are specific instances where the reference to conscious and deliberative subjects and agents is unavoidable; beyond being unavoidable, it is critical to consider such subjects and agents. How can one make sense out of science without any reference to scientists, that is, to individuals who exemplify a self-conscious, self-critical, and self-controlled use of signs and especially symbols? Yes, these are individuals who only come to be in the context of community and, yes, the community itself is dependent on the consolidation of sign-uses at a level not originally involving self-conscious and self-critical agents; but such agents manifestly emerge from simpler processes of semiosis.

RF/VR: You point out that for Peirce the self is a communicative agent, not a private sphere. What contributions could this concept bring to the field of communication?

VC: This actually works both ways. On the one side, theories of communication can be deployed to flesh out what Peirce implies regarding human subject as a communicative agent. On the other side, his own theory of signs - especially his accounts of the interpretants of signs - provide us with an implicit portrait of communicative agency. This however needs to be made explicit. Communication is a process in which the generation of interpretants in their complex interaction - specifically, the generation of emotional, energetic, and "logical" interpretants in their complex interaction - helps us to understand what communication is, both in its simpler and more complex forms. CSP's contribution to the field of communication should, thus, begin here: tracing the implications of his theory of interpretants (not just in reference to his classification of emotional, energetic, and "logical" interpretants but also in reference to the classification of immediate, actual, and normative). Peirce's theory of signs contributes more to the theory of communication, but I am inclined to suppose this is the most fruit place to begin tracing the implications of his theory for an understanding of communication.

RF/VR: Today, hundreds of millions of people around the world use social networks sites to construct representations of themselves. We know that many data included in these digital environments become perennial and can be used in different contexts. In addition, 
people spend more and more hours connected to digital environments. Considering this, would technology-mediated communications and the transformation of personal experience into digitized data lead to changes in the self, insofar as it is understood as a sign? If so, in what way?

VC: The emergence and development of subjectivity are complexly mediated processes. The self or subject is not only a sign-using agent but also itself a sign in process of development. The emphasis on language needs to be broadened to include the entire range of symbols on which humans rely. Our reliance on symbols is not primarily one on external means of communication or reflection. This reliance is rather constitutive: these symbols are integral to our being and, as a result, are constitutive of who we are. That is, symbols are not principally external means, but rather internal or constitutive features of our subjectivity and agency. Language is as much in us as we are in it; and it is in us because we are of it. What is true of a natural language can be equally true of various forms of technologically. Our relationship to the world is a semiotically mediated relationship: we always think in signs and we come to be one with the signs on which we rely (they are not external means, but constitutive features of our semiotic consciousness). So, too, our relationship is technologically mediated and it is so mediated in a way that is inseparable from semiotic mediation. All of this points to forms of subjectivity and identity undreamt before the inventions and innovations of the digital age. The self is not in place, picking up signs and tools to use. The self comes to be in its reliance on signs and tools, so much so that these signs and tools are constitutive of who and what the self (or subject) is. [John Dewey calls language "the tool of tools," and sees tools themselves as a kind of language.]

RF/VR: Since Peirce repudiates the Cartesian point of view and points to the decentralization of the subject, what are the implications of this decentering of the subject for our understanding of the multitude of different digital profiles held by a same person as she uses different social media (Facebook, Linkedin, Instagram etc)

VC: The fragmented and decentered subject possesses still, to some extent, a functional unity. For some purposes, these various personae can be seen as different facet of the same process, even if the process is open-ended and self-altering. Is the unity of the "I"an utter fiction or is to, in certain contexts, at least, a being to which we can responsibly or 
accurately ascribe a unity of functioning? I incline toward a view of the human subject wherein functional unity becomes an empirical or experimental question (Do all of these apparently disparate or disjoined identifies add up, in some respects, for some purposes, to a system or network having the capacity to act or function as a unity?).

RF/VR: You affirm that "The subject, in our sense of the term, is a deeply divided and culturally overdetermined being; and, moreover, a historical and incarnate being. Furthermore, whatever degree of freedom and consciousness the subject achieves, his life is essentially dramatic, and his possessions are radically insecure. "(Colapietro, p.83-84, translation from the Brazilian edition). This passage seems to approximate the subject's semiotic approach to the Marxist approach, although in the latter, there is a focus on the issue of context to the detriment of the subject's agency. How could we differentiate the semiotic approach from the Marxist? Can we say that Peirce's approach would also be superior to the understanding of the self in relation to the Marxist, as you argued in relation to estructuralism? Why?

VC: While there are social constraints and determination, they are of such a nature that they do not destroy or preclude genuine agency. Anthony Giddens works out the details of a theory in which social structures and human agency are seen as complementary rather than exclusive. From a Peircean perspective, one might do something analogous. This would run counter to Marxism, as it is ordinarily understood, but Marx might himself have been, in this regard, between than Marxists (that is, his account of history might allow more room for agency than is ordinarily appreciated by his "followers").

RF/VR: Peirce was concerned with terminology, with the choice of words he used in his studies. In Brazil, the translation of Peirce's Approach to the Self has maintained the word 'self' in English, although throughout the text the word 'subject' is also used. What are the differences between self, subject and identity? Why use the word 'self' instead of 'identity'?

VC: First, let me make a general point. While there is a need for the philosopher to invent new words to designate novel conceptions, the philosopher depends on ordinary or everyday language. Peirce is explicit: as far as philosophy goes, a twofold vocabulary is necessary: (1) a technical vocabulary deliberately and systematically crafted for specific 
purposes of inquiry, in addition to (2) everyday words. Now the specific point. CSP used the word God rather than the Absolute or some other technical equivalent. So, too, he used the word self. I am not being sloppy or careless in using both subject and self though I should have been more explicit about this. While these terms are hardly identical in meaning, their significance does overlap. Identity is too general a word (a rock has an identity but not a self). Self-identity is only one type or species of identity. For certain purposes, however, someone might add identity to the mix of self and subject. But that theorist would have to give a rationale. "The case of philosophy is very peculiar in that it[philosophy] has positive need of popular words in their popular sense, - not as its own language ... but as objects ion its study" (Essential Pierce, volume 2, 264-65). I take this to encompass the popular or everyday word self in one or more its commonplace meanings. 
APÊNDICE B - Tabela geral de perfis de coaches 


\begin{tabular}{|c|c|c|c|c|}
\hline 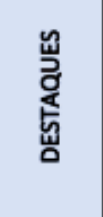 & 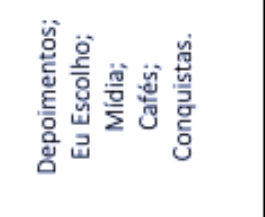 & 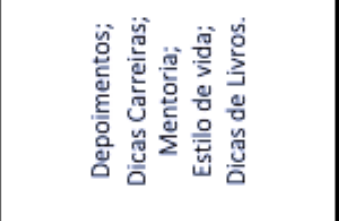 & ' & 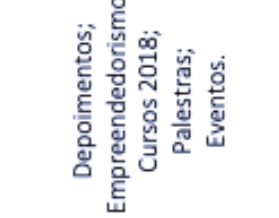 \\
\hline 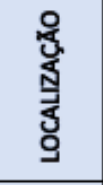 & " & ' & ' & 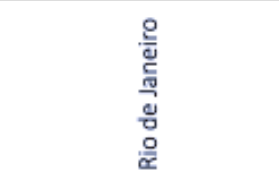 \\
\hline 喤 & 离 & خ্خ & 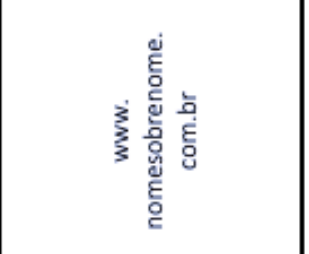 & 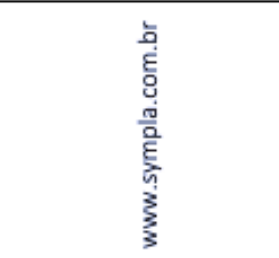 \\
\hline 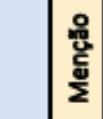 & ' & ' & ' & ' \\
\hline 言 & 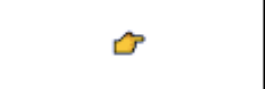 & 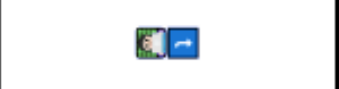 & DD & 맘 \\
\hline 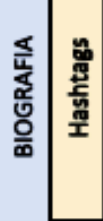 & 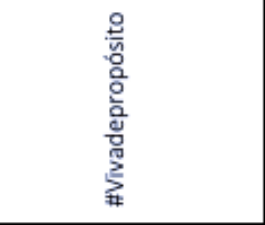 & ' & ' & ' \\
\hline 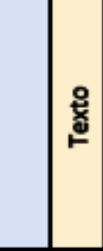 & 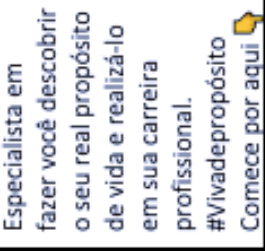 & 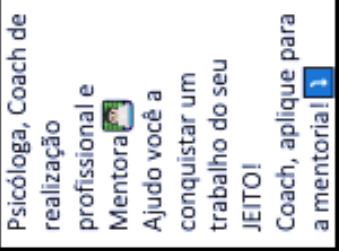 & 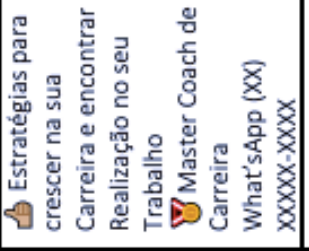 & 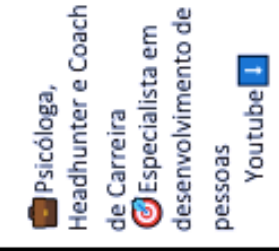 \\
\hline $\begin{array}{l}\frac{5}{\tilde{g}} \\
\text { 岁 } \\
\text { 岁 }\end{array}$ & 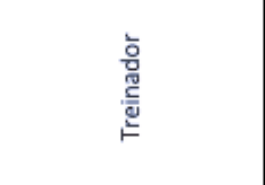 & 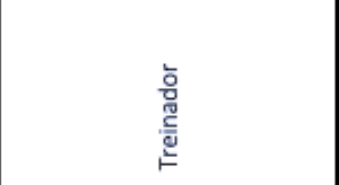 & 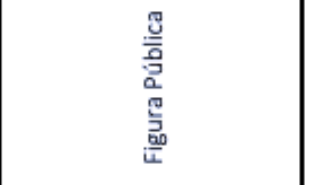 & 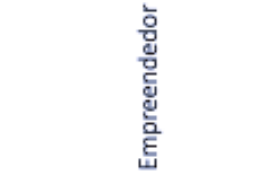 \\
\hline $\begin{array}{l}\text { Uू } \\
\text { Oे }\end{array}$ & 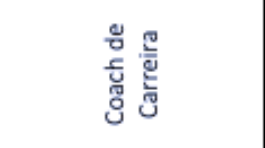 & 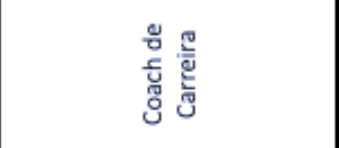 & 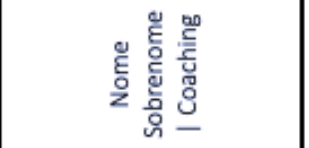 & है हूँ \\
\hline 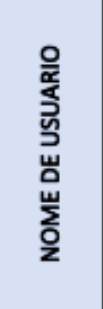 & 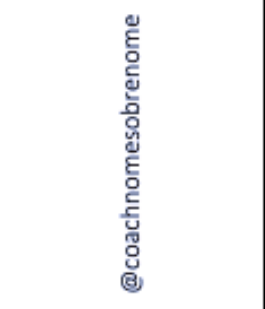 & 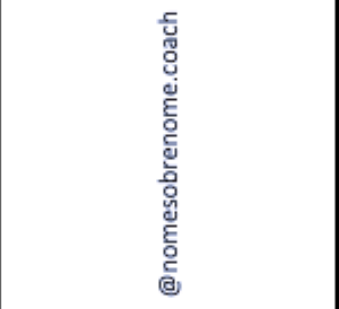 & 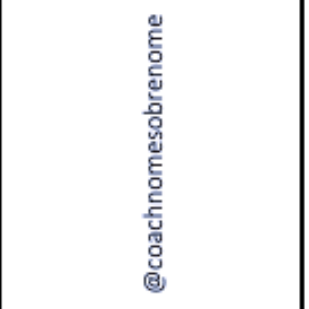 & 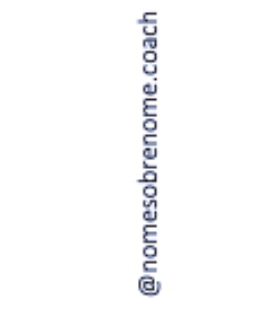 \\
\hline 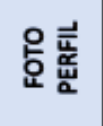 & 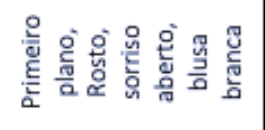 & 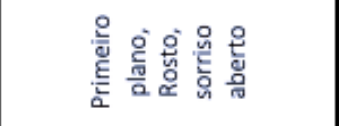 & 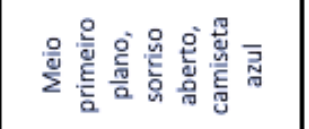 & 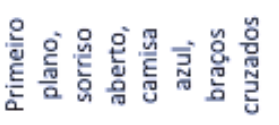 \\
\hline $\begin{array}{l}\text { I } \\
\text { d্ }\end{array}$ & $\frac{\pi}{4}$ & $\frac{10}{\bar{\alpha}}$ & 응 & $\stackrel{\frac{\pi}{3}}{0}$ \\
\hline
\end{tabular}




\begin{tabular}{|c|c|c|}
\hline 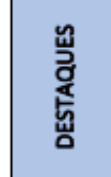 & 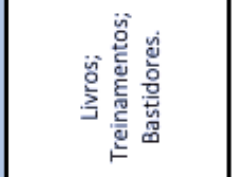 & 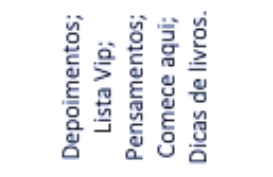 \\
\hline 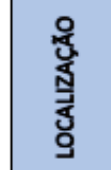 & ' & ' \\
\hline 峒 & 这 & 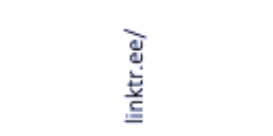 \\
\hline 遮 & ' & . \\
\hline '⿳亠丷厂二 & 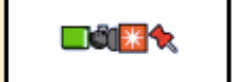 & 2000 \\
\hline 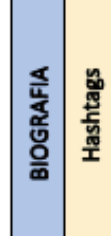 & 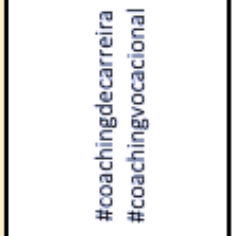 & . \\
\hline ช̊ & 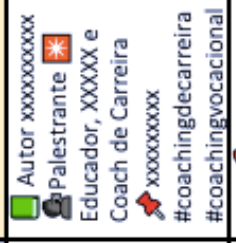 & 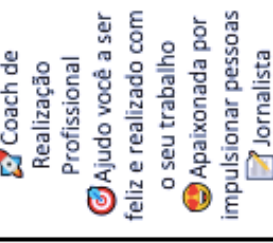 \\
\hline 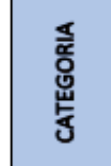 & 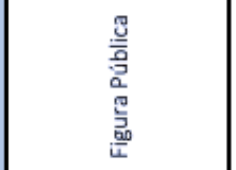 & 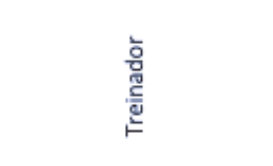 \\
\hline 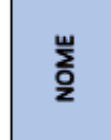 & 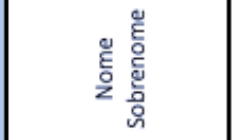 & 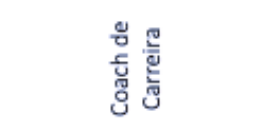 \\
\hline 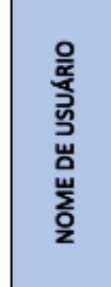 & 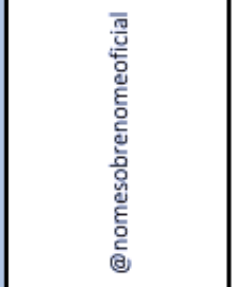 & 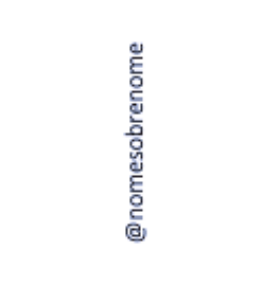 \\
\hline $\begin{array}{l}\text { 岁差 } \\
\text { 은 }\end{array}$ & 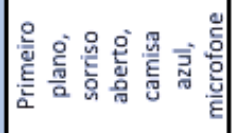 & 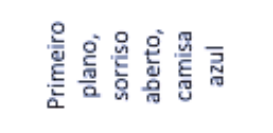 \\
\hline $\begin{array}{l}\text { İ } \\
\text { ğ }\end{array}$ & 可 & 営 \\
\hline
\end{tabular}

